AUTARQUIA ASSOCIADA À UNIVERSIDADE DE SÃO PAULO

INCORPORAÇÃO DE RADIONUCLÍDEOS EM NANOTUBOS NATURAIS ATIVADOS

JOSÉ PARRA SILVA

Dissertação apresentada como parte dos requisitos para obtenção do Grau de Mestre em Ciências na Área de Tecnologia Nuclear - Materiais

Orientadora:

Profa. Dra. Sonia Regina Homem de Mello Castanho 
INSTITUTO DE PESQUISAS ENERGÉTICAS E NUCLEARES

Autarquia associada à Universidade de São Paulo

INCORPORAÇÃO DE RADIONUCLÍDEOS EM NANOTUBOS NATURAIS ATIVADOS

JOSÉ PARRA SILVA

Dissertação apresentada como parte dos requisitos para obtenção do Grau de Mestre em Ciências na Área de Tecnologia Nuclear - Materiais

Orientadora:

Profa. Dra. Sonia Regina Homem de Mello Castanho

Versão Corrigida

Versão Original disponível no IPEN

São Paulo

2016 


\section{DEDICATÓRIA}

Dedico este trabalho a todas as pessoas que conheci ao longo desta caminhada, as pessoas que acreditaram em mim, as que me motivaram, as que me ensinaram e as que me ajudaram e contribuíram para minha formação como ser humano, a seguir:

In memoriam do meu avô Etelvino que nunca conheci, mas hoje estou aqui em certa medida para continuar aquilo que sempre escutei sobre ele, a paixão para criar e inventar, que minha mãe me transmitiu.

In memoriam da minha avó Rogélia que sempre me deu todo de coração, com carinho e amor.

À meu avô Alonso por me ensinar que a vida é uma luta pelos sonhos e que tem que ser perseverante e dedicado para ter aquilo que você deseja, deixando todo se for necessário para poder dar um futuro à família.

À minha avó Carmen pelo carinho, amor e fortaleza que sempre me transmite, e por sempre me conduzir pelo caminho da felicidade e da paz.

Aos meus pais, José e Estrella, por me acompanhar, orientar, fortalecer, ensinar, formar e pela liberdade que sempre me deram, por todas as conversações desde a distância, por todos os bons momentos que tivemos e teremos, e pela vida.

À minha irmã Carmen pelo carinho e pelos bons momentos e vivencias que me brindou e me brinda, assim como pelas sugestões e dicas relacionadas com a vida e com o desenvolvimento profissional.

À minha linda, cativante, forte e dedica namorada Fernanda pelo carinho, respeito, comprometimento, compreensão e amor.

In memoriam de meus tios e amigos que foram para um lugar melhor e deixaram comigo a melhor das mensagens; viver, viver, viver e viver, viver ao máximo e me aventurar por todos os que já não podem, porque um dia tudo termina. Entre eles meu querido tio Toño e meu querido tio Jaime, e meus amigos Javier Galán e Juan Osorio. 


\section{AGRADECIMENTOS}

À minha orientadora Dra. Sonia R.H. Mello Castanho, pela oportunidade de realizar este mestrado, orientação, confiança e consideração durante estes anos.

À Dra. Arisbel Serpa da Univerdad Europea de Madrid (UEM) pela confiança, oportunidade, preocupação e consideração, e por ser a principal responsável de que eu esteja hoje aqui, por tudo isso estarei sempre eternamente agradecido.

Ao Dr. Antônio Carlos da Silva (AC) pela amizade, orientação, consideração e força, ao dedicar parte do seu tempo para me ajudar durante grande parte do desenvolvimento deste trabalho e sobretudo por me transmitir o amor pela pesquisa.

À Dra. Chieko Yagamata pelo comprometimento, paciência, apoio, motivação, respeito e pela atitude, durante o desenvolvimento desta dissertação.

Ao Dr. Antonio Carlos Vieira-Coelho por me transmitir o seu conhecimento e carinho pela pesquisa e pelos argilominerais, pelas caracterizações e por dedicar o seu tempo para contribuir com este trabalho.

Ao Dr. Egilberto Galego e à Dra. Marilene Serna, do Laboratório de Células Fotovoltaicas do CCTM, pelo apoio, consideração e pela grande ajuda desde a etapa de caracterização até o desenvolvimento final deste trabalho.

Ao Dr. Walter Kenji pelo apoio e consideração, e por contribuir com esta pesquisa com as análises térmicas, assim como pela gentileza de disponibilizar o laboratório de Insumos para poder desenvolver grande parte deste trabalho.

Ao Mrs. René Ramos técnico e a Tec ${ }^{a}$. Gleicy Xavier do laboratório de Difração de Raios - X do CCTM pela disposição e pela contribuição com esta pesquisa.

Aos professionais do laboratório de Microscopia Eletrônica do CCTM, a Dra. Larissa Otubo, a Dra. Ana Lúcia E. Godoy, o técnico Nildemar A.M. Ferreira e o técnico Celso Vieira Morais pela agilidade na caracterização microestrutural de algumas amostras, pelo trato e pelo respeito.

À Dra. Maria das Graça da Silva Valenzuela do departamento de Engenharia Metalúrgica e Materiais (PMT) da USP, pela contribuição com esta pesquisa com a análise de capacidade de troca catiônica, pelo respeito e pela consideração. 
À Dra. Marycel E. B. Cotrim, do Laboratório de Análises Químicas e Ambiental do CQMA, pela disposição e agilidade na análise química das amostras finais.

Ao Dr. Silas Cardoso e o Dr. Thomaz Augusto pelo respeito e consideração mostrados ao longo desta pesquisa, e pela ajuda na etapa de caracterização.

Ao Bel. David H. Mello Castanho, pela amizade e consideração mostrados e pela ajuda com as aulas de química fornecidas na etapa inicial deste trabalho.

Ao Dr. José Claudio Dellamano, do centro de Gerencia de Rejeito Radioativo, pela disposição para ajudar e conversar, e pelo respeito e consideração.

Ao Dr. José Mario Prison por me ensinar aquilo que não está nos livros e estar sempre disposto a ajudar para desenvolver e melhorar este trabalho.

Ao Dr. Wilson Acchar da Universidade Federal do Rio Grande do Norte (UFRN) pela gentileza de contribuir com o material de partida, a paligorsquita.

Aos colaboradores da biblioteca do IPEN Terezine Arantes Ferraz pela atenção, educação e auxilio em todas minhas solicitações.

Aos professionais do IPEN dos seguintes centros de pesquisa: Gerencia de Rejeitos Radioativos (GRR), Química e Meio Ambiente (CQMA) e Ciência e Tecnologia dos Materiais (CCTM), pela gentileza em me receber nos respectivos laboratórios e auxilio na caracterização das amostras para o desenvolvimento desta dissertação.

Ao Instituto de Pesquisas Energéticas e Nucleares (IPEN) pela oportunidade deste maestrado.

À Coordenação de Aperfeiçoamento de Pessoal de Nível Superior (CAPES) e a Eletronuclear pelo apoio financeiro durante o meu mestrado.

À todos os colaboradores do IPEN que sempre me trataram com muita atenção e respeito.

À minha namorada Fernanda por me aportar tudo o que eu preciso para ser feliz.

À minha família, pelo amor, dedicação, acompanhamento, por me incentivar a ser sempre melhor e por me ensinar a acreditar em mim desde o início da minha vida. 


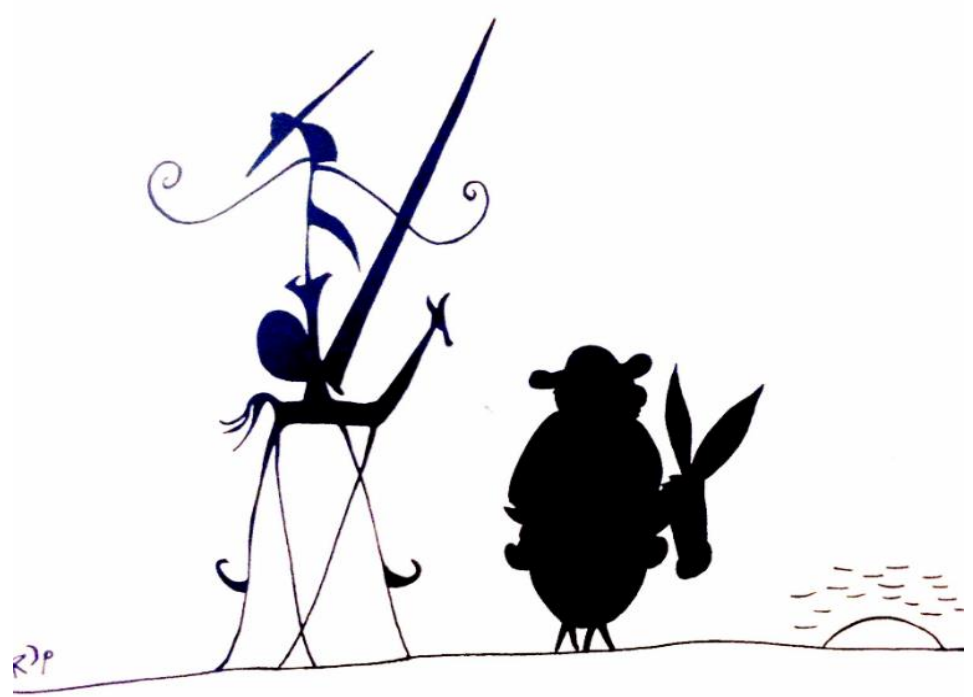

"A liberdade, Sancho, é um dos mais preciosos dons que aos homens deram os céus; a ela não se pode igualar os tesouros que encerram a terra e o mar: pela liberdade, assim como pela honra, se pode e se deve aventurar a vida" (DQ.II.58) 


\title{
INCORPORACÃO DE RADIONUCLÍDEOS EM NANOTUBOS NATURAIS ATIVADOS
}

\author{
José Parra Silva
}

\section{RESUMO}

Os nanotubos naturais da paligorsquita, por apresentarem propriedades físicas e químicas específicas, têm potencial uso como nano sorventes e matrizes para imobilização, retenção, e solidificação de radionuclídeos presentes em efluentes nucleares. No processo de desenvolvimento de materiais com propriedades de sorção visando a incorporação e imobilização de radionuclídeos, as etapas mais importantes são a geração de sítios ativos simultaneamente com o aumento da área superficial específica e tratamento térmico adequado para conduzir ao colapso estrutural. Neste estudo foram avaliados parâmetros e condições determinantes no processo de ativação dos nanotubos naturais da paligorsquita visando a sorção de radionuclídeos de interesse na estrutura dos nanotubos e a avaliação posterior dos parâmetros que afeitam ao colapso estrutural por tratamento térmico. Por este estudo constatou-se que a otimização do processo de ativação ácida é fundamental para o aumento da capacidade de sorção de níquel usando estruturas de nanotubos naturais ativados. A condição otimizada de ativação superficial, mantendo a integridade estrutural foi removido cerca de 33,3\% dos cátions de magnésio, equivalente a $6,30 \cdot 10^{-4} \mathrm{~mol} \cdot \mathrm{g}^{-1}$ de magnésio em massa, aumentando a área superficial específica em $42,8 \%$. Este aspecto permitiu a incorporação de mesma concentração molar de níquel presente nos rejeitos radioativos líquidos em um tempo de processo de $80 \mathrm{~min}$.

Palavras chave: Paligorsquita, nanotubos naturais ativados, ativação ácida, colapso estrutural, sorção, imobilização, radionuclídeos, rejeito nuclear. 


\title{
RADIONUCLIDES INCORPORATION IN ACTIVATED NATURAL NANOTUBES
}

\author{
José Parra Silva
}

\begin{abstract}
Natural palygorskite nanotubes show suitable physical and chemical properties and characteristics to be use as potential nanosorbent and immobilization matrix for the concentration and solidification of radionuclides present in nuclear wastes. In the development process of materials with sorption properties for the incorporation and subsequent immobilization of radionuclides, the most important steps are related with the generation of active sites simultaneously to the increase of the specific surface area and suitable heat treatment to producing the structural folding. This study evaluated the determining parameters and conditions for the activation process of the natural palygorskite nanotubes aiming at the sorption of radionuclides in the nanotubes structure and subsequent evaluation of the parameters involve in the structural folding by heat treatments. The optimized results about the maximum sorption capacity of nickel in activated natural nanotubes show that these structures are apt and suitable for incorporation of radionuclides similar to nickel. By this study is verified that the optimization of the acid activation process is fundamental to improve the sorption's capacities for specifics radionuclides by activated natural nanotubes. Acid activation condition optimized maintaining structural integrity was able to remove around $33.3 \mathrm{wt}$. \% of magnesium cations, equivalent to $6.30 \cdot 10^{-4}$ $\mathrm{g} \cdot \mathrm{mol}^{-1}$, increasing in $42.8 \%$ the specific surface area and incorporating the same molar concentration of nickel present in the liquid radioactive waste at $80 \mathrm{~min}$.
\end{abstract}

Key words: Palygorskite, activated natural nanotubes, acid activation, structural folding, sorption, immobilization, radionuclides, nuclear waste. 


\section{SUMÁRIO}

PÁGINA

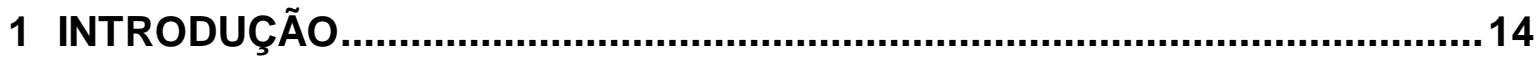

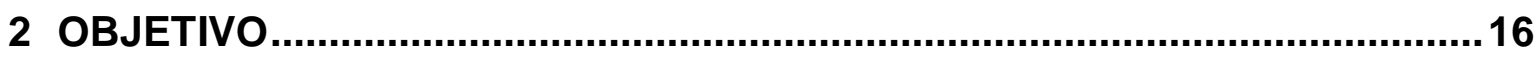

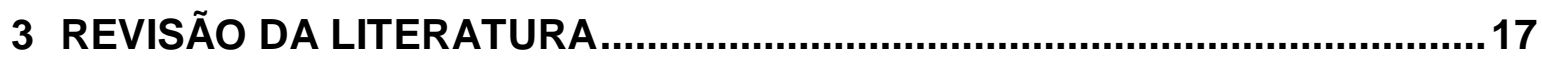

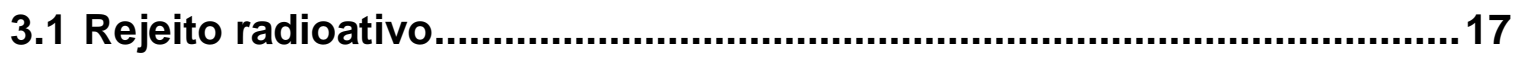

3.1.1 Gestão de rejeitos radioativos ................................................... 17

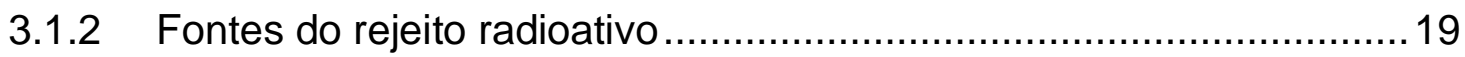

3.1.3 Fontes do rejeito radioativo líquido .............................................. 19

3.1.4 Tratamento do rejeito radioativo líquido .........................................21

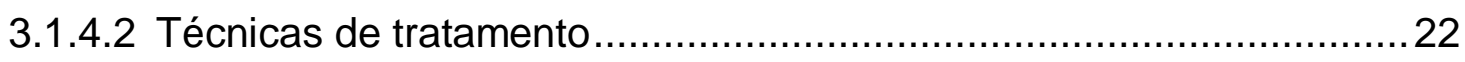

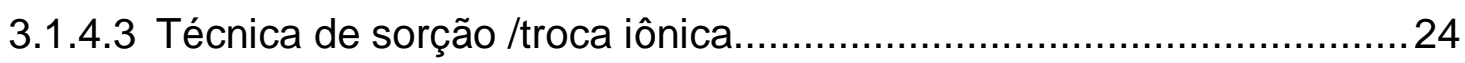

3.1.5 Passado, presente e futuro dos materiais usados no tratamento por

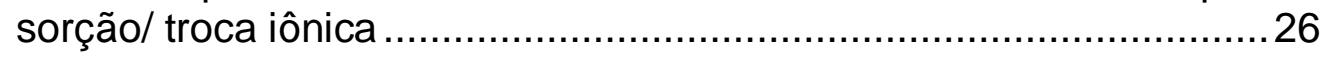

3.1.6 Proposta e motivação do uso de nanotubos naturais ativados para

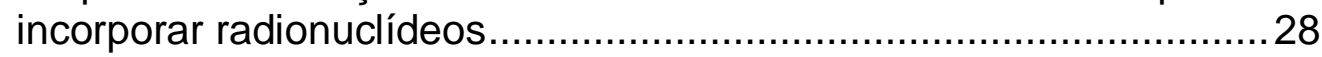

3.2 Seleção dos cátions procedentes do rejeito radioativo …........................30

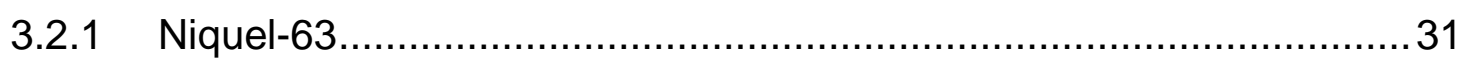

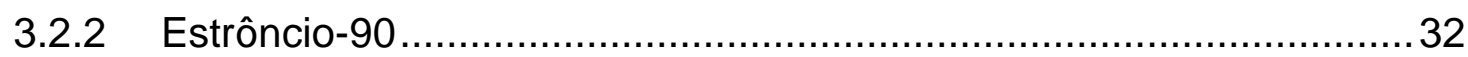

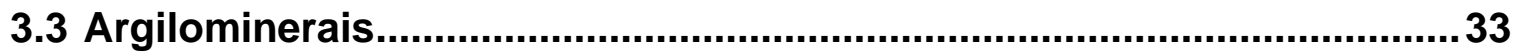

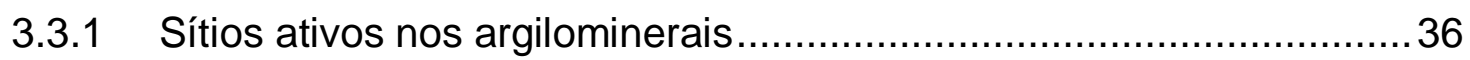

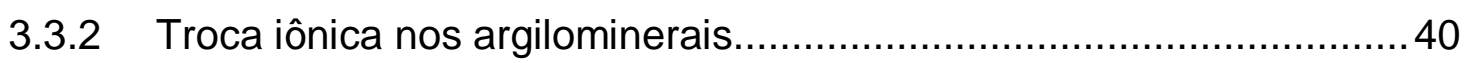

3.3.3 Efeitos da radiação nos argilominerais ......................................... 42

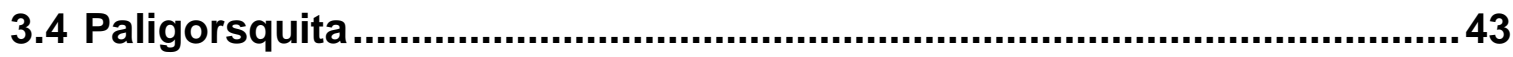

3.4.1 Efeitos da radiação na paligorsquita ........................................... 51

3.5 Mecanismo de incorporação e imobilização dos cátions .........................51

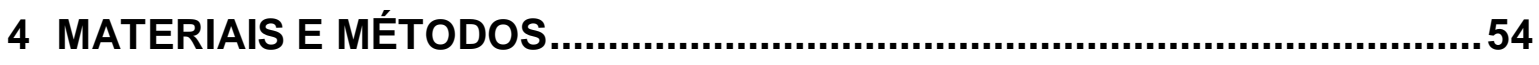

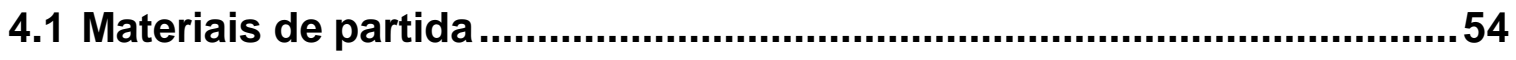

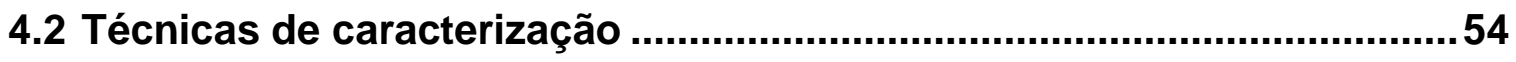

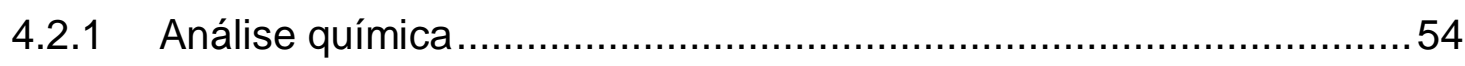


4.2.2 Distribuição granulométrica por espalhamento de Feixe de Laser.....55

4.2.3 Área superficial específica (BET), área e volume dos microporos e parâmetros físicos relacionados...............................................56

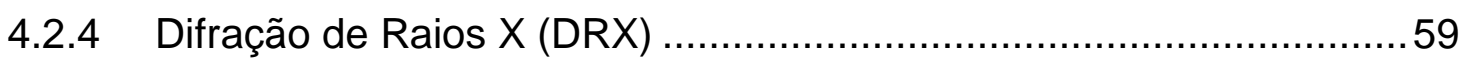

4.2.5 Análise Térmica Diferencial e Termo Gravimétrica (ATD/TG)............59

4.2.6 Espectroscopia no infravermelho com Transformada de Fourier (FTIR)

4.2.7 Capacidade de troca catiônica (CTC) ............................................ 61

4.2.8 Microscopia Eletrônica de Varredura (MEV) ...................................62

4.2.9 Microscopia Eletrônica de Transmissão com detector de Espectroscopia de Energia Dispersa (MET-EDS).

4.3 Processo de Incorporação de Radionuclídeos em Nanotubos Naturais Ativados 63

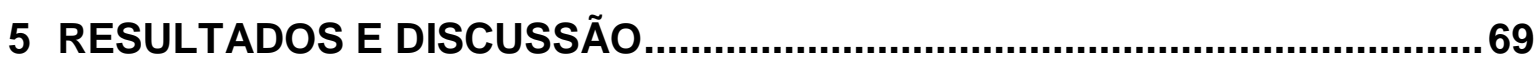

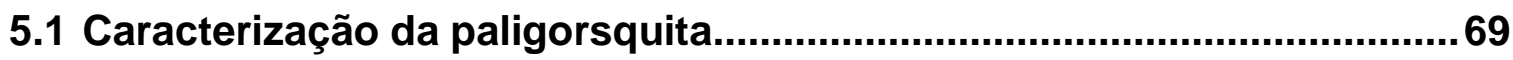

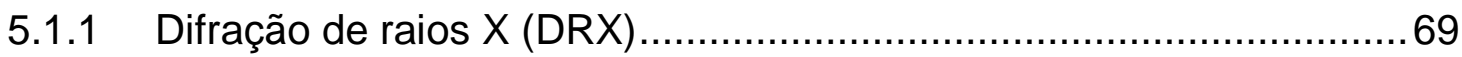

5.1.2 Fluorescência de raios $X$ com dispersão de energia (FRX-EDS).......71

5.1.3 Espectroscopia de absorção na região do infravermelho (FT-IR) ......72

5.1 .4 Distribuição granulométrica................................................. 74

5.1.5 Área superficial específica (BET), área e volume dos microporos e parâmetros físicos relacionados................................................ 74

5.1.6 Microscopia eletrônica de varredura (MEV) ...............................76

5.1.7 Capacidade de troca catiônica (CTC) ...................................... 76

5.1.8 Análise térmica diferencial e termogravimétrica (ATD/TG) ..............76

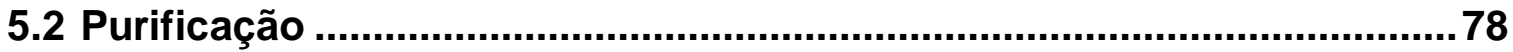

5.3 Otimização do processo de colapso estrutural por tratamento térmico dos nanotubos naturais

5.4 Otimização do processo de ativação ácida dos nanotubos naturais ....92

5.5 Incorporação de radionuclídeos em nanotubos naturais ativados...... 110

6 CONCLUSÕES............................................................................................ 117

7 REFERENCIAS BIBLIOGRAFICAS ....................................................... 118 


\section{ÍNDICE DE FIGURAS}

PÁGINA

FIGURA 1 - Fluxograma das etapas de gestão de rejeitos radioativos.................17

FIGURA 2 - Fontes dos Rejeitos Radioativos. ............................................ 19

FIGURA 3 - Esquema do tratamento do Rejeito Radioativo. ...............................22

FIGURA 4 - Publicações relevantes por país nas áreas de materiais e técnicas de tratamento de rejeito radioativo liquido $(R R L)$ desde 2014 - Presente..................24

FIGURA 5 - Representação esquemática dos nanotubos naturais, dos canais externos da estrutura e da célula unitária da paligorsquita...............................29

FIGURA 6 - Número de publicações científicas realizadas utilizando paligorsquita.

FIGURA 7 - Representação de: (a) tetraedro de silício, (b) folha tetraédrica, (c) octaedro de magnésio ou alumínio e (d) folha octaédrica..................................34

FIGURA 8 - Sítios ativos dos argilominerais 2:1: superfície dos grupos siloxanos.

FIGURA 9 - Sítios ativos dos argilominerais: Cátions metálicos trocáveis e cátions estruturais expostos contendo esfera de coordenação insaturada.

FIGURA 10 - Sítios ativos dos argilominerais: moléculas de água polarizadas ao redor de cátions trocáveis e cátions nas arestas. 38

FIGURA 11 - Sítios ativos dos argilominerais: Sítios hidrofóbico. 39

FIGURA 12 - Sítios ativos dos argilominerais: Grupo silanol e aluminol...... 39

FIGURA 13 - Raio iônico $(R)$ Vs raio iônico hidratado $\left(R_{H}\right)$.

FIGURA 14 - a) Estrutura da paligorsquita (duas células unitárias) projetada no plano (001) e b) disposição octaédrica.

FIGURA 15 - Esquema do colapso ou "folding" estrutural da paligorsquita durante

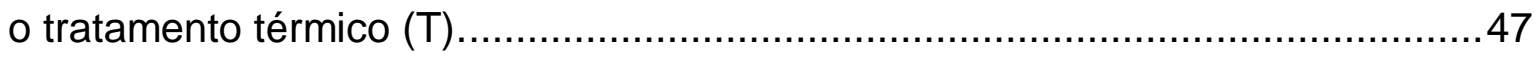

FIGURA 16 - Localização dos grupos silanol na paligorsquita. ........................48

FIGURA 17 - Caráter anfótero do grupo silanol. ........................................53 
FIGURA 18 - Representação do cálculo do volume e área do microporo e da área externa da paligorsquita purificada (PP) pelo método "t - plot" baseado na equação de Harkins e Jura (H-J).

FIGURA 19 - Distribuição da espécie $\mathrm{Ni}^{2+}$ (a) e $\mathrm{Sr}^{2+}$ (b) em função do $\mathrm{pH}$ 67

FIGURA 20 - Fluxograma do processo de incorporação de radionuclídeos nos nanotubos naturais ativados de paligorsquita.

FIGURA 21 - Difratograma de Raios X da paligorsquita como recebida (PN). .....69

FIGURA 22 - Espectro infravermelho da paligorsquita como recebida.

FIGURA 23 - Curva de distribuição de tamanho de partículas a partir de uma amostra de paligorsquita como recebida (PN).

FIGURA 24 - Isoterma de adsorção-dessorção de $\mathrm{N}_{2}$ da paligorsquita como recebida (PN)

FIGURA 25 - Micrografias da paligorsquita como recebida (PN) obtidas por microscopia eletrônica de varredura (MEV).

FIGURA 26 - Análises Termogravimétrico (ATG) e Termodiferencial (ATD) da paligorsquita como recebida.

FIGURA 27 - Difratogramas da paligorsquita como recebida (PN) e purificada (PP).

FIGURA 28 - Espectrogramas da paligorsquita como recebida (PN) e purificada (PP).

FIGURA 29 - Análises Termogravimétrico (ATG) e Termodiferencial (ATD) da

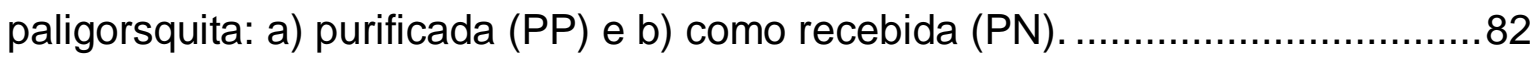

FIGURA 30 - Isotermas de adsorção (ADS) - dessorção (DES) de $\mathrm{N}_{2}$ da paligorsquita como recebida (PN) e purificada (PN) .......................................... 83

FIGURA 31 - Micrografias obtidas por MEV da amostra de paligorsquita (a) como recebida $(\mathrm{PN})$ e (b) purificada $(\mathrm{PP})$.

FIGURA 32 - Micrografias por microscopia eletrônica de transmissão da amostra de paligorsquita purificada (PP).

FIGURA 33 - Difração de raios $X$ das amostras de paligorsquita tratadas termicamente (P300, P550 e P800) e a purificada (PP).

FIGURA 34 - Espectro Infravermelho da paligorsquita purificada (PP) e das amostras tratadas termicamente (P300, P550, P800).

FIGURA 35 - Evolução da área superficial especifica (a) e volume do microporo (b) das amostras tratadas termicamente. 
FIGURA 37 - Fração de cátions de magnésio $\left(\mathrm{Mg}^{2+}\right)$ removidos da paligorsquita purificada no processo de ativação em função do tempo e da concentração de ácido para cada temperatura a) $60^{\circ} \mathrm{C}$ e b) $90^{\circ} \mathrm{C}$. 96

FIGURA 38 - Percentagens normalizados dos cátions de magnésio $(\mathrm{Mg})$, ferro $(\mathrm{Fe})$ e alumínio (Al) removidos para cada condição de ativação.

FIGURA 39 - Difratogramas de: a) amostra purificada (PP) e das amostras ativadas em função da remoção dos cátions de magnésio b) P9, c) P13, d) P2, e) P14, f) P12 e g) P16.

FIGURA 40 - Espectrogramas de número de onda altos: a) amostra purificada (PP) e das amostras ativadas em função da lixiviação dos cátions de magnésio b) P9, c) $\mathrm{P} 13$, d) P2, e) P14, f) P12 e g) P16. 102

FIGURA 41 - Espectrogramas de baixo número de onda: a) amostra purificada (PP) e das amostras ativadas em função da lixiviação dos cátions de magnésio b) P9, c) P13, d) P2, e) P14, f) P12 e g) P16. 103

FIGURA 42 - Isotermas de adsorção-dessorção de $\mathrm{N}_{2}$ da paligorsquita purificada (PP) e das amostras ativadas (P9, P13, P2, P14, P12 e P16). 105

FIGURA 43 - a) Área calculada relativa aos microporos e b) Volume calculado dos microporos da amostra purificada (PP) e das amostras ativadas P9, P13, P2, P14, P12 e P16. 107

FIGURA 44 - Micrografias da paligorsquita purificada (PP) "a" e da paligorsquita ativada (P2) "b". 108

FIGURA 45 - Micrografias por Microscopia Eletrônica de Transmissão dos nanotubos naturais da paligorsquita a) purificada PP e b) ativada na condição P2.

FIGURA 46 - Capacidade de sorção dos cátions de níquel na paligorsquita ativada em função do tempo (ICP).

FIGURA 47 - Capacidade de sorção dos cátions de estrôncio na paligorsquita ativada em função do tempo (ICP).

FIGURA 48 - Difratograma das amostras de paligorsquita a) purificada (PP), b) com níquel (PA-Ni) e c) com níquel tratada a 550ํㅡ (PNi-550) ................................113

FIGURA 49 - MET com EDS da paligorsquita ativada com níquel (PNi) ............114

FIGURA 50 - Micrografias por MET da amostra PA-Ni tratada termicamente em a) atmosfera ao $\mathrm{Ar}$ e b) atmosfera redutora, nas condições otimizadas 115

FIGURA 51 - Micrografias com MET e microanálise (EDS) dos nanotubos ativados com níquel incorporado tratada termicamente em atmosfera redutora $\left(\mathrm{H}_{2} / \mathrm{Ar}\right)(\mathrm{PA}$ Ni550r). 


\section{ÍNDICE DE TABELAS}

PÁGINA

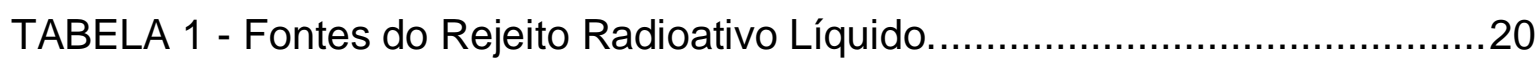

TABELA 2 - Radionuclídeos presentes em Rejeitos Radioativos Líquidos de

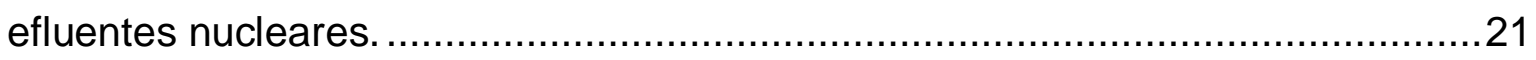

TABELA 3 - Aplicações, características e limitações mais significativas das principais técnicas empregadas no tratamento de Rejeitos Radioativos Líquidos.

TABELA 4 - Propriedades radioativas dos principais isótopos radioativos do Níquel..

TABELA 5 - Propriedades radioativas do estrôncio e do radionuclídeo associado no decaimento. 32

TABELA 6 - Classificação dos argilominerais. 35

TABELA 7 - Carga iônica, raio iônico, potencial iônico, eletronegatividade e raio hidratado dos cátions de magnésio $\left(\mathrm{Mg}^{2+}\right)$, níquel $\left(\mathrm{Ni}^{2+}\right)$ e estrôncio $\left(\mathrm{Sr}^{2+}\right)$.

TABELA 8 - Bandas de adsorção e dos modos de vibração característicos da paligorsquita identificados na literatura 60

TABELA 9 - Condições experimentais de ativação ácida da paligorsquita. 66

TABELA 10 - Principais reflexões da ficha ICDD - 031 - 0783 usada para identificar as reflexões da paligorsquita na amostra de paligorsquita como recebida .70

TABELA 11 - Principais reflexões da ficha ICDD - 065 - 0466 usada para identificar as reflexões do quartzo na amostra de paligorsquita como recebida.

TABELA 12 - Principais reflexões da ficha ICDD - 084 - 1208 usada para identificar as reflexões da dolomita na amostra de paligorsquita como recebida. .70

TABELA 13 - Resultados da análise por Fluorescência de Raios-X por dispersão de energia (EDS) da paligorsquita (PN).

TABELA 14 - Identificação das bandas de adsorção e dos modos de vibração característicos da paligorsquita como recebida (PN)

TABELA 15 - Área superficial específica, área e volume dos microporos e parâmetros físicos relacionados da paligorsquita como recebida (PN). .75

TABELA 16 - Principais reflexões identificadas na ficha ICDD -031-0788 e comparação das reflexões da paligorsquita como recebida (PN) com as reflexões da paligorsquita purificada (PP). 
TABELA 17 - Resultados da análise por FRX-EDS da paligorsquita como recebida (PN) e a purificada (PP).

TABELA 18 - Área superficial especifica, área e volume dos microporos e parâmetros físicos relacionados da paligorsquita como recebida $(P N)$ e purificada (PP).

TABELA 19 - Área superficial específica e área e volume dos microporos das amostras tratadas termicamente e da amostra purificada. 90

TABELA 20 - Condição otimizada de colapso estrutural por tratamento térmico.. 91

TABELA 21 - Resultados das análises químicas (FRX-EDS) da amostra como recebida, purificada e ativadas em diferentes condições de $\mathrm{CM}=$ concentração molar $\left(\mathrm{mol}^{\left.-\mathrm{L}^{-1}\right)}, \mathrm{T}=\right.$ temperatura $\left({ }^{\circ} \mathrm{C}\right)$ e $\mathrm{t}=$ tempo $(\mathrm{h})$

TABELA 22 - Fator de normalização $\left(F_{N}\right)$ e percentagens normalizados dos cátions de magnésio $\left(\mathrm{Mg}_{\mathrm{N}}\right)$, ferro $\left(\mathrm{Fe}_{\mathrm{N}}\right)$ e alumínio $\left(\mathrm{A} \mathrm{I}_{\mathrm{N}}\right)$ removidos para cada condição.. 95

TABELA 23 - Melhores resultados para cada região escolhida de remoção dos cátions de magnésio e percentagens em massa lixiviado da paligorsquita. 98

TABELA 24 - Principais reflexões identificadas na ficha ICDD - $031-0783$ e comparação das reflexões da paligorsquita purificada (PP) com as reflexões da paligorsquita das amostras ativadas (P9, P13, P2, P14, P12 e P16).................100

TABELA 25 - Área superficial específica, área e volume dos microporos e parâmetros físicos relacionados da amostra purificada e as ativadas nas diferentes condições 106

TABELA 26 - Condição otimizada de ativação superficial dos nanotubos naturais. 109

TABELA 27 - Concentrações de $\mathrm{Ni}^{2+} \mathrm{e} \mathrm{Sr}^{2+}$ previstas e calculadas para substituir o $\mathrm{Mg}^{2+}$ lixiviado, determinado na condição PA.

TABELA 28 - Fluorescência de Raios X por EDS das amostras de paligorsquita ativada com metal (PA-Ni e PA-Sr) e das amostras sem ativar (PP-Ni e PP-Sr). 


\section{INTRODUÇÃO}

O uso de radionuclídeos para fins pacíficos, como geração de energia elétrica, bem como a aplicação de radionuclídeos em diversas áreas, como na medicina, na indústria e no monitoramento ambiental, vem recebendo uma considerável expansão no Brasil e no mundo na última década. Paralelamente a estas atividades, o aumento do volume rejeitos radioativos é inevitável (FERREIRA, ALEIXO, et al., 2012).

Do setor nuclear, um dos aspectos mais importantes no impacto aos ecossistemas da Terra são os rejeitos radioativos que resultam das atividades nucleares. Os radionuclídeos presentes nestes permanecem ativos por milhares de anos e precisam, por isso, de rigoroso controle do descarte ou armazenagem. A gestão dos resíduos radioativos visa proteger as pessoas e os ecossistemas existentes.

Vários tipos de rejeitos são gerados e cada um requer tratamento específico. Os rejeitos líquidos que apresentam níveis de radiação maiores que os limites de isenção especificados (CNEN, 2014), requerem, necessariamente, de tratamento adequado antes de serem enviados para um repositório na forma física em que se encontram. Nesse caso, o tratamento visa a redução de volume, remoção de radionuclídeos e mudança de estado físico e químico, com custo mínimo e com máxima segurança.

$\mathrm{Na}$ literatura são descritos diversos métodos de tratamento de rejeitos radioativos líquidos, como filtração, precipitação, sorção/ troca iônica, evaporação e separação por membranas (RAHMAN, IBRAHIUM e HUNG, 2011).

O método de sorção/troca iônica é um dos mais populares e atrativos usados para o tratamento de efluentes contendo radionuclídeos e metais pesados.

Entre os materiais inorgânicos propostos para o tratamento por sorção/troca iônica, encontram-se diversos tipos de argilominerais, zeólitas, zeólitas sintéticas, carvão ativado, titânio-silicatos, fosfatos de zircônio e argilominerais pilarizados. 
As propriedades inerentes dos argilominerais torna-los quimicamente ativos e sorvedores. As características químicas peculiares, associadas a escala nanométrica da rede estrutural com a presença de nanotubos naturais, como é o caso da paligorsquita, faz com que ela seja uma potencial candidata para cumprir os requisitos de alta sensibilidade e seletividade na extração em meio sólido-líquido para a remoção de íons pesados ou radioativos, somado à excelente resistência ao ataque hidrolítico comparada com outros argilominerais (GALAN, 2011; ZHOU e KEELING, 2013; MURRAY, 2000).

Diferentes pesquisas relataram que o aumento dos sítios ativos e da área superficial específica mediante processos de ativação ácida, são fundamentais para aumentar a capacidade de sorção dos argilominerais fibrilares, como é o caso da paligorsquita e da sepiolita (HUSSIN, AROUA e DAUD, 2011; CHEN e WANG, 2009; ESTEBAN-CUBILLO, PINA-ZAPARDIEL, et al., 2008). No entanto, os processos de ativação observados para a paligorsquita foram pouco claros enquanto ao papel dos cátions de magnésio na estabilidade estrutural, e na incorporação de radionuclídeos na estrutura dos nanotubos ativados deste argilomineral. Devido à falta de informações sobre estes mecanismos, este trabalho selecionou este método para desenvolvimento das metas propostas.

Recentemente foi prospectado um depósito de paligorsquita no estado do Piauí no Brasil, com as reservas distribuídas por uma área aproximada de $700 \mathrm{~km}^{2}$, em corpos que alcançam mais de $500 \mathrm{~m}$ de comprimento e espessuras de até 17 m (LUZ e ALMEIDA, 2008). A exploração adequada desta jazida pode resultar em um desenvolvimento econômico importante para a região a qual justifica o interesse no desenvolvimento tecnológico de produtos com alto valor agregado a partir deste insumo argilomineral.

Na área nuclear não há relatos da utilização de paligorsquita como matriz de imobilização de radionuclídeos, mas foram observadas pesquisas visando a remoção de radionuclídeos de interesse presentes em efluentes nucleares (CHEN, GAO e LU, 2011). 


\section{OBJETIVO}

Desenvolver nanotubos naturais para uso na incorporação de radionuclídeos presentes em efluentes nucleares, a partir de paligorsquita nacional.

Otimizar o processo de ativação ácida visando o aumento de eficiência de sorção, preservando a integridade estrutural dos nanotubos para a incorporação e imobilização dos radionuclídeos. 


\section{REVISÃO DA LITERATURA}

\subsection{Rejeito radioativo}

Os materiais radioativos são resultados inevitáveis da fissão nuclear, assim como as cinzas e os dióxidos de carbono e de enxofre são inevitáveis na queima do carvão.

No Brasil, a Comissão Nacional de Energia Nuclear (CNEN, 2015), define rejeito radioativo como "qualquer material resultante das atividades humanas, que contenha radionuclídeos em quantidades superiores aos limites de isenção estabelecidos pela CNEN, e para o qual a reutilização é imprópria ou não prevista".

\subsubsection{Gestão de rejeitos radioativos}

Gestão de rejeitos radioativos é o conjunto de atividades operacionais e administrativas de controle visando minimizar os custos e as doses operacionais durante o seu manuseio, assim como proteger a saúde do homem e do meio ambiente, no presente e futuro, de modo a não impor ônus indevidos às gerações futuras (HIROMOTO, DELLAMANO, et al., 1999).

O fluxograma das etapas correspondentes à gestão de rejeitos radioativos é apresentado na FIG.1.

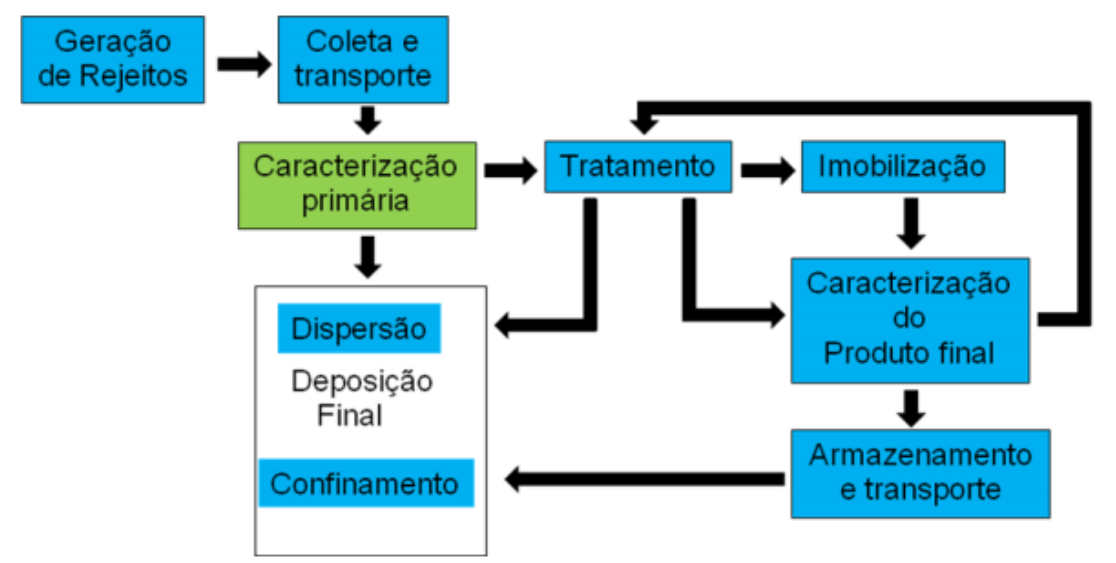

FIGURA 1 - Fluxograma das etapas de gestão de rejeitos radioativos. Fonte: (HIROMOTO, DELLAMANO, et al., 1999). 
No Brasil, os rejeitos radioativos classificam-se segundo a norma CNEN-NN 8.01 (CNEN, 2014) em:

- Classe 0: Rejeitos Isentos (RI). Nesta classe estão os rejeitos que possuem o valor de atividade, em massa ou volume, inferior aos respectivos níveis de dispensa que são apresentados na norma.

- Classe 1: Rejeitos de Meia-Vida Muito Curta (RVMC). Os rejeitos desta classe possuem a meia-vida inferior ou da ordem de 100 dias, apresentam o valor de atividade superior aos níveis de dispensa.

- Classe 2: Rejeitos de Baixos e Médios Níveis de Radiação (RBMN). Nesta classe estão os rejeitos com meia-vida superior aos da classe 1, e apresentam algumas subdivisões:

- Classe 2.1: Meia-Vida Curta (RBMN-VC). Nesta classe estão os rejeitos de baixo e médio níveis de radiação que contêm emissores do tipo beta ou gama, com meia-vida inferior ou da ordem de 30 anos. Incluem-se concentrações de radionuclídeos emissores alfa de meia-vida longa, estes são limitados a 3700 kBq/kg em volumes individuais e com um valor médio de $370 \mathrm{kBq} / \mathrm{kg}$ para o conjunto de volumes.

- Classe 2.2: Rejeitos Contendo Radionuclídeos Naturais (RBMN$R N)$. Esta classe inclui os rejeitos de extração e exploração de petróleo que contêm os radionuclídeos das séries do urânio e tório em concentrações de atividade ou atividades acima dos níveis de dispensa estabelecidos.

- Classe 2.3: Rejeitos contendo Radionuclídeos Naturais (RBMN-RN). Esta classe possui os rejeitos que contém as matérias primas minerais, naturais ou industrializadas, como os radionuclídeos das séries do urânio e do tório em concentrações de atividade ou atividades acima dos níveis de dispensa estabelecidos.

- Classe 2.4: Rejeitos de Meia-Vida Longa (RBMN-VL): os rejeitos que não foram enquadrados nas Classes 2.2 e 2.3 e nas concentrações de radionuclídeos de meia-vida longa que excedem as limitações para a classificação de rejeitos de meia-vida curta.

- Classe 3: Rejeitos de Alto Nível de Radiação (RAN). Esta classe inclui rejeitos de potência térmica superior a $2 \mathrm{~kW} / \mathrm{m}^{3}$ e cujas concentrações 
de radionuclídeos de meia-vida longa excedam as limitações para classificação como rejeitos de meia-vida curta.

\subsubsection{Fontes do rejeito radioativo}

Os rejeitos radioativos são provenientes de vários processos, como por exemplo, os materiais contaminados na operação de centrais nucleares, pára-raios radioativos fora de uso, fontes de radioterapia exauridas, materiais contaminados em atividades com fontes radioativas abertas, materiais radioativos utilizados para pesquisa e não reutilizáveis e materiais produzidos na indústria de combustíveis nucleares, desde a mineração à produção do elemento combustível (IAEA, 2013).

O rejeito nuclear tem sua origem a partir principalmente de três fontes, descritos na FIG.2 (OJOVAN e LEE, 2014):

- Ciclo de Combustível Nuclear (NFC) usado para a geração de energia elétrica e propósitos militares,

- Instituições não-NFC (indústrias não nucleares e instituições médicas e de pesquisa) e

- Resultantes de Acidentes.

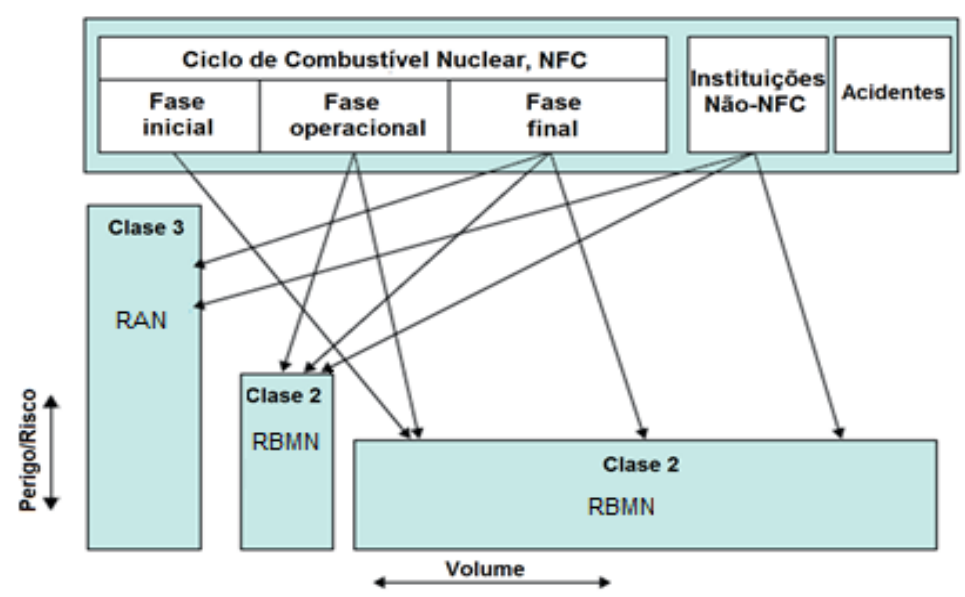

FIGURA 2 - Fontes dos Rejeitos Radioativos. Fonte: (OJOVAN e LEE, 2014).

\subsubsection{Fontes do rejeito radioativo líquido}

Os rejeitos radioativos líquidos são gerados durante as operações do reator nuclear, durante a aplicação de radioisótopos na indústria e nas diferentes instituições (medicina, pesquisa, etc.), assim como no descomissionamento de 
usinas nucleares. As composições químicas e os níveis de radioatividade dos rejeitos gerados dependem da fonte e da operação realizada, podendo variar amplamente o conteúdo para ambas. A maioria das operações também produzem uma grande variedade de rejeitos radioativos líquidos no local, tais como os procedentes de chuveiros, lavanderias e laboratórios analíticos, e de serviços de descontaminação (IAEA, 2001).

As principais fontes de rejeitos radioativos líquidos e as suas características estão apresentadas na TAB.1.

TABELA 1 - Fontes do Rejeito Radioativo Líquido.

\begin{tabular}{|c|c|c|}
\hline Fonte & Radioisótopos típicos & Características \\
\hline - Produção de energia & $\begin{array}{l}\text { - Ampla variedade de } \\
\text { radioisótopos de vida } \\
\text { curta e de vida longa }\end{array}$ & $\begin{array}{l}\text { - Volume grande com } \\
\text { composições químicas variáveis }\end{array}$ \\
\hline $\begin{array}{l}\text { - Centro de pesquisa } \\
\text { Nuclear }\end{array}$ & $\begin{array}{l}\text { - Pode incluir radioisótopos } \\
\text { de vida longa misturados } \\
\text { com os de vida curta }\end{array}$ & $\begin{array}{l}\text { - Geralmente lotes homogêneos } \\
\text { com valores de pH neutros para } \\
\text { a regeneração das resinas de } \\
\text { troca iônica }\end{array}$ \\
\hline $\begin{array}{l}\text { - Laboratórios de } \\
\text { produção de } \\
\text { radioisótopos }\end{array}$ & $\begin{array}{l}\text { - Grande variedade } \\
\text { dependendo do } \\
\text { laboratório de produção. }\end{array}$ & $\begin{array}{l}\text { - Pequenos volumes com alta } \\
\text { atividade específica e altas } \\
\text { concentrações químicas }\end{array}$ \\
\hline $\begin{array}{l}\text { - Raio marcação e } \\
\text { raio-farmácia }\end{array}$ & • 4C,3H, 32P, 35S, 125I & $\begin{array}{l}\text { - Grandes volumes de baixa } \\
\text { atividade específica }\end{array}$ \\
\hline $\begin{array}{l}\text { - Diagnóstico médico e } \\
\text { tratamento }\end{array}$ & - 99Tc, 131I, 85Sr & $\begin{array}{l}\text { - Grandes volumes da urina dos } \\
\text { pacientes }\end{array}$ \\
\hline $\begin{array}{l}\text { - Indústria e plantas } \\
\text { piloto }\end{array}$ & - Depende da aplicação & $\begin{array}{l}\text { - Os volumes podem ser grandes } \\
\text { com composições químicas } \\
\text { indefinidas }\end{array}$ \\
\hline $\begin{array}{l}\text { - Lavanderia e } \\
\text { descontaminação }\end{array}$ & - Ampla variedade & $\begin{array}{l}\text { - Grandes volumes com baixa } \\
\text { atividade específica contendo } \\
\text { agentes complexos. }\end{array}$ \\
\hline
\end{tabular}

Os radionuclídeos presentes nos rejeitos radioativos líquidos variam de um tipo de fonte para outra. No rejeito radioativo líquido podem-se encontrar radionuclídeos procedentes de produtos de fissão do combustível nuclear, produtos de ativação e produtos da transmutação de radionuclídeos ou trasurânicos (OJOVAN e LEE, 2014). Os principais radionuclídeos presentes nos efluentes de rejeitos radioativos líquidos das usinas nucleares procedentes do processo de 
fissão nuclear são apresentados na TAB.2 (SOUSA-REIS, TEMBA, et al., 2012; NIKIFOROVA, TASKAEVA, et al., 2005; DLOUHY, 1982; OJOVAN e LEE, 2014).

TABELA 2 - Radionuclídeos presentes em Rejeitos Radioativos Líquidos de efluentes nucleares.

\begin{tabular}{ccc}
\hline Produtos & Radionuclídeos & $\begin{array}{c}\text { Modo de } \\
\text { decaimento }\end{array}$ \\
\hline Produtos de fissão & ${ }^{90} \mathrm{Sr},{ }^{99} \mathrm{Tc},{ }^{137} \mathrm{Cs},{ }^{129} \mathrm{I}$, & $\beta$ \\
Produtos de ativação & ${ }^{134} \mathrm{Cs}$ & $\mathrm{Y}$ \\
& ${ }^{3} \mathrm{H},{ }^{14} \mathrm{C},{ }^{94} \mathrm{Nb},{ }^{60} \mathrm{Co},{ }^{63} \mathrm{Ni},{ }^{54} \mathrm{Mn},{ }^{55} \mathrm{Fe}$, & $\beta$ \\
Produtos trasurânicos / & ${ }^{59} \mathrm{Ni}$ & $\mathrm{EC}$ \\
radionuclídeos transmutados & ${ }^{242} \mathrm{Cm},{ }^{244} \mathrm{Cm},{ }^{235} \mathrm{U},{ }^{238} \mathrm{U},{ }^{239} \mathrm{Pu}$, & \\
& ${ }^{240} \mathrm{Pu},{ }^{241} \mathrm{Pu}$ & $\alpha$ \\
\hline
\end{tabular}

* EC=Captura de elétrons. Não ocorre emissão de radiação nuclear. No entanto, a captura do elétron provoca a emissão de raios $\mathrm{X}$ característicos.

\subsubsection{Tratamento do rejeito radioativo líquido}

\subsubsection{Objetivo do tratamento}

O tratamento de rejeitos radioativos primários incluem operações destinadas a beneficiar a segurança e a economia, alterando as características dos rejeitos, por meio de diferentes técnicas. Os três objetivos básicos de tratamento de rejeitos radioativos são (OJOVAN e LEE, 2014).

- Redução de volume,

- Remoção de radionuclídeos,

- Mudança de estado físico e composição química.

O fator de redução de volume de rejeitos (VRF) de um processo de tratamento é definido como a razão entre o volume inicial do volume tratado $V_{0}$ e o volume final, após o tratamento $\mathrm{V}_{\mathrm{f}}(E Q .1)$ (OJOVAN e LEE, 2014):

$$
\mathrm{VRF}=\frac{V_{0}}{V_{\mathrm{f}}}
$$

Quanto maior o VRF, mais eficiente é o processo de tratamento. No entanto, a redução do volume conduz inevitavelmente à concentração de radionuclídeos, o que pode ter impacto sobre a segurança e a economia do processo. 
O tratamento também pode levar a vários tipos de rejeitos radioativos secundários, tais como filtros, resinas de troca iônica e lamas contaminadas ou qualquer outro tipo de material usado como sorvente. Após o tratamento, dependendo do teor de radionuclídeos nos rejeitos, estes podem ou não necessitar de imobilização.

$\mathrm{Na}$ maioria dos casos, o tratamento de rejeitos líquidos visa dividi-los em duas frações: a primeira é uma pequena quantidade de concentrado que contém a maior parte dos radionuclídeos e a segunda é um grande volume, cujo nível de contaminação é suficientemente baixo para permitir a sua descarga para o meio ambiente, como ilustrado no esquema da FIG.3.

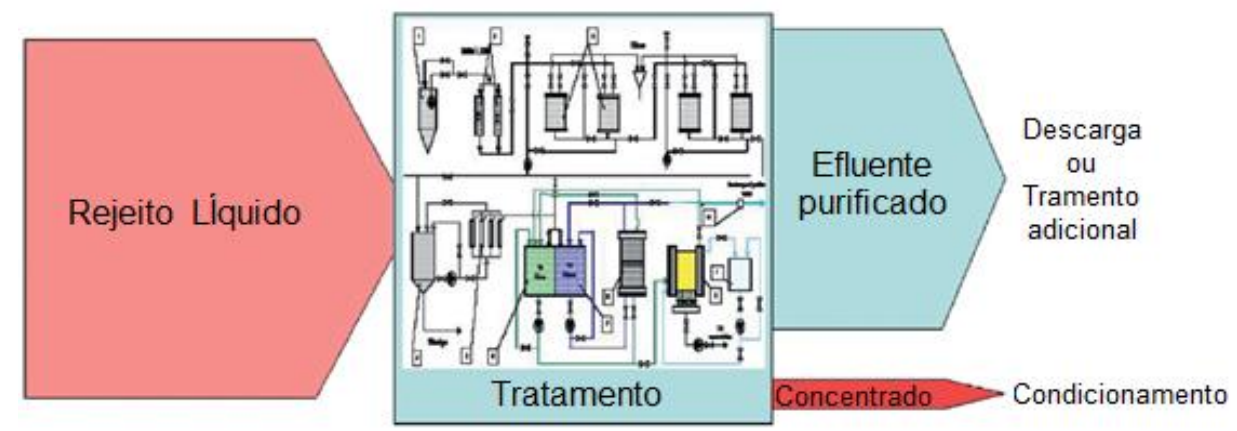

FIGURA 3 - Esquema do tratamento do Rejeito Radioativo. Fonte: (OJOVAN e LEE, 2014).

O fator de descontaminação (DF) obtido através do processo de tratamento líquido é definido como a razão entre a concentração inicial de radionuclídeos no rejeito $A_{0}$ e a concentração final (por exemplo, água purificada) após o tratamento $A_{f}$ apresentando na (EQ.2):

$$
\mathrm{DF}=\frac{A_{0}}{A_{\mathrm{f}}}
$$

\subsubsection{Técnicas de tratamento}

$\mathrm{Na} T A B .3$ ilustra-se as aplicações, as características e as limitações das principais técnicas comuns de tratamento do rejeito liquido (RAHMAN, IBRAHIUM e HUNG, 2011). 
TABELA 3 - Aplicações, características e limitações mais significativas das principais técnicas empregadas no tratamento de Rejeitos Radioativos Líquidos.

Fonte: (RAHMAN, IBRAHIUM e HUNG, 2011).

\begin{tabular}{|c|c|c|}
\hline Técnica & Aplicação e caraterísticas & Limitações \\
\hline - Precipitação & $\begin{array}{l}\text { - Adequada para rejeitos de grandes } \\
\text { volumes e de alto conteúdo em sais } \\
>1 \mathrm{~g} / \mathrm{L} \\
\text { - Operações de baixo custo fáceis }\end{array}$ & $\begin{array}{l}\text { - Baixo DF } \sim 10-10^{2} \text { para } \beta \text { e } \\
\left.\gamma, \sim 10-10^{3} \text { para } \alpha\right) \\
\text { - A eficiência depende do } \\
\text { passo da separação sól-líq. }\end{array}$ \\
\hline $\begin{array}{l}\text { - Sorção/ } \\
\text { Troca-iônica }\end{array}$ & $\begin{array}{l}\text { - Boa estabilidade química, térmica e } \\
\text { frente a radiação. } \\
\text { - Grande escolha de produtos que } \\
\text { garantem alta seletividade. } \\
\text { - Trocadores orgânicos (DF } \sim 10-10^{3} \text { ) } \\
\text { quando a solução apresenta baixo } \\
\text { conteúdo em sais < } 1 \mathrm{~g} / \mathrm{L} \text { ou } \\
\text { trocadores inorgânicos (DF } 10-10^{4} \text { ) } \\
\text { quando a sorção é seletiva }\end{array}$ & $\begin{array}{l}\text { - Afetado por alto conteúdo } \\
\text { em sais. } \\
\text { - Problemas de bloqueio ou } \\
\text { obstrução. } \\
\text { - Difícil uso como materiais } \\
\text { de regeneração, assim } \\
\text { como a sua reciclagem }\end{array}$ \\
\hline - Evaporação & $\begin{array}{l}\text { - Grandes volumes } \\
\text { - Técnica bem estabelecida. } \\
\text { - Adequada para vários } \\
\text { radionuclídeos. } \\
\text { - DF }>10^{4}-10^{6}\end{array}$ & $\begin{array}{l}\text { - Limitações de processo } \\
\text { (formação de espuma, } \\
\text { corrosão e a volatilidade de } \\
\text { certos radionuclídeos) } \\
\text { - Dificuldade de operação e } \\
\text { elevado custo. }\end{array}$ \\
\hline - Ultrafiltrarão & $\begin{array}{l}\text { - Técnica de pre-tratamento } \\
\text { posteriormente combinada com } \\
\text { outras técnicas. } \\
\text { - DF }>\sim 10^{2} \text { (remove partículas e } \\
\text { coloides) } \\
\text { - Separação de sais dissolvidas de } \\
\text { matérias particulados e coloidais. } \\
\text { - Boa estabilidade química e } \\
\text { radioativa para membranas } \\
\text { inorgânicas. }\end{array}$ & $\begin{array}{l}\text { - Entupimento } \\
\text { - Membranas orgânicas } \\
\text { sujeitas à dose de radiação. }\end{array}$ \\
\hline - Microfiltração & $\begin{array}{l}\text { - Técnica de pre-tratamento } \\
\text { posteriormente combinada com } \\
\text { outras técnicas } \\
\text { - Alta recuperação (99\%) } \\
\text { - Remove particulados. } \\
\text { - Baixo entupimento quando lavado } \\
\text { com ar na limpeza. }\end{array}$ & $\begin{array}{l}\text { - Sensível às impurezas } \\
\text { presentes nos rejeitos }\end{array}$ \\
\hline $\begin{array}{l}\text { - Osmose } \\
\text { inversa }\end{array}$ & $\begin{array}{l}\text { - Grandes volumes com baixo custo } \\
\text { - Remove os sais dissolvidos. } \\
\text { - DF }>10^{2}-10^{3} \\
\text { - Estabelecido para várias operações } \\
\text { em escala }\end{array}$ & $\begin{array}{l}\text { - Sistema de altas pressões, } \\
\text { limitado pela pressão } \\
\text { osmótica. } \\
\text { - No lavado está sujeito a } \\
\text { entupimento }\end{array}$ \\
\hline
\end{tabular}

DF=Fator de descontaminação

Devido a existência de uma grande variedade de composições químicas e radioquímicas de rejeitos líquidos, um número considerável de técnicas de 
tratamento tem sido desenvolvidas para purificar efluentes líquidos radioativos. As técnicas de tratamento de rejeitos líquidos mais desenvolvidas são: evaporação, precipitação química, sorção/troca iônica, microfiltração, osmose inversa e ultrafiltração. Na prática, vários métodos são usados geralmente em combinação, como por exemplo, evaporação seguida por sorção/troca iônica (RAHMAN, IBRAHIUM e HUNG, 2011). Apesar disso, na atualidade, ainda não foi estabelecida uma tecnologia confiável e padronizada ou uma combinação entre várias técnicas, que possa ser considerada como uma referência para o tratamento dos rejeitos radioativos líquidos, principalmente quando estes apresentam radioisótopos em baixas concentrações (EROGLU, YAPICI, et al., 2009).

Pesquisas em vários países têm buscado soluções que visam o emprego de materiais de baixo custo e uso sustentável, assim como o melhor desenvolvimento das técnicas, na área de tratamento de rejeitos radioativos líquidos (RLL) (FIG.4):

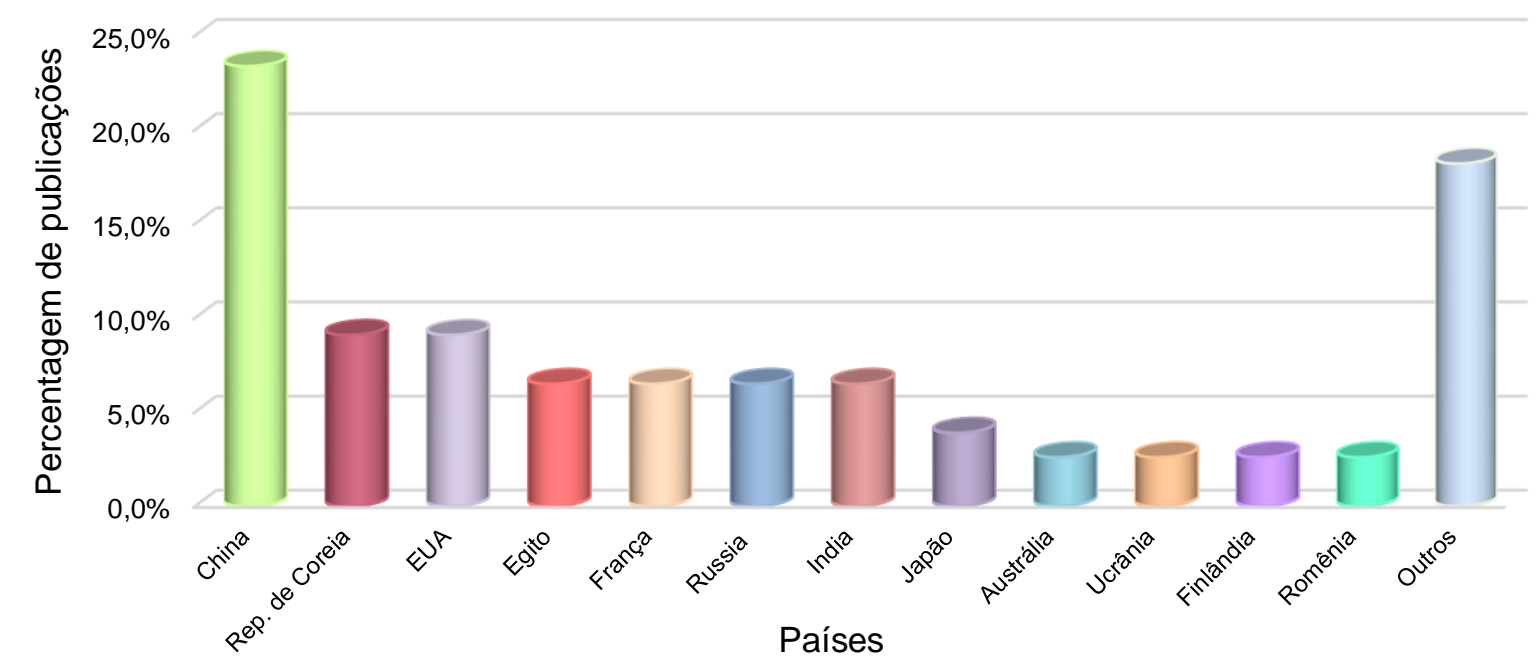

Fonte: www.sciencedirect.com (procura por "materials" e "tecnhique treament waste liquid radioactive") Com base nas 100 publicaçỏes mais relevantes (14/03/2016)

FIGURA 4 - Publicações relevantes por país nas áreas de materiais e técnicas de tratamento de rejeito radioativo liquido (RRL) desde 2014 - Presente. (Autor)

\subsubsection{Técnica de sorção /troca iônica}

A sorção define-se como transferência de uma substância de uma fase líquida para uma fase sólida - enquanto que o inverso chama-se dessorção. Esta retenção se dá por diversos mecanismos, cujas contribuições individuais podem ser difíceis de isolar (ALLEONI, CAMARGO, et al., 2009). Por este motivo, quando 
não se conhecem os mecanismos envolvidos é comum referir-se genericamente a esta retenção pelo termo sorção (THOMPSON e GOYNE, 2012; SPOSITO, 1989).

Os principais mecanismos de sorção conhecidos podem ser classificados de acordo com o tipo de ligação envolvida (IAEA, 2002):

- Adsorção física. Não há troca de elétrons na sorção física, as atrações intermoleculares são independentes das propriedades eletrônicas das moléculas envolvidas. A espécie adsorvida conserva a sua natureza química. O calor de adsorção (Forças de Van der Waals), é baixo e, por conseguinte, este tipo de sorção é estável apenas a temperaturas abaixo de cerca de $150^{\circ} \mathrm{C}$.

- Adsorção química. A sorção química, ou quimissorção, envolve uma troca de elétrons entre sítios ativos superficiais específicos de soluto (material sorvente) e os íons presentes na solução, o que resulta na formação de uma ligação química. A espécie adsorvida sofre uma transformação, mais ou menos intensa, dando lugar a uma nova espécie. A quimissorção é caracterizada por uma energia de sorção mais elevada do que a sorção física e, portanto, mais estável em altas temperaturas.

- Sorção eletrostática (troca iônica). Este é um termo reservado para as forças de atração de Coulomb entre íons e grupos funcionais carregados e é mais comumente classificada como troca iónica. A troca iônica consiste na simultaneidade estequiométrica e instantânea dos fenômenos de sorção e dessorção de íons. A sorção de metais pesados nos argilominerais é uma troca catiônica particular (BERGAYA, LAGALY e VAYER, 2013). Além disso, os íons de metais pesados podem precipitar na superfície sorvente sob a forma de hidróxidos, hidroxi carbonatos, ou outros sais básicos.

Neste trabalho, o processo será denomidado de sorção devido a dificultade de isolar as contribuições individuais dos possíveis mecanismos envolvidos.

Para remover cátions presentes na solução, frequentemente são utilizadas resinas catiônicas. Por exemplo, um trocador catiônico pode liberar seu íon hidrogênio em solução e adsorver um cátion metálico, $\mathrm{Me}^{+}$existente na solução (EQ.3)

$$
\mathrm{R}-\mathrm{H}+\mathrm{Me}^{+} \leftrightarrow \mathrm{R}-\mathrm{Me}+\mathrm{H}^{+}
$$

Onde, $\mathrm{R}$ é a parte insolúvel do trocador catiônico, $\mathrm{H}$ é o cátion hidrogênio pressente no trocador catiônico e $\mathrm{Me}^{+}$é o cátion metálico presente na solução. 
A eficiência de purificação depende de parâmetros importantes como são a capacidade de sorção, a durabilidade química e a resistência mecânica da matriz (OJOVAN e LEE, 2014).

As isotermas de sorção aportam informação sobre a concentração de uma espécie sorvida no trocador iônico, expressada como função da sua concentração na solução, em condições específicas de volume, massa e pH, a temperatura constante (OJOVAN e LEE, 2014).

A concentração dos radionuclídeos nos materiais com propriedades de sorção ou de troca catiônica é expressada em termos de capacidade de sorção (K) (EQ.4). K é o número de miliequivalentes molares ( $\mathrm{mEq}$ ), moles (mol) ou miligramas (mg) do radionuclídeo retido por unidade de massa $(\mathrm{g})$ do material sorvente (seco). Estes valores são constantes e característicos para um dado material e dependem das condições de tratamento (OJOVAN e LEE, 2014). O parâmetro de máxima capacidade de sorção $(K)$, representado na $E Q$. 4 é o mais utilizado para caracterizar os materiais usados como sorventes ou trocadores iônicos

$$
K=\left(C_{0}-C_{\mathrm{e}}\right) \frac{V}{M}
$$

Onde: $\quad C_{0}$ é o a concentração inicial $\left(\mathrm{mg} \cdot \mathrm{mL}^{-1}\right)$, Ce é a concentração de equilíbrio dos íons na solução $\left(\mathrm{mg} \cdot \mathrm{mL}^{-1}\right)$, V é o volume de solução $(\mathrm{mL})$ e $\mathrm{M}$ é a massa do sorvente seco $(\mathrm{g})$.

\subsubsection{Passado, presente e futuro dos materiais usados no tratamento por sorção/ troca iônica}

Em geral, os trocadores iônicos orgânicos são os mais utilizados para a remoção e concentração de radionuclídeos. No entanto, recentemente houve um enorme interesse na utilização de materiais inorgânicos com propriedades de sorção/ troca iônica para a remoção de íons metálicos e radionuclídeos na área ambiental, nuclear e radioanalítica química (BANERJEE, DUDWADKAR, et al., 2014).

As principais características que justificam o crescimento de uso dos trocadores iônicos ou sorventes inorgânicos ao invés dos orgânicos sintéticos, residem na sua alta estabilidade térmica e à radiação, assim como na 
compatibilidade com matrizes utilizadas para a imobilização de radionuclídeos conjuntamente com uma alta capacidade e seletividade na remoção de determinados radionuclídeos. Além de possuírem elevada estabilidade química e razoável funcionamento em um intervalo de $\mathrm{pH}$ mais amplo (BANERJEE, DUDWADKAR, et al., 2014).

Existe uma extensa variedade de materiais inorgânicos com propriedades de sorção/ troca iônica citadas na literatura. As zeólitas naturais foram os primeiros trocadores iônicos usados na purificação de efluentes na escala comercial (CLIFFORD, 1999). Na última década, em relação à remoção específica de alguns radionuclídeos, os materiais propostos foram: zeólitas (DELKASH, BAKHSHAYESH e KAZEMIAN, 2015), zeólitas sintéticas (DELKASH, BAKHSHAYESH e KAZEMIAN, 2015), carvão ativado (PYRZYNSKA e BYSTRZEJEWSKI, 2010), titânio-silicatos (PAVEL e POPA, 2014) fosfatos de zircônio (MOLLER, BESTAOUI, et al., 2011), argilominerais (GASKOVA e BUKATY, 2008; GALUNIN, ALBA, et al., 2011; QIU, YU, et al., 2013) e argilominerais pilarizados (SYLVESTER, CLEARFIELD e DIAZ, 1999).

$\mathrm{Na}$ atualidade, tem se destacado considerável atenção na síntese de materiais nanocristalinos aumentando as suas aplicações industriais (BANERJEE, DUDWADKAR, et al., 2014). O potencial dos nanomateriais inorgânicos, visando a remoção de íons tóxicos ou radionuclídeos, não tem sido suficientemente explorado e na atualidade é escassamente relatado.

Os nanomateriais possuem uma área superficial específica extremadamente alta, reatividade e um grande número de sítios ativos para a sorção, considerando que os seus análogos micrométricos possuem limitações químicas e físicas, em termos de área superficial específica, sítios ativos e cinéticas de reações de sorção (LEE, KIM, et al., 2016).

Dentre os nanomateriais sintéticos estudados na literatura podem-se destacar: nanotubos de carbono (STAFIEJ e PYRZYNSKA, 2007; PYRZYNSKA e BYSTRZEJEWSKI, 2010), grafeno (ZHAO, LI, et al., 2011), nanocompósitos de silicato em camadas de polímero (PAVLIDOU e PAPASPYRIDES, 2008) e nanopartículas formadas por metais ou óxidos metálicos como o nano-cério vanádio (BANERJEE, DUDWADKAR, et al., 2014). O número de estudos observados sobre nano-adsorventes fundamentados em nanomateriais naturais é 
muito mais reduzido que dos nanomateriais sintéticos. Um dos nanomateriais naturais pesquisados na literatura são as nano-zeólitas (LEE, KIM, et al., 2016).

$\mathrm{Na}$ evolução das pesquisas na gestão de rejeitos, um fenômeno que focou e vem recebendo considerável atenção é a imobilização dos radionuclídeos nos próprios materiais usados como sorventes ou trocadores iônicos, visando a imobilização das espécies após o tratamento de redução de volume do rejeito (ROBINSON, 1962; KOMARNENI e ROY, 1978).

No caso dos argilominerais, também existem estudos visando o uso como "barreiras de confinamento", necessárias para evitar a migração de radionuclídeos para fora dos repositórios finais (VILLA-ALFAGEME, HURTADO, et al., 2015).

A imobilização dos radionuclídeos nos argilominerais após o tratamento de redução de volume de rejeito radioativo, é acompanhada por processos térmicos (AMPHLETT e WARREN, 1956; SINHA e KRISHNASAMY, 1996, RASHID e GHAFFAR, 2010). Se a matriz usada para a retenção de íons radioativos for inerte à radiação e atender os critérios específicos da cada país, como resistência mecânica, estabilidade térmica, compatibilidade química, carregamento de rejeito, resistência à biodegradação, lixiviação e radiação (IAEA, 2002), podem ser armazenados até o decaimento final na mesma matriz ou compatibilizados com uma matriz sólida inerte (cimento, vidro, plástico) para a sua disposição final (SINHA e KRISHNASAMY, 1996; LIMA, BOSH e BULBULIAN, 2007; RASHID e GHAFFAR, 2010; WANG e WAN, 2015)

\subsubsection{Proposta e motivação do uso de nanotubos naturais ativados para incorporar radionuclídeos}

Dentre os filosilicatos usados como nanotubos naturais na engenharia de materiais (PASBAKHSH e CHURCHMAN, 2015), encontram-se dois argilominerais como possíveis candidatos a remoção de radionuclídeos: a paligorsquita e a sepiolita.

Na FIG.5 ilustra-se a representação esquemática dos nanotubos naturais, a célula unitária e a formula teórica da paligorsquita. 


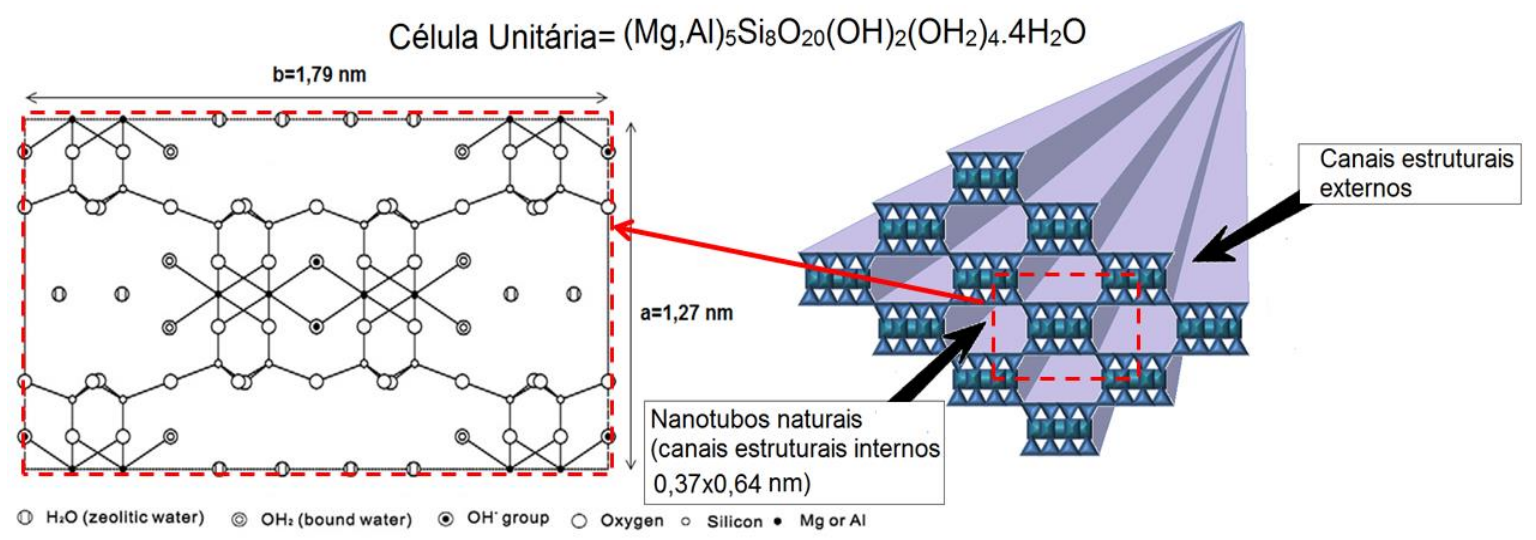

FIGURA 5 - Representação esquemática dos nanotubos naturais, dos canais externos da estrutura e da célula unitária da paligorsquita. (Autor)

A paligorsquita e a sepiolita, pertencem ao mesmo grupo argilomineral e possuem propriedades físico e químicas similares (GALAN e SINGER, 2011), ambos têm sido estudados na literatura para a remoção de metais radioativos, pesados ou tóxicos $\left(\mathrm{Ni}^{2+}, \mathrm{Co}^{2+}, \mathrm{Cu}^{2+}, \mathrm{Cd}^{2+}, \mathrm{Zn}^{2+}\right.$, etc.), apresentando consideráveis capacidades de sorção (CHEN, ZHAO e WANG, 2007; FAN, SHAO, et al., 2009; HE, ZHU, et al., 2011; QIU, YU, et al., 2013).

Além disso, para estes argilominerais foram relatados mecanismos de ativação superficial que tem por objetivo aumentar a área superficial específica e o número de sítios ativos, sendo estas as duas principais características que requerem os materiais usados nos processos de sorção/troca iônica (CHEN, ZHAO e WANG, 2007; ESTEBAN-CUBILLO, PINA-ZAPARDIEL, et al., 2008; HUO e YANG, 2012).

A motivação principal para realizar este estudo de incorporação de radionucídeos foi a possibilidade desenvolver um processo de ativação superficial para incorporar radionuclídeos de forma eficaz em nanotubos naturais ativados da paligorsquita, estudando o papel da lixiviação dos cátions de magnésio na estabilidade estrutural e na incorporação dos radionuclideos presentes nos efluentes nucleares. Tendo por base os estudos apresentados por ESTEBANCUBILLO, PINA-ZAPARDIEL, et al. (2008), para a sepeolita. Aumentando portanto a capacidade de sorção deste argilomineral.

Adicionalmente, para estes argilominerais fibrilares foi observada na literatura a possibilidade do colapso estrutural irreversível dos nanotubos por tratamento térmico (GONZÁLEZ, PESQUERA e BENITO, 1993; ESTEBAN- 
CUBILLO, PINA-ZAPARDIEL, et al., 2008), o que possivelmente podera contribuir para a imobilização de radionuclideos anteriormente incorporados na matriz.

O número de publicações utilizando a paligorsquita vem aumentando na última década, destacando-o como um argilomineral de interesse (FIG.6).

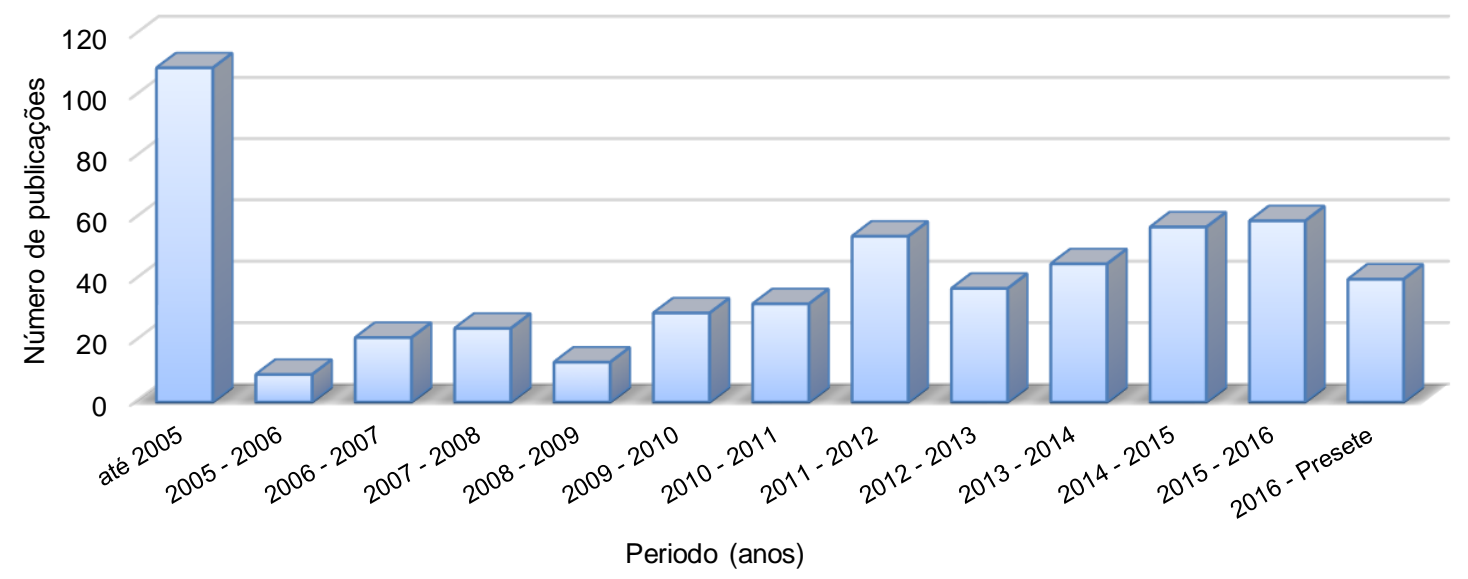

Fonte: www.sciencedirect.com (procura por "palygorskite" e "attapulgite")(14/03/2016)

FIGURA 6 - Número de publicações científicas realizadas utilizando paligorsquita.

(Autor)

O estudo desta classe de materiais naturalmente nanoestruturados para aplicações como nanosorventes de radionuclídeos vem de encontro à solução de um problema crescente que é a geração de efluentes radioativos decorrentes de atividades nucleares nos mais diversos setores de aplicação desta tecnologia. Neste sentido, a contribuição na redução de volume de rejeitos por adensamento para a disposição final, inertização e imobilização por processos de aprisionamento em nanotubos da paligorsquita, constitui uma interessante contribuição ambiental.

A existência de grandes depósitos de paligorsquita em território nacional, concretamente no estado do Piauí (Brasil), viabiliza este estudo e justifica o grande interesse no desenvolvimento tecnológico de produtos com alto valor agregado a partir deste insumo argilomineral.

\subsection{Seleção dos cátions procedentes do rejeito radioativo}

No rejeito radioativo líquido podem-se encontrar cátions radioativos procedentes de produtos das reações de fissão no combustível nuclear $\left({ }^{90} \mathrm{Sr},{ }^{99} \mathrm{Tc}\right.$, 
${ }^{137} \mathrm{Cs},{ }^{129},,{ }^{134} \mathrm{Cs}$, etc.), de produtos de ativação $\left({ }^{94} \mathrm{Nb},{ }^{60} \mathrm{Co},{ }^{63} \mathrm{Ni},{ }^{54} \mathrm{Mn},{ }^{59} \mathrm{Ni}\right.$, etc.) e de produtos da transmutação de radionuclídeos ou transurâncios $\left({ }^{235} \mathrm{U},{ }^{238} \mathrm{U},{ }^{239} \mathrm{Pu}\right.$, ${ }^{240} \mathrm{Pu},{ }^{241} \mathrm{Pu}$ e ${ }^{242} \mathrm{Pu}$, etc.), como se ilustrou na TAB.2.

Os íons seleccionados neste trabalho para simular os efluentes radioativos foram o níquel $\left(\mathrm{Ni}^{2+}\right)$, o e o estrôncio $\left(\mathrm{Sr}^{2+}\right)$. Estes elementos foram adicionados a partir de íons inativos, provenientes dos sais de $\mathrm{NiCl}$ e $\mathrm{Sr}\left(\mathrm{NO}_{3}\right)_{2}$. Optou-se por trabalhar com os solutos inativos pois, além de não apresentarem risco, segue-se um dos princípios gerais da Gestão de Rejeitos Radioativos que é não-geração de rejeitos desnecessários. Estes íons foram selecionados, porque seus radioisótopos, o ${ }^{63} \mathrm{Ni}$ e $0{ }^{90} \mathrm{Sr}$, são considerados potencialmente críticos.

\subsubsection{Niquel-63}

Dos seis principais isótopos radioativos do níquel, apenas dois - o níquel-59 e o níquel-63 - têm meias vidas suficientemente longas como para justificar preocupação. As meias-vidas de todos os outros isótopos de níquel são inferiores a seis dias. O Ni-59 decai com uma meia-vida de 75.000 anos por captura de elétrons, e o Ni-63 decai com uma meia-vida de 96 anos, emitindo uma partícula beta (PETERSON, MACDONELL, et al., 2007).

As propriedades radioativas dos principais isótopos radioativos do níquel estão representadas na TAB.4.

TABELA 4 - Propriedades radioativas dos principais isótopos radioativos do Níquel. Fonte: (PETERSON, MACDONELL, et al., 2007).

\begin{tabular}{ccccccc}
\hline Isótopo & Meia- & Atividade & Modo de & \multicolumn{3}{c}{ Energia de radiação (MeV) } \\
\cline { 6 - 8 } & vida & especifica & decaimento & Alpha & Beta & Gamma \\
& (anos) & $(\mathrm{Bq} / \mathrm{g})$ & & $(\alpha)$ & $(\beta)$ & $(\gamma)$ \\
\hline Ni-59 & 75000 & $3,03 \cdot 10^{9}$ & EC & - & 0,0046 & 0,0024 \\
Ni-63 & 96 & $2,22 \cdot 10^{12}$ & $\beta$ & - & 0,017 & - \\
\hline
\end{tabular}

Ambos os radionuclídeos estão presentes em rejeitos procedentes de efluentes nucleares líquidos e são produzidos por ativação de nêutrons. Estes são gerados por ativação neutrônica no processo de fissão, no qual um átomo de 
urânio-235, geralmente, se divide de forma assimétrica em dois grandes fragmentos denominados produtos de fissão com números de massa em torno de 90 e 140, mais dois ou três nêutrons. Estes nêutrons podem causar fissões adicionais (produzindo uma reação em cadeia), escapar do reator ou irradiar materiais nas proximidades (PETERSON, MACDONELL, et al., 2007).

Um número importante de componentes do reator é feito de várias ligas de aços que contêm cromo, manganês, níquel, ferro, cobalto e, podem absorver nêutrons e transformam-se em radionuclídeos radioativos, como o $\mathrm{Ni}-63$ e Ni-59 (PETERSON, MACDONELL, et al., 2007).

Nos seres vivos, o níquel radioativo apresenta um perigo para a saúde devido à radiação beta e gama. Para o corpo humano, a principal preocupação está associada com o aumento da probabilidade de indução de câncer (PETERSON, MACDONELL, et al., 2007)

\subsubsection{Estrôncio-90}

O estrôncio-90 (Sr-90) tem uma meia vida suficientemente longa (29 anos) para justificar preocupação dos organismos que regulam a segurança das instalações nucleares. As meias vidas de todos os outros radionuclídeos de estrôncio são menores do que 65 dias. O estrôncio-90 decai para ítrio-90, emitindo uma partícula beta, e o ítrio-90 decai por emissão de uma partícula beta mais energética com uma meia vida de 64 horas decaindo para o zircónio-90.

As propriedades radioativas do estrôncio e do radionuclídeo associado no decaimento estão representadas na TAB.5.

TABELA 5 - Propriedades radioativas do estrôncio e do radionuclídeo associado no decaimento. Fonte: (PETERSON, MACDONELL, et al., 2007).

\begin{tabular}{|c|c|c|c|c|c|c|}
\hline \multirow[t]{2}{*}{ Isótopo } & \multirow{2}{*}{$\begin{array}{l}\text { Meia- } \\
\text { vida }\end{array}$} & \multirow{2}{*}{$\begin{array}{c}\text { Atividade } \\
\text { especifica } \\
\qquad(B q / g)\end{array}$} & \multirow{2}{*}{$\begin{array}{c}\text { Modo de } \\
\text { decaimento }\end{array}$} & \multicolumn{3}{|c|}{ Energia de radiação (MeV) } \\
\hline & & & & $\begin{array}{c}\text { Alpha } \\
(\alpha)\end{array}$ & $\begin{array}{c}\text { Beta } \\
(\beta)\end{array}$ & $\begin{array}{c}\text { Gamma } \\
(\gamma)\end{array}$ \\
\hline Sr-90 & 29 anos & $5,18 \cdot 10^{12}$ & $\beta$ & - & 0,20 & - \\
\hline$Y-90$ & $64 \mathrm{~h}$ & $2,032 \cdot 10^{16}$ & $\beta$ & - & 0,94 & $<$ \\
\hline
\end{tabular}


O Sr-90 também é produzido durante as reações de fissão nuclear a partir do U-235, possuindo um rendimento durante o processo de cerca de $6 \%$ atómico. O estrôncio-90 encontra-se na composição dos rejeitos radioativos resultantes do processamento do combustível nuclear irradiado e nos efluentes associados ao funcionamento dos reatores e instalações nucleares (PETERSON, MACDONELL, et al., 2007).

O Sr-90 é perigoso para a saúde, se ingerido. Devido à similaridade química com o cálcio $\left(\mathrm{Ca}^{2+}\right)$, o Sr-90 tende a acompanhá-lo, sendo assimilado pelos seres vivos, concentrando-se em superfícies ósseas e medula óssea, e como sua meiavida radioativa é relativamente longa (29 anos) torna o um dos produtos mais perigosos de contaminação radioativa. Tumores ósseos e nas células sanguíneas da medula óssea são a principal preocupação para a saúde (PETERSON, MACDONELL, et al., 2007).

\subsection{Argilominerais}

As argilas e os argilominerais, modificados ou não, serão reconhecidos como os materiais do século XXI, devido à sua abundância, baixo custo, aplicabilidade e por serem ambientalmente amigáveis (BERGAYA, THENG e LAGALY, 2006).

SOUZA-SANTOS, 1989, define argila como um material natural, terroso, de granulação fina $(<2 \mu \mathrm{m})$ que quando umedecido com água apresenta plasticidade, e é constituída essencialmente por um grupo restrito de minerais que recebem o nome de argilominerais.

Devido à sua origem, as argilas contêm em geral matéria orgânica, sais solúveis, areia (quartzo), feldspato, mica, pirita, calcita, clorita, sulfatos, sulfetos, carbonatos e outros minerais residuais, além dos próprios argilominerais.

Os argilominerais são silicatos hidratados de alumínio ou magnésio, que pertencem à família dos filossilicatos (do grego phyllos: folhas), de estrutura cristalina na forma de lamelas ou fibras (SOUZA-SANTOS, 1989).

Os argilominerais são constituídos por folhas, planos ou camadas de tetraedros de silício e oxigênio, e por folhas, planos ou camadas de octaedros de alumínio ou magnésio, oxigênio e hidroxilas como apresentado na FIG.7. Cada unidade das folhas constituídas por tetraedros de silício e oxigênio ( $\left.\mathrm{SiO}_{4}\right)$ FIG.7.a, compartilha, nas duas dimensões, três dos quatro átomos de oxigênio com os 
tetraedros vizinhos, formando anéis de seis tetraedros (anéis hexagonais), FIG.7.b; essa camada é denominada de "folha siloxano" ou simplesmente de "folha tetraédrica (T)" (MOTT, 1988). Essas folhas podem unir-se a outras folhas, formadas por octaedros de magnésio ou alumínio e oxigênio $\left(\mathrm{MgO}_{6}\right.$ ou $\left.\mathrm{AlO}_{6}\right)$ FIG.7.c, e que passam a ser denominadas de "folha octaédrica (O)", através do compartilhamento dos átomos de oxigênio, FIG.7.d.

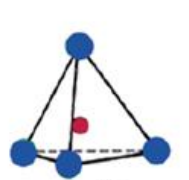

(a)

O

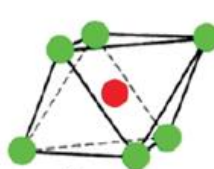

(c)

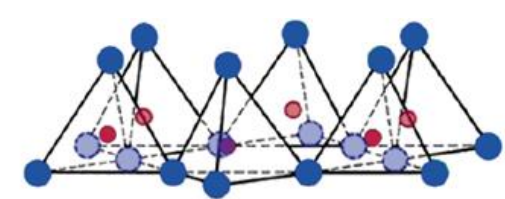

(b)

- $\mathrm{Si}$

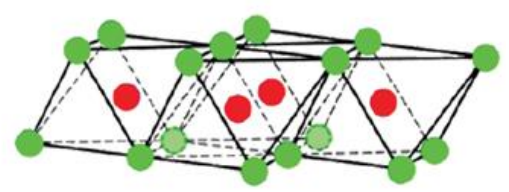

(d)

- $\mathrm{OH}$ Al, Mg

FIGURA 7 - Representação de: (a) tetraedro de silício, (b) folha tetraédrica, (c) octaedro de magnésio ou alumínio e (d) folha octaédrica. (MANGONI, 2014).

Vários tipos de argilominerais apresentam um excesso de carga negativa devido às substituições por íons de menor valência, como por exemplo, íons $\mathrm{Al}^{3+}$ substituindo os íons $\mathrm{Si}^{4+}$ das folhas tetraédricas, ou ainda substituição de $\mathrm{Al}^{3+}$ por $\mathrm{Mg}^{2+}$ nas folhas octaédricas. Tais substituições, entretanto, são consideradas isomórficas por não causarem distorção na estrutura cristalina, uma vez que estes íons possuírem tamanhos similares. Estes filossicatos são classificados de acordo com o tipo de cátion presente na folha octaédrica. Se o cátion presente for bivalente, como o $\mathrm{Mg}^{2+}$, todos os sítios octaédricos estarão ocupados, e é classificado como do tipo trioctaédrico. Se o cátion for trivalente como $\mathrm{Al}^{3+}$ ou $\mathrm{Fe}^{3+}$, somente $2 / 3$ dos sítios estarão ocupados e, neste caso, o argilomineral é denominado dioctaédrico. Estes minerais também são classificados de acordo com o tipo de camada considerando a razão entre as folhas tetraédricas e as octaédricas em: i) camadas do tipo 1:1 quando têm uma folha tetraédrica e uma octaédrica (também conhecidas com "TO"); ii) camadas do tipo 2:1 quando apresentam duas folhas tetraédricas e 
uma octaédrica interna (também conhecidas como "TOT") (SOUZA-SANTOS, 1989).

O Comitê International pour l'Étude dês Argiles (CIPEA), recomenda a subdivisão dos argilominerais cristalinos em: a) Argilominerais lamelareis, e b) argilominerais fibrilares (SOUZA-SANTOS, 1989).

Os minerais contidos nas argilas são classificados e conhecidos por grupos, por exemplo, com base nas semelhanças em composição química e/ou na estrutura cristalina, e são geralmente derivados de um mineral de origem. Uma classificação dos argilominerais pode ser realizada segundo o tipo de reticulado cristalino (lamelar ou fibroso), segundo a disposição estrutural (1:1 ou 1:2) e segundo o grupo, o subgrupo e a espécie, como apresentando na TAB.6 (SOUZA-SANTOS, 1989).

TABELA 6 - Classificação dos argilominerais.

\begin{tabular}{|c|c|c|c|c|}
\hline Classe Geral & Família & Grupo & Camada octaédrica & Argilominieral \\
\hline \multirow{12}{*}{$\begin{array}{c}\text { Estrutura } \\
\text { lamelar }\end{array}$} & \multirow{2}{*}{$1: 1$} & Caulinita & Dioctaédrica & $\begin{array}{c}\text { Nacrita, Caulinita, } \\
\text { Haloisita }\end{array}$ \\
\hline & & Serpentina & Trioctaédrica & $\begin{array}{l}\text { Antigorita, Crisolita, } \\
\text { Amesita, Cronstedita }\end{array}$ \\
\hline & \multirow{10}{*}{$2: 1$} & Esmectita & Dioctaédrica & $\begin{array}{c}\text { Beidelita, Nontronita, } \\
\text { montmorillonita }\end{array}$ \\
\hline & & & Trioctaédrica & Saponita, Hectorita \\
\hline & & Vermiculita & Dioctaédrica & Vermiculita \\
\hline & & \multirow{3}{*}{ Mica } & Trioctaédrica & Vermiculita \\
\hline & & & Dioctaédrica & $\begin{array}{l}\text { Muscovita-Illita, } \\
\text { Flogopita }\end{array}$ \\
\hline & & & Trioctaédrica & $\begin{array}{l}\text { Biotita-Lediquita, } \\
\text { Lepidolita }\end{array}$ \\
\hline & & \multirow{2}{*}{$\begin{array}{l}\text { Talco- } \\
\text { pirofilita }\end{array}$} & Dioctaédrica & Pirofilita \\
\hline & & & Trioctaédrica & Talco \\
\hline & & \multirow{2}{*}{ Clorita } & Dioctaédrica & Dombassita \\
\hline & & & Trioctaédrica & $\begin{array}{l}\text { Clinocloro, } \\
\text { Chamosita }\end{array}$ \\
\hline \multirow{2}{*}{$\begin{array}{l}\text { Estrutura } \\
\text { fibrilar }\end{array}$} & \multirow{2}{*}{$2: 1$} & Paligorsquita & Di/Trioctaédrica & Paligorsquita \\
\hline & & Sepiolita & Trioctaédrica & Sepiolita \\
\hline
\end{tabular}


Os argilominerais em geral encontram-se em forma de placas lamelares ou fibras e apresentam pelo menos uma das suas dimensões em escala nanométrica, resultando como consequência em grandes áreas superficiais quimicamente ativas, i.e., com grande capacidade de sorção (UTRACKI, 2004).

\subsubsection{Sítios ativos nos argilominerais}

A reatividade superficial dos argilominerais pode ser descrita com base em seus sítios ativos. Os sítios ativos podem ser descritos e definidos com base na sua localização, arranjo geométrico dos átomos da superfície, composição química e acessibilidade (JONSTON, 1996).

Para se compreender as interações entre as espécies iônicas com a superfície do argilomineral, é necessário conhecer as propriedades químicas e físicas da superfície que contribuem na sua reatividade. Estas interações geralmente envolvem um ou mais dos seis sítios ativos descritos a seguir:

Segundo JONSTON (1996), os possíveis sítios ativos predominantes nos argilominerais são:

- Superfície neutra do siloxano.

- Sítios de substituição isomórfica.

- Cátions metálicos trocáveis e cátions estruturais.

- Moléculas de água ao redor do cátion trocável.

- Sítios hidrofóbicos.

- Sítios nas bordas ou arestas das lamelas com exposição dos grupos silanol e aluminol.

\subsubsection{Superfície neutra do siloxanos}

A superfície menos reativa encontrada em argilominerais é a camada formada pelos tetraedros de silício (siloxano) que é neutra em argilas que não apresentam substituições isomórficas (FIG.8). Como cada átomo de oxigênio faz ligações covalentes com dois átomos de silício, esses átomos de oxigênio da superfície externa (camada siloxano) tornam-se doadores fracos de elétrons, não sendo capazes de fazer fortes interações com, por exemplo, as moléculas de água. 
A superfície neutra comporta-se como uma base de Lewis fraca e tem característica predominantemente hidrofóbica (MANGONI, 2014)

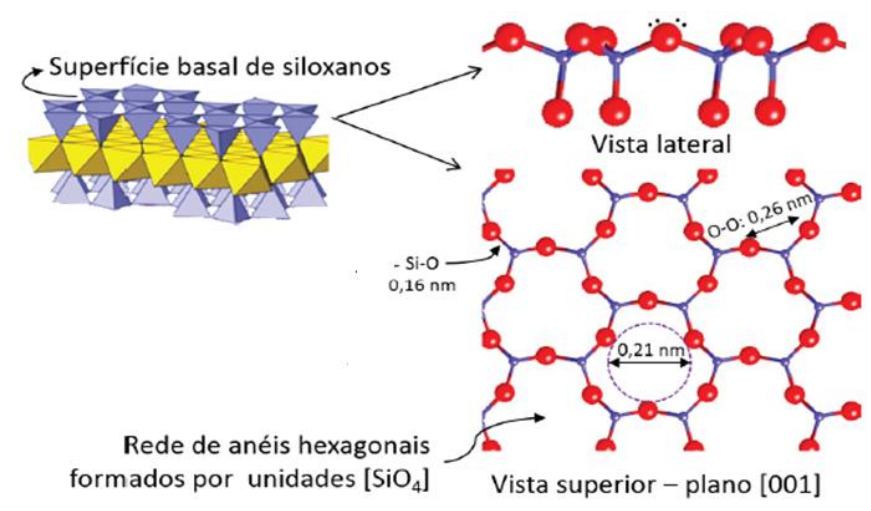

FIGURA 8 - Sítios ativos dos argilominerais 2:1: superfície dos grupos siloxanos.

Fonte: (MANGONI, 2014).

\subsubsection{Sítios de substituição isomórfica}

As substituições isomórficas conferem às argilas uma superfície basal carregada com carga negativa permanente. Em sistemas naturais essa deficiência de cargas é compensada pela presença de um cátion trocável (MANGONI, 2014).

\subsubsection{Cátions metálicos trocáveis e cátions estruturais}

Os cátions do interior dos tetraedros e octaedros também são chamados de "cátions metálicos estruturais". A natureza do cátion e o teor de água influenciam significativamente à acidez de Lewis na superfície dos argilominerais dando lugar a sítios ativos, como apresentado na FIG.9 (MANGONI, 2014)

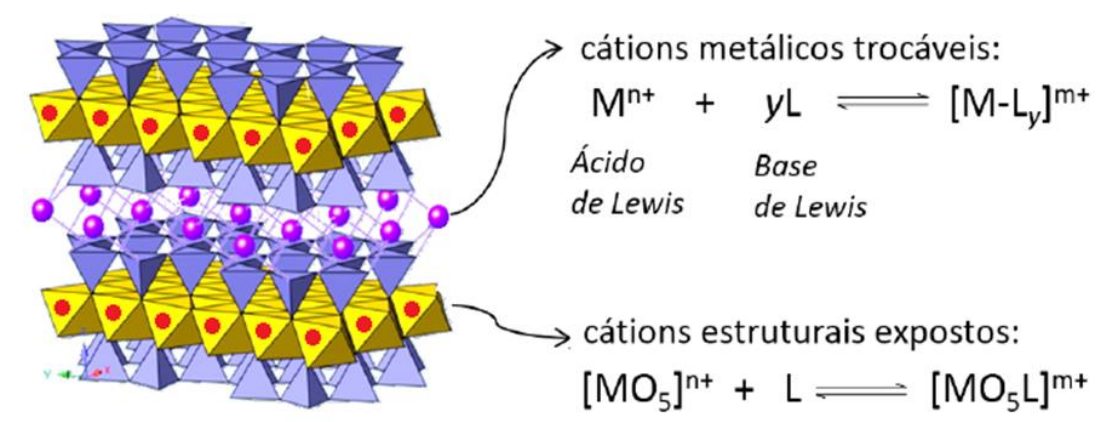

FIGURA 9 - Sítios ativos dos argilominerais: Cátions metálicos trocáveis e cátions estruturais contendo esfera de coordenação insaturada. Fonte:(MANGONI, 2014). 


\subsubsection{Moléculas de água ao redor do cátion trocável}

Há dois ambientes distintos de sorção de água nas argilas: a) moléculas de água coordenadas diretamente ao cátion metálico trocável e b) moléculas de água sorvidas nos poros intersticiais, nos espaços interlaminares entre os cátions metálicos trocáveis ou nos sítios polares na superfície externa (MANGONI, 2014).

Nesses dois ambientes essas moléculas de água são fontes de acidez de Brönsted, pois a água pode doar prótons, como é descrito na FIG.10. Essa acidez de Brönsted na superfície dos argilominerais pode ser bastante elevada e depende da natureza do cátion metálico trocável e da quantidade de água presente. Observa-se que quanto maior a razão carga / raio do íon metálico no espaço interlamelar, maior o caráter ácido de Brönsted da argila. Quanto menor o grau de hidratação do íon, maior a sua acidez (JONSTON, 1996).

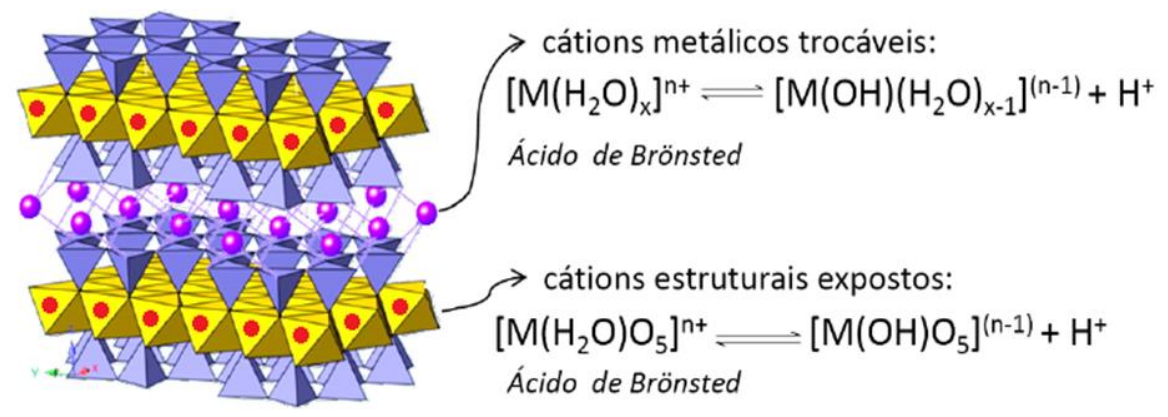

FIGURA 10 - Sítios ativos dos argilominerais: moléculas de água polarizadas ao redor de cátions trocáveis e cátions nas arestas. Fonte: (MANGONI, 2014).

\subsubsection{Sítios hidrofóbicos}

Os sítios hidrofóbicos surgem das reações das argilas com cátions orgânicos, que geram as chamadas "argilas organofílicas", tornando-as hidrofóbicas, como ilustrado na FIG.11 (MANGONI, 2014). 


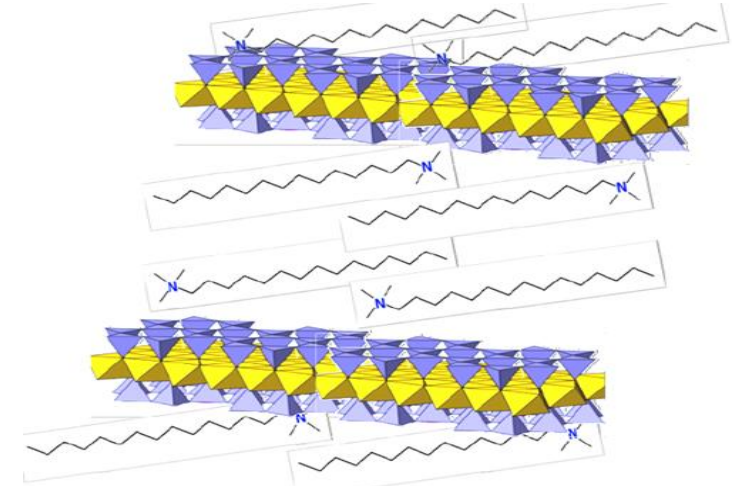

FIGURA 11 - Sítios ativos dos argilominerais: Sítios hidrofóbico. Fonte: (MANGONI, 2014).

\subsubsection{Sítios nas bordas ou arestas das lamelas com exposição dos grupos silanol e aluminol}

Os sítios ativos na forma de grupos silanol e aluminol são gerados, em geral, a partir dos grupos hidroxila localizados nas bordas rompidas das lamelas; por isso são os sítios reativos mais abundantes (MANGONI, 2014). Os sítios AlO-H e SiO$\mathrm{H}$ podem interagir através de ligações de hidrogênio para adsorver espécies catiônicas ou moléculas acumuladas nas interfaces. Nesses grupos $\mathrm{OH}$ pode haver a dissociação do íon $\mathrm{H}+$, gerando carga negativa nas arestas, essas cargas geradas são dependentes do pH do meio, como ilustrado na FIG.12 (MC BRIDE, 1994). Devido ao caráter anfótero dos grupos silanol e aluminol, é possível incorporar espécies catiônicas presentes nas soluções aquosas variando o pH.

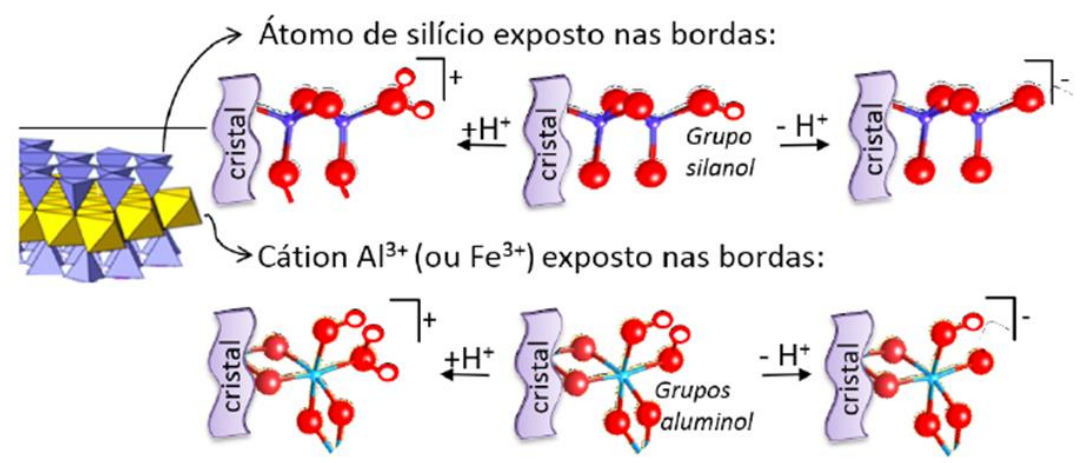

FIGURA 12 - Sítios ativos dos argilominerais: Grupo silanol e aluminol. Fonte: (MANGONI, 2014). 
Este tipo de sítios ativos (grupos silanol) são os predominantes nos argilominerais tipo paligorsquita e sepiolita, os quais apresentam nanotubos naturais devido à sua peculiar estrutura fibrilar. Para estas argilas, foram encontrados trabalhos em condições de $\mathrm{pH}$ variando de $\approx 0$ até 9 (ESTEBANCUBILLO, PINA-ZAPARDIEL, et al., 2008; 2010).

De acordo com o intervalo de $\mathrm{pH}$ considerado, identificam-se grupos silanol protonados $(0<\mathrm{pH}<3)$, neutros $(3<\mathrm{pH}<5,5)$ e desprotonados $(5,5<\mathrm{pH}<8,5)$.

Outras reações podem ocorrer além da protonação/ desprotonação dos grupos silanol e aluminol. Por exemplo, em valores de $\mathrm{pH}$ inferiores a 4 e superiores a 11, observa-se solubilização dos octaedros de alumínio e magnésio. Em pH superior a 9-10, observa-se que os tetraedros de silício começam a solubilizar gerando íons silicato em solução (DUCA, GABORIAUDA e THOMA, 2005).

À medida que o $\mathrm{pH}$ diminui, o próton começa a competir com o cátion na região interlamelar ou em outros lugares accessíveis, promovendo reação de troca iônica.

A presença de sítios ativos é de fundamental importância nos processos de sorção como podem ser a troca iônica, a adsorção e a estabilização coloidal, entre outros (GOMES, 1988; AGUIAR, NOVAES e GUARINO, 2002).

\subsubsection{Troca iônica nos argilominerais}

A troca catiónica é um processo pelo qual um cátion ligado a um sítio ativo sobre uma superfície é substituído por um cátion presente na solução. Tanto nas zeólitas como nos fiilossilicatos, os cations trocáveis podem estar localizados tanto nas superfícies externas como nas superfícies internas (BERGAYA, LAGALY e VAYER, 2013).

A capacidade de troca iônica é uma característica importante dos argilominerais, pois resulta no desequilíbrio de suas cargas elétricas e pode influenciar fortemente suas propriedades físicas e químicas.

Define-se essa capacidade como o número de íons trocados por unidade de massa ou volume do trocador. Para capacidade de troca catiônica (CTC), a unidade recomendada pela IUPAC é miliequivalentes por $100 \mathrm{~g}(\mathrm{mEq} / 100 \mathrm{~g})$ (BERGAYA, LAGALY e VAYER, 2013). 
A CTC dos argilominerais em geral está relacionada com a carga existente nas camadas. A medida da CTC é equivalente à carga da camada somente quando todos os cátions de compensação da rede podem ser trocados.

A troca iônica depende tanto das propriedades do trocador quanto das propriedades dos íons submetidos à troca. A afinidade de um íon por um trocador, isto é, a "trocabilidade" iônica depende principalmente de três fatores (BRANDÃO, 2011).

- Carga elétrica do íon: quanto maior a carga do íon, maior será a força com que ele é atraído pelos grupos funcionais de carga oposta, ou seja, maior será a sua capacidade de troca. Também será mais difícil removê-lo no processo de regeneração do trocador.

- Raio iônico: no caso de íons equivalentes, a magnitude de seus raios é decisiva para sua capacidade de troca, pois entre cátions de mesma valência, a seletividade aumenta com o raio iônico.

- Raio de hidratação: quanto maior o volume do íon, menor será o seu campo elétrico em solução e, menor será o seu grau de hidratação (CASES, BEREND, et al., 1997). Para uma mesma série de íons, o raio hidratado é geralmente inversamente proporcional ao raio iônico do elemento (AGUIAR, NOVAES e GUARINO, 2002).

Na FIG. 13, pode-se observar que o tamanho dos raios iônicos das espécies catiônicas hidratadas descritas são afirmações estatísticas sobre uma população de íons, os quais podem mudar em extensão da hidratação em escalas de tempo muito curto. Assim, os valores representados graficamente são medias ao longo do tempo do raio hidratado de muitos cátions da mesma espécie em condições de pressão e temperatura determinadas $\left(P=1\right.$ atm e $\left.T=25^{\circ} \mathrm{C}\right)$ (STRAWN, BOHN e O'CONNOR, 2015). 


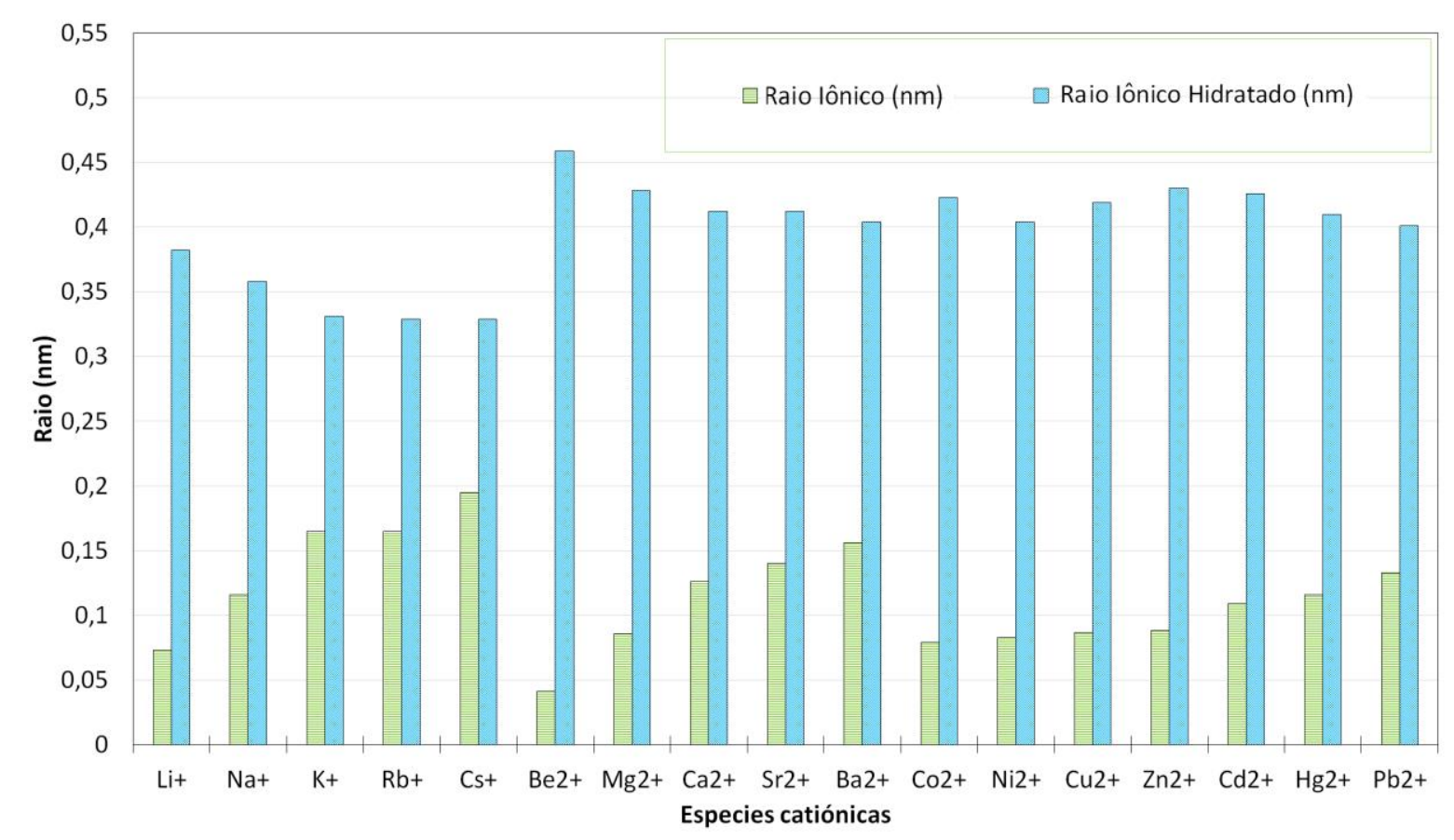

FIGURA 13 - Raio iônico $(R)$ Vs raio iônico hidratado $\left(R_{H}\right)$. Fonte: (STRAWN, BOHN e O'CONNOR, 2015)

A capacidade de troca devido as ligações rompidas aumenta com a diminuição do tamanho de partículas e pode, portanto, ser aumentada por qualquer tratamento que conduza a formação de novas superfícies. $\mathrm{O} \mathrm{pH}$ de uma argila resulta, em parte, da natureza dos íons trocáveis presentes. Não é possível preparar uma argila 100\% monoiônica em hidrogênio, visto que ocorre a degradação do retículo cristalino pela penetração de íons-hidrogênio na camada octaédrica com a perda de alumínio. (SOUZA-SANTOS, 1989).

A troca iônica pode ser aniônica se os íons trocados forem ânions e catiônica se os íons trocados forem cátions. Neste trabalho a possível reação iônica envolvida é catiônica.

\subsubsection{Efeitos da radiação nos argilominerais}

Os argilominerais tem diferentes susceptibilidades frente à radiação, apresentando danos que variam ao longo de várias ordens de grandeza da irradiação de 100 KGy para Brucita e Caulinita, 1000 KGy para montmorillonita e paligorsquita e $30000 \mathrm{KGy}$ para gibsita. Dos argilominerais testados a caulinita 
apresentou o maior número defeitos induzidos pela radiação e foi o argilomineral mais susceptível à dose de radiação (GORE e SNAPE, 2014).

Os efeitos da radiação ionizante (partículas alfa, beta e raios gama) sobre filossilicatos foram estudados por meio de irradiação gama artificial. Concluindo que radiações ionizantes com moderada energia (intervalo de $\mathrm{MeV}$ ) não afetam a estrutura dos argilominerais estudados para doses experimentais abaixo de $10^{5} \mathrm{~Gy}$ (ALLARD, BALAN e CALAS, 2013).

\subsection{Paligorsquita}

A paligorsquita é um argilomineral que possui um grande interesse para aplicações industriais devido ao conjunto de suas propriedades físicas e químicas tais como área superficial elevada, microporosidade, alta cristalinidade e estrutura fibrosa na forma de nanotubos naturais, que irão refletir na sua textura característica, comportamentos de sorção, propriedades ópticas como também no comportamento coloidal, reológico e catalítico (FERNÁNDEZ, TIMÓN, et al., 2013).

A paligorsquita é utilizada pela indústria como veículo de fertilizantes, pesticidas, fármacos e purificador de água. Na indústria petrolífera ela é utilizada como fluido de perfuração. Também tem aplicações como absorvente de óleos, graxas e "pet littler" (ALMEIDA e CHAVES, 1995; VIEIRA-COELHO, SOUZASANTOS e SANTOS, 2007)

Anualmente, o consumo de paligorsquita está estimado em 1.000.000 Toneladas, onde os Estados Unidos (EEUU) são os maiores produtores (93\% da produção mundial). O valor comercial do argilomineral irá depender de sua pureza local, variando entre 250-450 US \$/Tonelada (2007) (VIEIRA-COELHO, SOUZASANTOS e SANTOS, 2007).

Desde o ponto de vista histórico e cultural, a paligorsquita foi usada por antigas civilizações na fabricação do destacado e misterioso pigmento hibrido conhecido como "azul maya" (FERNÁNDEZ, TIMÓN, et al., 2013).

Os principais depósitos de paligorsquita, no Brasil, estão situados no município de Guadalupe-PI, distribuídos por uma área de cerca de 700 km². Embora já se tenham realizados vários trabalhos de pesquisa com bons resultados visando principalmente um maior e melhor aproveitamento desse argilomineral, tem se observado que a comercialização deste material no estado de Piauí é muito 
pequena (LUZ e ALMEIDA, 2008). Segundo informações do Distrito do DNPM (2004), apenas uma empresa estava em atividade, testando o mercado da paligorsquita para clarificação de ceras, óleos vegetais e minerais e sebo bovino (LUZ e ALMEIDA, 2008).

\section{Características físicas e químicas}

A paligorsquita é um argilomineral hidratado de hábito fibroso, sendo um filossilicato alumino magnésico do tipo 2:1.

A paligorsquita apresenta uma estrutura cristalina constituída por duas camadas tetraédricas ligadas por uma camada octaédrica central por meio de oxigênios comuns. A estrutura fibrosa destes argilominerais é devida à inversão das camadas tetraédricas a cada 4 posições, nas quais os tetraedros invertidos das bordas compartem um mesmo oxigênio. Ou seja, os oxigênios basais do ápice das folhas tetraédricas são invertidos periodicamente em relação às bases tetraédricas o que dá lugar a formação de nanotubos naturais estruturais, resultando em uma estrutura semelhante até certo ponto à das zeólitas. Na estrutura da paligorsquita pode haver algumas substituições isomórficas, como por exemplo, nas camadas octaédricas que geralmente estão ocupadas por $\mathrm{Mg}^{2+}$, podem ser trocados pelos cátions $\mathrm{Al}^{3+}$ ou $\mathrm{Fe}^{3+}$ e nas camadas tetraédricas que podem trocar os cátions de $\mathrm{Si}^{4+}$ por cátions de $\mathrm{Al}^{3+}$.

Das cinco posições octaédricas que existem na estrutura da paligorsquita apenas quatro das posições estão ocupadas, consequentemente a paligorsquita aparece como sendo um argilomineral intermediário entre dioctaédrico e trioctaédrico, como pode se apreciar na FIG.14b, a estrutura idealizada da célula unitária da paligorsquita, cujas dimensões espaciais são de 1,27 x 1,79 nm, está representada na FIG.14a (GALAN e SINGER, 2011).

A estrutura cristalina é balanceada eletricamente, e existem diferentes fórmulas químicas teóricas propostas na literatura, onde a primeira foi proposta por Bradley (BRADLEY, 1940) correspondendo a $\mathrm{Si}_{8} \mathrm{Mg}_{5} \mathrm{O}_{20}(\mathrm{OH})_{2}\left(\mathrm{H}_{2} \mathrm{O}\right)_{4} 4\left(\mathrm{H}_{2} \mathrm{O}\right)$. Drits e Sokolova realizaram outra proposta para a fórmula química teórica da paligorsquita como $\mathrm{Si}_{8} \mathrm{Mg}_{2} \mathrm{Al}_{2} \mathrm{O}_{20}(\mathrm{OH})_{2}\left(\mathrm{H}_{2} \mathrm{O}\right)_{4} 4\left(\mathrm{H}_{2} \mathrm{O}\right)$ (DRITS e SOKOLOVA, 1971). No entanto, estas propostas não se ajustavam com paligorsquitas de diversas origens. Finalmente, a fórmula proposta por Bailey (BAILEY, 1980) na EQ.5 e que expressa 
a molécula em função do grau de substituição dos cátions das camadas octaédrica e tetraédrica respeitando a variação química no argilomineral. Atualmente é a mais utilizada para calcular a fórmula química da paligorsquita, quando esta não se ajusta às formulas teóricas anteriormente citadas.

$$
\left(\mathrm{Si}_{8-x} \mathrm{R}^{3+}{ }_{x}\right)\left(\mathrm{Mg}_{5-y-z} \mathrm{R}^{3+}{ }_{y} \vee z\right) \mathrm{O}_{20}(\mathrm{OH})_{2}\left(\mathrm{H}_{2} \mathrm{O}\right)_{4} \cdot 4\left(\mathrm{H}_{2} \mathrm{O}\right) \cdot \mathrm{E}^{2+}(x-y+2 z) / 2
$$

$\mathrm{Na} E Q .5, \mathrm{R}^{3+}$ representa comumente os cátions de $\mathrm{Al}^{3+} \mathrm{e} \mathrm{Fe}^{3+} \mathrm{e} \mathrm{V} \cdot$ representa a vacante octaédrica. $\mathrm{E}^{2+}$ representa os cátions trocáveis existentes nos canais ou nanotubos e essa quantidade $(x-y+2 z) / 2$, assume-se igual ao excesso de carga correspondente a metade da célula unitária.

SUÁREZ, GARCÍA-ROMERO, et al. (2007), propuseram uma classificação dos diferentes tipos existentes de paligorsquita baseada tanto na porcentagem de alumínio na composição química do argilomineral como nos valores de difração correspondes à reflexão $\mathrm{d}_{200}$.

De acordo com os deslocamentos da célula unitária, a estrutura cristalina da paligorsquita pode ser ortorrômbica (grupo espacial Pnmb), monoclínica (grupo espacial C2/m) ou uma mistura entre as duas (FERNÁNDEZ, TIMÓN, et al., 2013).

Estudos mostram que as moléculas de água presentes no interior dos canais da paligorsquita interagem com a estrutura de duas formas distintas (FERNÁNDEZ, TIMÓN, et al., 2013). A primeira a ser identificada foi a água ligada aos cátions de magnésio (localizados na posição M1 da FIG.14.b) atendendo às necessidades de coordenação. O segundo tipo foi identificado como água zeolítica, e interage tanto com as moléculas de água coordenadas na estrutura como com as presentes nas folhas tetraédricas. Além disso, existem grupos hidroxilos (identificados como grupos $\mathrm{OH}^{-}$na FIG.14.a) no interior dos sítios octaédricos. Portanto, cada célula unitária cristalina contém normalmente oito moléculas de água (F/G.14). Quatro moléculas de água estão ligadas duas a duas nos cátions de magnésio situados nas bordas da camada octaédrica (FIG.14.a) e quatro moléculas de água zeolitica localizadas dois a dois dentro dos canais internos em ambos os lados da célula unitária (FIG.14.a). A água zeolítica é perdida facilmente a uma temperatura relativamente baixa (inferior a $120^{\circ} \mathrm{C}$ ). As duas moléculas pertencentes aos grupos hidroxilos ligadas aos cátions dioctaédricos (Al,Fe) ou trioctaédricos ( $\mathrm{Mg}$ ), 
(localizados na posição M2 da FIG.14.b), localizadas no interior da célula unitária (FIG.14.a) e a agua estrutural localizada nas bordas são perdidas na temperatura de 300 a $550^{\circ} \mathrm{C}$.

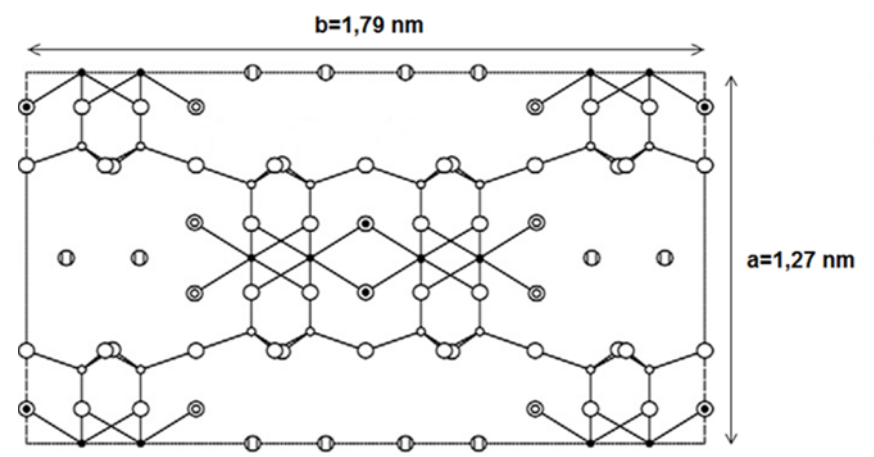

$$
\begin{array}{ll}
\odot \mathrm{H}_{2} \mathrm{O} & \text { (Água zeolítica) } \\
\odot \mathrm{OH}_{2} & \text { (Água estrutural) } \\
\odot \mathrm{OH}^{-} & \text {(Grupo hidroxilo) } \\
\circ \mathrm{O} & \text { (Oxigênio) } \\
\circ \mathrm{Si} & \text { (Silicio) }
\end{array}
$$

a

- Mg/Al (Magnésio ou alumínio)

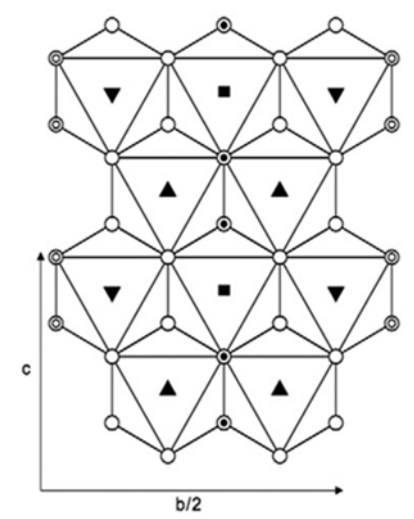

b

V M1 Octaedro ocupado por Mg

- M2 Octaedro ocupado por Al

- M3 Octaedro com vacante $\mathrm{V}^{*}$

FIGURA 14 - a) Estrutura da paligorsquita (duas células unitárias) projetada no plano (001) e b) disposição octaédrica. Fonte: (YAN, LIU, et al., 2012).

A perda da água estrutural a temperaturas superiores a $300^{\circ} \mathrm{C}$ irá provocar uma mudança da estrutura durante a qual produz-se o colapso ou "folding" estrutural por rotação em torno de um eixo das ligações Si-O-Si que ligam as camadas tetraédricas invertidas da paligorsquita (PREISINGER, 1963).

GONZÁLEZ, PESQUERA e BENITO (1993), examinaram as modificações estruturais da paligorsquita por análise térmica sob vácuo. Os autores afirmaram que o colapso ou "folding" estrutural começa na temperatura de $125^{\circ} \mathrm{C}$, temperatura na qual a microporosidade diminui. O "folding" estrutural é reversível até à temperatura de $300^{\circ} \mathrm{C}$. Acima desta temperatura de tratamento térmico a modificação estrutural é irreversível. Na FIG.15 apresenta-se o esquema estrutural antes e após o colapso estrutural dos nanotubos na temperatura de tratamento acima de $300^{\circ} \mathrm{C}$. 


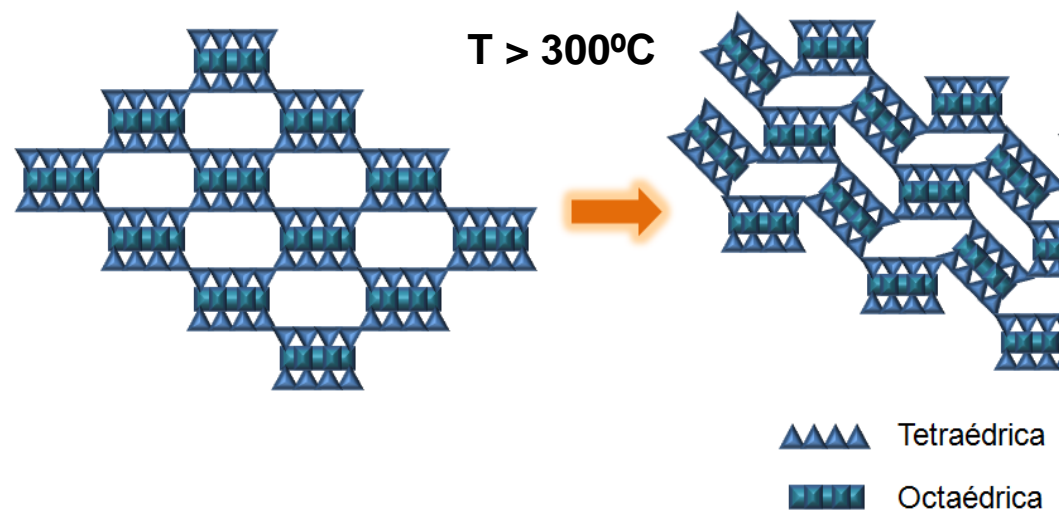

FIGURA 15 - Esquema do colapso ou "folding" estrutural da paligorsquita durante o tratamento térmico (T). Fonte: (GONZÁLEZ, PESQUERA e BENITO, 1993).

BOUDRICHE, CALVET, et al. (2012) estudaram as modificações estruturais da paligorsquita após tratamento térmico no intervalo 100-1000드, e identificaram modificações em duas faixas de temperatura: Nas temperaturas inferiores a $500^{\circ} \mathrm{C}$ produz-se a perda de massa devido a uma saída das moléculas de água (superficial, zeolítica e estrutural) e das hidroxilas ligadas na estrutura, preservando a morfologia fibrilar, apesar de um rearranjo estrutural. Nas temperaturas superiores a $500^{\circ} \mathrm{C}$, ocorre uma coalescência das partículas (sinterização) e, como consequência, a partir desta temperatura ocorre a redução da área e volume dos microporos e também da área superficial específica. Em altas temperaturas, novas fases cristalinas aparecem e a morfologia fibrilar é afetada significativamente devido à completa fusão das fibras da paligorsquita.

Deste modo é patente que o tratamento térmico na paligorsquita produz um colapso ou "folding" estrutural irreversível que pode ser favorável para a aplicação proposta neste trabalho.

As propriedades nanoestruturais da paligorsquita combinadas com a sua elevada área superficial específica, tem como resultado um argilomineral com potencial uso como material sorvente (CHEN, ZHAO e WANG, 2007).

A sorção pode ser produzida por interação de espécies catiônicas com determinados sítios ativos da superfície e/ou pela troca catiônica. Existem três possíveis sítios ativos presentes na paligorsquita (JONES e GALAN, 1988; SERRATOSA, 1979), relatados como:

- Oxigênios na camada tetraédrica,

- Mg coordenado na água nas bordas da camada octaédrica e 
- Grupos silanol (SiO-H).

As características estruturais e morfológicas da paligorsquita determinam a presença de um grande número de terminações de sílica na superfície externa da camada tetraédrica das fibras. Devido à ruptura da ligação Si-O-Si, esta é compensada com uma carga residual aceitando um próton $\left(\mathrm{M}^{\mathrm{x}}\right)$ ou uma hidroxila $(\mathrm{OH})$, para formar grupos silanol $(\mathrm{SiO}-\mathrm{H})$. Estes grupos ocorrem em intervalos de aproximadamente $0,5 \mathrm{~nm}$ ao longo dos nanotubos que formam as fibras da paligorsquita, e a sua quantidade pode ser relacionada com as dimensões dos nanotubos ou com imperfeições na rede cristalina (SERRATOSA, 1979), como se observa na FIG.16.

A modificação por ativação ácida de argilominerais fibrilares, do tipo 2:1, como é o caso da paligorsquita, produz a remoção dos cátions presentes na camada octaédrica gerando uma quantidade maior de sítios ativos na forma de grupos silanol. Os grupos silanol localizados nos nanotubos ou canais internos do argilomineral, podem ser gerados sem, contudo, provocar a ruptura das ligações Si-O-Si da camada tetraédrica, contribuindo para um número maior de sítios ativos, sem que ocorram modificações estruturais significativas (ESTEBAN-CUBILLO, 2007).

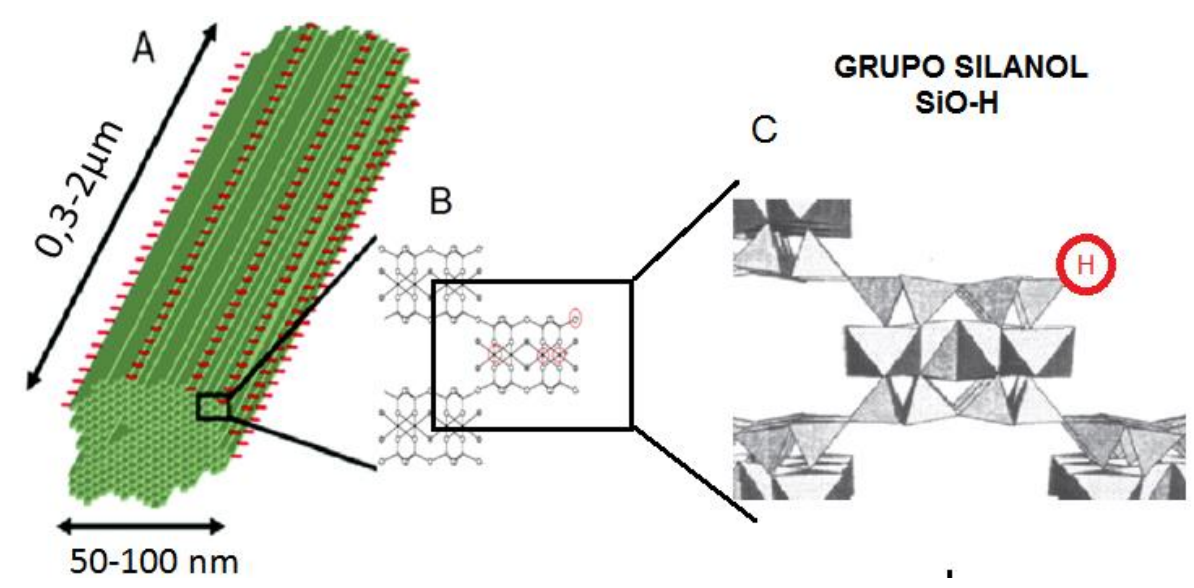

FIGURA 16 - Localização dos grupos silanol na paligorsquita (Autor)

Todos estes sítios podem ser seletivos e específicos para a sorção de determinados cátions ou moléculas presentes em soluções aquosas de diferentes efluentes. 
O mecanismo de sorção de diferentes cátions metálicos tanto para paligorsquita como para a sepiolita, gera controvérsia na literatura e foi investigado por diferentes autores (ALVAREZ-AYUSO e GARCIA-SANCHEZ, 2003; ESTEBAN-CUBILLO, 2007; LAZAREVIĆ, JANKOVIĆ-ČASTVAN, et al., 2007; CHEN, ZHAO e WANG, 2007; WANG, CHEN e WANG, 2007; FAN, SHAO, et al., 2009; CHEN, GAU e LU, 2011).

ALVAREZ-AYUSO e GARCÍA-SÁNCHEZ (2003) estudaram a sorção seletiva de vários metais ( $\mathrm{Pb}, \mathrm{Cu}, \mathrm{Zn}$ e $\mathrm{Cd}$ ) em função da facilidade de hidrólise dos mesmos, sugerindo os grupos silanol como os principais atores na sorção destes metais pela paligorsquita. Também ressaltam que a predominância na sorção como esperado ocorre nas bordas da estrutura devido a maior facilidade de rompimento das ligações Si-O.

ESTEBAN-CUBILLO (2007) estudou o papel da lixiviação dos cátions de magnésio na estabilidade estrutural da sepiolita no processo de ativação ácida e na incorporação de cátions presentes em solução. $O$ autor demonstrou que para tratamentos fortemente ácidos por curtos períodos de tempo é possível incorporar cátions no interior dos nanotubos da sepiolita, sorvidos nos sítios ativos (grupos silanol) gerados pela lixiviação dos cátions de magnésio da estrutura, mantendo a estabilidade estrutural. O resultado mais expressivo deste estudo foi à obtenção das condições favoráveis da ativação ácida da sepiolita para a incorporação do $\mathrm{Ni}^{2+}$ em concentrações similares ao $\mathrm{Mg}^{2+}$ lixiviado mantendo intacta a sua estrutura original.

CHEN, ZHAO e WANG (2007) também comprovaram a eficiência da ativação em meio ácido para a ativação da paligorsquita nos estudos de remoção de $\mathrm{Cu}$ (II) em solução aquosa, sem se preocupar pela integridade estrutural.

BOUDRICHE, CALVE, et al. (2015) obtiveram a máxima capacidade de sorção do $\mathrm{Pb}^{2+}$ pela paligorsquita submetida a prévio tratamento de moagem. Este resultado foi atribuído à quebra da estrutura fibrosa da paligorsquita ( $\mathrm{Si}-\mathrm{O}-\mathrm{Si}$ ), devido ao intenso tratamento de moagem o que, provavelmente, gerou um maior número de sítios ativos na forma de grupos silanol proporcionando uma maior capacidade da sorção. Por outro lado, FRINI-SRASRA e SRASRA (2010), ao avaliarem os parâmetros que envolviam a adsorção do $\mathrm{Pb}(\mathrm{II})$ na paligorsquita natural e modificada por ativação ácida com $\mathrm{HCl}$, observaram que a ativada apresentou melhor capacidade de sorção. 
Deste modo é patente que a ativação ácida é o método mais indicado para a ativação dos argilominerais fibrilares promovendo uma maior área superficial específica e maior número de sítios ativos do material que são as duas importantes características que requerem os materiais usados como sorventes.

É possível realizar o tratamento de ativação ácida para melhorar as propriedades físicas e químicas da paligorsquita, visando a incorporação de radionuclídeos de interesse nos nanotubos que a compõem. Contudo, um dos resultados pode ser a destruição parcial da estrutura (GALAN, 1996; NETO, ALMEIDA e CARVALHO, 1993). Esta destruição parcial da estrutura possivelmente poderá impedir a incorporação e posterior imobilização dos radionuclídeos no interior dos nanotubos naturais ativados embora a morfologia fibrosa seja preservada.

O objetivo deste estudo é viabilizar a técnica de ativação de superfície para preparar os nanotubos naturais da paligorsquita para o processo de incorporação de radionuclídeos presentes em efluentes nucleares.

As condições de tratamento para a ativação irão depender da origem do material (CORMA, MIFSUD e SANZ, 1987; ZHANG, WANG, et al. ,2010; OLIVEIRA, ACCHAR, et al., 2013; FRINI-SRASRA e SRASRA, 2010; MYRIAM, SUÁREZ-BARRIOS e MARTIN-POZAS, 1998), do tipo e concentração do ácido (ZHANG, WANG, et al., 2010) e da temperatura e do tempo de ativação (CORMA, MIFSUD e SANZ ,1987; XAVIER, SANTOS, et al., 2014; OLIVEIRA, ACCHAR, et al., 2013; SANCHEZ-DELRIO, MARTINETTO, et al., 2006; FRINI-SRASRA e SRASRA, 2010; MYRIAM, SUÁREZ-BARRIOS e MARTIN-POZAS, 1998).

Para este trabalho a integridade estrutural da paligorsquita e, portanto, dos nanotubos naturais que a compõem, é uma das condições mais importantes a considerar, e ela é influenciada tanto pela severidade do ataque ácido, como pela temperatura e tempo de permanência em solução ácida (CORMA, MIFSUD e SANZ ,1987; ZHANG, WANG, et al., 2010; XAVIER, SANTOS, et al., 2014; OLIVEIRA, ACCHAR, et al., 2013; FRINI-SRASRA e SRASRA, 2010; MYRIAM, SUÁREZBARRIOS e MARTIN-POZAS, 1998). 


\subsubsection{Efeitos da radiação na paligorsquita}

A paligorsquita é praticamente inerte aos efeitos das radiações ionizantes. Nos estudos realizados por PUSHKAREVA, KALINICHENKO, et al. (2002) não foram observadas mudanças estruturais para a faixa de radiação ionizante $\left(10^{7} \mathrm{~Gy}\right)$

\subsection{Mecanismo de incorporação e imobilização dos cátions}

Há vários materiais e mecanismos utilizados para a incorporação e imobilização de metais (HUSSIN, AROUA e DAUD, 2011).

ALVAREZ-AYUSO e GARCIA-SANCHEZ (2003) sugeriram que a troca catiônica do Mg estrutural existente nas bordas da camada octaédrica é o principal mecanismo que envolve a sorção de $\mathrm{Cd}$ e $\mathrm{Zn}$ nos argilominerais fibrilares. O raio iônico hidratado similar dos cátions envolvidos (Mg, Cd e $\mathrm{Zn}$ ) foi estabelecido como condição necessária para a troca. Este fato também foi reportado por ESTEBANCUBILLO (2007), propondo o autor o tamanho do raio hidratado como condição necessária para a escolha dos metais a incorporar na sepiolita ativada. Por outro lado, LAZAREVIć, JANKOVIć-ČASTVAN, et al. (2007) sugeriram que uma maior eletronegatividade dos metais a incorporar esta ligada com uma maior tendência do íon para formar complexos na superficie dos argilominerais fibrilares, indicando que íons mais estaveis na solução tem uma afinidade menor para sorção específica em uma superficie sólida, embora os raios hidratados dos cátions envolvidos sejam similares.

Os valores de carga iônica, raio iônico, potencial iônico, eletronegatividade e raio hidratado dos cátions de magnésio $\left(\mathrm{Mg}^{2+}\right)$, níquel $\left(\mathrm{Ni}^{2+}\right)$ e estrôncio $\left(\mathrm{Sr}^{2+}\right)$ estão representados na $T A B .7$.

TABELA 7 - Carga iônica, raio iônico, potencial iônico, eletronegatividade e raio hidratado dos cátions de magnésio $\left(\mathrm{Mg}^{2+}\right)$, níquel $\left(\mathrm{Ni}^{2+}\right)$ e estrôncio $\left(\mathrm{Sr}^{2+}\right)$.

\begin{tabular}{cccccc}
\hline Cátion & $\begin{array}{c}\text { Carga } \\
\text { iônica }(\mathbf{Z})\end{array}$ & $\begin{array}{c}\text { Raio iônico } \\
(\boldsymbol{R}, \boldsymbol{n m})\end{array}$ & $\begin{array}{c}\text { Potencial } \\
\text { iônico } \\
(\mathbf{Z} / \boldsymbol{R})\end{array}$ & Eletronegatividade & $\begin{array}{c}\text { Raio } \\
\text { hidratado } \\
\left(\boldsymbol{R}_{\boldsymbol{H}}, \boldsymbol{n m}\right)\end{array}$ \\
\hline $\mathrm{Mg}^{2+}$ & +2 & 0,086 & 23,255 & 1,31 & 0,428 \\
$\mathrm{Ni}^{2+}$ & +2 & 0,083 & 24,096 & 1,91 & 0,404 \\
$\mathrm{Sr}^{2+}$ & +2 & 0,140 & 14,285 & 0,95 & 0,412 \\
\hline
\end{tabular}


O mecanismo de incorporação de radionuclídeos nos nanotubos naturais ativados da paligorsquita visando a integridade da estrutura, seguido do colapso estrutural para imobilizar os radionuclídeos previamente incorporados, não foi observado na literatura. Este mecanismo foi observado apenas para a sepiolita (ESTEBAN-CUBILLO, 2007), o qual é relatado no presente capítulo.

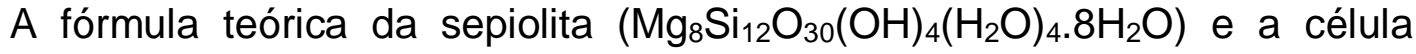
unitária são semelhantes às da paligorsquita, apresentado ambos argilominerais características físicas e químicas similares.

Em estudos realizados com a paligorsquita e a sepiolita (WANG, CHEN e WANG, 2007; CHEN, ZHAO e WANG, 2007; ESTEBAN-CUBILLO, 2007), observou-se que ao diminuir o $\mathrm{pH}$ para valores inferiores a 3 por meio do tratamento ácido, produz-se a dissolução dos cátions de magnésio que envolvem a estrutura dos nanotubos naturais, dando lugar a sítios ativos na forma de grupos silanol, em concordância com a EQ.6.

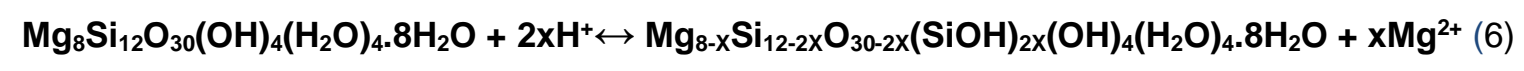

ESTEBAN-CUBILLO (2007), afirmou que uma vez gerados os sítios ativos na sepiolita e protonados os grupos silanol (em $\mathrm{pH}$ fortemente ácido), o metal a incorporar pode ser adicionado na solução que contém o argilomineral em suspensão, em concentrações molares similares ao $\mathrm{Mg}$ anteriormente lixiviado. Após completa homogeneização da solução, o pH deve ser elevado de forma controlada, produzindo-se tanto a incorporação dos cátions metálicos na estrutura na forma de silicatos (formando complexos superficiais com os grupos silanol), segundo a $E Q .7$, como a precipitação do metal em forma de hidróxidos ou oxihidróxidos. Este último fato é indesejável e ocorre sempre que o pH da solução seja maior que o pH de precipitação do metal.

$\mathrm{Mg}_{8-x} \mathrm{Si}_{12-2 x} \mathrm{O}_{30-2 x}(\mathrm{SiOH})_{2 x}(\mathrm{OH})_{4}\left(\mathrm{H}_{2} \mathrm{O}\right)_{4.8 H_{2}} \mathrm{O}+\mathrm{xM}^{2+} \leftrightarrow \mathrm{Mg}_{8-x} \mathrm{M}_{x} \mathrm{Si}_{12} \mathrm{O}_{30}(\mathrm{OH})_{4}\left(\mathrm{H}_{2} \mathrm{O}\right)_{4.8 \mathrm{H}_{2}} \mathrm{O}(7)$

A incorporação dos cátions na sepiolita em forma de silicatos é devida fundamentalmente ao caráter anfótero dos grupos silanol nos quais ocorre a protonação em meio ácido, formando complexos catiônicos (positivos), e também 
desprotonação em meio básico, formando complexos aniônicos (negativos) (CHEN, ZHAO e WANG, 2007; ESTEBAN-CUBILLO, PINA-ZAPARDIEL, et al., 2008).

O esquema representado na FIG.17, ilustra o comportamento de formação dos grupos silanol em função do $\mathrm{pH}$ do meio. Os grupos silanol comportam-se como centros ativos de Lewis onde tem lugar a sorção das espécies catiônicas presentes na solução.

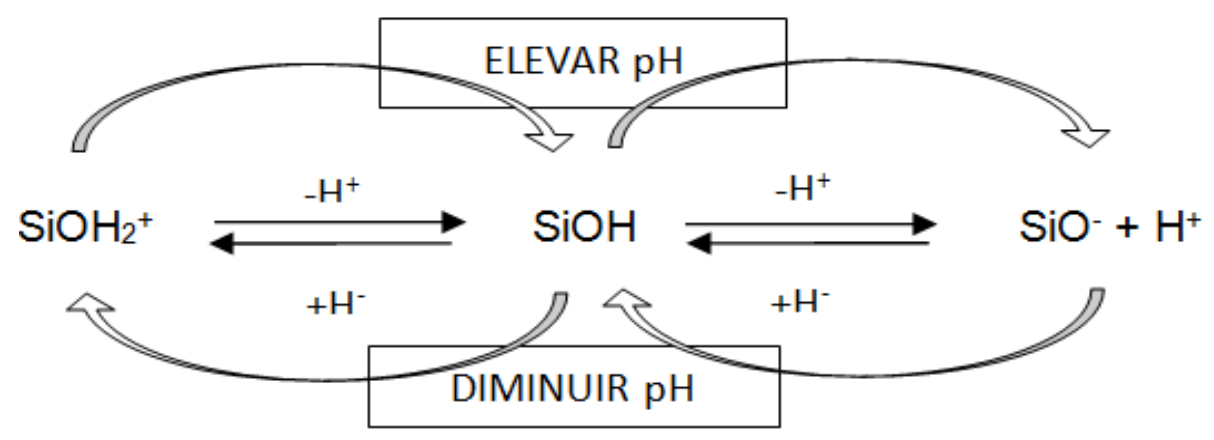

FIGURA 17 - Caráter anfótero do grupo silanol (Autor).

Uma vez introduzidos os metais na sepiolita ativada, realiza-se um tratamento térmico em condições de temperatura suficiente para se favorecer a reação e ativar mecanismos que tem como consequência o colapso da estrutura devido possivelmente à eliminação de água estrutural. Este tipo de reação termodinamicamente favorecida resulta em uma reestruturação da rede cristalina da sepiolita (ESTEBAN-CUBILLO, 2007).

De este modo, com o tratamento térmico adequado a estrutura da sepiolita, colapsa irreversivelmente, imobilizando no seu interior os cátions metálicos incorporados nas camadas octaédricas da matriz (ESTEBAN-CUBILLO, 2007).

Até o presente não se encontrou na literatura estudos de ativação e colapso estrutural dos nanotubos de paligorsquita e em especial para a paligorsquita extraída das lavras nacionais visando por estes processos potencializar sua aplicação como sorventes de radionuclídeos presentes em efluentes nucleares. 


\section{MATERIAIS E MÉTODOS}

O desenvolvimento experimental busca adequar os nanotubos naturais da paligorsquita para a incorporação de radionuclídeos em concentrações similares aos cátions de magnésio lixiviados da estrutura, por meio de um processo de ativação ácida superficial otimizado, sem produzir modificações estruturais significativas, para posteriormente serem imobilizados por colapso estrutural via tratamento térmico.

\subsection{Materiais de partida}

Para este estudo utilizou-se:

- Paligorsquita obtida a partir de uma lavra da região do estado de Piauí (Brasil), no município de Guadalupe. O material previamente moído e classificado, foi caracterizado como recebido sem nenhum tratamento adicional.

- Os radionuclídeos foram simulados utilizando:

- Nitrato de estrôncio $\left(\mathrm{Sr}\left(\mathrm{NO}_{3}\right)_{2}(\mathrm{PA}),>99.0 \%\right.$, Sigma-Aldrich)

○ Cloreto de Niquel ( $\mathrm{NiCl}_{2}$ (PA), >99.0\%, Sigma-Aldrich)

- Demais reagentes:

- Ácido Clorídrico, $\mathrm{HCl}$ (P.A) 37\%, Synth

- Hidróxido de Sódio (NaOH P.A, Synth)

\subsection{Técnicas de caracterização}

\subsubsection{Análise química}

\subsubsection{Florescência de Raios X por Dispersão de Energia (FRX-EDS)}

A técnica semiquantitativa de espectrometria de fluorescência de raios $X$ por dispersão de energia, FRX-EDS foi utilizada para determinar a composição química 
do argilomineral como recebido, do argilomineral purificado e dos argilominerais modificados durante o processo de desenvolvimento. As amostras para análise foram pulverizadas $(<210 \mu \mathrm{m})$ e secas $150^{\circ} \mathrm{C}$ por $24 \mathrm{~h}$ e os resultados forma expressos em óxidos.

O equipamento utilizado foi o espectrofotômetro marca Shimadzu, modelo EDX 720, baseado no Método de Parâmetros Fundamentais.

\subsubsection{Espectrometria de Emissão Atômica por Plasma Acoplado Indutivamente (ICP-OES)}

A técnica de ICP-OES baseia-se na emissão ótica de átomos excitados do elemento em estudo. Como fonte de excitação utiliza-se plasma de argônio. $O$ plasma, por definição, é um gás parcialmente ionizado, que fornece altas temperaturas (5500 a $10000 \mathrm{~K}$ ) e alta densidade eletrônica ( 1 a $\left.3 \cdot 10^{15} \mathrm{e} \cdot \mathrm{cm}^{-3}\right)$, com energia suficiente para quebrar as ligações e ionizar a maioria dos elementos metálicos e alguns não metálicos. (BOSTELMANN, 2006; KRUG, NÓBREGA e OLIVEIRA, 2004)

A técnica que possui capacidade multielementar sequencial rápida ou simultânea, com alta sensibilidade e precisão (NORDBERG, FOWLER, et al., 2007).

As amostras foram analisadas no equipamento Vista MPX simultâneo ICPOES (Agilent, Australia) equipado com tocha de vista axial, software versão 4.1.0., nebulizador Meinhard tipo K, câmara de nebulização concêntrica e detector de estado sólido.

\subsubsection{Distribuição granulométrica por espalhamento de Feixe de Laser}

A análise granulométrica por espalhamento laser permite determinar a distribuição dos diâmetros médios das partículas ou de aglomerados, utilizando os fenômenos de difração e difusão de um feixe de laser ao atravessar o meio onde se encontram as partículas em suspensão (EWINGS, 1972). O laser apresenta uma potência de $15 \mathrm{~mW}$, possibilitando tempo de medidas tipicamente de 1 a 2 minutos (BROOKHAVEN INSTRUMENTS CORPORATION, 1995). 
A distribuição do tamanho das partículas da amostra do argilomineral como recebido foi obtido em um analisador de potencial Zeta (Zetâmetro) marca Brookhaven, modelo ZetaPALS (Phase Analysis Ligth Scattering). As suspensões do argilomineral diluído em meio aquoso na faixa de 0,0001\% a 1\% em volume a temperatura ambiente com $\mathrm{pH}=8,2$ foram dispersas em ultra-som e analisadas utilizando o software Mas Option/ZetaPlus Sizing.

\subsection{3 Área superficial específica (BET), área e volume dos microporos e parâmetros físicos relacionados}

A área superficial é uma das propriedades físicas mais importantes da paligorsquita, especialmente quando usada como sorvente de metais pesados e moléculas (CHEN e WANG, 2009).

A técnica BET foi utilizada para analisar a área superficial específica do argilomineral como recebido, purificado e modificado durante o processo de desenvolvimento da matriz.

Todas as amostras foram mantidas a $150^{\circ} \mathrm{C}$ por $24 \mathrm{~h}$ em estufa para remover a humidade e os possíveis contaminantes adsorvidos antes de realizar as análises das amostras.

A área de superfície específica foi determinada usando o método de adsorção gasosa BET (Bruaner, Emmett e Teller), por meio da adsorção - desorção de Nitrogênio a $77 \mathrm{~K}$. O método consiste em determinar o volume ocupado por uma monocamada de gás inerte na superfície das partículas. A área de superfície especifica por unidade de massa ( $\mathrm{S}_{\mathrm{BET}}$ ) é expressa pela EQ.8 (BRUNAUER et al., 1938).

$$
S_{B E T}=\frac{N_{A} V_{m} A_{m}}{V_{m o l} M} \quad\left(m^{2} \cdot g^{-1}\right)
$$

Onde: $\mathrm{N}_{\mathrm{A}}=$ Número de Avogadro (6,23·1023 átomos)

$A m$ = Área ocupada por uma molécula de gás adsorvido $\left(16,2 \cdot 10^{-20} \mathrm{~m}^{2} \quad \mathrm{~N}_{2}\right)$

$\mathrm{Vm}=$ Volume da molécula de gás adsorvida $\left(\mathrm{cm}^{3}\right)$

Vmol = Volume de $1 \mathrm{~mol}$ de gás a temperatura ambente $\left(\mathrm{cm}^{3}\right)$

$\mathrm{M}=$ massa $\mathrm{da}$ amostra $(\mathrm{g})$ 
Para determinar a área de superfície especifica $\left(\mathrm{S}_{\mathrm{BET}}\right)$ das amostras foi utilizado um analisador BET da marca Micromeritics, modelo ASAP2010 (USA).

A partir do valor da área de superfície especifica $\left(S_{\mathrm{BET}}\right)$ determinou-se o tamanho médio das partículas da amostra utilizando-se a EQ.9 (REED, 1995). Nesta relação, considera-se que as partículas apresentam morfologia esférica e homogênea.

$$
d_{B E T}=\frac{6}{\rho S_{B E T}} \cdot(\mu m)
$$

Onde: $\mathrm{d}_{\mathrm{BET}}=$ diâmetro médio da partícula $(\mu \mathrm{m})$;

$\rho=$ Densidade teórica do material $\left(\mathrm{g} \cdot \mathrm{cm}^{-3}\right)$;

$\mathrm{S}_{\mathrm{BET}}=$ Área de superfície específica da partícula $\left(\mathrm{m}^{2} \cdot \mathrm{g}^{-1}\right)$.

Segundo SUÁREZ-BARRIOS e GARCÍA-ROMERO (2012), os microporos (0-2 nm) existentes na sepiolita e na paligorsquita são devidos a porosidade estrutural característica dos argilominerais fibrilares que são compostos por nanotubos naturais, também chamados de canais internos, e os mesoporos (2-50 $\mathrm{nm})$ e macroporos $(50 \mathrm{~nm}<)$ existentes são característicos da textura devido à tendência na aglomeração destes argilominerais.

Os relatos existentes na literatura (ZHANG, WANG, et al., 2010; MYRIAM, SUÁREZ-BARRIOS e MARTIN-POZAS, 1998), expõem que a variação dos parâmetros de área e volumem do microporo, podem ser devidos a dissolução excessiva dos cátions presentes nas camadas octaédrica e tetraédrica em função da intensidade das condições de ativação ácida. Deste modo podemos nos basear nos relatos existentes na literatura para justificar a necessidade de avaliação da integridade estrutural dos nanotubos por meio destes parâmetros após o tratamento de ativação ácida para as diferentes condições selecionadas em este trabalho.

Os valores obtidos das curvas isotérmicas de adsorção-dessorção de $\mathrm{N}_{2}$ foram usados para o cálculo da área superficial especifica $\left(\mathrm{S}_{\mathrm{BET}}\right)$, diâmetro médio ( $\left.\mathrm{d}_{\text {médio }}\right)$ e volume total dos poros $\left(\mathrm{V}_{\text {TOTAL }}\right)$, pelo método $\mathrm{BET}$. A área externa $\left(\mathrm{S}_{\text {ext }}\right)$, área de microporo $\left(S_{\text {micro }}\right)$ e volume de microporo $\left(\mathrm{V}_{\text {micro }}\right)$, foram calculadas pelo método t-plot (Harkins e Jura) representado na FIG.20. O volume de mesoporo $\left(V_{\text {meso }}\right)$ e o diâmetro pico dos mesoporos ( $\left.\mathrm{dp}_{\text {meso }}\right)$ foram calculados pelo método 
DH-plot, e finalmente, diâmetro pico dos microporos ( $\left.\mathrm{dp}_{\text {micro }}\right)$ foi calculado pelo método MP-Plot (ALLEN, 1997; WEBB e ORR, 1997).

A área superficial é a soma da área superficial externa e da área dos microporos, como representado na $E Q .10$ e o volume total e a soma do volume dos mesoporos e do volume dos microporos, EQ.11.

$$
\begin{gathered}
S_{\text {BET }}=S_{\text {ext }}+S_{\text {micro }} \\
V_{\text {TOTAL }}=V_{\text {meso }}+V_{\text {micro }}
\end{gathered}
$$

A partir dos dados obtidos nas isotermas de adsorção-dessorção, e relacionando o volume adsorvido com a espessura calculada a partir da $E Q .12$ de Harkins e Jura $(H-J)$ pode-se obter uma reta de regressão, $y=m \cdot x+y_{0}, \operatorname{com} R^{2} \approx 1$, para os valores de t compreendidos entre 3 e $5 \mathrm{~A}$, e deste modo, calcular os parâmetros de volume e área de microporo como representado na $F / G$. 18, na qual está ilustrado o procedimento de cálculo do volume de microporo, da área externa e da área do microporo da amostra de paligorsquita purificada $(P P)$.

$$
H-J, t(A)=\left[\frac{13,90}{0,034-\log \left(p / p_{0}\right)}\right]^{1 / 2}
$$
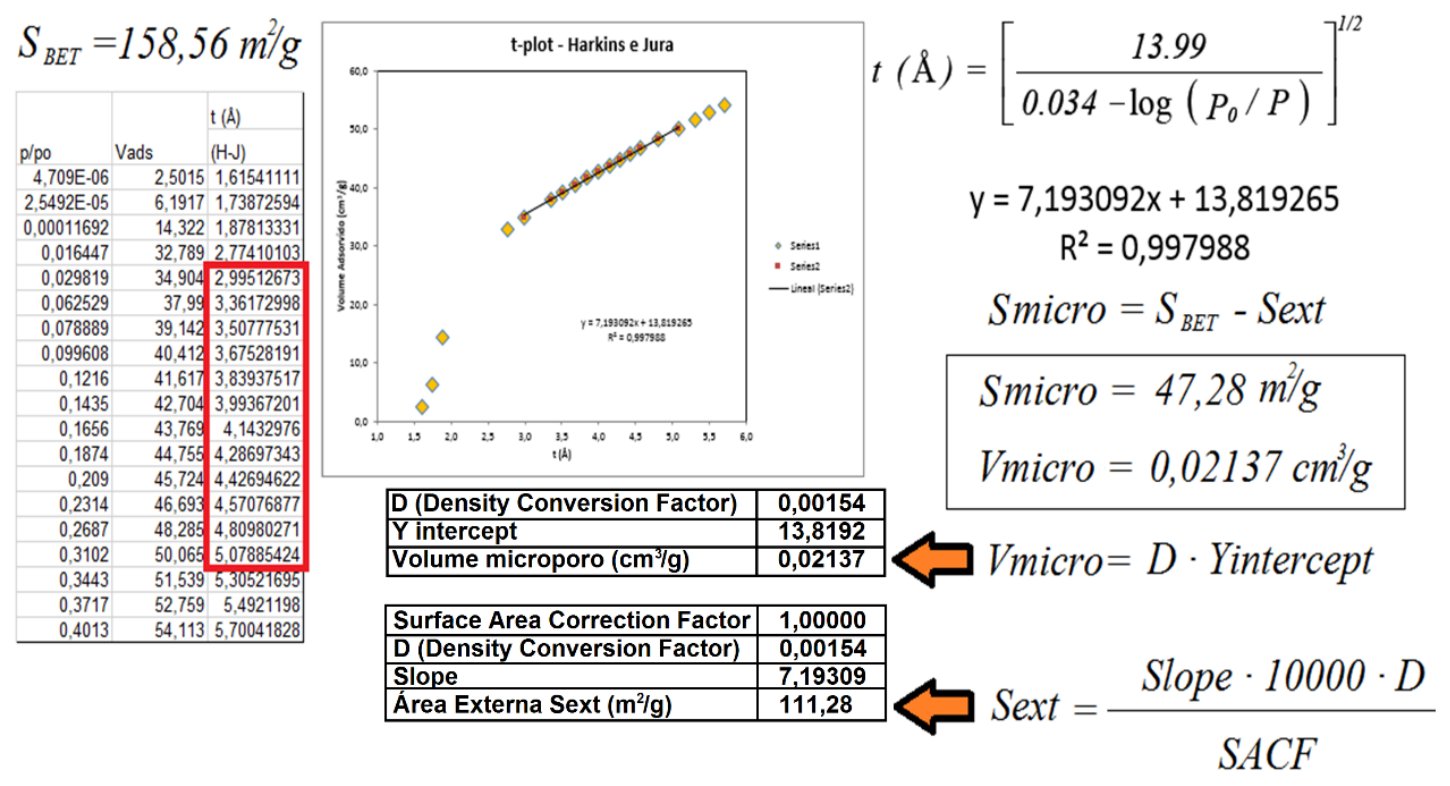

FIGURA 18 - Representação do cálculo do volume e área do microporo e da área externa da paligorsquita purificada (PP) pelo método " $\mathrm{t}$ - plot" baseado na equação de Harkins e Jura (H-J). 


\subsubsection{Difração de Raios X (DRX)}

A técnica de DRX foi utilizada para determinar as fases cristalinas presentes e as modificações estruturais produzidas pelo processo de desenvolvimento da matriz cerâmica. Esta técnica proporciona uma grande quantidade de informação sobre a cristalinidade e estrutura dos materiais implicados no processo de ativação ácida.

O equipamento utilizado neste estudo foi o difratômetro Rigaku (Multiflex,

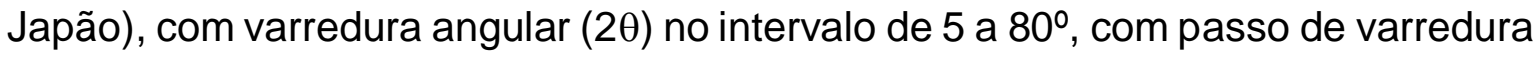
$(\Delta 2 \Theta)$ de $2^{\circ} \mathrm{min}^{-1}$ e fonte $\mathrm{Cu} \mathrm{Ka}$. Para identificar as amostras estudadas, utilizou-se o banco de dados do software Crystoallographica Search- Match (Versão 2.1.1.1. Oxford Cryosystems). As fichas cristalográficas usadas para identificar as principais reflexões da paligorsquita, do quartzo e da dolomita foram as fichas localizadas na base de dados do Centro Internacional de Dados de Difração (ICDD) de $\mathrm{n}^{\circ} 031$ 0783, 065-0466 e 084-1208, respectivamente

Existem diferentes estruturas identificadas e propostas para a paligorsquita: paligorsquita ortorrômbica, paligorsquita monoclínica e a mistura das duas estruturas posteriores.

CHISHOLM (1992) mostrou que as intensidades relativas de algumas reflexões determinadas podem ser usadas como discriminação, uma vez que cada modelo espacial possui reflexões específicas.

\subsubsection{Análise Térmica Diferencial e Termo Gravimétrica (ATD/TG)}

Na literatura mostraram que a estrutura da paligorsquita está composta por dois tipos de água diferentes e grupos hidroxilos, e a desidratação das fibras produz o colapso estrutural em função da temperatura e do tempo. As análises termogravimétricas (ATG) foram utilizadas para determinar as alterações na massa do argilomineral em função da temperatura e do tempo. As analises térmicas diferenciais (ATD), foram utilizadas para identificar as possíveis mudanças estruturais no material em função da temperatura e do tempo (CHENG, YANG, et al., 2011; BOUDRICHE, CALVET, et al., 2012)

As análises ATG/ATD dos argilominerais foram realizadas no analisador termogravimétrico marca Setaram (S60/38336, França), com termopar de Pt/Rth, 
nas seguintes condições: velocidade de aquecimento $10^{\circ} \mathrm{C} \cdot \mathrm{min}^{-1}$ até a temperatura de $900^{\circ} \mathrm{C}$.

\subsubsection{Espectroscopia no infravermelho com Transformada de Fourier (FT-} IR)

A espectrometria na região do infravermelho identifica espécies químicas e principalmente grupos funcionais como resultado da interação entre os modos de vibração e a energia relativa ao feixe da fonte de infravermelho incidente (LOPEZ e MARQUEZ, 2002).

$\mathrm{Na} T A B .8$ encontram-se representadas as principais bandas de adsorção e os modos de vibração característicos da paligorsquita identificados na literatura (YAN, LIU, et al., 2012).

TABELA 8 - Bandas de adsorção e dos modos de vibração característicos da paligorsquita identificados na literatura (YAN, LIU, et al., 2012).

\section{Referencias Literatura}

\begin{tabular}{|c|c|c|c|}
\hline Modo de vibração & Banda $\left(\mathrm{cm}^{-1}\right)$ & Modo de vibração & Banda $\left(\mathrm{cm}^{-1}\right)$ \\
\hline${ }^{\mathrm{a}} \mathrm{V}_{\mathrm{s}}, \mathrm{MgO}_{6}$ octaédrico & 433 & ${ }^{\mathrm{d}} \mathrm{V}_{\text {as }}, \mathrm{Si}-\mathrm{O}_{2}-\mathrm{Si}$ & 1120 \\
\hline${ }^{\mathrm{b}} \delta, \mathrm{O}-\mathrm{Si}-\mathrm{O}$ & 478 & ${ }^{\mathrm{d}} \mathrm{V}_{\mathrm{as}}, \mathrm{Si}-\mathrm{O}_{1}-\mathrm{Si}$ & 1196 \\
\hline$\delta$, Si-O-Si, & 510 & $\delta, \mathrm{H}_{2} \mathrm{O}$ & 1630 \\
\hline $\mathrm{V}_{\mathrm{s}}, \mathrm{AlO}_{6}$ octaédrico & 580 & $\delta,{ }^{\mathrm{e}} \mathrm{OH}_{2}$ & 1653 \\
\hline $\mathrm{V}_{\mathrm{s}},{ }^{\mathrm{c}} \mathrm{H}_{2} \mathrm{O}-\mathrm{Mg}-\mathrm{H}_{2} \mathrm{O}$ & 647 & $\begin{array}{c}\mathrm{Vs}, \mathrm{H}_{2} \mathrm{O} \text { ligada ao } \\
\text { oxigênio em Si-O-Al }\end{array}$ & 3260 \\
\hline $\begin{array}{l}\mathrm{V}_{\mathrm{s}}, \mathrm{Si}-\mathrm{O}-\mathrm{Mg} / \\
\mathrm{V}_{\mathrm{s}}, \mathrm{Si}-\mathrm{O}-\mathrm{Al}\end{array}$ & 672 & $\mathrm{~V}_{\mathrm{s}}, \mathrm{H}_{2} \mathrm{O}$ & $3403-3431$ \\
\hline$\delta, \mathrm{Al}-\mathrm{OH}-\mathrm{Al}$ & 910 & $\mathrm{~V}_{\mathrm{s}}, \mathrm{OH}_{2}$ & $3525 / 3525$ \\
\hline${ }^{\mathrm{d}} \mathrm{V}_{\mathrm{as}}, \mathrm{Si}-\mathrm{O}_{\mathrm{nb}}-\mathrm{Mg}(\mathrm{VI})$ & 987 & $\mathrm{~V}_{\mathrm{s}}, \mathrm{Al}-\mathrm{OH}-\mathrm{Fe}^{3}$ & 3580 \\
\hline${ }^{\mathrm{d}} \mathrm{V}_{\text {as }}, \mathrm{Si}-\mathrm{O}_{3}-\mathrm{Si}$ & 1033 & $\mathrm{~V}_{\mathrm{s}}, \mathrm{Al}-\mathrm{OH}-\mathrm{Al}$ & 3615 \\
\hline${ }^{\mathrm{d}} \mathrm{V}_{\mathrm{as}}, \mathrm{SiO}_{4}$ & 1088 & $\mathrm{~V}_{\mathrm{s}}, \mathrm{Mg}_{3}-\mathrm{OH}$ & $3686 / 3700$ \\
\hline
\end{tabular}

a $\bigvee_{s}$, vibração de estiramento simétrica, ${ }^{b} \delta$, vibração da deformação ${ }^{c} \mathrm{H}_{2} \mathrm{O}$ Zeolitica e $\mathrm{H}_{2} \mathrm{O}$ absorvida superficial (fissisorvida), ${ }^{d} \mathrm{~V}_{\mathrm{as}}$, vibração de estiramento assimétrica e ${ }^{\mathrm{e}} \mathrm{OH}_{2}$, água ligada.

Esta técnica foi utilizada para: 
- Determinar espécies químicas e grupos funcionais característicos dos argilominerais presentes na amostra,

- Identificar possíveis alterações estruturais produzidas na matriz cerâmica durante o processo de desenvolvimento quando submetida à ataques ácidos e tratamentos térmicos.

As amostras pulverizadas (<210 $\mu \mathrm{m})$, foram dispersas em $\mathrm{KBr}$ (Merck P.A.) e pastilhadas em prensa a vácuo. O equipamento utilizado foi o modelo Nexus 870 FTIR da marca Thermo Nicolet (thermo Fisher Scientific, Waltham, Estados Unidos).

\subsubsection{Capacidade de troca catiônica (CTC)}

A técnica foi baseada no método de acetato de amônio (SHAH, SILVAVALENZUELA, et al., 2013). O equipamento utilizado para determinação da Capacidade de Troca de Cátions (CTC) foi um destilador de nitrogênio (ou Kjeldahl) modelo TE-036/Plus (Marconi Company). O procedimento foi realizado a seguir: Pesou-se em balança analítica, 5,0 gramas da amostra e a colocou em um erlenmeyer contendo $200 \mathrm{~mL}$ de acetato de amônio $3 \mathrm{M}(\mathrm{pH}=7,2)$, em seguida manteve-se a solução sob agitação constante por 12 horas. Após este procedimento, centrifugou-se e coletou-se a amostra, que foi lavada com álcool etílico para retirar o excesso de acetato de amônio, em seguida centrifugou-a novamente. O material recolhido foi transferido para um vidro de relógio e permaneceu em estufa à $75^{\circ} \mathrm{C}$ por 24 horas para secagem. Pesou-se em balança analítica 1,5 gramas do material seco, que foi desagregado manualmente em almofariz e transferido para um frasco de Kjeldahl adicionando-se $50 \mathrm{~mL}$ de água destilada e 3 gotas de fenolftaleína e acoplou-se o frasco ao equipamento. Adicionou-se hidróxido de sódio a $50 \%$ até que a solução contida no frasco de Kjeldahl tornou-se rósea. Após isto, injetou-se vapor ao tubo, ocorrendo a liberação da amônia, trocando-se com os cátions de sódio. $\mathrm{O} \mathrm{NH}_{3}$ desprendido é passado por um destilador e é então recebido em um erlenmeyer contendo $50 \mathrm{~mL}$ de ácido bórico a 4\% com indicador misto. O ácido bórico com indicador que, no início apresentava coloração vermelha, adquire cor verde à medida que vai recebendo 
$\mathrm{NH}_{3}$. Encerrada a destilação, retirou-se o erlenmeyer do sistema e procedeu-se a titulação da solução com ácido clorídrico $0,1 \mathrm{~N}$ até obter a coloração vermelha. $\mathrm{O}$ volume (em $\mathrm{mL}$ ) gasto na titulação foi utilizado para determinar o valor da CTC utilizando-se a EQ.13:

$$
C T C=\frac{100 \cdot N \cdot V_{H C l}}{m}
$$

Onde, m é a massa da amostra em gramas,

$\mathrm{N}$ é a Normalidade do ácido de referência $(\mathrm{HCl})$,

$\mathrm{V}_{\mathrm{HCl}}$, é o volume de ácido $(\mathrm{HCl})$ utilizado para a titulação.

A CTC da amostra foi calculada em duplicado e a média de dois valores foi feita como uma CTC (mEq/100g) da amostra.

\subsubsection{Microscopia Eletrônica de Varredura (MEV)}

A microscopia eletrônica de varredura, MEV, foi utilizada para a análise morfológica do argilomineral como recebido, purificado e acompanhamento durante os processos de desenvolvimento da matriz.

As análises morfológicas dos argilominerais foram realizadas utilizando-se o microscópio marca Philips, modelo XL 30. Na preparação o argilomineral foi disperso em meio aquoso, por ultrassom e uma pequena alíquota foi transferida para um porta amostras polido. Antes das analises, as amostras foram recobertas com ouro em sputtering.

\subsubsection{Microscopia Eletrônica de Transmissão com detector de Espectroscopia de Energia Dispersa (MET-EDS)}

O estudo morfológico das amostras de paligorsquita purificada, ativada, tratada termicamente e com metal $(\mathrm{Ni})$ incorporado foi realizado por microscopia eletrônica de transmissão (MET-EDS), por meio do equipamento JEM 2100 - marca Jeol com detector de espectroscopia de energia dispersiva (EDS) acoplado, operando a $200 \mathrm{KeV}$ com limite de resolução de $2,5 \mathrm{~nm}$ ponto a ponto. 
As micrografias foram obtidas depositando uma gota da suspensão do pó em acetona, dispersa em ultrassom sobre uma grade de Cu de $3 \mathrm{~mm}$ de diâmetro.

A grade que é recoberta por uma fina camada de polímero para retenção do pó, recebe posteriormente grade e amostra um recobrimento de carbono por sputtering. A camada de carbono depositada deve ser o suficientemente larga como para proteger ao polímero da elevada energia do feixe de elétrons e evitar a sua degradação.

\subsection{Processo de Incorporação de Radionuclídeos em Nanotubos Naturais Ativados}

O processo utilizado para o desenvolvimento da matriz e posterior incorporação e retenção de radionuclídeos na estrutura da mesma, foi denominado de Processo de Incorporação de Radionuclídeos em Nanotubos Naturais Ativados (PIRNan). A incorporação é realizada por sorção, fundamentada nas propriedades anfóteras dos grupos silanol gerados após ativação dos nanotubos e possivelmente por mecanismos de troca iônica. O tratamento térmico posterior à sorção dos radionuclídeos contribui para a retenção e imobilização dos mesmos por colapso estrutural.

A ativação ácida da superfície que envolve os nanotubos naturais da paligorsquita tem como objetivo a lixiviação do maior número de cátions de magnésio presentes na camada octaédrica sem modificar a estrutura dos nanotubos, aumentando a área superficial específica. A lixiviação de forma controlada destes cátions, poderá gerar um número equivalente de sítios ativos na forma de grupos silanol adequados para a incorporação dos cátions presentes em efluentes radioativos. Uma vez que os cátions radioativos presentes na solução sejam incorporados nos nanotubos ativados, o estudo da viabilidade de imobilização será realizado por meio do tratamento térmico em condições adequadas. O processo tem por base o procedimento de incorporação de cátions metálicos na estrutura da sepiolita (ESTEBAN-CUBILLO, 2007).

O processo experimental para incorporar radionuclídeos em nanotubos naturais ativados foi dividido em cinco etapas: 


\section{Etapa 1 - Caracterização do material como recebido}

A paligorsquita foi recebida previamente moída e classificada em paineira (ABNT 200 mesh, abertura $75 \mu \mathrm{m}$ ), e foi estudada utilizando-se as técnicas: $D R X$, FRX-EDS, Distribuição granulométrica por retroespalhamento de feixe de lasermétodo Zeta-PAALS, BET, FT-IR, MEV, CTC e ATD/TG.

\section{Etapa 2 - Purificação}

A paligorsquita em sua forma natural pode estar associada a outros minerais e impurezas. Nas análises preliminares exploratórias realizadas para o material como recebido $(P N)$ utilizando-se a $D R X, F T$-IR e $F R X-E D S$, identificou-se a presença de dolomita $\left(\mathrm{CaMg}\left(\mathrm{CO}_{3}\right)_{2}\right)$ e quartzo $\left(\mathrm{SiO}_{2}\right)$ como impurezas minerais. Pelo que foi realizado o tratamento de purificação adequado para a remoção da dolomita, sem produzir modificações estruturais do argilomineral.

A EQ.14 exibe a reação de dolomita, com ácido clorídrico, ocorrendo já a partir de $\mathrm{pH}$ em torno de $4-5$ durante 48h (BERGAYA e LAGALY, 2013).

$$
4 \mathrm{HCl}+\mathrm{CaMg}\left(\mathrm{CO}_{3}\right)_{2} \rightarrow \mathrm{Mg}^{2+}+\mathrm{Ca}^{2+}+4 \mathrm{Cl}^{-}+2 \mathrm{CO}_{2}+2 \mathrm{H}_{2} \mathrm{O}
$$

Como os cátions octaédricos (Mg, Fe e $\mathrm{Al}$ ) presentes na paligorsquita são removidos em condições fortemente ácidas $(\mathrm{pH}<3)$, a dolomita pode ser facilmente eliminada controlando-se o pH da solução durante o processo de purificação.

Utilizando-se ácido clorídrico (2M) fez-se ajuste em pH 4,0 e, preparou-se uma suspensão de paligorsquita na concentração de 15\% em massa, mantendo o valor do $\mathrm{pH}$ inicial com ajuste do ácido adicionado. Sob forte agitação por $48 \mathrm{~h}$ e repouso de $1 \mathrm{~h}$, separou-se o precipitado por filtração e lavagens com água deionizada foram realizados até a solução procedente do filtrado da purificação dar negativo na reação do cloro com $\mathrm{AgNO}_{3}$. Após seco em estufa a $150^{\circ} \mathrm{C}$ por 24 horas, a paligorsquita purificada $(P P)$ foi caracterizada por meio das seguintes técnicas: DRX, FRX-EDS, FT-IR, ATD/TG, BET, MEV e MET. 


\section{Etapa 3 - Tratamento térmico}

Os tratamentos térmicos foram realizados em forno tipo mufla, nas temperaturas previamente definidas em função dos resultados das análises de ATD/TG. Estas análises fornecem importantes informações na verificação da temperatura otimizada de colapso estrutural irreversível. Ressaltando que este comportamento de colapso estrutural contribui na retenção e imobilização dos radionuclídeos simulados a incorporar. O estudo do tratamento térmico será caracterizado segundo os resultados obtidos das amostras de paligorsquita tratadas nas temperaturas de 300,550 e $800^{\circ} \mathrm{C}$ por três horas por meio das técnicas de $D R X, F T-I R, B E T$ e TEM.

\section{Etapa 4 - Ativação ácida}

O estudo do papel dos cátions de magnésio no processo de ativação ácida para promoção de sítios ativos (grupos silanol) na superfície dos nanotubos sem modificar a estrutura, foi realizado variando-se a concentração de ácido utilizada, a temperatura e o tempo de permanência sob agitação. Os valores estabelecidos para cada condição de ensaio encontram-se na TAB.9. Todos os ensaios foram realizados em capela, com aquecimento em chapa aquecedora sob agitação magnética com acompanhamento de temperatura com termômetro $\left( \pm 2,5^{\circ} \mathrm{C}\right)$, na proporção sólido-líquido $1: 10 \mathrm{~g} \cdot \mathrm{mL}^{-1}$.

Em todos os ensaios, após o tempo estipulado, afim de se verificar a eficiência do mesmo, a misturas foram separadas por filtração a vácuo, utilizandose papel filtro quantitativo em um frasco kitasato. A amostra foi lavada repetidas vezes com agua deionizada até a solução procedente do filtrado dar negativo na reação do cloro com $\mathrm{AgNO}_{3}$, o filtrado foi seco em estufa a $150^{\circ} \mathrm{C}$ por um tempo de 24 horas e as amostras ativadas secas foram submetidas às caracterizações por FRX-EDS, DRX, FT-IR, BET, MEV e MET.

A condição otimizada de ativação ácida com maior remoção de cátions de magnésio sem produzir modificações estruturais foi denominada PA. 
TABELA 9 - Condições experimentais de ativação ácida da paligorsquita.

\begin{tabular}{cccc}
\hline CONDIÇÃO & $\begin{array}{c}\text { Concentração molar de } \\
\text { HCl }\left(\mathbf{m o l} \cdot \mathbf{L}^{-1}\right)\end{array}$ & Temperatura $\left({ }^{\circ} \mathbf{C}\right)$ & Tempo (h) \\
\hline $\boldsymbol{P 1}$ & 3 & 60 & 1 \\
$\boldsymbol{P 2}$ & 3 & 60 & 4 \\
$\boldsymbol{P 3}$ & 3 & 90 & 1 \\
$\boldsymbol{P 4}$ & 3 & 90 & 4 \\
\hline $\boldsymbol{P 5}$ & 6 & 60 & 1 \\
$\boldsymbol{P 6}$ & 6 & 60 & 4 \\
$\boldsymbol{P 7}$ & 6 & 90 & 1 \\
$\boldsymbol{P 8}$ & 6 & 90 & 4 \\
\hline $\boldsymbol{P 9}$ & 9 & 60 & 1 \\
$\boldsymbol{P 1 0}$ & 9 & 60 & 4 \\
$\boldsymbol{P 1 1}$ & 9 & 90 & 1 \\
$\boldsymbol{P 1 2}$ & 9 & 90 & 4 \\
\hline $\boldsymbol{P 1 3}$ & 9 & 60 & 1 \\
$\boldsymbol{P 1 4}$ & 12 & 60 & 4 \\
$\boldsymbol{P 1 5}$ & 12 & 90 & 1 \\
$\boldsymbol{P 1 6}$ & 12 & 90 & 4 \\
\hline
\end{tabular}

Etapa 5 - Incorporação e imobilização dos cátions radioativos simulados $\mathrm{Sr}^{2+}$ e $\mathrm{Ni}^{2+}$ nos nanotubos ativados

Uma vez realizada a purificação do material (etapa 2) e conhecidas as condições otimizadas de colapso estrutural por tratamento térmico (etapa 3) e de ativação ácida (PA) (etapa 4), nesta etapa se estudará a incorporação dos radionuclídeos nos sítios ativos gerados na estrutura dos nanotubos:

A paligorsquita purificada foi colocada em solução na condição otimizada de ativação ácida PA e, uma vez a temperatura da solução atingiu a temperatura ambiente, adicionou-se uma solução de $80 \mathrm{~mL}$ contendo os sais de $\mathrm{Sr}\left(\mathrm{NO}_{3}\right)_{2}$ ou de $\mathrm{NiCl}_{2}$, em concentrações de níquel ou estrôncio superiores à percentagem em massa de magnésio removido, respectivamente. Nesta etapa juntamente com a ativação tem lugar a reação teórica apresentada na EQ.15. 
$\mathrm{Mg}_{2} \mathrm{Al}_{2} \mathrm{Si}_{8} \mathrm{O}_{20}(\mathrm{OH})_{2}\left(\mathrm{H}_{2} \mathrm{O}\right)_{4} \cdot 4 \mathrm{H}_{2} \mathrm{O}+2 \mathrm{xH}^{+} \leftrightarrow \mathrm{Mg}_{2-x} \mathrm{Al}_{2} \mathrm{Si}_{12-2 x} \mathrm{O}_{20-2 x}(\mathrm{SiOH})_{2 x}(\mathrm{OH})_{4}\left(\mathrm{H}_{2} \mathrm{O}\right)_{4} \cdot 4 \mathrm{H}_{2} \mathrm{O}+\mathrm{xMg}^{2+}(15)$ Onde: $x$, representa a percentagem de cátions de magnésio removidos na ativação ácida por célula unitária.

Posteriormente, elevou-se $\circ \mathrm{pH}$ com adição de $\mathrm{NaOH}, 1 \mathrm{M}$ até $\circ \mathrm{pH}$ de equilíbrio da espécie catiônica adicionada, evitando a precipitação dos mesmos na forma de hidróxidos ou oxihidróxidos, segundo o pH de distribuição da espécie como ilustrado na FIG.19.
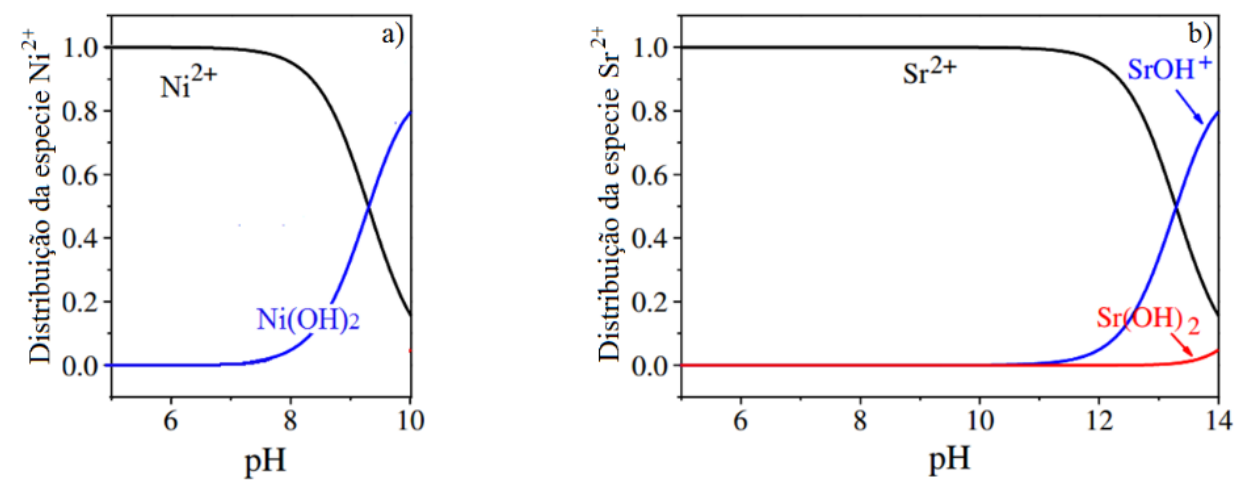

FIGURA 19 - Distribuição da espécie $\mathrm{Ni}^{2+}$ (a) e $\mathrm{Sr}^{2+}$ (b) em função do $\mathrm{pH}$ (Adaptadas de SHEIKHHOSSEINI et al., 2014 e QIU et al., 2013, respectivamente)

O objetivo de manter o pH de equilíbrio da espécie catiônica em solução é incorporar os cátions radioativos presentes, nos sítios ativos gerados durante a ativação ácida, tendo lugar a reação teórica apresentada na EQ.16.

\footnotetext{
$\mathrm{Mg}_{2-x} \mathrm{Al}_{2} \mathrm{Si}_{12-2 x} \mathrm{O}_{20-2 x}(\mathrm{SiOH})_{2 x}(\mathrm{OH})_{4}\left(\mathrm{H}_{2} \mathrm{O}\right)_{4 \cdot} \cdot 4 \mathrm{H}_{2} \mathrm{O}+\mathrm{xM}^{2+} \leftrightarrow \mathrm{Mg}_{2-x} \mathrm{Al}_{2} \mathrm{M}_{\mathrm{x}} \mathrm{Si}_{8} \mathrm{O}_{20}(\mathrm{OH})_{4}\left(\mathrm{H}_{2} \mathrm{O}\right)_{4} \cdot 4 \mathrm{H}_{2} \mathrm{O}$ (16) Onde: $\mathrm{M}$, representa o cátion radioativo a incorporar ( $\mathrm{Ni}$ ou $\mathrm{Sr}$ ).
}

Com base nos estudos de máxima capacidade de sorção e equilíbrio da espécie catiônica em solução realizados na literatura (SHEIKHHOSSEINI et al., 2014; QIU et al., 2013; ESTEBAN-CUBILLO, 2007; BRANDÃO, 2011), decidiu-se optar para este trabalho, o estabelecimento do $\mathrm{pH}_{\text {final }}=6$ de equilíbrio para a sorção do níquel e pH final $=7$ de equilíbrio para a sorção do estrôncio.

$\mathrm{O}$ acompanhamento do processo de sorção dos cátions de $\mathrm{Ni}^{2+}$ e $\mathrm{Sr}^{2+}$ na paligorsquita foi realizado extraindo-se alíquotas de $2 \mathrm{~mL}$ para $\mathrm{t}_{1}=0 \mathrm{~min}, \mathrm{t}_{2}=15 \mathrm{~min}$, $t_{3}=60 \mathrm{~min}, t_{4}=120 \mathrm{~min}, t_{5}=240 \mathrm{~min}$ e $t_{6}=1440 \mathrm{~min}$ (só para o Sr). As alíquotas foram extraídas do sobrenadante da solução sem agitação, após aguardar 5 minutos para decantação do sólido. 
A suspensão foi filtrada a vácuo e lavou-se o sólido com água deionizada até a solução procedente do filtrado dar negativo na reação do cloro com $\mathrm{AgNO}_{3} \mathrm{O}$ sólido secou-se a $150^{\circ} \mathrm{C}$ durante 24 horas e as diferentes alíquotas foram analisadas por análise químico ICP-OES, para determinar a quantidade de estrôncio e níquel remanescentes.

Os experimentos de sorção anteriores foram realizados em batelada usando agitação magnética constante a temperatura ambiente.

Os nanotubos naturais ativados com o metal incorporado foram tratados termicamente na condição otimizada de colapso estrutural em forno tipo mufla. Os sólidos obtidos foram caracterizados pelas técnicas FRX-EDS, DRX e MET-EDS. Para poder identificar o níquel por MET-EDS, os nanotubos naturais ativados com o metal incorporado foram tratados termicamente no forno de atmosfera redutora $\left(\mathrm{H}_{2} / \mathrm{Ar}\right)$ nas mesmas condições determinadas de colapso estrutural.

Uma vez conhecidos os parâmetros que envolvem a incorporação dos metais nos nanotubos ativados, foi realizado o mesmo processo de incorporação nas mesmas condições de volume, massa, tempo de contato, temperatura, concentração dos metais e pH final da solução, para a amostra sem ativar. A incorporação dos radionuclídeos simulados nos nanotubos sem ativar foi caraterizada pela técnica FRX-EDS.

O procedimento experimental esquemático do processo PIRNan é apresentado na FIG.20.

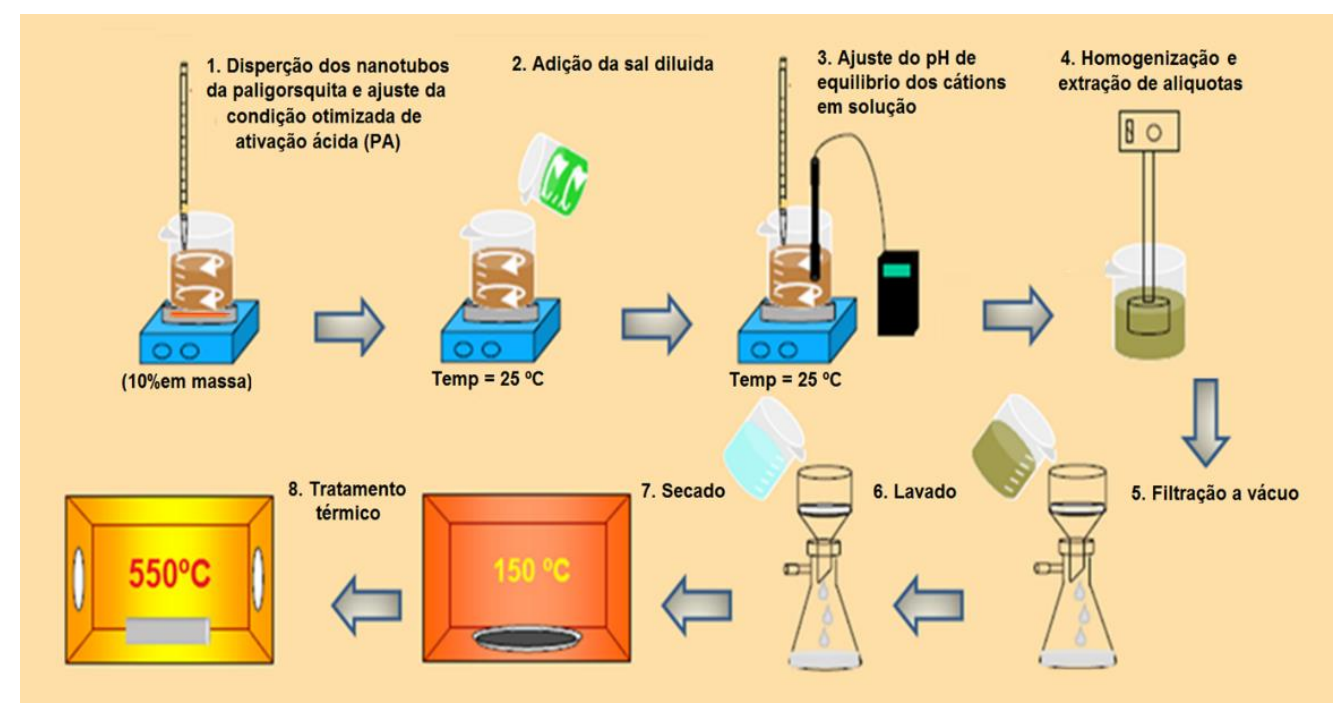

FIGURA 20 - Fluxograma do processo de incorporação de radionuclídeos nos nanotubos naturais ativados de paligorsquita (Autor). 


\section{RESUltAdOS E DISCUSSÃo}

\subsection{Caracterização da paligorsquita}

A caracterização da paligorsquita tem como objetivo adequar e estudar o material como recebido para poder realizar as etapas experimentais posteriores de ativação ácida, tratamento térmico, incorporação e imobilização dos cátions.

\subsubsection{Difração de raios X (DRX)}

O difratograma de raios $\mathrm{X}$ obtido a partir de uma amostra de paligorsquita como recebida $(P N)$ é apresentado na FIG.21.

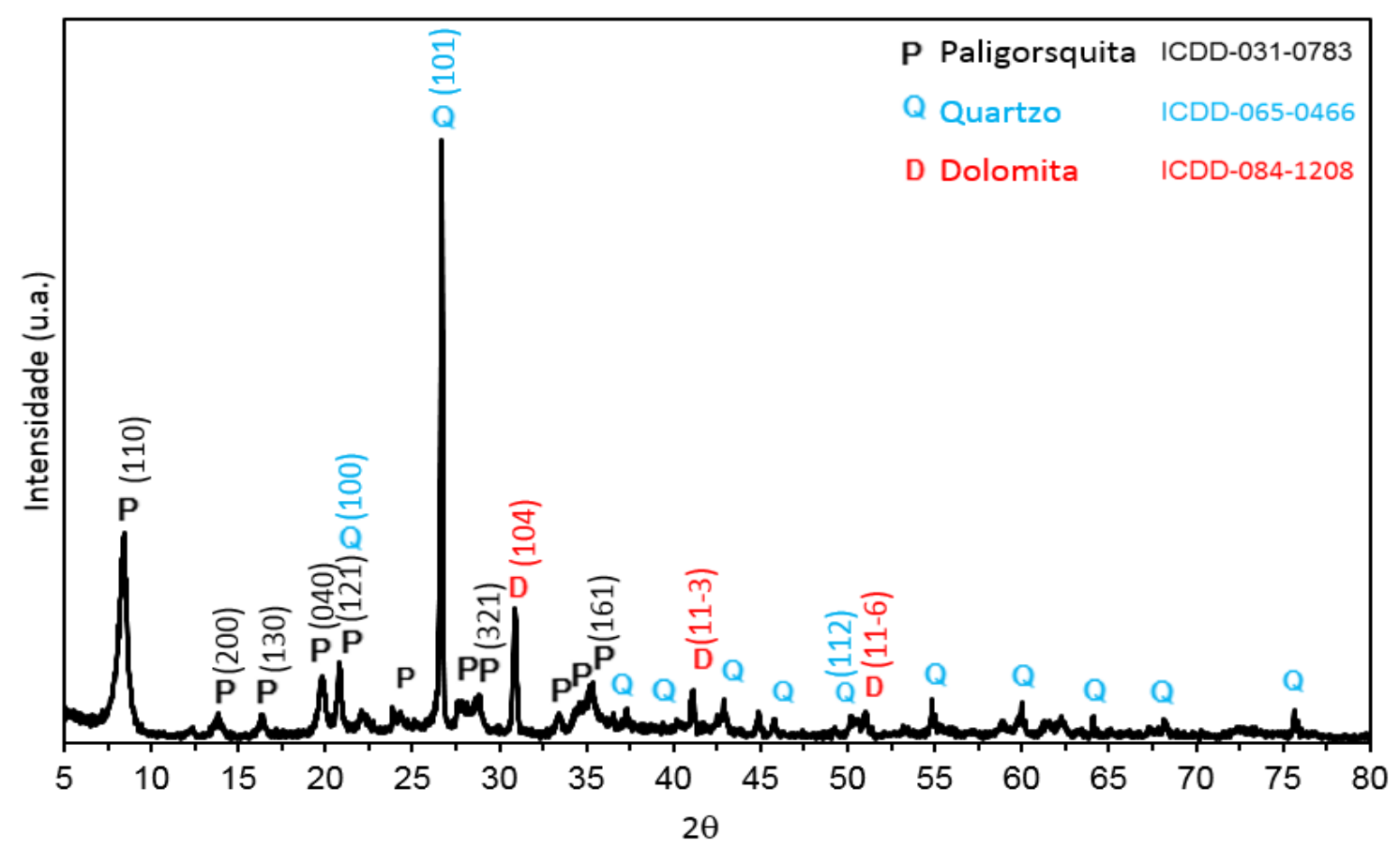

FIGURA 21 - Difratograma de Raios X da paligorsquita como recebida (PN).

$\mathrm{Na}$ FIG.21 observam-se as principais reflexões referentes à paligorsquita, quartzo e dolomita, as quais foram identificadas com auxílio das fichas cristalográficas ICDD de $\mathrm{n}^{\circ}$ 031-0783, 065-0466 e 084-1208, respectivamente, como listadas nas TAB.10, 11 e 12. 
TABELA 10 - Principais reflexões da ficha ICDD - 031 - 0783 usada para identificar as reflexões da paligorsquita na amostra de paligorsquita como recebida (CHRIST, HATHAWAY, et al., 1969).

\begin{tabular}{cccc}
\hline \multicolumn{2}{c}{ ICDD-031-0783 } & \multicolumn{2}{c}{$\boldsymbol{P N}$} \\
\hline Principais Reflexões & $\boldsymbol{d}(\mathbf{n m})$ & $\mathbf{2 \theta}$ & $\boldsymbol{d}(\mathbf{n m})$ \\
\hline $\mathbf{1 1 0}$ & 1,040 & 8,46 & 1,042 \\
$\mathbf{2 0 0}$ & 0,635 & 13,86 & 0,640 \\
$\mathbf{1 3 0}$ & 0,540 & 16,40 & 0,539 \\
$\mathbf{0 4 0}$ & 0,447 & 19,86 & 0,447 \\
$\mathbf{1 2 1}^{*}$ & 0,426 & 20,82 & $0,424^{1}$ \\
$\mathbf{3 2 1}^{*}$ & 0,309 & 28,78 & $0,309^{1}$ \\
$\mathbf{1 6 1}^{\mathbf{1 6 1}}$ & 0,253 & 35,31 & 0,253 \\
\hline
\end{tabular}

TABELA 11 - Principais reflexões da ficha ICDD - 065 - 0466 usada para identificar as reflexões do quartzo na amostra de paligorsquita como recebida (LAGER, JORGENSEN e ROTELLA, 1982).

\begin{tabular}{cccc}
\hline \multicolumn{2}{c}{ ICDD-065-0466 } & \multicolumn{2}{c}{ PN } \\
\hline Principais Reflexões & $\boldsymbol{d}(\mathbf{n m})$ & $\mathbf{2 \theta}$ & $\boldsymbol{d}(\mathbf{n m})$ \\
\hline $\mathbf{1 0 0}$ & 0,425 & 20,86 & 0,425 \\
101 & 0,334 & 26,65 & 0,334 \\
112 & 0,181 & 50,09 & 0,181 \\
\hline
\end{tabular}

TABELA 12 - Principais reflexões da ficha ICDD - 084 - 1208 usada para identificar as reflexões da dolomita na amostra de paligorsquita como recebida (MISER, SWINNEA e STEINFINK, 1987).

\begin{tabular}{cccc}
\hline \multicolumn{2}{c}{ ICDD-084-1208 } & \multicolumn{2}{c}{$\boldsymbol{P N}$} \\
\hline Principais Reflexões & $\boldsymbol{d}(\mathbf{n m})$ & $\mathbf{2 \theta}$ & $\boldsymbol{d}(\mathbf{n m})$ \\
\hline $\mathbf{1 0 4}$ & 0,288 & 30,90 & 0,289 \\
$\mathbf{1 1 - 3}$ & 0,219 & 41,07 & 0,219 \\
$\mathbf{1 1 - 6}$ & 0,178 & 51,04 & 0,178 \\
\hline
\end{tabular}


As reflexões obtidas na difração de raios $X$ ajustam-se com a paligorsquita de estrutura ortorrômbica da ficha ICDD-031-0783, de fórmula teórica: $\mathrm{Mg}_{5}(\mathrm{Si}, \mathrm{Al})_{8} \mathrm{O}_{20}(\mathrm{OH})_{2}\left(\mathrm{OH}_{2}\right)_{4} \cdot 4\left(\mathrm{H}_{2} \mathrm{O}\right)$.

Segundo a classificação proposta por SUÁREZ, GARCÍA-ROMERO, et al. (2007), a paligorsquita estudada neste trabalho é do tipo II correspondendo com a "paligorsquita comum" a qual possui a reflexão $d_{200}=0,640 \mathrm{~nm}$ entre os valores especificados $\left(0,635<\mathrm{d}_{200}<0,646\right)$ característicos da paligorsquita com substituições isomórficas dos cátions de alumínio na camada octaédrica, apresentando caráter dioctaédrico.

\subsubsection{Fluorescência de raios $X$ com dispersão de energia (FRX-EDS)}

A paligorsquita como recebida foi analisada por fluorescência de raios $X$ com dispersão de energia (FRX-EDS).

Os resultados da composição química apresentados na TAB.13 (\% óxidos), diferem da paligorsquita de formula teórica $\mathrm{Mg}_{5}(\mathrm{Si}, \mathrm{Al})_{8} \mathrm{O}_{20}(\mathrm{OH})_{2}\left(\mathrm{OH}_{2}\right)_{4} .4\left(\mathrm{H}_{2} \mathrm{O}\right)$ identificada por $D R X$, estes resultados apresentam a possível existência de substituição isomórfica de diferentes cátions como Al e Fe, a possível existência de outros minerais ou a presencia de cátions de compensação da rede estrutural como o $\mathrm{Fe}, \mathrm{Ti}, \mathrm{K}$ e $\mathrm{Mn}$, que são metais que normalmente estão presentes nestes argilominerais.

TABELA 13 - Resultados em óxidos da análise por Fluorescência de Raios-X por dispersão de energia (EDS) da paligorsquita (PN).

\begin{tabular}{cccccccccc}
\hline \multicolumn{10}{c}{ Composição (\% em massa) } \\
\hline AMOSTRA & $\mathrm{SiO}_{2}$ & $\mathrm{Al}_{2} \mathrm{O}_{3}$ & $\mathrm{MgO}$ & $\mathrm{Fe}_{2} \mathrm{O}_{3}$ & $\mathrm{CaO}$ & $\mathrm{K}_{2} \mathrm{O}$ & $\mathrm{TiO}_{2}$ & $\mathrm{MnO}$ & P.F. \\
\hline $\boldsymbol{P N}$ & 42,0 & 10,1 & 12,4 & 3,9 & 6,3 & 1,0 & 0,6 & 0,3 & 23,4 \\
\hline
\end{tabular}

A existência de $\mathrm{CaO}(6,3 \%)$ e do alto teor de $\mathrm{MgO}(12,4 \%)$ pode se dever a presenças de minerais, como dolomita. Em adição, possui quase $25 \%$ de perda ao fogo (PF), valor pouco comum nestes argilominerais que normalmente apresentam valores compreendidos entre 8-18\%. Quando comparada com as análises químicas de paligorsquita extraída da mesma região referida na literatura (XAVIER, SILVA- 
FILHO), esta apresenta diferenças na composição, o que pode ser atribuído a presença de outros minerais como explicado anteriormente.

Para calcular a fórmula química de este argilomineral é necessário realizar o tratamento de purificação.

\subsubsection{Espectroscopia de absorção na região do infravermelho (FT-IR)}

Os espectros obtidos no infravermelho para os argilominerais são importantes por aportar informação em relação à sua composição, estrutura, ligações e propriedades químicas. $O$ espectro de infravermelho da paligorsquita encontra-se na FIG.22.

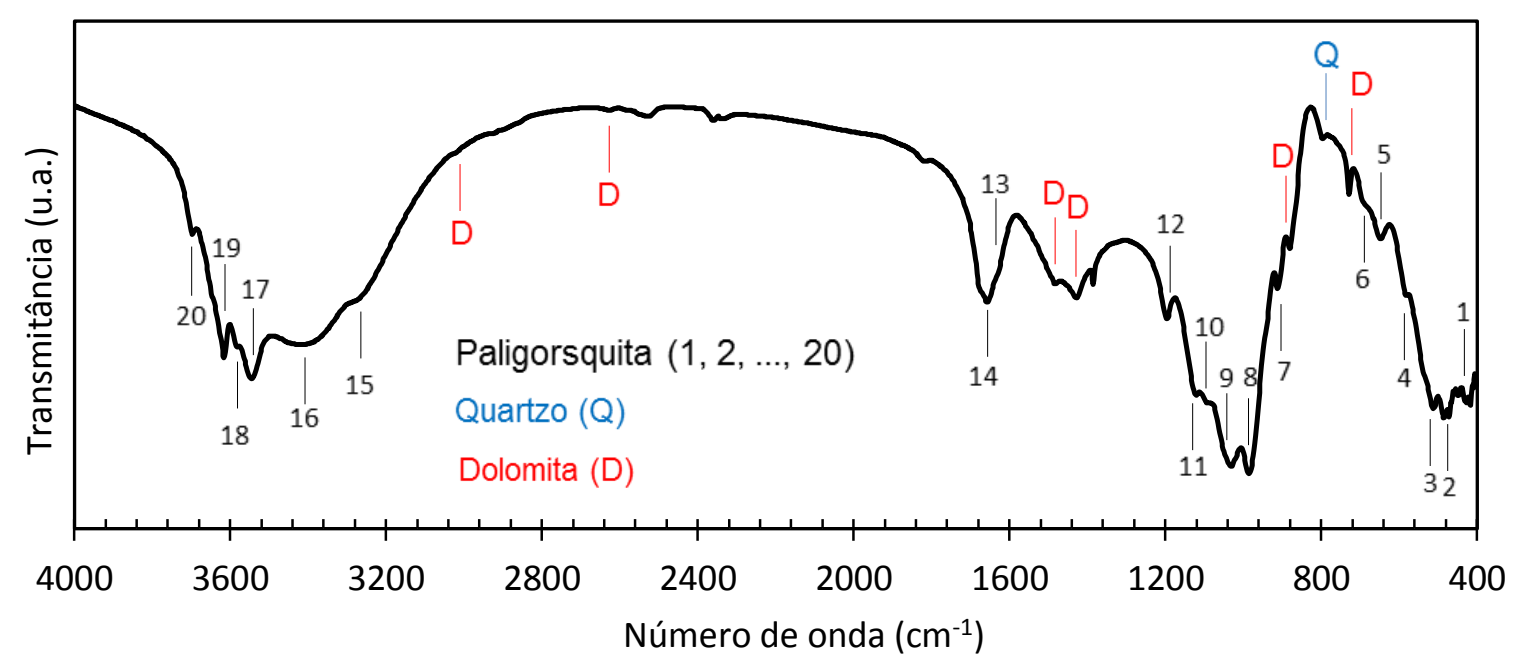

FIGURA 22 - Espectro infravermelho da paligorsquita como recebida.

As bandas da paligorsquita encontradas neste trabalho estão representadas na TAB.14. Estas bandas coincidem com os valores reportados por YAN, LIU, et al. (2012) para a paligorsquita, listados na TAB.8 (item 2.4.6).

As bandas características da paligorsquita ocorrem a 647 e $1195 \mathrm{~cm}^{-1}$, identificadas na FIG.22 como 5 e 12, respectivamente. A banda a $647 \mathrm{~cm}^{-1}$, é atribuída à vibração de estiramento do $\mathrm{H}_{2} \mathrm{O}-\mathrm{Mg}-\mathrm{H}_{2} \mathrm{O}$, e possivelmente possui uma relação com a peculiar estrutura em nanotubos da paligorsquita. A banda que ocorre em $1195 \mathrm{~cm}^{-1}$ é atribuída à vibração de estiramento assimétrico do oxigênio no grupo $\mathrm{Si}-\mathrm{O}_{1}-\mathrm{Si}$ das folhas tetraédricas e que é característica dos minerais com tetraedros invertidos (YAN, LIU, et al., 2012). 
A banda a $3697 \mathrm{~cm}^{-1}$, atribuída à vibração de estiramento do $\mathrm{Mg}_{3}-\mathrm{OH}$, foi identificada por outros autores a $3680 \mathrm{~cm}^{-1}$ (YAN, LIU, et al., 2012) e $3700 \mathrm{~cm}^{-1}$ (MIDDEA, FERNANDES, et al., 2013). No entanto alguns autores a atribuíram à vibração de estiramento assimétrico do grupo $\mathrm{Si}-\mathrm{OH}$ localizado na superfície externa das fibras (HUO e YANG, 2012).

As bandas identificadas a $3020,2626,1483,1428,870$ e $730 \mathrm{~cm}^{-1}$ foram atribuídas à presença de dolomita (JI, GE, et al., 2009).

A banda em $798 \mathrm{~cm}^{-1}$ é atribuída à vibração de estiramento simétrica do quartzo livre $\left(\mathrm{Si}_{-} \mathrm{O}_{2}-\mathrm{Si}\right)$ presente na amostra (SUÁREZ-BARROS e GARCÍAROMERO, 2006).

TABELA 14 - Identificação das bandas de adsorção e dos modos de vibração característicos da paligorsquita como recebida (PN)

Paligorsquita como recebida $(P N)$

\begin{tabular}{|c|c|c|c|c|c|}
\hline fld. & $\begin{array}{l}\text { Banda } \\
\left(\mathrm{cm}^{-1}\right)\end{array}$ & Modo de vibração & fld. & $\begin{array}{l}\text { Banda } \\
\left(\mathrm{cm}^{-1}\right)\end{array}$ & Modo de vibração \\
\hline 1 & 433 & ${ }^{\mathrm{a}} \mathrm{V}_{\mathrm{s}}, \mathrm{MgO}_{6}$ octaédrico & 11 & 1120 & ${ }^{d} \mathrm{~V}_{\mathrm{as}}, \mathrm{Si}-\mathrm{O}_{2}-\mathrm{Si}$ \\
\hline 2 & 478 & ${ }^{\mathrm{b}} \delta, \mathrm{O}-\mathrm{Si}-\mathrm{O}$ & 12 & 1196 & ${ }^{d} V_{a s}, S i-O_{1}-S i$ \\
\hline 3 & 510 & $\delta, \mathrm{Si}-\mathrm{O}-\mathrm{Si}$ & 13 & 1630 & $\delta, \mathrm{H}_{2} \mathrm{O}$ \\
\hline 4 & 580 & $\mathrm{~V}_{\mathrm{s}}, \mathrm{AlO}_{6}$ octaédrico & 14 & 1653 & $\delta,{ }^{e} \mathrm{OH}_{2}$ \\
\hline 5 & 647 & $\mathrm{~V}_{\mathrm{s}},{ }^{\mathrm{c}} \mathrm{H}_{2} \mathrm{O}-\mathrm{Mg}-\mathrm{H}_{2} \mathrm{O}$ & 15 & 3260 & $\begin{array}{c}\text { Vs, } \mathrm{H}_{2} \mathrm{O} \text { ligada ao } \\
\text { oxigênio em Si-O-Al }\end{array}$ \\
\hline 6 & 680 & $\begin{array}{l}\mathrm{V}_{\mathrm{s}}, \mathrm{Si}-\mathrm{O}-\mathrm{Mg} / \\
\mathrm{V}_{\mathrm{s}}, \mathrm{Si}-\mathrm{O}-\mathrm{Al}\end{array}$ & 16 & 3411 & $\mathrm{~V}_{\mathrm{s}}, \mathrm{H}_{2} \mathrm{O}$ \\
\hline 7 & 910 & $\delta, \mathrm{Al}-\mathrm{OH}-\mathrm{Al}$ & 17 & 3545 & $\mathrm{~V}_{\mathrm{s}}, \mathrm{OH}_{2}$ \\
\hline 8 & 987 & ${ }^{d} V_{a s}, S i-O_{n b}-M g(V I)$ & 18 & 3582 & $\mathrm{~V}_{\mathrm{s}}, \mathrm{Al}-\mathrm{OH}-\mathrm{Fe}^{3}$ \\
\hline 9 & 1033 & ${ }^{d} \mathrm{~V}_{\text {as }}, \mathrm{Si}-\mathrm{O}_{3}-\mathrm{Si}$ & 19 & 3615 & $\mathrm{~V}_{\mathrm{s}}, \mathrm{Al}-\mathrm{OH}-\mathrm{Al}$ \\
\hline 10 & 1093 & ${ }^{d} V_{a s}, \mathrm{SiO}_{4}$ & 20 & 3697 & $\mathrm{~V}_{\mathrm{s}}, \mathrm{Mg}_{3}-\mathrm{OH}$ \\
\hline
\end{tabular}

a $\bigvee_{s}$ vibração de estiramento simétrica, ${ }^{b} \delta$, vibração da deformação ${ }^{c} \mathrm{H}_{2} \mathrm{O}$ Zeolitica e $\mathrm{H}_{2} \mathrm{O}$ absorvida superficial (fissisorvida), ${ }^{d} \mathrm{~V}_{\mathrm{as}}$, vibração de estiramento assimétrica, ${ }^{\mathrm{e}} \mathrm{OH}_{2}$, água ligada e ${ }^{\mathrm{d}} \mathrm{ld}$, Identificação 


\subsubsection{Distribuição granulométrica}

A curva de distribuição de tamanho das partículas é bastante estreita ou seja $100 \%$ das partículas analisadas apresentam um diâmetro médio superior a $250 \mathrm{~nm}$ e inferior a $260 \mathrm{~nm}$, como pode se observar na análise de distribuição granulométrica da FIG.23 apresentando um tamanho médio de partícula $\left(\mathrm{d}_{50}\right)=$ 256,8 nm.

Estes argilominerais quando bem desagregados apresentam tamanho de partículas bastante finos, da ordem de nanômetros (GANTENBEIN, SCHOELKOPF, et al., 2011; STOYLOV e PETKANCHIN, 1972). Provavelmente os resultados aqui apresentados referem-se a alguns aglomerados.

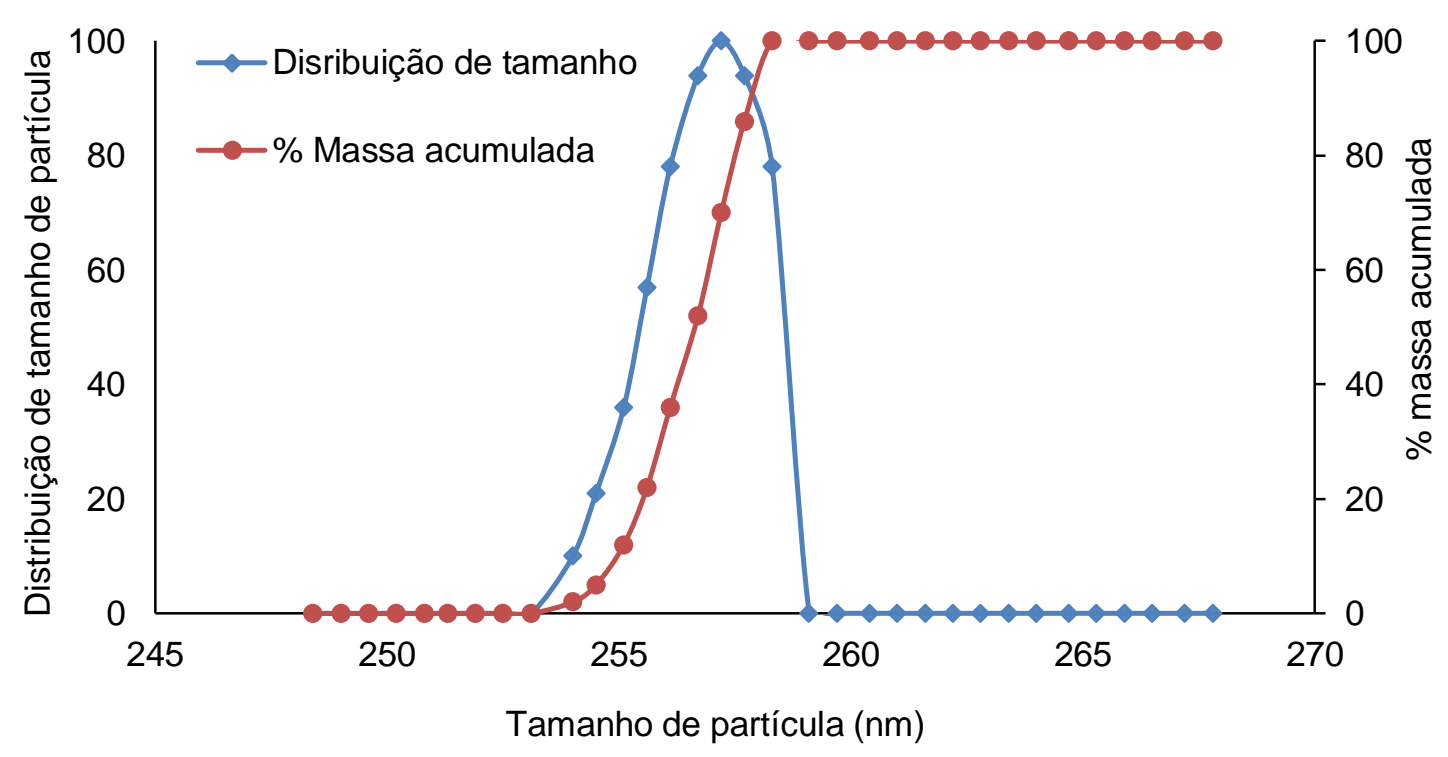

FIGURA 23 - Curva de distribuição de tamanho de partículas a partir de uma amostra de paligorsquita como recebida (PN).

\subsection{5 Área superficial específica (BET), área e volume dos microporos e parâmetros físicos relacionados}

A FIG.24 apresenta as curvas das isotermas de adsorção e dessorção de $\mathrm{N}_{2}$ da paligorsquita como recebida (PN) obtidas a partir das análises BET, onde observa-se que ocorre uma histerese entre as curvas de adsorção e dessorção, indicando a presencia de porosidade interna na estrutura. 
Segundo a classificação da IUPAC (IUPAC, 2014) a histerese observada entre as curvas de adsorção e dessorção para valores de $\left(P / P_{0}\right)$ superiores a 0,5 indicam a presença de mesoporos (poros entre 2 e $50 \mathrm{~nm}$ ), correspondendo à isoterma de adsorção-dessorção tipo IV.

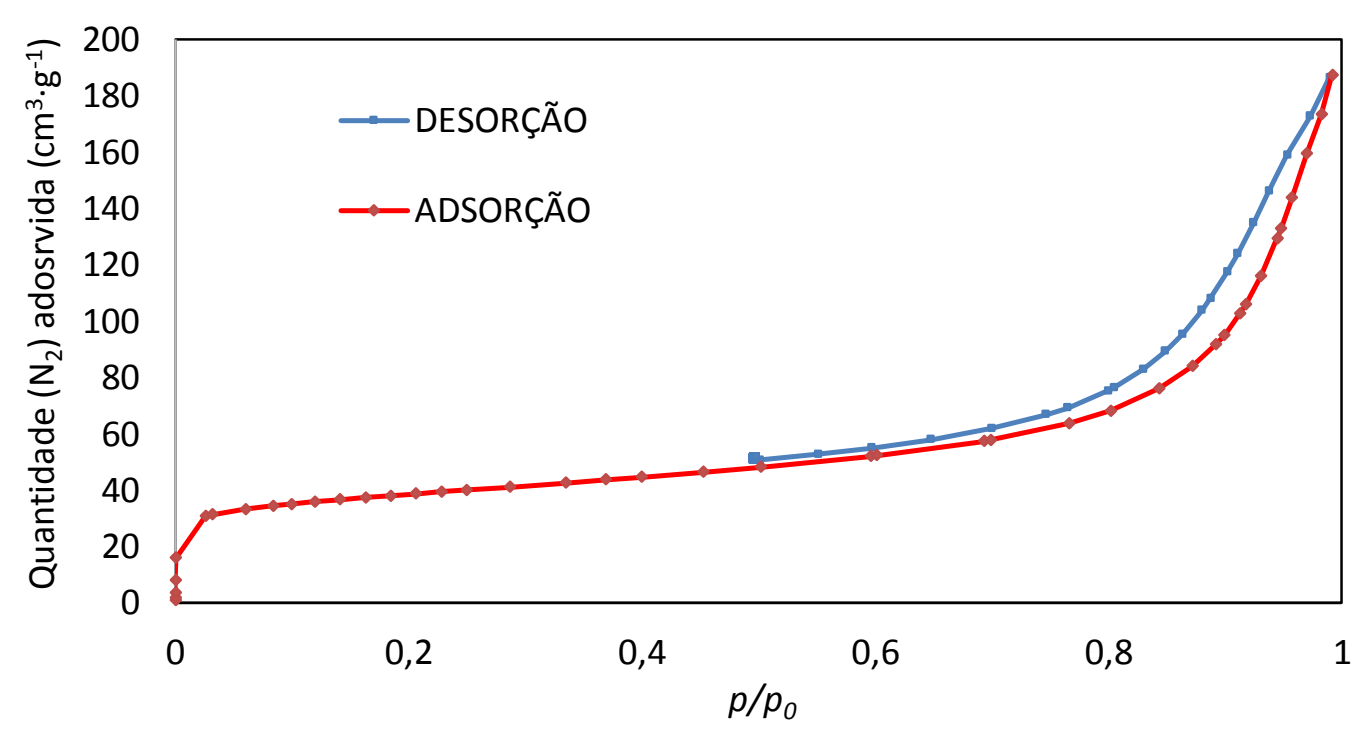

FIGURA 24 - Isoterma de adsorção-dessorção de $\mathrm{N}_{2}$ da paligorsquita como recebida $(\mathrm{PN})$.

Os valores determinados para a área superficial específica, volume, diâmetro médios de poro, área e volume dos microporos da paligorsquita estão listados na $T A B .15$.

TABELA 15 - Área superficial específica, área e volume dos microporos e parâmetros físicos relacionados da paligorsquita como recebida (PN).

\begin{tabular}{cccccccc}
\hline AMOSTRA & $\begin{array}{c}\boldsymbol{S}_{\mathrm{BET}} \\
\left(\mathrm{m}^{2} \cdot \mathrm{g}^{-1}\right)\end{array}$ & $\begin{array}{c}\boldsymbol{S}_{\text {ext }} \\
\left(\mathrm{m}^{2} \cdot \mathrm{g}^{-1}\right)\end{array}$ & $\begin{array}{c}\boldsymbol{S}_{\text {micro }} \\
\left(\mathrm{m}^{2} \cdot \mathrm{g}^{-1}\right)\end{array}$ & $\begin{array}{c}\boldsymbol{V}_{\text {TOTAL }} \\
\left(\mathrm{cm}^{3} \cdot \mathrm{g}^{-1}\right)\end{array}$ & $\begin{array}{c}\boldsymbol{V}_{\text {micro }} \\
\left(\mathrm{cm}^{3} \cdot \mathrm{g}^{-1}\right)\end{array}$ & $\begin{array}{c}\boldsymbol{V}_{\text {meso }} \\
\left(\mathrm{cm}^{3} \cdot \mathrm{g}^{-1}\right)\end{array}$ & $\begin{array}{c}\boldsymbol{d}_{\text {médio }} \\
(\mathrm{nm})\end{array}$ \\
\hline $\boldsymbol{P N}$ & 137,7 & 83,33 & 54,37 & 0,2799 & 0,0234 & 0,2565 & 8,3 \\
\hline
\end{tabular}

O volume e a área de microporo da paligorsquita como recebida $(P M)$ avaliados neste trabalho apresentam valores bem maiores aos apresentados por outros autores, $V_{\text {micro }}=0,018 \mathrm{~cm}^{3} \cdot \mathrm{g}^{-1}$ (BOUDRICHE, CALVET, et al., 2012), Smicro $=12,7 \mathrm{~m}^{2} \cdot \mathrm{g}^{-1}$ e $\mathrm{V}_{\text {micro }}=0,005 \mathrm{~cm}^{3} \cdot \mathrm{g}^{-1}$ (ZHANG, WANG, et al., 2010) e $\mathrm{S}_{\text {micro }}=28$ $\mathrm{m}^{2} \cdot \mathrm{g}^{-1}$ e $\mathrm{V}_{\text {micro }}=0,012 \mathrm{~cm}^{3} \cdot \mathrm{g}^{-1}$ (LIU, WANG e WANG, 2012). 


\subsubsection{Microscopia eletrônica de varredura (MEV)}

A FIG.25 mostra as micrografias obtidas por MEV da amostra de paligorsquita como recebida $(P N)$, a qual exibe uma morfologia de aglomerados de $5-15 \mu \mathrm{m}$ de diâmetro, constituídos por pequenos bastonetes aciculares. Nestas imagens aleatórias pode-se observar que o tamanho médio destes bastonetes varia de 0,2 a $2 \mu \mathrm{m}$. Estes resultados estão de acordo como os resultados observados por XAVIER, SILVA-FILHO, et al. (2012).
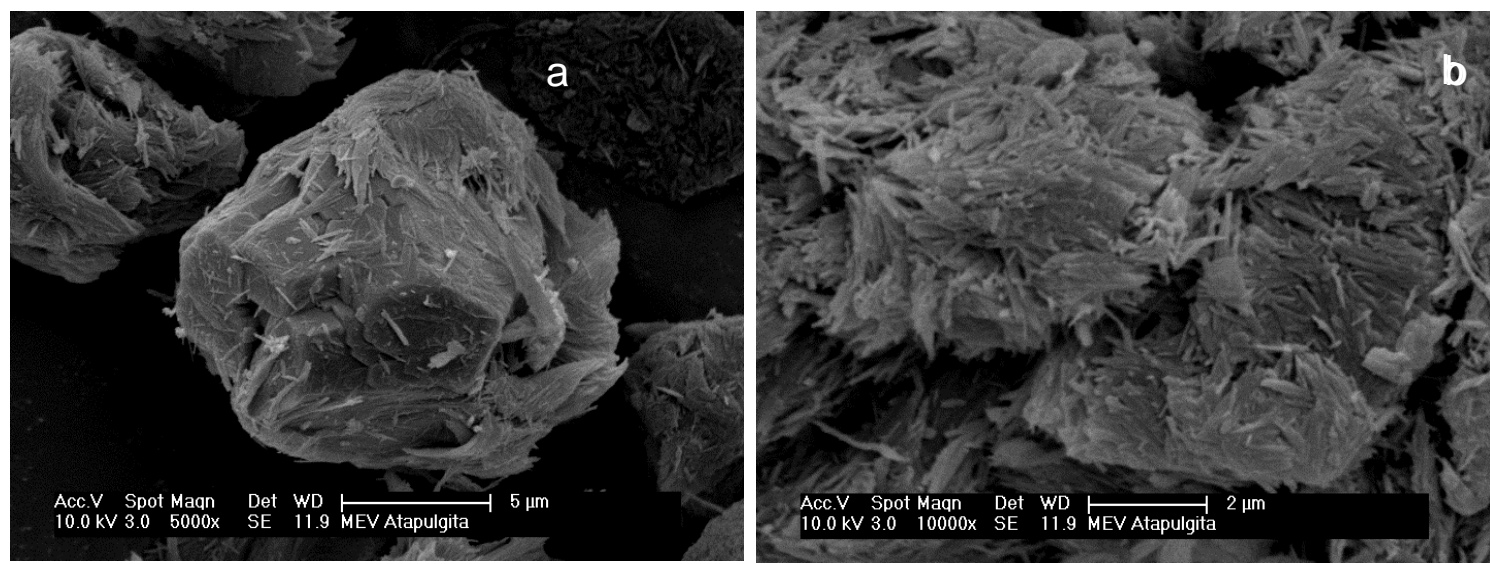

FIGURA 25 - Micrografias da paligorsquita como recebida (PN) obtidas por microscopia eletrônica de varredura (MEV).

\subsubsection{Capacidade de troca catiônica (CTC)}

A análise da capacidade de troca catiônica da paligorsquita indicou que esta apresenta um valor de troca de $19 \mathrm{meq} / 100 \mathrm{~g}$, resultado que se encontra dentro do valor de CTC esperado quando comparado com os dados da literatura que variam entre 20 e $30 \mathrm{meq} / 100 \mathrm{~g}$.

\subsubsection{Análise térmica diferencial e termogravimétrica (ATD/TG)}

As curvas das análises térmicas diferencial e gravimétricas (ATD e ATG) da paligorsquita estão representadas na FIG.26. A análise Termogravimétrico, ATG, 
aponta vários eventos de perda de massa com o aumento da temperatura, até $22,2 \%$ em relação a massa inicial, com valores de 7,4\%,2,3\%, 5\% e 7,3\% massa.

O comportamento térmico deste argilomineral representado na FIG.26, indica uma série de processos de desidratação, deshidroxilação e decomposição térmica (CHENG, YANG e FROST, 2011; LOPEZ-GALINDO, VISERAS e CEREZO, 2007): o primeiro $\left(20-154{ }^{\circ} \mathrm{C}\right)$ é relacionado com a perda de água superficial e parte da água zeolitica, dando lugar à perda de massa de 7,4\%; 0 segundo (154-279 $\left.{ }^{\circ} \mathrm{C}\right)$ é relacionado à desidratação térmica completa da água zeolitica presente nos canais estruturais, atribuída à perda de massa do 2,3\% sendo um fenômeno totalmente reversível (CHENG, YANG e FROST, 2011); o terceiro é atribuído a soma de dois processos, o primeiro é à perda da água estrutural ligado aos íons de magnésio e o segundo é a deshidroxilação dos íons hidroxilos ligados no interior da estrutura, onde a remoção das moléculas de água nesta faixa de temperaturas (279-537 $\left.{ }^{\circ} \mathrm{C}\right)$ é acompanhada por uma destruição parcial da estrutura cristalina da paligorsquita, sendo este um fenômeno irreversível (BOUDRICHE, CALVET, et al., 2012) este evento corresponde a perda de massa do $5 \%$; e finalmente, o quarto (537-777 ํㅡ) é possivelmente devido à decomposição térmica da dolomita, tendo lugar a perda de massa de $7,3 \%$.

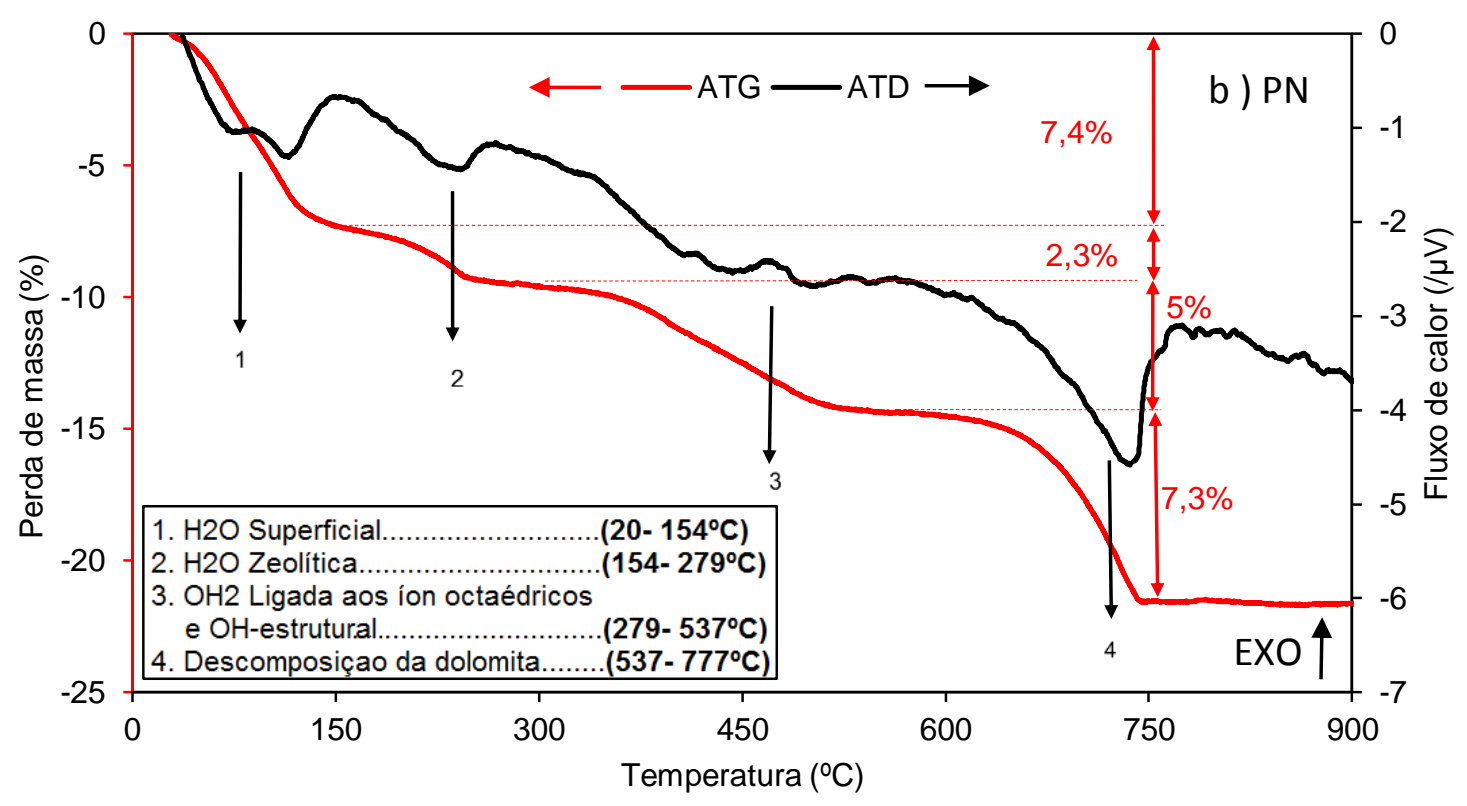

FIGURA 26 - Análises Termogravimétrico (ATG) e Termodiferencial (ATD) da paligorsquita como recebida. 
Este último evento endotérmico foi atribuído à decomposição da dolomita, a qual foi identificada anteriormente pelas técnicas de caracterização (DRX e FT-IR).

\subsection{Purificação}

Como identificado anteriormente por meio das técnicas de caracterização $D R X$ e FT-IR juntamente com as análises de $A T D / T G$, a dolomita $\left(\mathrm{MgCa}\left(\mathrm{CO}_{3}\right)_{2}\right)$ encontra se presente como impureza mineral na amostra de paligorsquita como recebida $(P N)$. Devido ao seu excessivo conteúdo de magnésio e de cálcio, e facilidade de dissolução em meio ácido, a dolomita poderá interferir nos resultados dos estudos posteriores de ativação ácida superficial da estrutura dos nanotubos.

A remoção da dolomita foi confirmada pelas análises estruturais ( $D R X, F T$ $I R)$, químicas (FRX-EDS) e térmicas ( $A T D / T G)$, como apresentados nas $T A B .17 \mathrm{e}$ 18 e FIG.27 e 30, nas quais apresentam-se os valores e figuras correspondentes a paligorsquita como recebida $(P N)$ para fins comparativos.

O difratograma de difração de raios $X$ obtido após o processo de purificação da paligorsquita identificada como $(P P)$, é apresentado na FIG.27, nele pode se observar quando comparado ao difratograma da paligorsquita como recebida $(P N)$, a afetividade do tratamento de purificação, visando a remoção da dolomita.

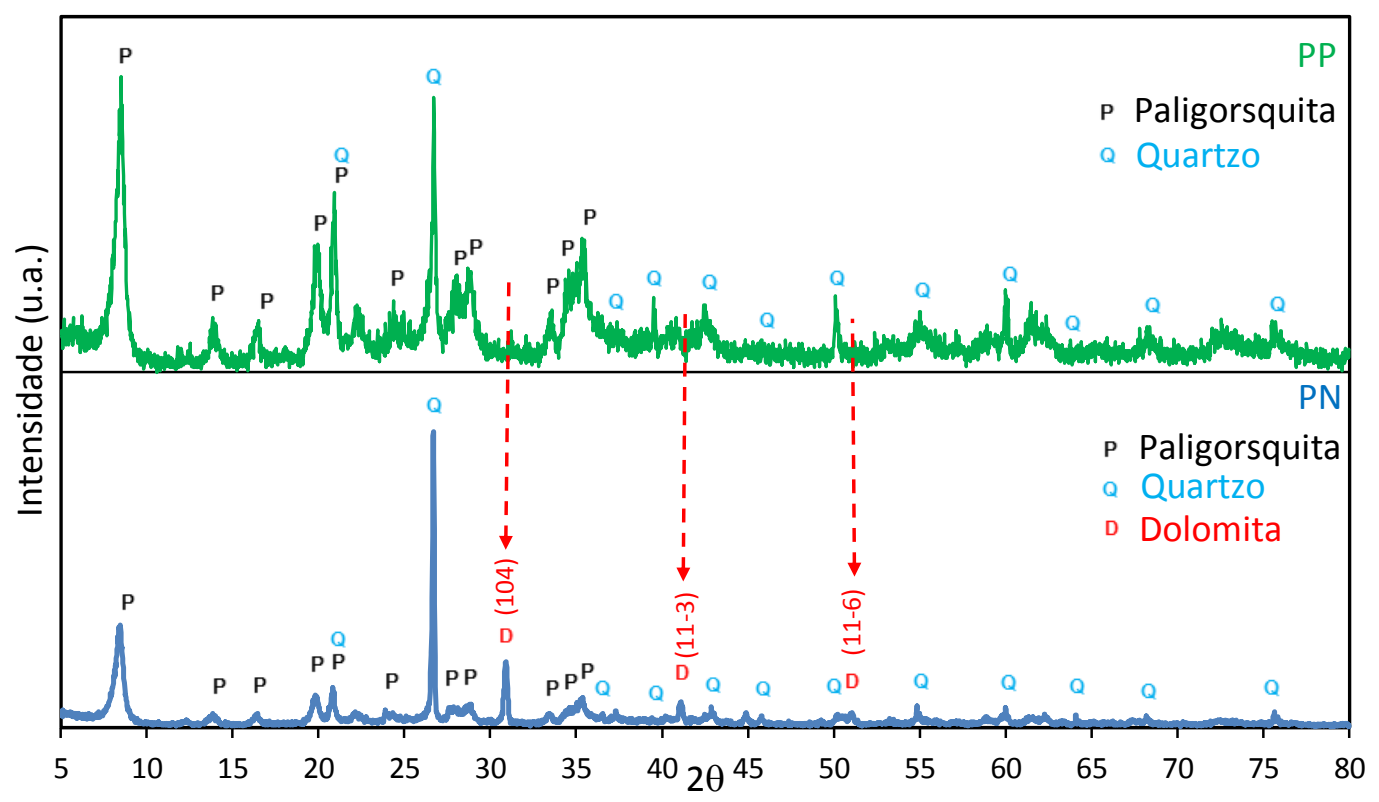

FIGURA 27 - Difratogramas da paligorsquita como recebida (PN) e purificada $(\mathrm{PP})$. 
A TAB.16 ilustra que o processo de purificação foi efetivo na remoção apenas da dolomita e não causou modificações estruturais no argilomineral, analisando as principais reflexões comparadas com a $P N$.

TABELA 16 - Principais reflexões identificadas na ficha ICDD -031-0788 e comparação das reflexões da paligorsquita como recebida $(\mathrm{PN})$ com as reflexões da paligorsquita purificada (PP).

\begin{tabular}{ccccccc}
\hline Principais Reflexões & \multicolumn{2}{c}{$(\mathbf{1 1 0})$} & \multicolumn{2}{c}{$\mathbf{( 2 2 0 )}$} & \multicolumn{2}{c}{$\mathbf{( 0 4 0 )}$} \\
\hline AMOSTRA & $2 \theta$ & $\mathrm{d}(\mathrm{nm})$ & $2 \theta$ & $\mathrm{d}(\mathrm{nm})$ & $2 \theta$ & $\mathrm{d}(\mathrm{nm})$ \\
\hline ICDD-031-0783 & $8,50^{\circ}$ & 1,040 & $13,92^{\circ}$ & 0,635 & $19,85^{\circ}$ & 0,447 \\
$\boldsymbol{P N}$ & $8,46^{\circ}$ & 1,042 & $13,82^{\circ}$ & 0,640 & $19,84^{\circ}$ & 0,447 \\
$\boldsymbol{P P}$ & $8,48^{\circ}$ & 1,041 & $13,82^{\circ}$ & 0,640 & $19,83^{\circ}$ & 0,447 \\
\hline
\end{tabular}

Na TAB.17 apresentam-se os resultados da análise química da paligorsquita como recebida $(P N)$ e após o processo de purificação $(P P)$.

A percentagem de dolomita $\left(\mathrm{MgCa}\left(\mathrm{CO}_{3}\right)_{2}\right.$ presente na amostra de paligorsquita como recebida $(P N)$ supondo que todo o $\mathrm{CaO}(\%)=6,3 \%$ pertence a dolomita é $20,73 \%$, do qual $4,6 \%$ corresponde à $\mathrm{MgO}$. Na análise química por $F R X$ $E D S$ da amostra purificada $(P P)$, o $\mathrm{CaO}$ não foi detectado e a concentração de $\mathrm{MgO}$ detectado foi 7,6\% valor praticamente similar ao teórico esperado de 7,8\%, obtido do balance estequiométrico da composição química em óxidos da amostra como recebida $(P M)$, o que indica a efetividade da purificação visando a remoção da dolomita. Este resultado está de acordo com as análises realizadas para amostras de paligorsquita da mesma região (XAVIER et al., 2012).

TABELA 17 - Resultados em óxidos da análise por FRX-EDS da paligorsquita como recebida (PN) e a purificada (PP).

\begin{tabular}{cccccccccc}
\hline \multicolumn{10}{c}{ Composição (\% em massa) } \\
\hline AMOSTRA & $\mathrm{SiO}_{2}$ & $\mathrm{Al}_{2} \mathrm{O}_{3}$ & $\mathbf{M g O}$ & $\mathrm{Fe}_{2} \mathrm{O}_{3}$ & $\mathrm{CaO}$ & $\mathrm{K}_{2} \mathrm{O}$ & $\mathrm{TiO}_{2}$ & $\mathrm{MnO}$ & $\boldsymbol{P . F .}$ \\
\hline $\boldsymbol{P P}$ & 56,2 & 13,4 & 7,6 & 6,1 & $\mathrm{ND}$ & 1,8 & 0,7 & 0,2 & 16,8 \\
$\boldsymbol{P N}$ & 42,0 & 10,1 & 12,4 & 3,9 & 6,3 & 1,0 & 0,6 & 0,3 & 23,4 \\
\hline
\end{tabular}


A fórmula estrutural ajustada proposta neste estudo, após a purificação e deduzida dos resultados da análise química para a amostra purificada $(P P)$, está representada na $E Q .17$. A formula química proposta para este trabalho segue o modelo proposto por BAILEY (1980) segundo a EQ.5 (item 3.3). A existencia de quartzo, o qual não foi removido no processo de purificação, como identificado na $D R X$ (FIG.27), foi calculado segundo o excesso de silicio na amostra $\left(\mathrm{Si}_{0,54} \mathrm{O}_{2}\right)$

$\left(\mathrm{Si}_{7,37} \mathrm{Al}_{0,46}\right)\left(\mathrm{Mg}_{1,59} \mathrm{Al}_{1,75} \mathrm{Fe}_{0,64}\right) \mathrm{O}_{20}(\mathrm{OH})_{2}\left(\mathrm{H}_{2} \mathrm{O}\right)_{4.4} \cdot 4\left(\mathrm{H}_{2} \mathrm{O}\right) .\left(\mathrm{K}_{0,04} \mathrm{Ti}_{0,02} \mathrm{Mn}_{0,01}\right)$

O espectro de infravermelho das duas condições, paligorsquita purificada $(P P)$ e como recebida $(P N)$, encontram-se representado na FIG.28. Comparandose os espectros, pode se observar que as bandas identificadas para a dolomita, na amostra como recebida ( $P M)$ identificadas a 3020, 2626, 1483, 1428, 870 e $730 \mathrm{~cm}^{-}$ 1, atribuídas à presença de dolomita (JI, GE, et al., 2009), não foram identificadas na amostra de paligorsquita purificada $(P P)$, confirmando a efetividade do processo na remoção da dolomita.

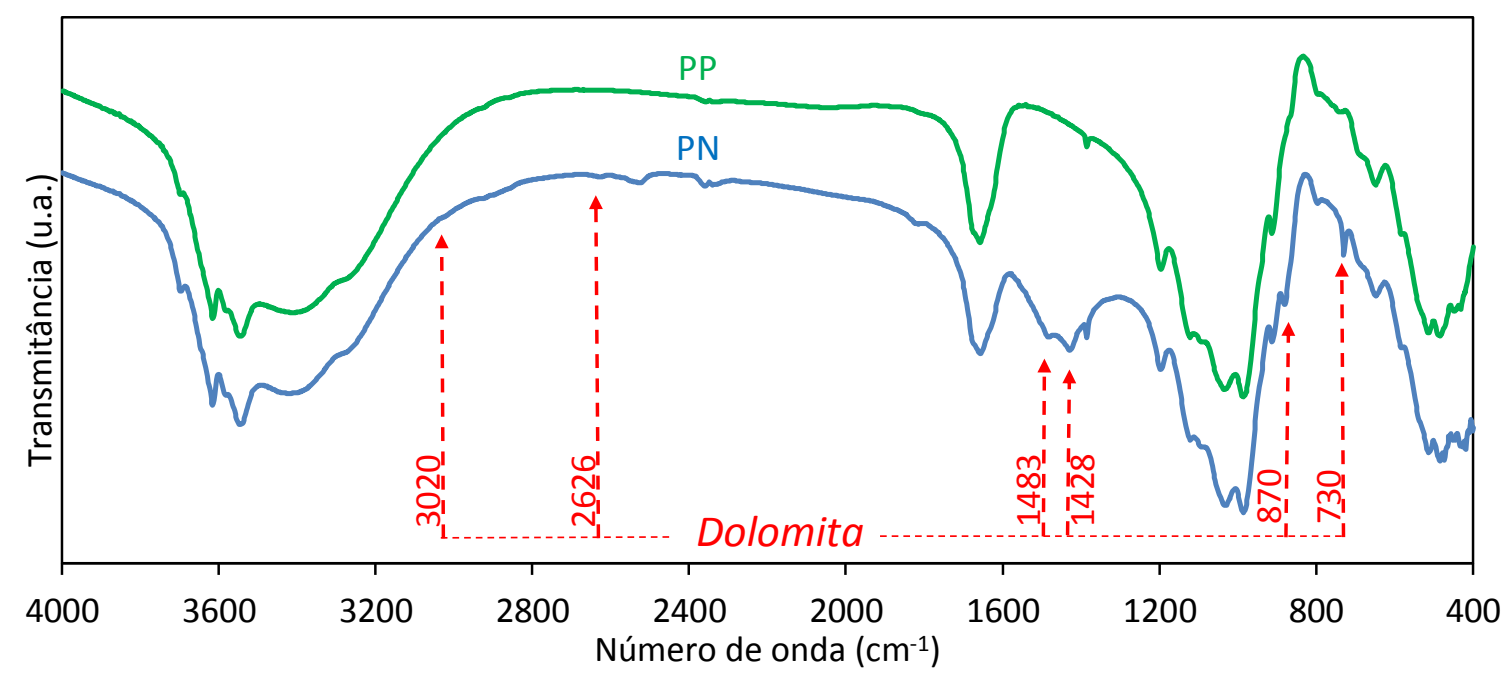

FIGURA 28 - Espectrogramas da paligorsquita como recebida (PN) e purificada $(\mathrm{PP})$.

As bandas características da paligorsquita encontrados neste trabalho, foram anteriormente representadas na $T A B .14$, com seus respectivos modos vibracionais de ligação. Nos espectros de infravermelho da FIG.28 podem se observar que as bandas características da paligorsquita natural $(P N)$ foram 
mantidas após o processo de purificação $(P P)$, confirmando que o tratamento de purificação não causou modificações na composição, estrutura, ligações ou propriedades químicas da paligorsquita, confirmando os resultados obtidos na $D R X$.

As curvas das análises térmico diferencial $(A T D)$ e termogravimétrica $(A T G)$ da paligorsquita purificada $(P P)$ e da paligorsquita como recebida $(P M)$, estão representadas na FIG.29.

Para a paligorsquita purificada (PP), representada na FIG.29.a pode-se apreciar a existência de uma série de eventos de desidratação e dehidroxilação, com o aumento da temperatura similares aos observados para a paligorsquita como recebida ( $P N$ ) representada na FIG.29b: As únicas diferenças observadas foram em relação à presença de uma maior quantidade de água adsorvida para a amostra $P P$, apresentando diferentes percentagens de perdas de massa e a não identificação do evento endotérmico entre $537-777^{\circ} \mathrm{C}$ atribuído à dolomita na FIG.29.b.

Após o processo de purificação, para a amostra $P P$, o último evento endotérmico, característico da dolomita, não foi identificado nestes resultados, o que indica que o processo de purificação visando a remoção da dolomita foi efetivo.

As termoanálises da paligorsquita purificada estão em harmonia com as análises realizadas pelas outras técnicas de caracterização anteriormente apresentadas e discutidas.

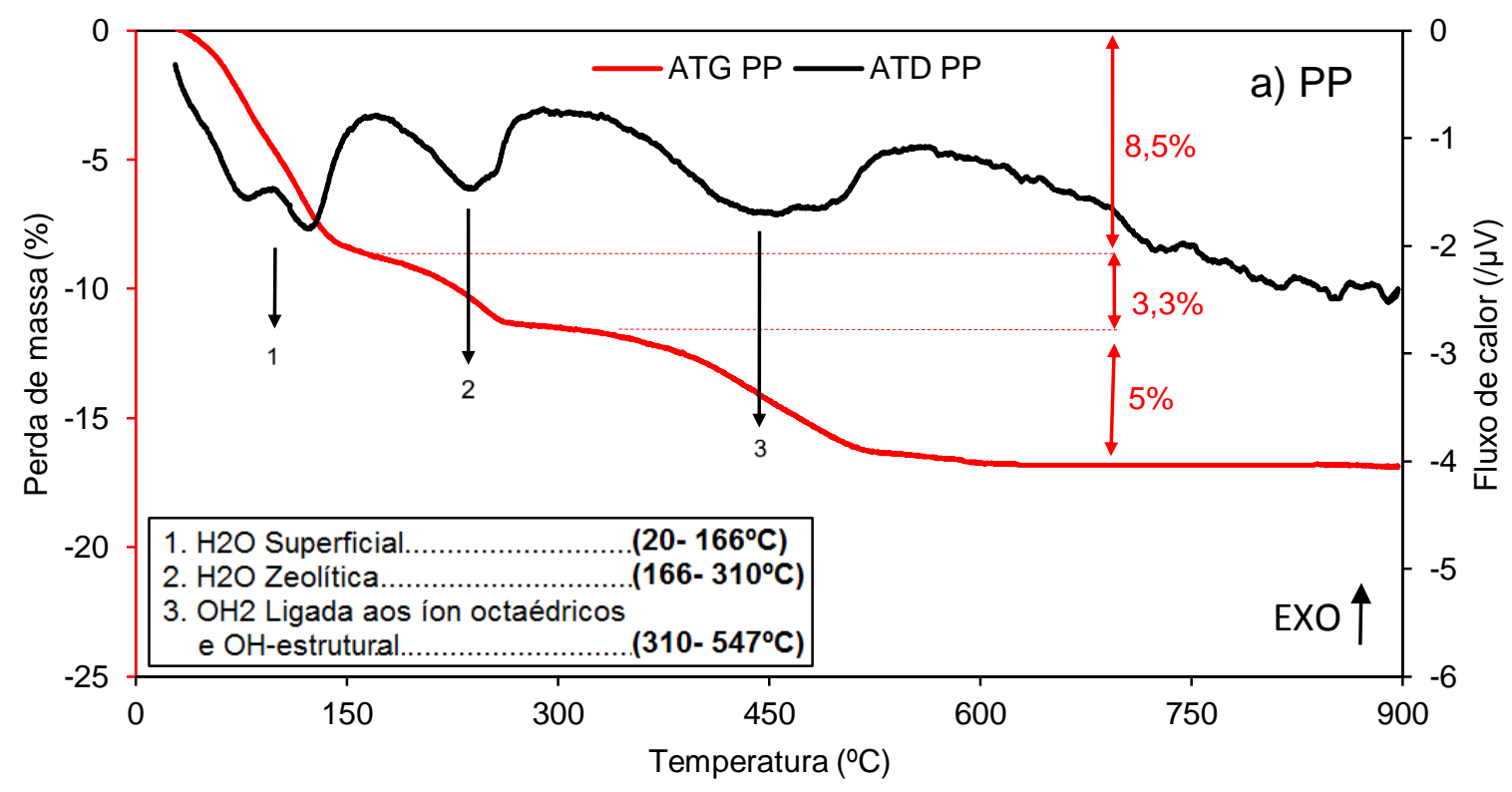




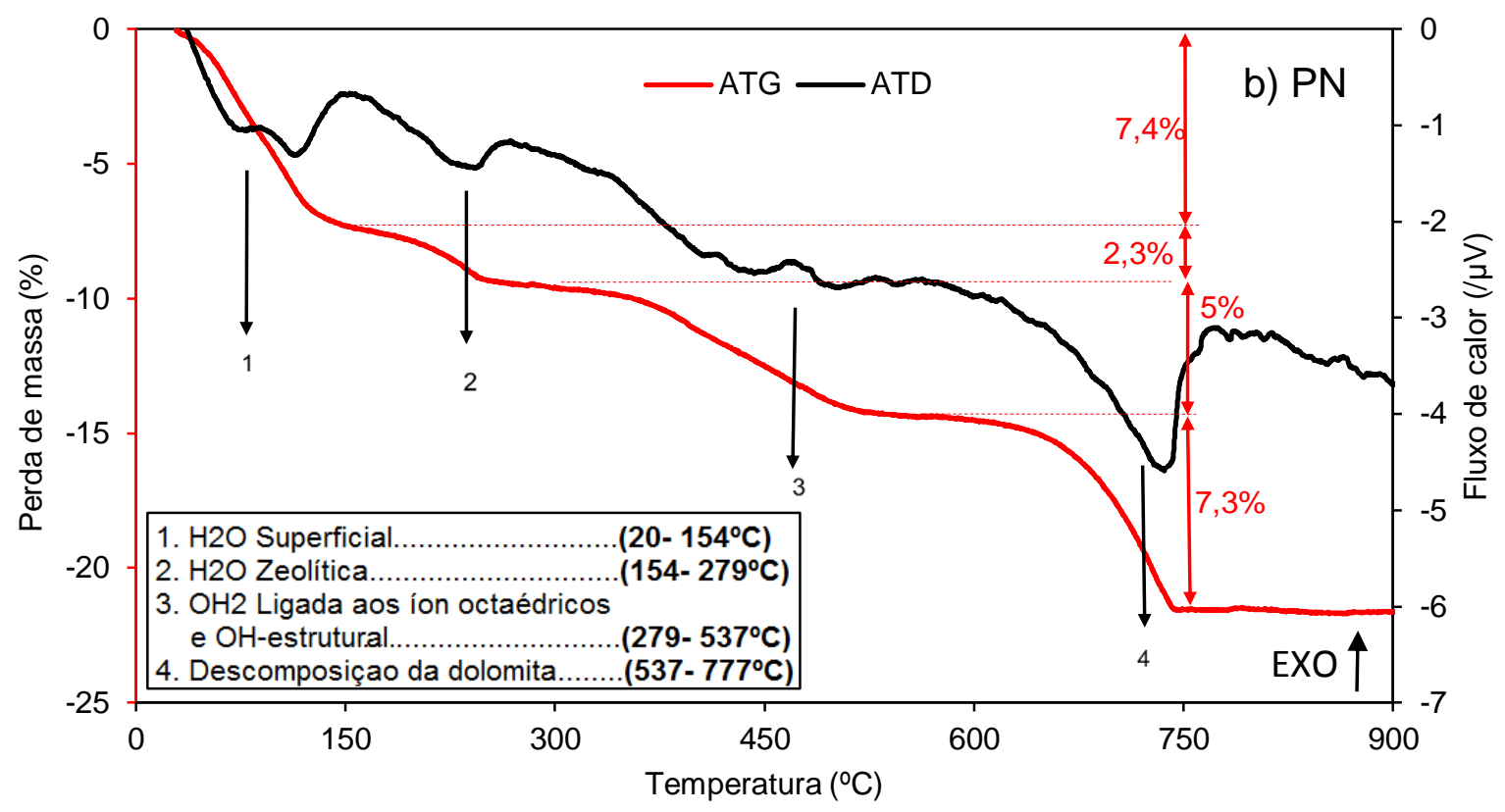

FIGURA 29 - Análises Termogravimétrico (ATG) e Termodiferencial (ATD) da paligorsquita: a) purificada (PP) e b) como recebida (PN).

Após o processo de purificação $(P P)$ a paligorsquita foi caracterizada analisando-se as curvas das isotermas de adsorção-dessorção de $\mathrm{N}_{2}$, e comparadas com a paligorsquita como recebida $(P M)$.

Observa-se no gráfico da FIG.30, que ocorre uma histerese entre as curvas de adsorção e de dessorção, tanto para a paligorsquita como recebida $(P N)$ como para a paligorsquita purificada $(P P)$, indicando a presencia de porosidade interna na estrutura. Segundo a classificação da IUPAC (IUPAC, 2014) corresponde a curva tipo IV, de modo que a histerese observada entre as curvas de adsorção e dessorção para valores de $\left(\mathrm{p} / \mathrm{p}_{0}\right)$ superiores a 0,5 indicam a presença de mesoporos (poros entre 2 e $50 \mathrm{~nm}$ ). 


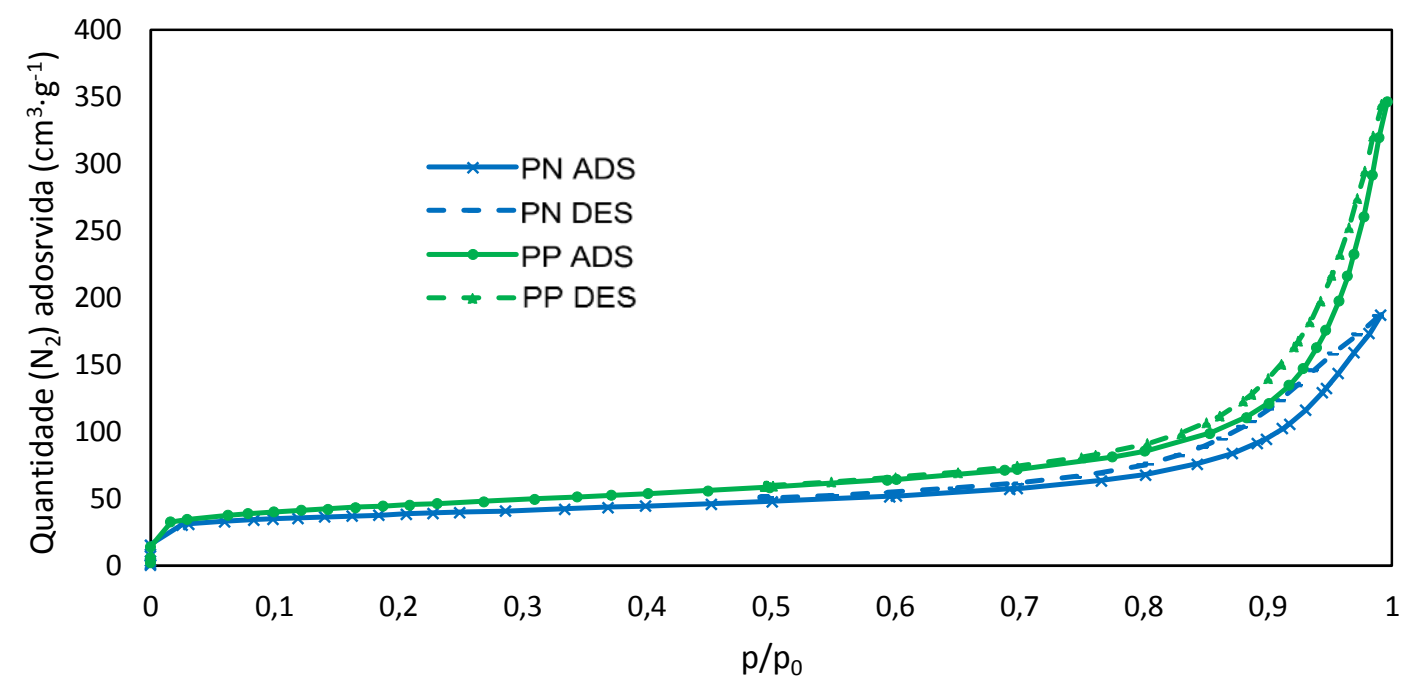

FIGURA 30 - Isotermas de adsorção (ADS) - dessorção (DES) de $\mathrm{N}_{2}$ da paligorsquita como recebida (PN) e purificada (PN).

Um aumento na quantidade de $\mathrm{N}_{2}$ adsorvido é observado após o processo de purificação.

Por meio dos valores obtidos das isotermas de adsorção-dessorção de $\mathrm{N}_{2}$ foram calculados os parâmetros texturais, a área superficial específica (BET) e os valores de área e volume dos microporos da amostra como recebida $(P N)$ e da purificada $(P P)$, listados na $T A B .18$.

TABELA 18 - Área superficial especifica, área e volume dos microporos e parâmetros físicos relacionados da paligorsquita como recebida (PN) e purificada (PP).

\begin{tabular}{cccccccc}
\hline AMOSTRA & $\begin{array}{c}\boldsymbol{S}_{\text {BET }} \\
\left(\mathrm{m}^{2} \cdot \mathrm{g}^{-1}\right)\end{array}$ & $\begin{array}{c}\boldsymbol{S}_{\text {ext }} \\
\left(\mathrm{m}^{2} \cdot \mathrm{g}^{-1}\right)\end{array}$ & $\begin{array}{c}\boldsymbol{S}_{\text {micro }} \\
\left(\mathrm{m}^{2} \cdot \mathrm{g}^{-1}\right)\end{array}$ & $\begin{array}{c}\boldsymbol{V}_{\text {TOTAL }} \\
\left(\mathrm{cm}^{3} \cdot \mathrm{g}^{-1}\right)\end{array}$ & $\begin{array}{c}\boldsymbol{V}_{\text {micro }} \\
\left(\mathrm{cm}^{3} \cdot \mathrm{g}^{-1}\right)\end{array}$ & $\begin{array}{c}\boldsymbol{V}_{\text {meso }} \\
\left(\mathrm{cm}^{3} \cdot \mathrm{g}^{-1}\right)\end{array}$ & $\begin{array}{c}\boldsymbol{d}_{\text {médio }} \\
(\mathrm{nm})\end{array}$ \\
\hline $\boldsymbol{P P}$ & 158,6 & 111,3 & 47,3 & 0,496 & 0,021 & 0,474 & 12,4 \\
$\boldsymbol{P N}$ & 137,7 & 83,3 & 54,3 & 0,280 & 0,023 & 0,257 & 8,3 \\
\hline
\end{tabular}

Atendendo aos resultados obtidos para a área $\left(S_{\text {micro }}\right)$ e volume dos microporos $\left(\mathrm{V}_{\text {micro }}\right)$ para as duas amostras, pode se afirmar que o processo de purificação foi efetivo na manutenção destes parâmetros físicos correspondentes aos microporos estruturais.

Contudo o processo de purificação gerou uma grande quantidade de mesoporos e macroporos, mas estes poros não são estruturais, podendo ter sido 
gerados pela nova disposição ou aglomeração das fibras de paligorsquita e pela dissolução da dolomita após o processo de purificação.

A remoção da dolomita e, portanto, o processo de purificação, resultou num aumento da superfície específica $\left(\mathrm{S}_{\mathrm{BET}}\right)$ de $13,15 \%$ para a amostra purificada $(P P)$.

As micrografias obtidas por MEV das amostras de paligorsquita como recebida (a) e após o processo de purificação (b) estão representadas na FIG.32. Na paligorsquita purificada (PP) apresentada na FIG.32.b, pode se observar a dissolução ou remoção das possíveis impurezas existentes entre as fibras, como dolomita, quando comparada com a recebida ( $P N)$ apresentada na FIG.32.a. A micrografia aleatória da amostra purificada (FIG.32.b) exibe uma morfologia fibrosa constituída por pequenos de bastonetes aciculares aglomerados com tamanho médio que varia de 0,2 a $2 \mu \mathrm{m}$ de comprimento.
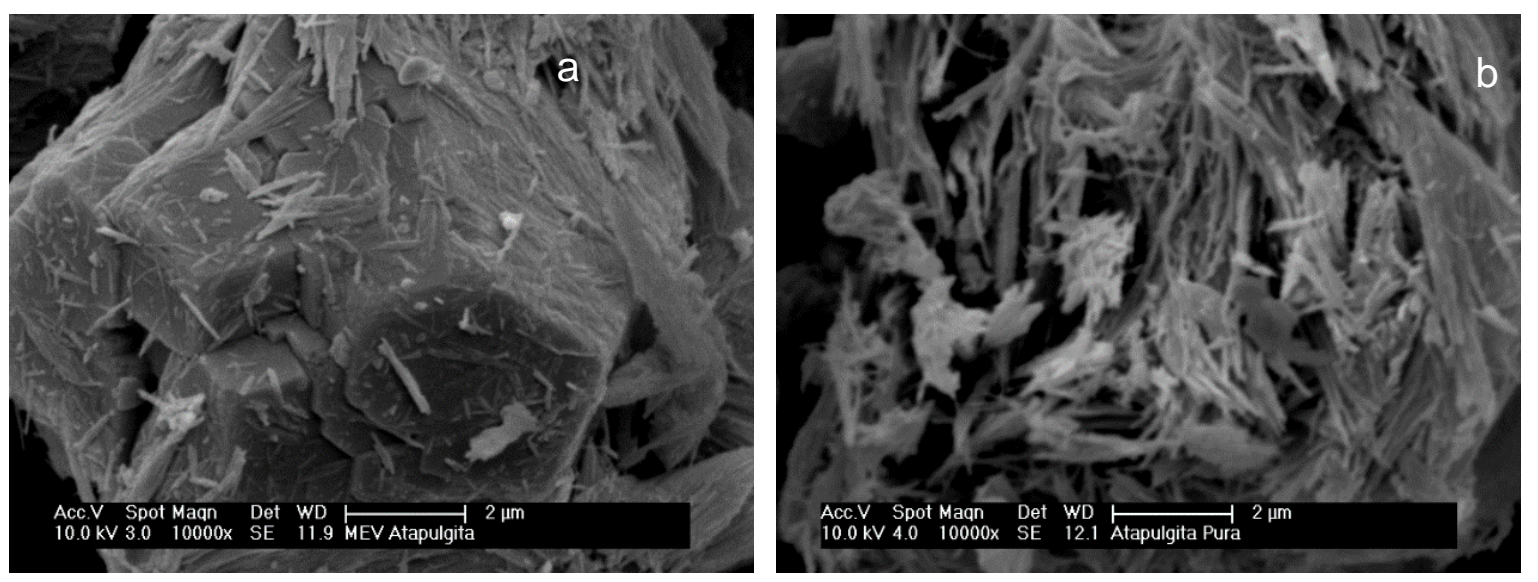

FIGURA 31 - Micrografias obtidas por MEV da amostra de paligorsquita (a) como recebida $(P N)$ e (b) purificada $(P P)$.

A FIG.32 ilustra as micrografias obtidas as partir das análises de microscopia eletrônica de transmissão (MET) para a paligorsquita purificada (PP). A análise da paligorsquita obtida por MET mostra uma estrutura fibrilar de ração $\varnothing: L=0,051 \pm$ 0,015 nm aproximadamente (analisando 7 campos), apresentando estruturas típicas dos nanotubos. 

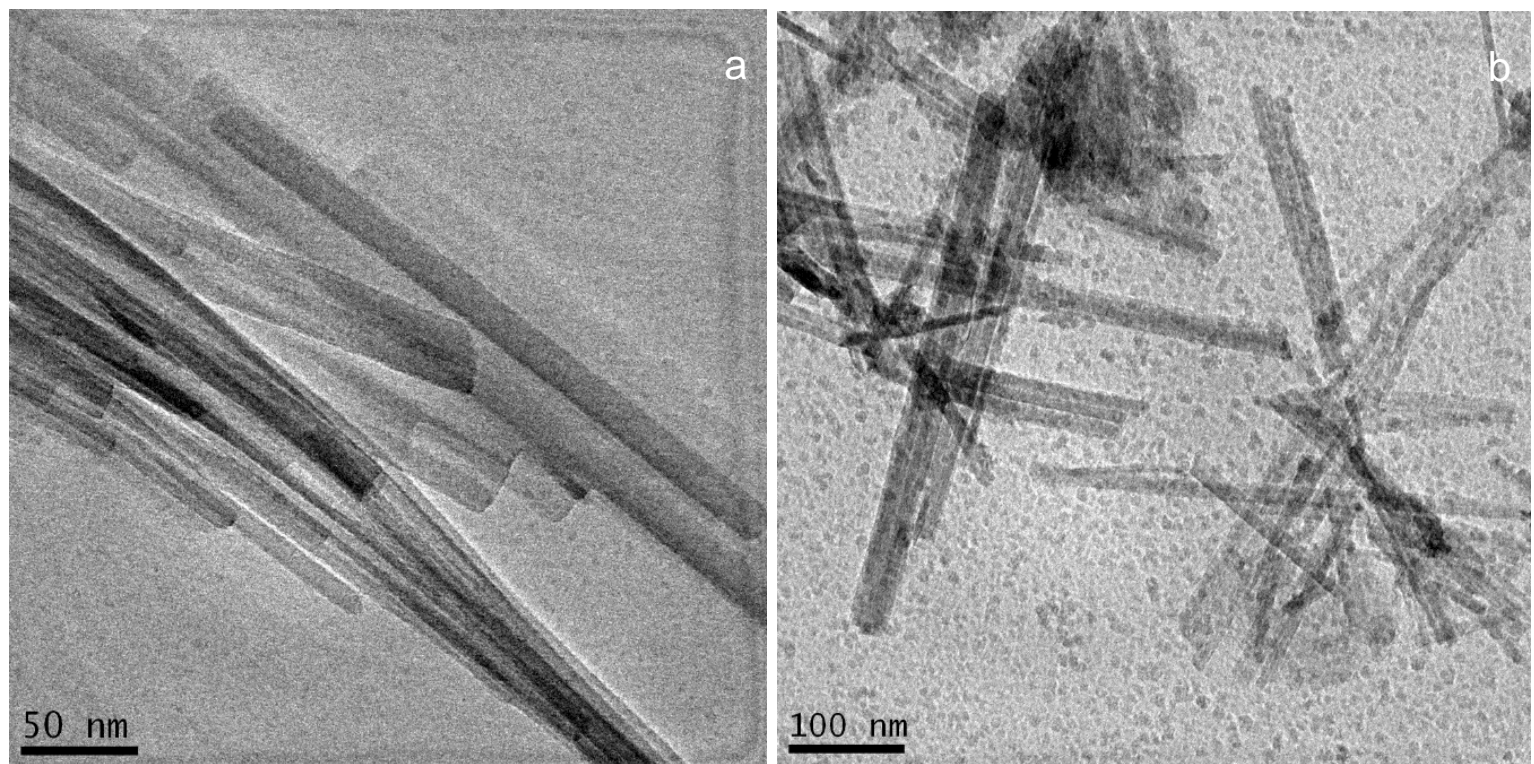

FIGURA 32 - Micrografias por microscopia eletrônica de transmissão da amostra de paligorsquita purificada (PP).

\subsection{Otimização do processo de colapso estrutural por tratamento térmico dos nanotubos naturais}

O estudo do tratamento térmico foi realizando visando determinar a temperatura ótima na qual produz-se o colapso estrutural dos nanotubos naturais da paligorsquita.

Após o processo de incorporação dos radionuclídeos simulados nos nanotubos que compõem a estrutura da paligorsquita, será necessário realizar o tratamento térmico a uma temperatura suficiente para produzir o colapso estrutural, imobilizando os cátions procedentes do rejeito radioativo dentro da matriz, como ilustrado na FIG.15.

A partir dos dados fornecidos pelas curvas $A T D / T G$ da paligorsquita purificada, foram selecionadas as temperaturas de 300, 550 e $800^{\circ} \mathrm{C}$, por tempos de 3 horas e foram analisados os principais acontecimentos por DRX, BET e FTIR.

Na FIG.33 compararam-se os espectros de DRX de paligorsquita (PP) e das amostras tratadas nas temperaturas selecionadas. 
Após aquecimento a $300^{\circ} \mathrm{C}$ por 3 horas para a amostra $P 300$ (FIG.33), a intensidade e a posição de cada reflexão da paligorsquita mantiveram-se constantes, indicando a estabilidade da estrutura.

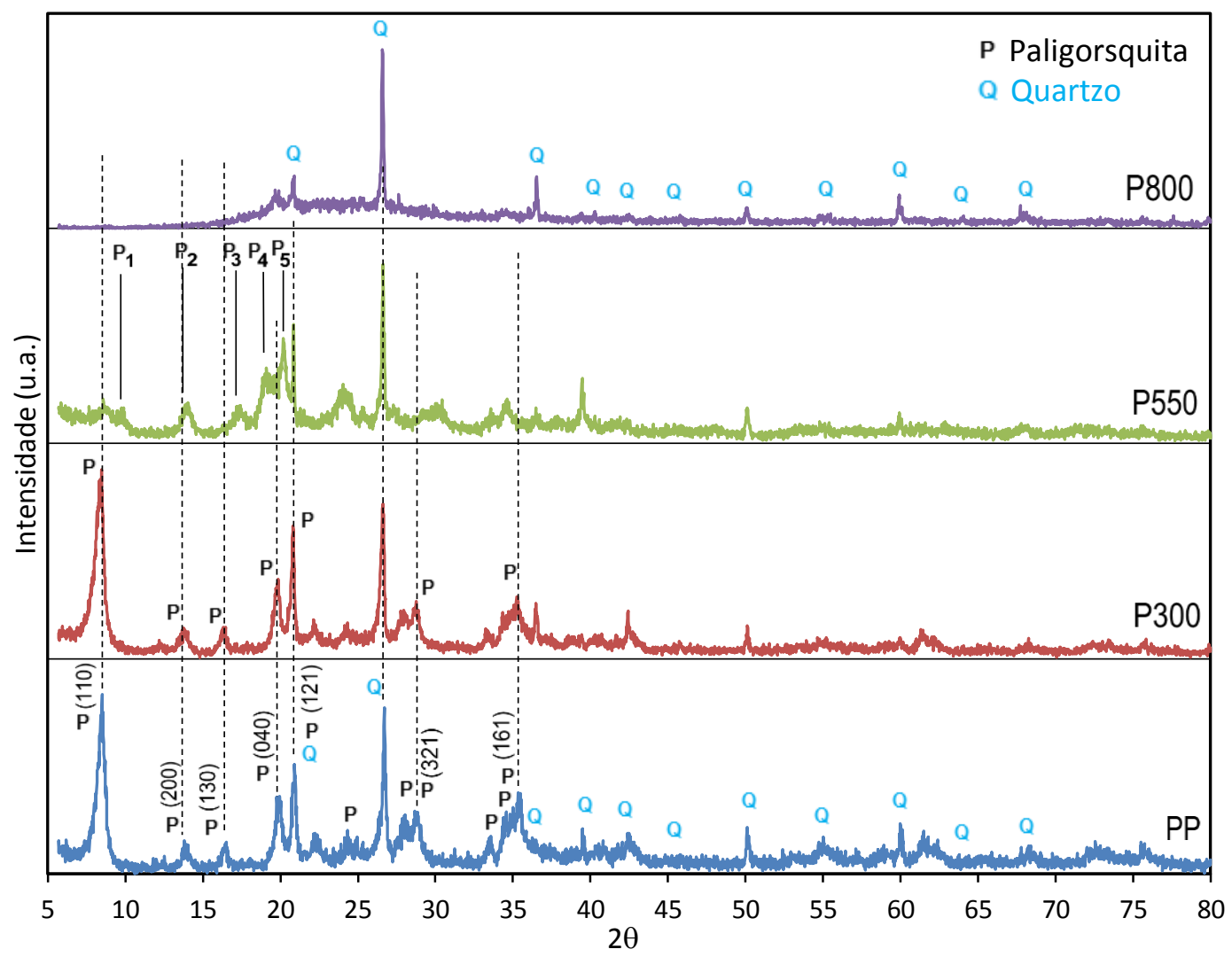

FIGURA 33 - Difratogramas de raios $X$ das amostras de paligorsquita tratadas termicamente (P300, P550 e P800) e a purificada (PP).

Após aquecimento a $550^{\circ} \mathrm{C}$ por 3 horas para a amostra $P 550$, podem se observar vários eventos no difratograma representado na FIG.33. Foi identificada a notável redução da intensidade correspondente às reflexões localizadas em (110), (321) e (161), atribuída a perda do grau de cristalinidade da estrutura. Nesta temperatura foram distinguidas duas novas reflexões, a primeira localizada em $2(\theta)=9,88^{\circ}$ de espaçamento $d=0,893 \mathrm{~nm}$ (identificado como $\mathrm{P}_{1}$ na FIG.33), causada pela desidratação da água ligada na estrutura e pela dehidroxilação das moléculas $\mathrm{OH}^{-}$também ligadas na estrutura, atribuída à deformação ou colapso estrutural na literatura (YAN, LIU, et al., 2012), e a segunda localizada em d =0,439 nm (identificada como $\mathrm{P}_{5}$ na $F / G$.33) segundo a literatura é uma reflexão característica da paligorsquita monoclínica (YAN, LIU, et al., 2012), o que sugere 
que a amostra tratada termicamente a $550^{\circ} \mathrm{C}$ é transformada da paligorsquita ortorrômbica para paligorsquita monoclínica. Podem se observar ao mesmo tempo deslocamentos das reflexões (200), (130) e (040) localizadas em d $d_{200}=0,640 \mathrm{~nm}$, $d_{130}=0,539 \mathrm{~nm}$ e $d_{040}=0,447 \mathrm{~nm}$ para a paligorsquita purificada, sendo deslocadas para $\mathrm{d}_{200}=0,629 \mathrm{~nm}$ (identificada como $\mathrm{P}_{2}$ na $F / G .33$ ), $\mathrm{d}_{130}=0,510 \mathrm{~nm}$ (identificada como $\mathrm{P}_{3}$ na FIG.33), e $\mathrm{d}_{040}=0,463 \mathrm{~nm}$ (identificada como $\mathrm{P}_{4}$ na $F / G .33$ ), respectivamente. Segundo YAN, LIU, et al. (2012), a identificação da reflexão (200) indica a existência de estrutura em camadas.

Após aquecimento a $800^{\circ} \mathrm{C}$ por 3 horas para a amostra P800 (FIG.33), praticamente todas as reflexões características da paligorsquita purificada desaparecem. As reflexões correspondentes ao quartzo (identificado como $Q$ na FIG.33), caracterizado pela difração a aproximadamente $(2 \theta)=27^{\circ}$ na amostra (PP), continua aparecendo no difratograma da amostra $P 800$ junto com todas as suas reflexões características identificadas na fixa de difração correspondente ao quartzo alfa ICDD- 065-0466.

A difração de raios $X$ da amostra $P 550$ apresenta variações estruturais atribuídas pela literatura ao colapso ou "folding" estrutural da paligorsquita (YAN, LIU, et al., 2012).

Estas modificações são claramente evidenciadas analisando os espectros obtidos por FTIR para as amostras nas diferentes condições de temperatura estabelecidas.

Os espectros de FTIR da paligorsquita purificada e após tratamento térmico nas temperaturas de 300,550 e $800^{\circ} \mathrm{C}$ por 3 horas, estão representados na FIG.34.

As principais bandas energéticas correspondes aos grupos característicos da paligorsquita foram identificados anteriormente na TAB.14 (item 5.1.3), e as modificações sofridas nestas bandas após tratamento térmico foram estudadas e representadas na FIG. 34, observando-se os seguintes eventos:

Após tratamento térmico $300^{\circ} \mathrm{C} / 3 \mathrm{~h}$ no espectro da amostra P300 (FIG.34), foram identificadas todas as bandas de vibração correspondentes à paligorsquita purificada $P P$. 


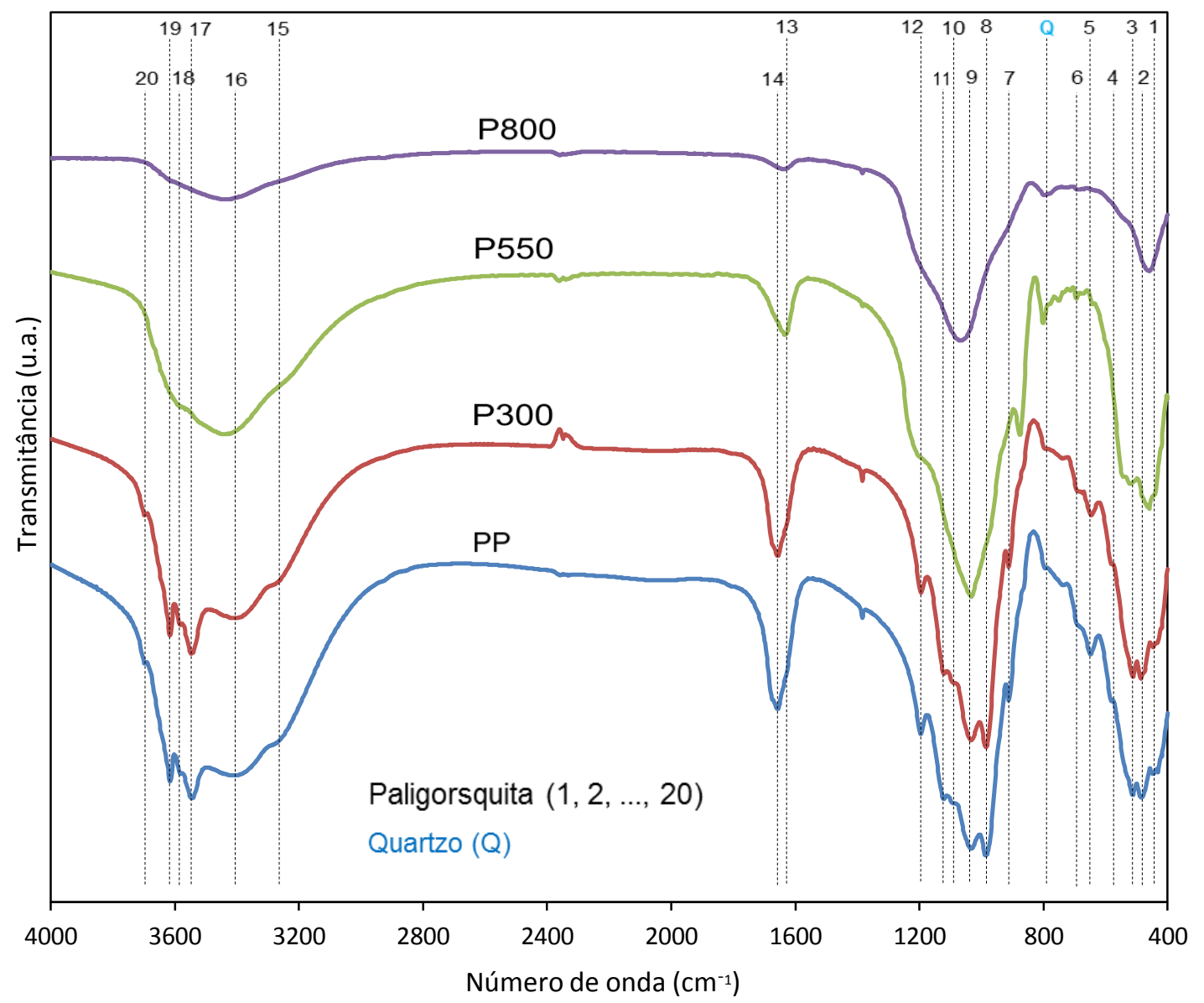

FIGURA 34 - Espectro Infravermelho da paligorsquita purificada (PP) e das amostras tratadas termicamente (P300, P550, P800).

Após tratamento térmico $550^{\circ} \mathrm{C} / 3 \mathrm{~h}$ no espectrograma da amostra $P 550$ (FIG.34), não foram identificadas as bandas de vibração correspondentes ao estiramento do metal ( $\mathrm{Mg}$, $\mathrm{Al}$ ou $\mathrm{Fe}$ ) ligado aos grupos hidroxilos (M-OH) localizadas a 3582, 3615, 3653 e $3997 \mathrm{~cm}^{-1}$ (identificadas como 18, 19, 20 e 21 na FIG.34 respectivamente), nem as bandas correspondentes as vibrações de estiramento e flexão da molécula $\mathrm{OH}_{2}$ ligada na estrutura, localizadas a $3545 \mathrm{~cm}^{-1}$ e $1653 \mathrm{~cm}^{-1}$ (identificadas como 17 e 14 na FIG.34 respectivamente). Segundo a literatura estas bandas não foram reconhecidas por causa da desidratação e a deshidroxilação a $550^{\circ} \mathrm{C}$, resultando na distorção progressiva da estrutura. A banda a $1093 \mathrm{~cm}^{-1}$ (identificada como 10 na $F / G .34$ ) atribuída à vibração de estiramento da base tetraédrica $\mathrm{SiO}_{4}$ da paligorsquita não foi identificada na amostra ( $\left.P 550\right)$ tratada a $550^{\circ} \mathrm{C}$. A literatura atribui este efeito à distorção da camada tetraédrica. Estes fatos concordam com a análise ATD/TG (FIG. 29.a) onde se observa um 
evento endotérmico $\left(279-527^{\circ} \mathrm{C}\right)$ associado a uma perda de $7 \%$ de massa, e com o difratograma de raios $\mathrm{X}$ da amostra na condição $P 550$ onde ainda pode se observar a reflexão característica do plano basal da paligorsquita, o que poderia indicar a existência da estrutura em camadas apesar da diminuição do grau de cristalinidade, confirmado a modificação estrutural. Nesta temperatura a banda característica da paligorsquita a $1196 \mathrm{~cm}^{-1}$ (identificada como 12 na FIG.34), diminui gradualmente a sua intensidade deslocando-se para comprimentos de onda inferiores (até $1142 \mathrm{~cm}^{-1}$ ), mas ainda aparece como uma banda ombro, o que está de acordo com YAN, LIU, et al. (2012), atribuído à existência de variação estrutural indicativa do colapso ou "folding".

Após tratamento térmico a $800^{\circ} \mathrm{C} / 3 \mathrm{~h}$ no espectrograma da amostra $P 800$ continuam existindo as bandas de vibração das ligações da camada tetraédrica relacionadas com o esqueleto da paligorsquita $\mathrm{SiO}_{4}$ a 478, 1084 e $1240 \mathrm{~cm}^{-1}$ (identificadas como 2, 10 e 13 na FIG.34) no entanto as bandas características das vibrações correspondentes às ligações dos metais presentes no argilomineral (Mg, $\mathrm{Al}, \mathrm{Fe}$ ) não foram identificadas.

As variações estruturais apresentadas nas condições de temperaturas estudadas por DRX e FT-IR evidenciam a ocorrência da possível modificação estrutural na temperatura de $550^{\circ} \mathrm{C}$. Entretanto, as amostras nas diferentes condições de tratamento térmico foram analisadas para observar a evolução da área superficial específica e dos parâmetros de área e volume dos microporos para cada condição, com o objetivo de verificar que as modificações estruturais identificadas anteriormente correspondem a um possível colapso estrutural.

Os resultados obtidos e calculados da área superficial específica, área superficial externa, área dos microporos e volume dos microporos estão apresentados na TAB.19.

Os parâmetros de área e volume dos microporos evoluem significativamente durante o tratamento térmico, como pode se observar na FIG.35.

$\mathrm{Na}$ FIG.35.a, pode se apreciar a significativa redução do valor correspondente a área superficial especifica à medida que a temperatura é aumentada, apresentando uma diminuição drástica a partir de $550^{\circ} \mathrm{C}$ até chegar a $10,6 \mathrm{~m}^{2} / \mathrm{g}$ para a condição de tratamento térmico de $800^{\circ} \mathrm{C}$. Observa-se que até a temperatura de $550^{\circ} \mathrm{C}$ a área superficial externa mantem-se constante e a área superficial correspondente aos microporos diminui gradualmente, sendo esta última 
a variável que modifica o valor de área superficial especifica e, portanto, variando de forma paralela.

TABELA 19 - Área superficial específica e área e volume dos microporos das amostras tratadas termicamente e da amostra purificada.

\begin{tabular}{ccccc}
\hline CONDIÇÃO & $\begin{array}{c}S_{\text {BET }} \\
\left(\mathrm{m}^{2} \cdot g^{-1}\right)\end{array}$ & $\begin{array}{c}S_{\text {ext }} \\
\left(\mathrm{m}^{2} \cdot \mathrm{g}^{-1}\right)\end{array}$ & $\begin{array}{c}S_{\text {micro }} \\
\left(\mathrm{m}^{2} \cdot \mathrm{g}^{-1}\right)\end{array}$ & $\begin{array}{c}\boldsymbol{V}_{\text {micro }} \\
\left(\mathrm{cm}^{3} \cdot \mathrm{g}^{-1}\right)\end{array}$ \\
\hline $\boldsymbol{P P}$ & 158,6 & 111,3 & 47,3 & 0,0214 \\
$\boldsymbol{P 3 0 0}$ & 139,0 & 113,6 & 25,4 & 0,0119 \\
P550 & 113,1 & 109,2 & 3,9 & 0,0024 \\
$\boldsymbol{P 8 0 0}$ & 11,0 & 10,7 & 0,3 & 0,00002 \\
\hline
\end{tabular}

A FIG.35.b, apresenta a evolução do volume dos microporos frente à temperatura. Na FIG.35.b, pode se notar um comportamento similar entre a evolução de volume e área dos microporos analisados na FIG.35.b. O volume dos microporos apresenta uma diminuição progressiva e mais acentuada até à temperatura de $550^{\circ} \mathrm{C}$. A partir de $550^{\circ} \mathrm{C}$ a diminuição do volume dos microporos se estabiliza devido à perda de microporosidade.
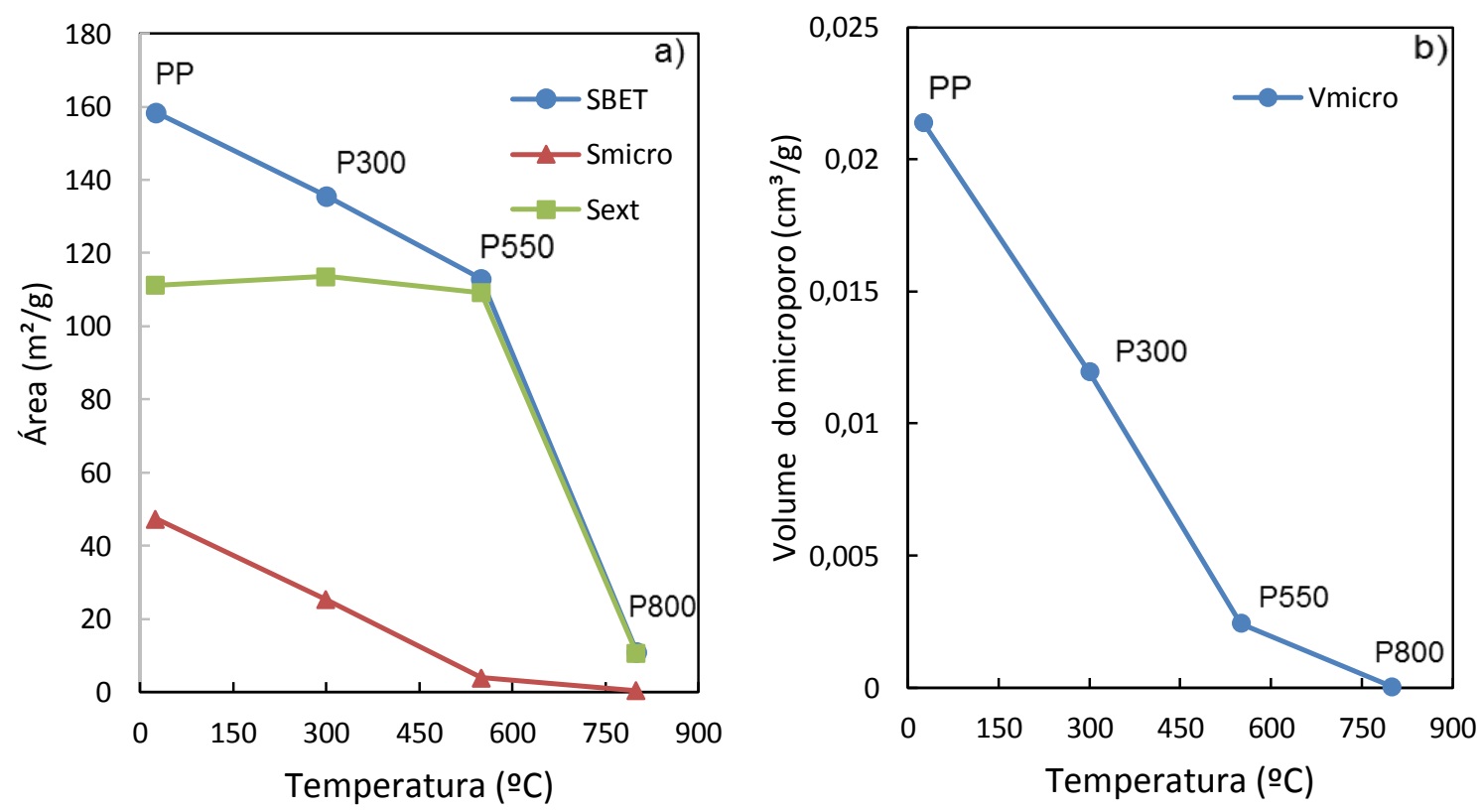

FIGURA 35 - Evolução da área superficial especifica (a) e volume do microporo (b) das amostras tratadas termicamente. 
Estes eventos onde podem se observar a diminuição acentuada dos valores de área e volume dos microporos para a condição de temperatura de $550^{\circ} \mathrm{C}$, da amostra P550, estão causados pela perda progressiva das moléculas de água e dos grupos hidroxilos, como foi observado com a técnica FT-IR e deste modo, as variações estruturais identificadas na difração de raios $X$ podem se atribuir ao colapso ou "folding" estrutural, de acordo com a literatura (YAN, LIU, et al., 2012).

$\mathrm{Na}$ FIG.36 representam-se as micrografias por MET da amostra tratada termicamente na condição de temperatura/tempo de 550\%/3h (P550). Nela pode se observar a preservação da estrutura fibrilar em camadas mantendo a morfologia original na forma da nanotubos, na qual a razão $\varnothing: L=0,038 \pm 0,009 \mathrm{~nm}$ aproximadamente (analisando 3 campos), mostrou-se inferior que para a amostra purificada $(P P)$.
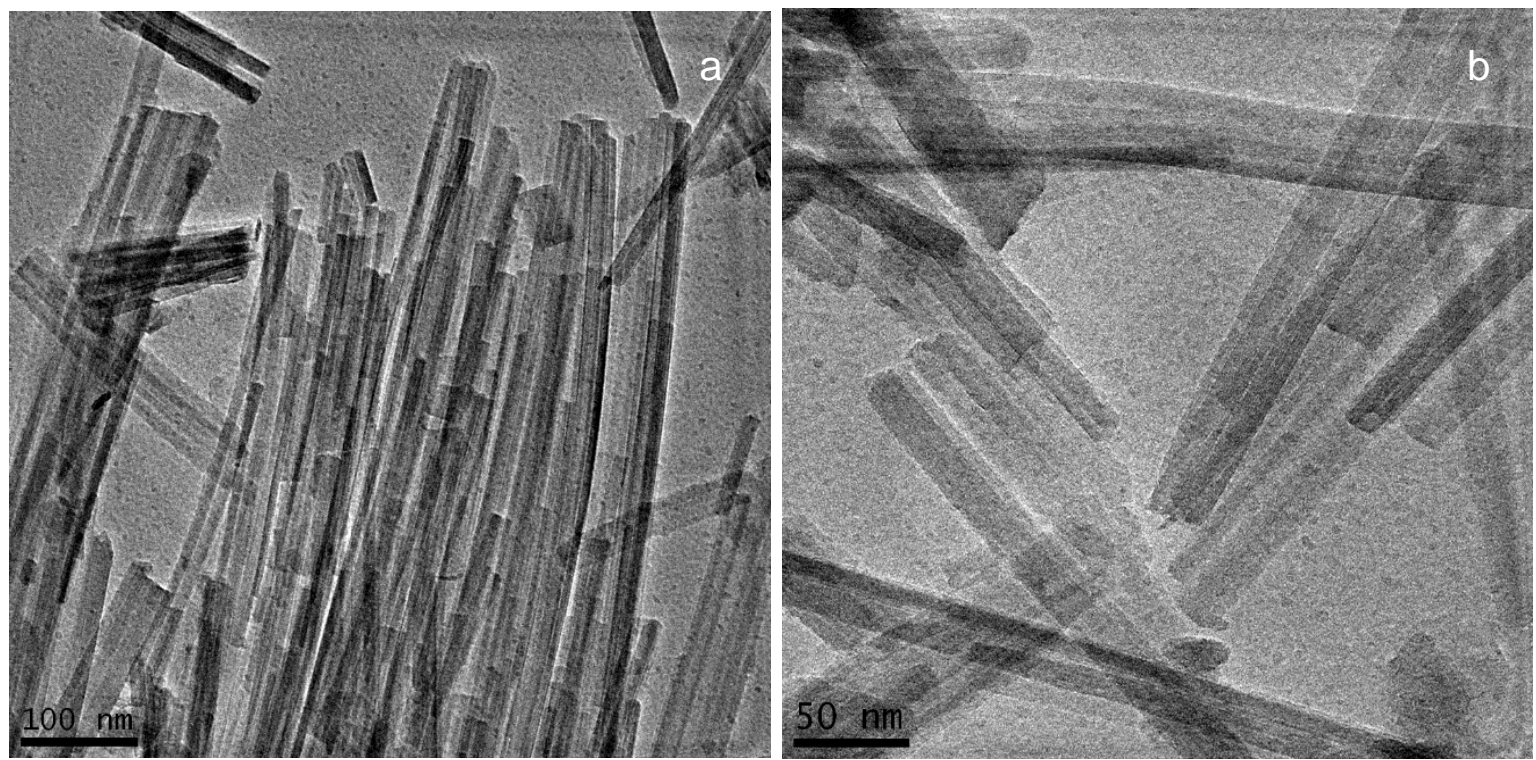

FIGURA 36 - Micrografias obtidas por MET a partir da amostra P550.

$\mathrm{Na} T A B .20$ representa-se a condição otimizada dentre as estudadas de colapso estrutural por tratamento térmico dos nanotubos naturais da paligorsquita.

TABELA 20 - Condição otimizada de colapso estrutural por tratamento térmico.

\begin{tabular}{ccc}
\hline Condição otimizada de colapso estrutural & Temperatura $\left({ }^{\circ} \mathrm{C}\right)$ & Tempo $(h)$ \\
\hline P550 & 550 & 3 \\
\hline
\end{tabular}




\subsection{Otimização do processo de ativação ácida dos nanotubos naturais}

O processo de ativação ácida foi selecionado para ativar as superfícies externas e internas dos nanotubos preservando-se a estrutura original do argilomineral. Esta ativação se dá pela remoção das espécies catiônicas das camadas octaédricas, gerando sítios ativos de cargas descompensadas capazes de sorver os cátions afins a estes sítios presentes nos efluentes estudados.

A ativação ácida na paligorsquita pode produzir a desagregação de cristais, a amorfização da estrutura, modifica a composição química, gera sítios ativos $\mathrm{OH}^{-}$ na superfície e interior dos nanotubos e altera a área superficial especifica (MYRIAM, SUÁREZ-BARRIOS e MARTIN-POZAS, 1998).

$O$ resultado da análise química semiquantitativa por $F R X-E D S$ das amostras obtidas das diversas condições de ativação ácida realizadas, variando as concentrações de ácido clorídrico ( $3,6,9$ e $\left.12 \mathrm{~mol} \cdot \mathrm{L}^{-1}\right)$, temperatura (60 e $90^{\circ} \mathrm{C}$ ) e tempo de ativação de (1 e 4 horas), segundo foi estabelecido no processo experimental deste trabalho (item 4.3), encontra-se representado na TAB.9.

Preliminarmente, a ativação ácida foi realizada na temperatura ambiente com as mesmas condições de tempo e concentrações de ácido planejados neste trabalho. Os resultados mostraram que a lixiviação foi de apenas 10\% em massa de $\mathrm{Mg}$, considerado insuficiente para a paligorsquita.

O silício é o constituinte dominante dos argilominerais e se encontra principalmente na camada tetraédrica, estável e é relativamente resistente ao ataque ácido (FRINI-SRASRA e SRASRA, 2010; ZHANG, WANG, et al., 2010; MYRIAM, SUÁREZ-BARRIOS e MARTIN-POZAS, 1998; CORMA, MIFSUD e SANZ, 1987; SUÁREZ-BARRIOS, GONZÁLES, et al., 1995).

MYRIAM, SUÁREZ-BARRIOS e MARTIN-POZAS (1998), estudaram a condição de tratamento mais agressiva de $9 \mathrm{~mol} \cdot \mathrm{L}^{-1}$, na temperatura de ebullição $\left(100^{\circ} \mathrm{C}\right)$ por 1 hora, posteriormente mantida a solução por 4 horas à temperatura ambiente. $O$ resultado da composição química da paligorsquita ativada por esta rota foi de $96,31 \%$ de $\mathrm{SiO}_{2}$ presente. Segundo estes autores, a sílica procede da dissoluçao parcial da camada tetraédrica da paligorsquita, identificada como sílica amorfa, do quartzo e de outros silicatos insolúveis acumulados no sólido ativado.

Como pode se observar nos resultados obtidos por FRX-EDS apresentados na $T A B .21$, o conteúdo de $\mathrm{SiO}_{2}$ aumenta com o aumento da dissolução dos óxidos 
de magnésio, ferro e alumínio possivelmente localizados na camada octaédrica da paligorsquita, como mostra a estrutura (FIG.14). Não obstante, pode se apreciar que a concentração dos óxidos de ferro (III) e de magnésio diminuem de forma mais acentuada que a concentração do óxido de alumínio.

TABELA 21 - Resultados das análises químicas (FRX-EDS) da amostra como recebida, purificada e ativadas em diferentes condições de $\mathrm{CM}=$ concentração molar $\left(\mathrm{mol} \cdot \mathrm{L}^{-1}\right), \mathrm{T}=$ temperatura $\left({ }^{\circ} \mathrm{C}\right)$ e $\mathrm{t}=$ tempo $(\mathrm{h})$.

\begin{tabular}{|c|c|c|c|c|c|c|c|c|c|c|c|}
\hline \multicolumn{4}{|c|}{ CONDIÇÃO } & \multicolumn{8}{|c|}{ Composição (\% em massa)* } \\
\hline Id. & $C M$ & $T$ & $t$ & $\mathrm{SiO}_{2}$ & $\mathrm{Al}_{2} \mathrm{O}_{3}$ & MgO & $\mathrm{Fe}_{2} \mathrm{O}_{3}$ & $\mathrm{CaO}$ & $\mathrm{K}_{2} \mathrm{O}$ & $\mathrm{TiO}_{2}$ & MnO \\
\hline$P P$ & & & & 65,6 & 15,7 & 8,9 & 7,2 & ND & 1,4 & 0,8 & 0,4 \\
\hline$P 1$ & 3 & 60 & 1 & 67,4 & 15,7 & 8,1 & 6,2 & ND & 1,3 & 1,1 & 0,08 \\
\hline$P 2$ & 3 & 60 & 4 & 74,4 & 13,3 & 6,7 & 3,7 & ND & 0,6 & 1.14 & 0,05 \\
\hline P3 & 3 & 90 & 1 & 69,3 & 15,1 & 7,8 & 5,4 & ND & 1,2 & 1,1 & 0.05 \\
\hline$P 4$ & 3 & 90 & 4 & 81,5 & 11,4 & 6,2 & 0,3 & ND & 0,3 & 0,3 & 0,01 \\
\hline P5 & 6 & 60 & 1 & 68,5 & 15,0 & 7,8 & 6,2 & ND & 1,3 & 1,2 & 0.07 \\
\hline P6 & 6 & 60 & 4 & 76,1 & 12,8 & 6,5 & 3,0 & ND & 0,5 & 1.1 & 0,03 \\
\hline$P 7$ & 6 & 90 & 1 & 72,0 & 14,0 & 7,2 & 4,7 & ND & 1,0 & 1,1 & 0,05 \\
\hline$P 8$ & 6 & 90 & 4 & 84,7 & 9,4 & 5,4 & 0,3 & ND & 0,2 & 1,0 & 0,01 \\
\hline$P 9$ & 9 & 60 & 1 & 68,6 & 15,2 & 7,6 & 6,2 & ND & 1,3 & 1,1 & 0,07 \\
\hline P10 & 9 & 60 & 4 & 77,5 & 11,2 & 5,8 & 2,3 & ND & 0,5 & 1,1 & 0,03 \\
\hline P11 & 9 & 90 & 1 & 72,4 & 14,4 & 6,9 & 4,1 & ND & 1.1 & 0,9 & 0,04 \\
\hline P12 & 9 & 90 & 4 & 82,2 & 10,0 & 4,8 & 1,7 & ND & 0,3 & 0,2 & 0,01 \\
\hline P13 & 12 & 60 & 1 & 70,5 & 14,4 & 7,0 & 5,5 & ND & 1,3 & 1,1 & 0,06 \\
\hline P14 & 12 & 60 & 4 & 77,8 & 12,2 & 6,0 & 2,5 & ND & 0,5 & 1,0 & 0,03 \\
\hline P15 & 12 & 90 & 1 & 77,3 & 12,4 & 5,8 & 1,8 & ND & 0,6 & 1,0 & 0,03 \\
\hline P16 & 12 & 90 & 4 & 86,8 & 7,4 & 3,5 & 1,0 & ND & 0,3 & 0,9 & 0,01 \\
\hline
\end{tabular}

${ }^{*}$ Percentagem em massa sem avaliar a Perda ao Fogo a $900^{\circ} \mathrm{C}$. $N D=$ Não detectado.

Devido à relativa resistência do $\mathrm{SiO}_{2}$ da camada tetraédrica ao ataque ácido, pode-se utilizar a relação, $F_{N}$, como um fator de normalização, entre a composição total de $\% \mathrm{SiO}_{2}$ existente na amostra purificada de referência $(P P)$ e a composição total de $\% \mathrm{SiO}_{2}$ existente em cada amostra ativada $\left(P_{i}\right)$, necessário para normalizar e comparar os resultados obtidos neste trabalho com maior confiabilidade. 
Ressaltando ainda que este fator de normalização foi utilizado considerando que a técnica $F R X$-EDS sempre avalia os resultados baseando-se na massa total de cada amostra.

O fator de Normalização, $F_{N}$, foi aplicado a cada amostra ativada (i=1, 2, ...,16) conforme a $E Q .18$, para poder avaliar a quantidade de cátions de magnésio normalizados removidos das amostras ativadas de acordo com a EQ.19. O mesmo processo de normalização será abordado para as demais espécies de interesse (alumínio e ferro). Na TAB.22 representa-se a concentração normalizada de magnésio, ferro e alumínio removidos por lixiviação em função das concentrações iniciais.

$$
F_{N_{i}}=\frac{\operatorname{SiO}_{2}(P P)}{\operatorname{SiO}_{2}\left(P_{i}\right)} \quad i=(1,2, \ldots, 16)
$$

Onde: $F_{N i}$ é o fator de normalização aplicado para cada amostra ativada ( $\mathrm{i}=1$, $2, \ldots, 16)$

$\mathrm{SiO}_{2}(\mathrm{PP})$, é a composição de $\% \mathrm{SiO}_{2}$ presente na amostra purificada.

$\mathrm{SiO}_{2}(\mathrm{Pi})$, é a composição de $\% \mathrm{SiO}_{2}$ da amostra ativada $(\mathrm{i}=1,2, \ldots, 16)$.

$$
M g_{N i}=\frac{M g O(P P)-F_{N i} \cdot \operatorname{MgO}\left(P_{i}\right)}{M g O(P P)} \quad i=(1,2, \ldots, 16)
$$

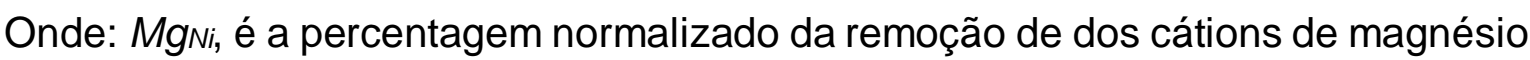
da amostra de ativada $(i=1,2, \ldots, 16)$.

$M g O(P P)$, é a composição de \%MgO da amostra purificada $(P P)$.

$\mathrm{MgO}(\mathrm{Pi})$, é a composição de \%MgO da amostra ativada $(\mathrm{i}=1,2, \ldots, 16)$

$F_{N}$, é o fator de normalização. 
TABELA 22 - Fator de normalização $\left(F_{N}\right)$ e percentagens normalizados dos cátions de magnésio $\left(\mathrm{Mg}_{\mathrm{N}}\right)$, ferro $\left(\mathrm{Fe}_{\mathrm{N}}\right)$ e alumínio $(\mathrm{Al} / \mathrm{N})$ removidos para cada condição.

\begin{tabular}{ccccc}
\hline CONDIÇÃO & $\boldsymbol{F}_{\boldsymbol{N}}$ & $\boldsymbol{M g}_{\boldsymbol{N}}$ & $\boldsymbol{F} \boldsymbol{e}_{\boldsymbol{N}}$ & $\boldsymbol{A} \boldsymbol{I}_{\boldsymbol{N}}$ \\
\hline $\boldsymbol{P 1}$ & 0,97 & $11,4 \%$ & $16,2 \%$ & $2,4 \%$ \\
$\boldsymbol{P 2}$ & 0,88 & $33,3 \%$ & $55,2 \%$ & $25,0 \%$ \\
$\boldsymbol{P 3}$ & 0,95 & $16,8 \%$ & $29,8 \%$ & $8,7 \%$ \\
$\boldsymbol{P 4}$ & 0,80 & $44,0 \%$ & $96,6 \%$ & $41,4 \%$ \\
$\boldsymbol{P 5}$ & 0,96 & $16,4 \%$ & $17,5 \%$ & $8,6 \%$ \\
$\boldsymbol{P 6}$ & 0,86 & $36,9 \%$ & $64,5 \%$ & $29,9 \%$ \\
$\boldsymbol{P 7}$ & 0,91 & $26,7 \%$ & $40,9 \%$ & $18,5 \%$ \\
$\boldsymbol{P 8}$ & 0,77 & $53,3 \%$ & $96,4 \%$ & $53,7 \%$ \\
$\boldsymbol{P 9}$ & 0,96 & $18,4 \%$ & $17,9 \%$ & $7,3 \%$ \\
$\boldsymbol{P 1 0}$ & 0,85 & $44,4 \%$ & $73,6 \%$ & $39,7 \%$ \\
$\boldsymbol{P 1 1}$ & 0,91 & $29,5 \%$ & $48,4 \%$ & $16,8 \%$ \\
$\boldsymbol{P 1 2}$ & 0,80 & $56,6 \%$ & $80,6 \%$ & $49,1 \%$ \\
$\boldsymbol{P 1 3}$ & 0,93 & $27,2 \%$ & $28,5 \%$ & $14,4 \%$ \\
$\boldsymbol{P 1 4}$ & 0,84 & $43,4 \%$ & $70,9 \%$ & $34,2 \%$ \\
$\boldsymbol{P 1 5}$ & 0,85 & $44,3 \%$ & $78,7 \%$ & $32,6 \%$ \\
$\boldsymbol{P 1 6}$ & 0,76 & $69,9 \%$ & $89,9 \%$ & $64,6 \%$ \\
\hline & & & &
\end{tabular}

A FIG.37 apresenta os resultados da remoção do Magnésio obtidos durante o processo de ativação em função do tempo para temperaturas de ativação de $60^{\circ}$ e 90 $\mathrm{C}$ e concentrações de ácido variando de 3, 6, 9 e $12 \mathrm{~mol} \cdot \mathrm{L}^{-1}$. Observa-se na FIG.37. a que, mantendo-se a temperatura constante e igual a $60^{\circ} \mathrm{C}$, a remoção dos cátions de magnésio aumenta com o tempo de tratamento. Também se observa para um mesmo tempo de ensaio a quantidade de magnésio removido aumenta com o aumento da concentração de ácido utilizada. A mesma tendência à remoção é observada quando se utiliza nos ensaios a temperatura de $90^{\circ} \mathrm{C}$ (FIG.37.b). Porém nestas condições, ou seja, quando se utiliza temperatura de $90^{\circ} \mathrm{C}$, o rendimento da ativação por remoção de $\mathrm{Mg}^{2+}$ é maior em todas as condições ensaiadas quando comparada à temperatura de $60^{\circ}$. 
Observando-se o comportamento das curvas de remoção de magnésio em função do tempo, reportadas na FIG.37, verifica-se que em quase todas as condições, em ambas figuras (a) e (b), ocorre uma mudança de inclinação nas curvas que pode estar relacionada com a mudança de comportamento cinético de extração de magnésio. Ressaltando que a relação volume de solução e sólido (argila) de 10:1, é elevada o suficiente para evitar a saturação da solução pela remoção do cátion.
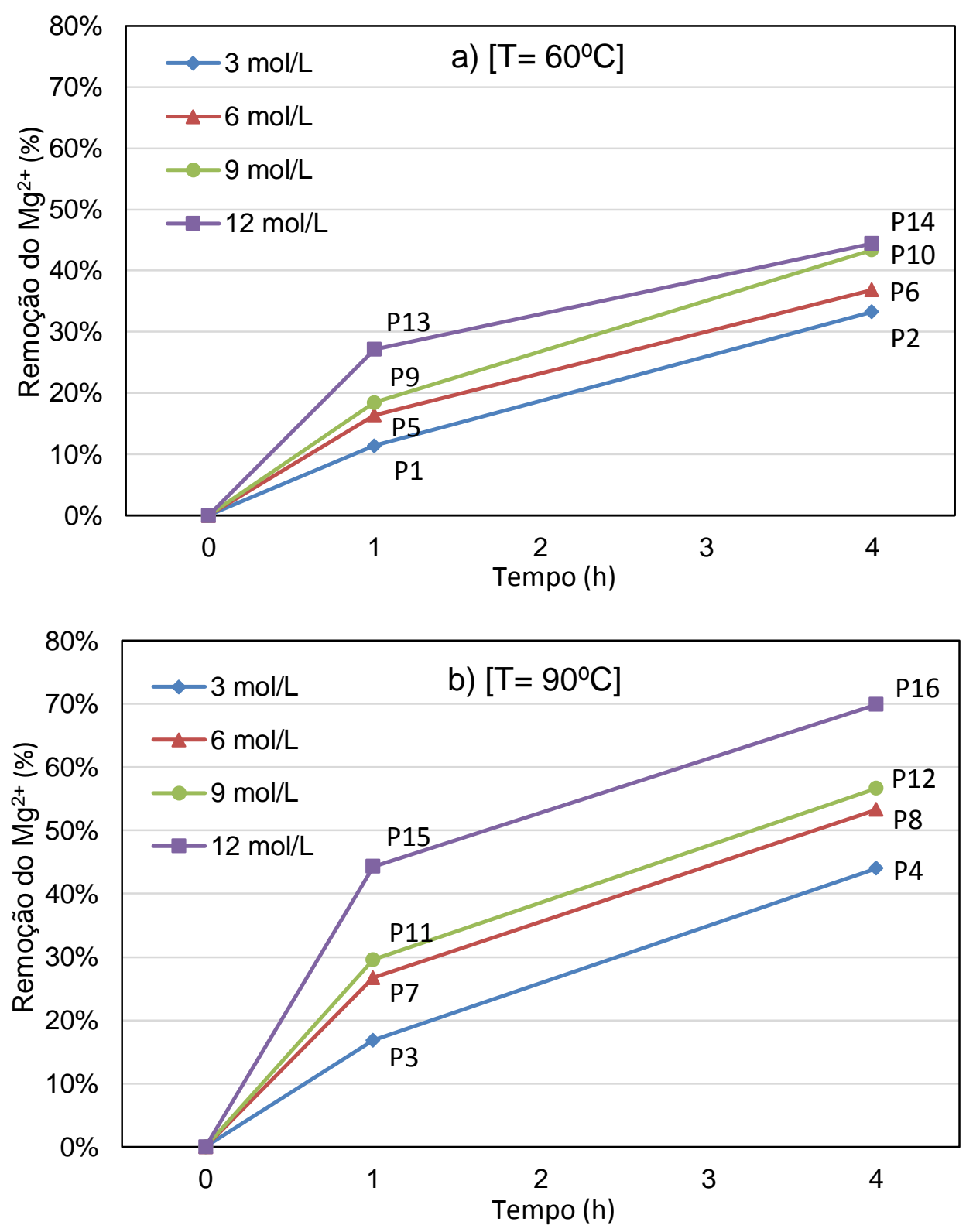

FIGURA 37 - Fração de cátions de magnésio $\left(\mathrm{Mg}^{2+}\right)$ removidos da paligorsquita purificada no processo de ativação em função do tempo e da concentração de ácido para cada temperatura a) $60^{\circ} \mathrm{C}$ e b) $90^{\circ} \mathrm{C}$. 
Na FIG.38 apresenta os valores normalizados (Fe, Mg, Al). Observa-se que para todas as amostras ativadas, a remoção dos cátions de ferro é superior à dos cátions de magnésio e de alumínio.

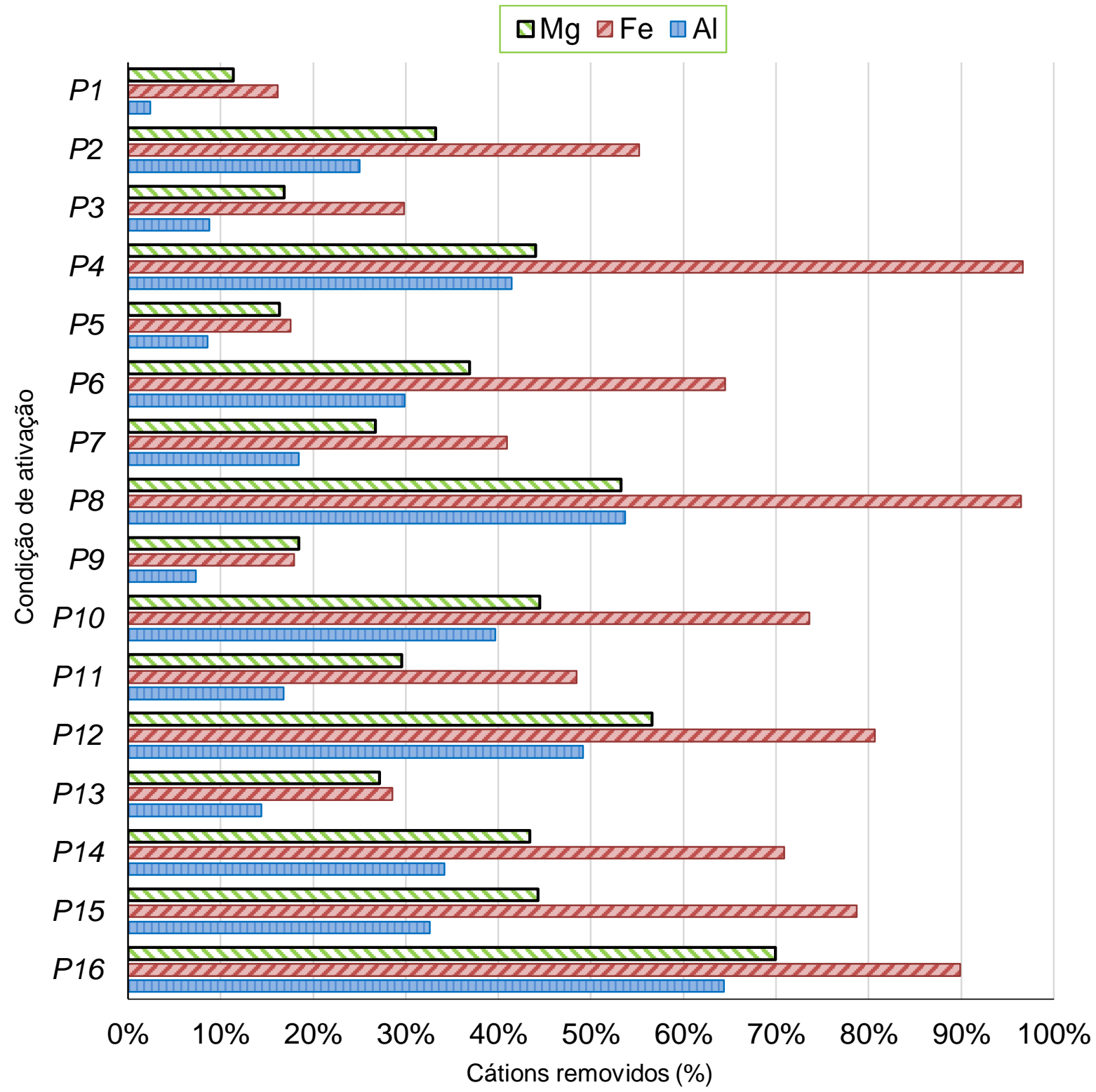

FIGURA 38 - Percentagens normalizados dos cátions de magnésio (Mg), ferro (Fe) e alumínio (Al) removidos para cada condição de ativação.

Com o objetivo de se aliar melhores rendimentos de extração com a preservação da integridade estrutural da paligorsquita, selecionou-se para esta verificação as melhores condições experimentais a cada intervalo de extração 
correspondente a $10 \%$ de $\mathrm{Mg}$ removido, considerando-se também as menores concentrações de Fe e Al removidas (FIG.38), como apresentado na TAB.23.

TABELA 23 - Melhores resultados para cada região escolhida de remoção dos cátions de magnésio e percentagens em massa lixiviado da paligorsquita.

\begin{tabular}{lccc}
\hline \multicolumn{1}{c}{ CONDIÇÃO } & $\begin{array}{c}\text { Região } \\
\text { escolhida }\end{array}$ & $\begin{array}{c}\text { Remoção de } \\
\text { Mg (\%) }\end{array}$ & $\begin{array}{c}\text { Mg Lixiviado* } \\
\text { (\%em massa) }\end{array}$ \\
\hline $\boldsymbol{P 9}\left(9 \mathrm{~mol} \cdot \mathrm{L}^{-1} / 60^{\circ} \mathrm{C} / \mathrm{h}\right.$ ) & $10-20 \%$ & $18,4 \%$ & $0,84 \%$ \\
$\boldsymbol{P 1 3}\left(12 \mathrm{~mol} \cdot \mathrm{L}^{-1} / 60^{\circ} \mathrm{C} / \mathrm{h}\right.$ ) & $20-30 \%$ & $27,2 \%$ & $1,25 \%$ \\
$\boldsymbol{P 2}\left(3 \mathrm{~mol} \cdot \mathrm{L}^{-1} / 60^{\circ} \mathrm{C} / 4 \mathrm{~h}\right)$ & $30-40 \%$ & $33,3 \%$ & $1,53 \%$ \\
$\boldsymbol{P 1 4}\left(12 \mathrm{~mol} \cdot \mathrm{L}^{-1} / 60^{\circ} \mathrm{C} / 4 \mathrm{~h}\right)$ & $40-50 \%$ & $43,4 \%$ & $1,99 \%$ \\
$\boldsymbol{P 1 2}\left(9 \mathrm{~mol} \cdot \mathrm{L}^{-1} / 90^{\circ} \mathrm{C} / 4 \mathrm{~h}\right)$ & $50-60 \%$ & $56,6 \%$ & $2,59 \%$ \\
$\boldsymbol{P 1 6}\left(12 \mathrm{~mol} \cdot \mathrm{L}^{-1} / 90^{\circ} \mathrm{C} / 4 \mathrm{~h}\right)$ & $60-70 \%$ & $69,9 \%$ & $3,20 \%$ \\
\hline
\end{tabular}

${ }^{*}$ Calculado a partir dos cátions de $\mathrm{Mg}^{2+}$ removidos em referência ao total de $\mathrm{Mg}^{2+}$ presente na amostra purificada $(4,58 \%$ massa $)$

Os difratogramas das amostras ativadas selecionadas estão apresentados na FIG.39, e quando comparados com a paligorsquita purificada (PP), de referência, observa-se que em todas as condições selecionadas a estrutura paligorsquita permanece. Entretanto algumas alterações relativas às intensidades e alargamentos dos picos dos espectros são observadas, acentuando-se com o aumento da concentração de $\mathrm{Mg}^{2+}$ removido.

Nos difratogramas apresentados na FIG.39 das amostras ativadas, pode-se observar que as amostras sob condições mais agressivas, identificadas como P14 $\left(\mathrm{CM}=12 \mathrm{~mol} \cdot \mathrm{L}-1, \mathrm{~T}=60^{\circ} \mathrm{C}\right.$ e $\mathrm{t}=4 \mathrm{~h}$.), $\mathrm{P} 12\left(\mathrm{CM}=9 \mathrm{~mol} \cdot \mathrm{L}-1, \mathrm{~T}=90^{\circ} \mathrm{C}\right.$ e $\left.\mathrm{t}=4 \mathrm{~h}\right)$, e g) $\mathrm{P} 16$ $\left(\mathrm{CM}=12 \mathrm{~mol} \cdot \mathrm{L}-1, \mathrm{~T}=90^{\circ} \mathrm{C}\right.$ e $\left.\mathrm{t}=4 \mathrm{~h}\right)$, apresentaram alargamento basal dos picos de paligorsquita, indicando a perda de cristalinidade da estrutura do argilomineral. 


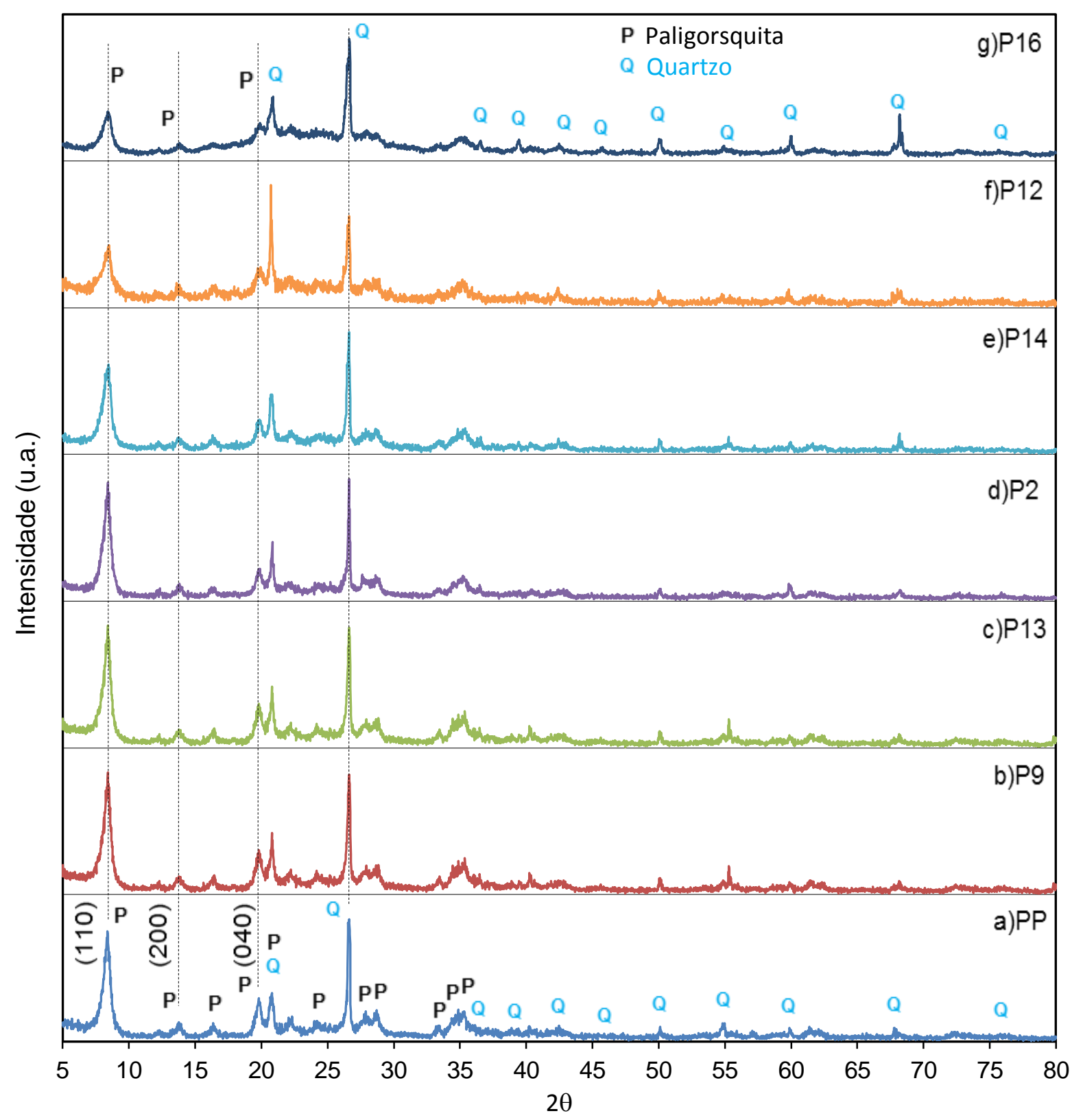

FIGURA 39 - Difratogramas de: a) amostra purificada (PP) e das amostras ativadas em função da remoção dos cátions de magnésio b) P9, c) P13, d) P2, e) P14, f) P12 e g) P16.

Simultaneamente, observou-se na FIG.39, que a sílica se manteve inalterada em quase todas as condições ensaiadas. Por este motivo, o pico mais intenso do quartzo (ICDD - 065 - 0466), foi utilizado como referência para avaliar comparativamente a redução de intensidade das principais difrações da paligorsquita. Este pico torna-se mais intenso com o aumento da intensidade das condições do ataque ácido e à medida que a concentração de magnésio removido 
aumenta, indicando que o ataque ácido ocorre somente na paligorsquita, tendo como efeito principal a diminuição da intensidade relativa dos picos correspondestes ao argilomineral, com a consequente diminuição do grau de cristalinidade. Esta diminuição do grau de cristalinidade foi observada para as condições P14, P12 e P16. Para demais condições de ataque ( $P 9, P 13$ e P2), nas quais a remoção dos cátions de magnésio foi inferior ao $40 \%$, não foi observado nem o alargamento, nem a perda de intensidade dos principais picos do argilomineral, e pelo tanto não apresentaram amorfização estrutural mantendo-se o grau de cristalinidade para estas condições.

Para fins comparativos, na TAB.24, são apresentados os principais picos de difração indexados para a paligorsquita, de acordo com o ICDD-031-0783, para a paligorsquita purificada $(P P)$ e para as amostras das condições de processo selecionadas.

TABELA 24 - Principais reflexões identificadas na ficha ICDD - 031 - 0783 e comparação das reflexões da paligorsquita purificada (PP) com as reflexões da paligorsquita das amostras ativadas (P9, P13, P2, P14, P12 e P16).

\begin{tabular}{ccccccc}
\hline Principais reflexões & \multicolumn{2}{c}{ (110) } & \multicolumn{2}{c}{ (200) } & \multicolumn{2}{c}{ (040) } \\
\hline ICDD-031-0783 & $2 \theta$ & $\mathrm{d}(\mathrm{nm})$ & $2 \theta$ & $\mathrm{d}(\mathrm{nm})$ & $2 \theta$ & $\mathrm{d}(\mathrm{nm})$ \\
AMOSTRA & $8,50^{\circ}$ & 1,040 & $13,92^{\circ}$ & 0,635 & $19,85^{\circ}$ & 0,447 \\
PP & & & & & & \\
P9 & $8,48^{\circ}$ & 1,041 & $13,82^{\circ}$ & 0,640 & $19,83^{\circ}$ & 0,447 \\
P13 & $8,38^{\circ}$ & 1,054 & $13,76^{\circ}$ & 0,643 & $19,80^{\circ}$ & 0,448 \\
P2 & $8,40^{\circ}$ & 1,051 & $13,76^{\circ}$ & 0,643 & $19,82^{\circ}$ & 0,447 \\
P14 & $8,48^{\circ}$ & 1,041 & $13,82^{\circ}$ & 0,640 & $19,84^{\circ}$ & 0,447 \\
P12 & $8,38^{\circ}$ & 1,055 & $13,78^{\circ}$ & 0,642 & $19,94^{\circ}$ & 0,445 \\
P16 & $8,30^{\circ}$ & 1,064 & $13,60^{\circ}$ & 0,650 & $19,96^{\circ}$ & 0,444 \\
& 8,34 & 1,059 & $13,68^{\circ}$ & 0,646 & $19,96^{\circ}$ & 0,444 \\
\hline
\end{tabular}

Observa-se nesta tabela que, para quase todas as condições do processo de ativação utilizadas, os espectros apresentam picos com um ligeiro deslocamento quando comparado com os picos do espectro de referência $(P P)$. Este deslocamento torna-se em geral, mais acentuado com o aumento da concentração de Mg removido da estrutura (P2 (18,4\%), P13 (27,2\%), P2 (33,3\%), P14 (43,4\%), 
P12 (56,6\%) e P16 (69,9\%). Como anteriormente verificado, este comportamento pode ser atribuído à redução de tamanho de cristalito ou amorfização de parte da estrutura. Entretanto, as condições de processo $P 2$, resultaram em um material análogo a paligorsquita de referência $(P P)$, como pode se verificar na TAB.24 os parâmetros de rede da estrutura foram todos preservados mesmo após ativação utilizando a temperatura de $60^{\circ} \mathrm{C}$, tempo de 4 horas e concentração $3 \mathrm{~mol} \cdot \mathrm{L}^{-1}$. Sendo este resultado bastante indicativo da eficiência do processo de ativação superficial e da integridade estrutural dos nanotubos de paligorsquita, essencial para sorção de espécies catiônicas em efluentes nucleares e posterior imobilização.

A condição $P 2$ é a condição de ensaio que apresentou maior integridade estrutural por não manifestar perda do grau de cristalinidade nem deslocamentos das principais reflexões após tratamento de ativação.

As mudanças observadas na estrutura da paligorsquita em função do tratamento ácido ficaram mais claramente evidenciadas por meio da espectroscopia de infravermelho.

Os espectros resultantes das amostras após tratamento de ativação são reportados nas FIG.40 e 43, que correspondem aos intervalos de energia de (4000 - $\left.3000 \mathrm{~cm}^{-1}\right)$ e $\left(1400-400 \mathrm{~cm}^{-1}\right)$, respectivamente. As intensidades e ombros registrados variam quando comparadas com os espectros da paligorsquita ativada, de acordo com os pesquisadores (FRINI-SRASRA e SRASRA, 2010; CHEN e WANG, 2009; MENDELOVICI, 1973; FROST e MENDELOVICI, 2006; CAI, XUE e POLYA, 2007; ESTEBAN-CUBILLO, 2007).

$\mathrm{Na}$ região de números de onda superiores $\left(4000-3000 \mathrm{~cm}^{-1}\right)$, FIG.40, registram-se as bandas correspondentes as ligações de metal com o grupo hidroxila $(\mathrm{M}-\mathrm{OH})$ e as bandas de vibração da agua $(\mathrm{OH}$-coordenada e $\mathrm{OH}$-zeolítica). Quando comparados os espectros entre as condições da paligorsquita purificada e ativada, observa-se que ocorre variações tanto nas intensidades como na localização das bandas registradas, assim como a ausência de algumas bandas identificadas na paligorsquita purificada.

A banda a $3697,7 \mathrm{~cm}^{-1}$ atribuída a vibração do estiramento do grupo $\mathrm{Mg}-\mathrm{OH}$ trioctaédrico, ( $F / G .35$, linha 20) está presente em quase todas as condições de ativação ensaiadas, exceto para as amostras $P 12$ e $P 16$, que também apresentaram alguma alteração nos resultados de difração de raios $X$ (FIG.39). Estes resultados fortemente caracterizam a ocorrência de alguma desestruturação, 
ainda que sutil, na paligorsquita quando submetida a processos de ativação em temperaturas superiores como $90^{\circ} \mathrm{C}$, em meio ácido de elevada concentração $(9 \mathrm{e}$ $12 \mathrm{~mol} / \mathrm{L}$ ) mesmo com tempos de ataque da ordem de 4 horas.

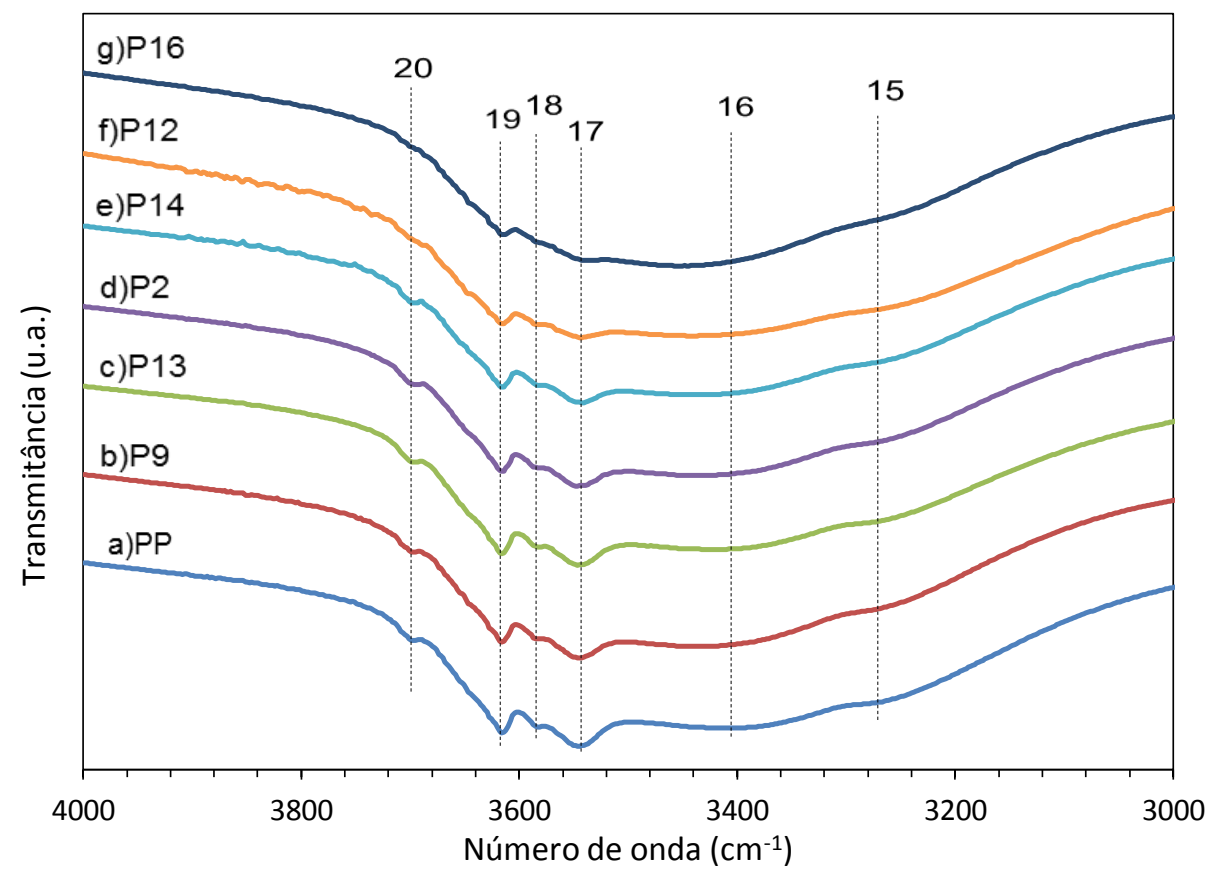

FIGURA 40 - Espectrogramas de número de onda altos: a) amostra purificada (PP) e das amostras ativadas em função da lixiviação dos cátions de magnésio b) P9, c) P13, d) P2, e) P14, f) P12 e g) P16.

CAI, XUE e POLYA (2007), estudando o processo de ativação ácida para diferentes paligorsquitas, observaram que na região de números de onda compreendidos entre $1400-400 \mathrm{~cm}^{-1}$ a banda atribuída a vibração de estiramento assimétrica do grupo $\mathrm{Si}-\mathrm{O}_{1}-\mathrm{Si}$, localizada em $1196 \mathrm{~cm}^{-1}$ desloca-se para um número de onda inferior. Esta ocorrência foi associada ao fato de que a dissolução por ataque ácido produz a quebra de parte das ligações $\mathrm{Si}_{-} \mathrm{O}_{1}$-Si localizadas nas bordas das camadas tetraédricas deste argilomineral. Este fato enfraquece o grupo $\mathrm{Si}_{-} \mathrm{O}_{1-}$ $\mathrm{Si}$, dando lugar a pequenas alterações no esqueleto de $\mathrm{SiO}$ da paligorsquita, no entanto mesmo para condições de ativação extremamente agressivas, e rompimento quase que total das ligações $\mathrm{Si}_{-} \mathrm{O}_{1}-\mathrm{Si}$, a estrutura básica, ou seja, o "esqueleto" se mantém, como foi verificado neste trabalho nos resultados de $D R X$.

Na região de números de onda inferiores, $\left(1400-400 \mathrm{~cm}^{-1}\right)$, para os espectros da paligorsquita ativada apresentados na FIG.41 observa-se que as condições $P 9$, 
P13 e $P 2$, onde o magnésio removido foi de $18,4,27,2$ e $33,3 \%$, respectivamente, mantiveram a totalidade das intensidades das bandas. Destacando as bandas definidas como características do esqueleto da paligorsquita (CAI, XUE e POLYA, 2007), localizadas a 1196, 1120, 1088, 1033 e $987 \mathrm{~cm}^{-1}$ (FIG. 43, linhas 12, 11, 10, 9 e 8, respetivamente). Entretanto para estas condições aprecia-se o indício de uma nova banda a $1220 \mathrm{~cm}^{-1}$ (FIG. 43, linha SA) caraterística de sílica amorfa (SA), localizada a $1200 \mathrm{~cm}^{-1}$ na literatura (MYRIAM, SUÁREZ-BARRIOS e MARTINPOZAS, 1998).

Para as condições $P 14, P 12$ e $P 16$, onde as concentrações de magnésio removidas foram superiores ao grupo anterior e iguais a 43,4, 56,6 e 69,9\% respectivamente, apresentaram os espectros na FIG.41 e, pode-se observar que ocorre o aumento das intensidades correspondentes a sílica amorfa (SA) cujas bandas de adsorção estão localizadas a 1220, 1090, 790 e $470 \mathrm{~cm}^{-1}$ (MYRIAM, SUÁREZ-BARRIOS e MARTIN-POZAS, 1998) o que indica a possível dissolução da sílica procedente da camada tetraédrica da paligorsquita.

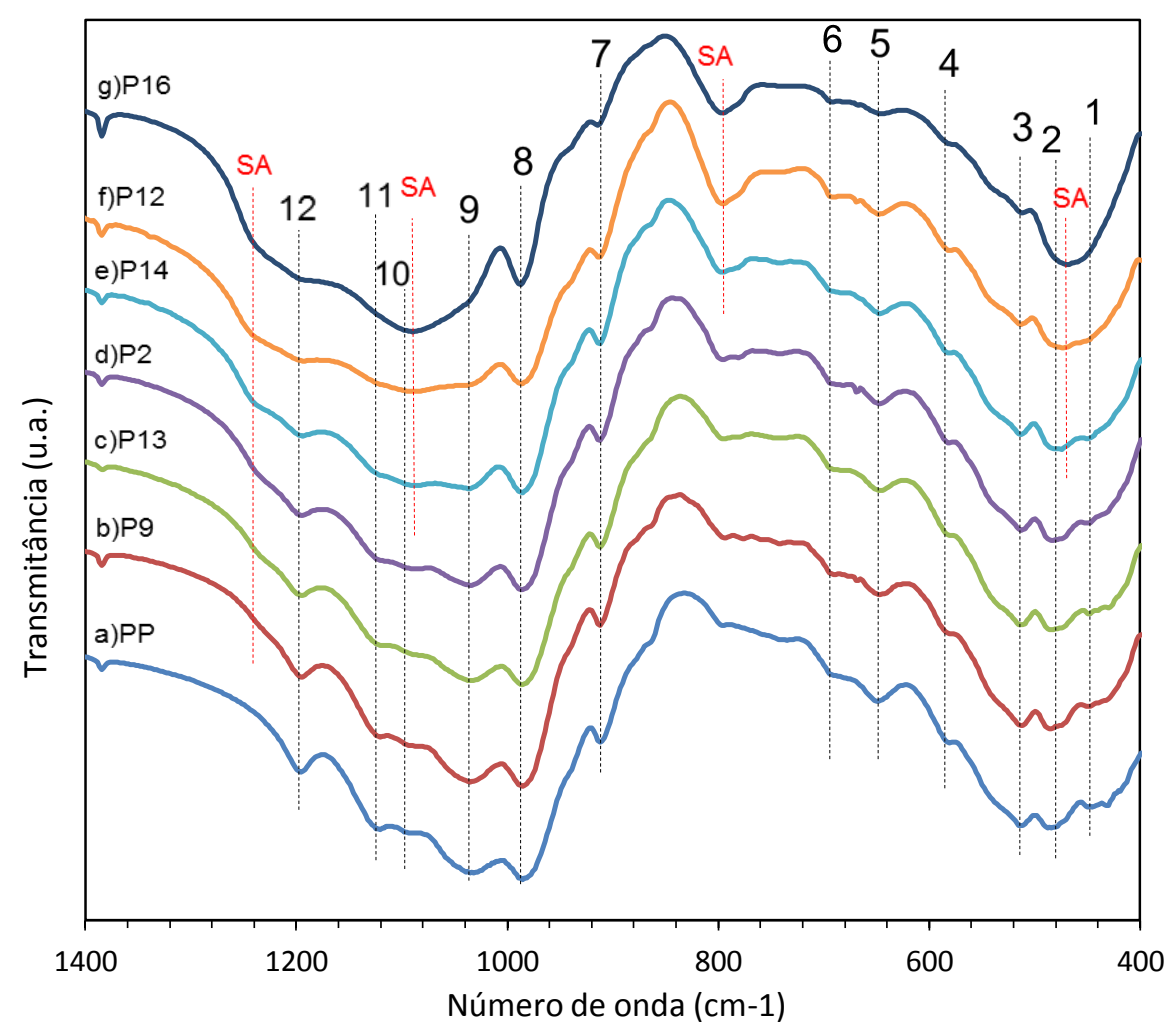

FIGURA 41 - Espectrogramas de baixo número de onda: a) amostra purificada (PP) e das amostras ativadas em função da lixiviação dos cátions de magnésio b) P9, c) P13, d) P2, e) P14, f) P12 e g) P16. 
Para estas mesmas condições as bandas localizadas em 1195, 1120, 1083, 1033, 987 e $478 \mathrm{~cm}^{-1}$ (FIG.41, linhas 12, 11, 10, 9, 8 e 2, respetivamente), diminuem a sua intensidade e deslocam-se ligeiramente para menores números de onda. Este fato foi atribuído por ESTEBAN-CUBILLO (2007), a um enfraquecimento das ligações Si-O-Si o que pode se associar com a existência da diminuição do grau de ordenação e consequente amorfização da estrutura, concordando com os difratogramas de raios $X$ para estas amostras.

Pode se afirmar para este estudo que o processo de ativação ácida nas condições $P 9, P 13$ e $P 2$ não apresentaram variações significativas dos espectros em relação a paligorsquita purificada. A condição $P 2$, mais uma vez assinala que nas condições utilizadas neste estudo foi a que apresentou valores limites de integridade estrutural ainda que a quantidade de magnésio removida não seja a máxima. Neste aspecto, para a incorporação e sorção de espécies catiônicas radioativas na estrutura, é necessário que a mesma apresente integridade nos canais/nanotubos e máxima concentração de sítios ativos para aumentar a reatividade. Ou seja, uma área de superfície específica elevada para favorecer esta incorporação.

O processo de ativação ácida pode modificar a área superficial específica do argilomineral em função das condições utilizadas como foi observado para os parâmetros de rede e estruturas vibracionais assinalados pela $D R X$ e IR-FT respectivamente.

Ao se verificar os potenciais de aplicação como sorventes de radionuclídeos presentes nos efluentes nucleares, é conveniente que a área de superfície específica seja otimizada ou maximizada. E neste estudo particular é interessante que a superfície externa dos nanotubos seja a máxima possível e que a superfície interna que corresponde aos microporos estruturais (nanotubos) sejam preservadas durante os tratamentos de ativação de superfície. Na literatura, a preocupação de manutenção estrutural é acompanhada mantendo-se os valores de área superficial específica próximos ou iguais ao material de partida (ESTEBANCUBILLO, PINA-ZAPARDIEL, et al., 2008). Também há estudos onde o valor maximizado de área superficial especifica visando a máxima concentração de sítios ativos é alcançado sem nenhuma preocupação de preservação estrutural (CHEN, ZHAO e WANG, 2007). Estas duas linhas de ação consideram apenas os valores 
de área superficial especifica desconsiderando a contribuição de cada tipo superfície, a externa e a dos microporos na formação de superfícies ativas.

Neste estudo, as análises de BET foram conduzidas acompanhando-se as variações de microporosidade.

$\mathrm{Na}$ FIG.42, aprecia-se para todas as isotermas que a quantidade de $\mathrm{N}_{2}$ adsorvido aumenta gradualmente com o incremento de pressão relativa quando $\mathrm{p} / \mathrm{p}_{\circ}<0,50$, na qual as líneas de adsorção/dessorção coincidem quase completamente indicando que a adsorção se produz em monocamada. Entretanto, um pequeno aumento na quantidade de $\mathrm{N}_{2}$ adsorvido é observado após a paligorsquita purificada ser ativada nas diferentes condições para toda a gama de pressões relativas

As isotermas das amostras ativadas e a purificada são similares e correspondem com o tipo IV na classificação IUPAC (IUPAC, 2014).

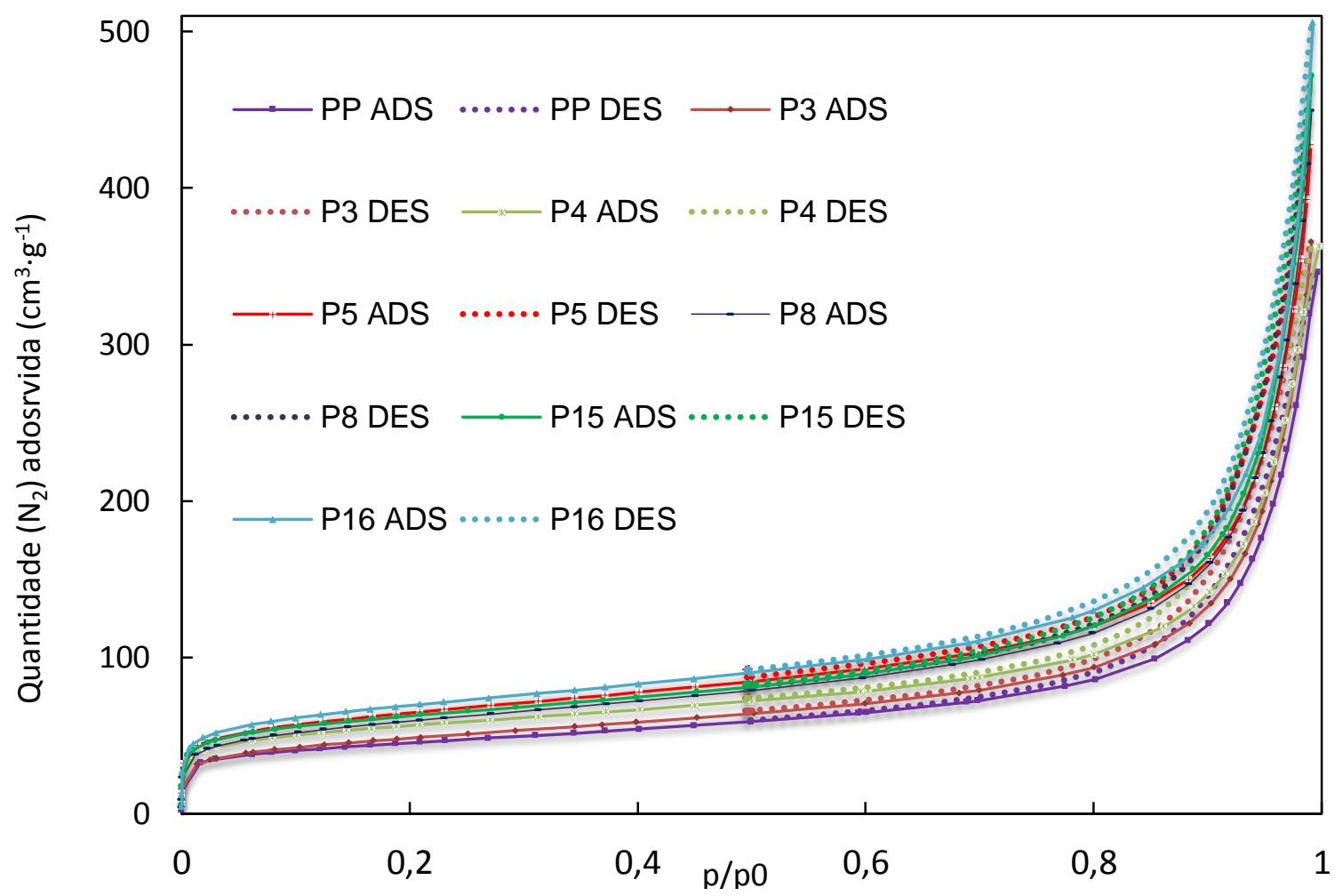

FIGURA 42 - Isotermas de adsorção-dessorção de $\mathrm{N}_{2}$ da paligorsquita purificada (PP) e das amostras ativadas (P9, P13, P2, P14, P12 e P16).

Por meio dos valores obtidos das isotermas de adsorção-dessorção de $\mathrm{N}_{2}$ foram calculados a área superficial específica $\left(S_{B E T}\right)$, os valores de área e volumem 
dos microporos e os parâmetro físico relacionados, das amostras ativadas nas diferentes condições (P9, P13, P2, P14, P12 e P16) e da purificada (PP), listadas na $T A B .25$.

TABELA 25 - Área superficial específica, área e volume dos microporos e parâmetros físicos relacionados da amostra purificada e as ativadas nas diferentes condições.

\begin{tabular}{cccccccc}
\hline AMOSTRA & $\begin{array}{c}\boldsymbol{S}_{\text {BET }} \\
\left(\mathrm{m}^{2} \cdot \mathrm{g}^{-1}\right)\end{array}$ & $\begin{array}{c}\boldsymbol{S}_{\text {ext }} \\
\left(\mathrm{m}^{2} \cdot \mathrm{g}^{-1}\right)\end{array}$ & $\begin{array}{c}\boldsymbol{S}_{\text {micro }} \\
\left(\mathrm{m}^{2} \cdot \mathrm{g}^{-1}\right)\end{array}$ & $\begin{array}{c}\boldsymbol{V}_{\text {TOTAL }} \\
\left(\mathrm{cm}^{3} \cdot \mathrm{g}^{-1}\right)\end{array}$ & $\begin{array}{c}\boldsymbol{V}_{\text {micro }} \\
\left(\mathrm{cm}^{3} \cdot \mathrm{g}^{-1}\right)\end{array}$ & $\begin{array}{c}\boldsymbol{V}_{\text {meso }} \\
\left(\mathrm{cm}^{3} \cdot \mathrm{g}^{-1}\right)\end{array}$ & $\begin{array}{c}\boldsymbol{d}_{\text {médio }} \\
(\mathrm{nm})\end{array}$ \\
\hline $\boldsymbol{P P}$ & 158,6 & 111,3 & 47,3 & 0,495 & 0,021 & 0,474 & 12,5 \\
$\boldsymbol{P 9}$ & 172,4 & 135,4 & 37,0 & 0,552 & 0,015 & 0,537 & 12,8 \\
$\boldsymbol{P 1 3}$ & 197,9 & 144,9 & 52,9 & 0,521 & 0,024 & 0,497 & 10,5 \\
$\boldsymbol{P 2}$ & 226,6 & 177,0 & 49,6 & 0,605 & 0,022 & 0,583 & 11,5 \\
$\boldsymbol{P 1 4}$ & 209,2 & 168,3 & 41,0 & 0,676 & 0,018 & 0,658 & 12,9 \\
$\boldsymbol{P 1 2}$ & 221,5 & 162,6 & 58,9 & 0,706 & 0,025 & 0,681 & 12,8 \\
$\boldsymbol{P 1 6}$ & 243,8 & 183,6 & 60,2 & 0,731 & 0,017 & 0,713 & 12,0 \\
\hline
\end{tabular}

Tendo como base os estudos reportados na literatura (ZHANG, WANG, et al., 2010; MYRIAM, SUÁREZ-BARRIOS e MARTIN-POZAS, 1998), pode se justificar a variação dos parâmetros de área e volumem do microporo, causada pela dissolução dos cátions presentes nas camadas octaédrica e tetraédrica em função da intensidade das condições de ativação utilizada.

O comportamento da área e de volume dos microporos na paligorsquita ativada, são representados na FIG.43 para as condições selecionadas.

De uma maneira geral, a área e volume dos microporos têm comportamentos similares para cada condição de ativação, e estes parâmetros podem contribuir ou não, no aumento da área superficial específica.

Na FIG.43.a, a área de superfície específica relativa aos microporos da paligorsquita purificada $(P P)$ aumenta após a ativação ácida, exceto para as condições $P 9$ e $P 14$ nas quais a mesma foi inferior a $10 \%$ do valor relativo à condição inicial, PP. Este comportamento pode ser indicativo da ocorrência de uma passivação dos canais ou um possível colapso ou "folding" estrutural. Para as amostras $P 12, P 13, P 16$ a área de microporos excedeu o valor de $10 \%$ em relação 
à condição $P P$ de referência. Este fato possivelmente indica que houve a dissolução excessiva dos cátions presentes nas camadas tetraédrica e octaédricas. Entretanto a condição $P 2$ apresentou um aumento na área de superfície específica dos microporos de apenas o 5\% em relação a referência $P P$. Como esta condição de processo tem apresentado um melhor comportamento até o momento, este valor pode ser indicativo de que há um fator limite de ativação e integridade estrutural dos nanotubos de paligorsquita.
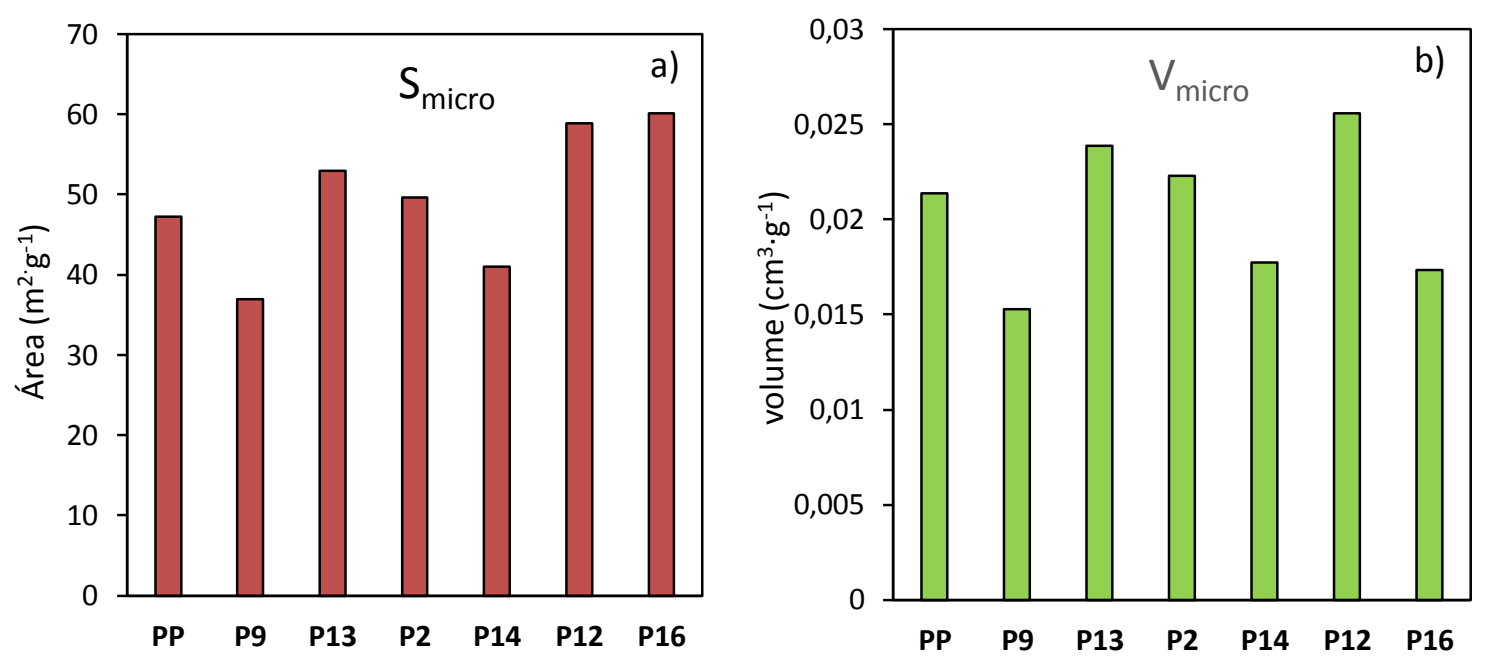

FIGURA 43 - a) Área calculada relativa aos microporos e b) Volume calculado dos microporos da amostra purificada (PP) e das amostras ativadas P9, P13, P2, P14, P12 e P16.

O volume determinado para os microporos relativo a $P P$ e demais condições de ativação, indicam comportamento similar as variações observadas na área dos microporos. A FIG.43.b, indica o aumento do volume dos microporos, excetuando nas amostras $P 9, P 14$ e $P 16$, para as quais o volume foi inferior a $10 \%$ em relação ao inicial PP. Estes comportamentos podem ser associados aos mesmos fenômenos destacados para as áreas dos microporos, ou seja, colapso ou modificação estrutural e, para as condições $P 12$ e $P 13$ os volumes de microporos aumentaram mais que $10 \%$ em relação à condição $P P$ também devido à possível dissolução da camada tetraédrica juntamente com a lixiviação excessiva dos cátions existentes na camada octaédrica. Para a amostra $P 2 \mathrm{o}$ valor do volume dos microporos foi inferior ao $5 \%$ do volume do microporo em relação à condição de partida PP. Apenas para a condição P16 na qual a estrutura apresenta maiores 
indícios de amorfização e perda do grau de cristalinidade estudada pelas técnicas $D R X$ e $F T$-IR (FIG.39, 42 e 43), é observado um comportamento distinto.

Deste modo, deve se procurar um compromisso entra a formação da maior quantidade de sítios ativos na forma de grupos silanol, é dizer, remoção da maior quantidade de cátions de $\mathrm{Mg}^{2+}$, sem que seja produzida modificação estrutural dos nanotubos ativados.

A área superficial específica da amostra de partida $P P$ igual a $158,6 \mathrm{~m}^{2} \cdot \mathrm{g}^{-1}$ aumentou para $226,6 \mathrm{~m}^{2} \cdot \mathrm{g}^{-1}$ na condição $P 2$.

A amostra $P 2$ apresentou os resultados mais favoráveis que as demais estudadas, em relação à integridade estrutural ( $D R X$ e $F T-I R)$, uma vez que, esta condição demonstrou menor variação nos parâmetros de área e volume dos microporos, com maior aumento da área superficial específica $(42,8 \%)$ removendo $33,3 \%$ dos cátions de magnésio

As morfologias analisadas por MEV, são apresentadas na FIG.44 para a paligorsquita a) purificada $(P P)$ e b) ativada $(P 2)$. Observa-se que ambas as amostras apresentam um aspecto fibrilar, de espessuras submicronicas que são preservadas mesmo após a ativação superficial na condição $P 2$.
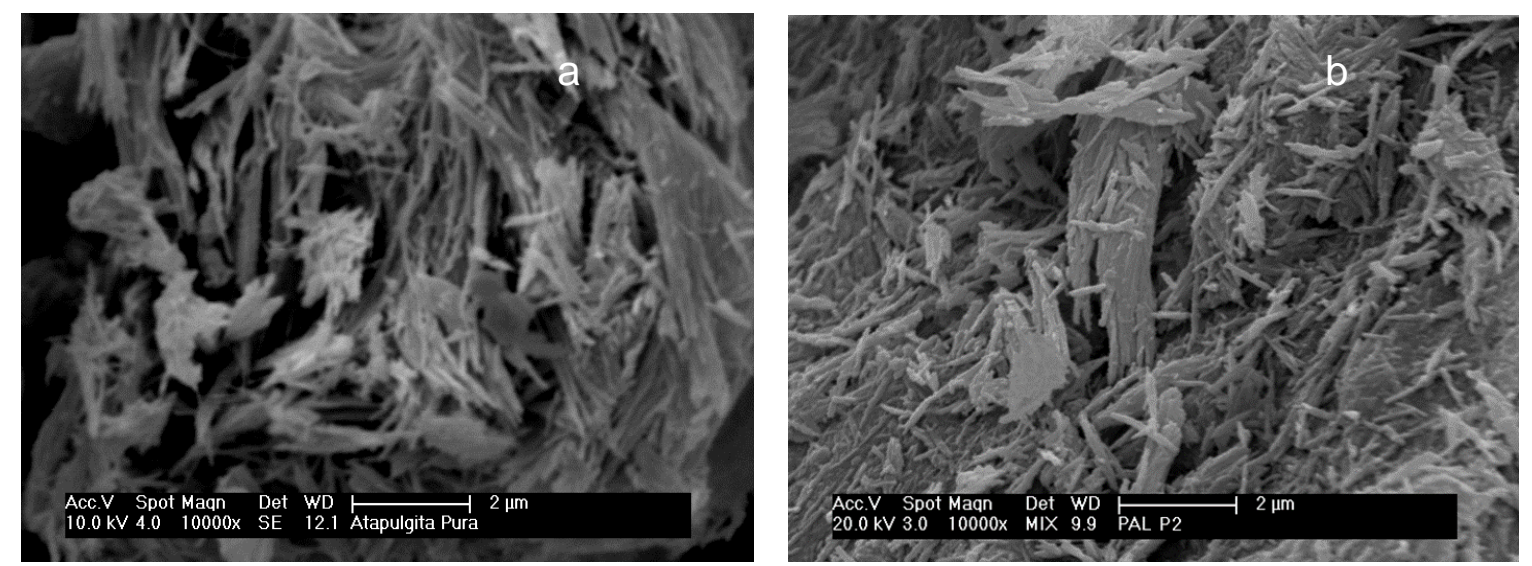

FIGURA 44 - Micrografias da paligorsquita purificada (PP) "a" e da paligorsquita ativada (P2) "b".

$\mathrm{Na}$ FIG.44 representam-se as micrografias obtidas por microscopia eletrônica de transmissão dos nanotubos da paligorsquita após o processo de ativação na condição $P 2$ (FIG.44.b), comparada com os da amostra de partida $P P$ (FIG.44.a). 
A análise da micrografia $(M E T)$ da amostra ativada na condição otimizada (P2) apresenta estrutura fibrilar de ração $\varnothing: L=0,051 \pm 0,013 \mathrm{~nm}$ aproximadamente (analisando 3 campos), análoga a amostra purificada $(P P)$, indicando que a estrutura dos nanotubos da paligorsquita é mantida após o processo de ativação ácida superficial na condição $P 2$.
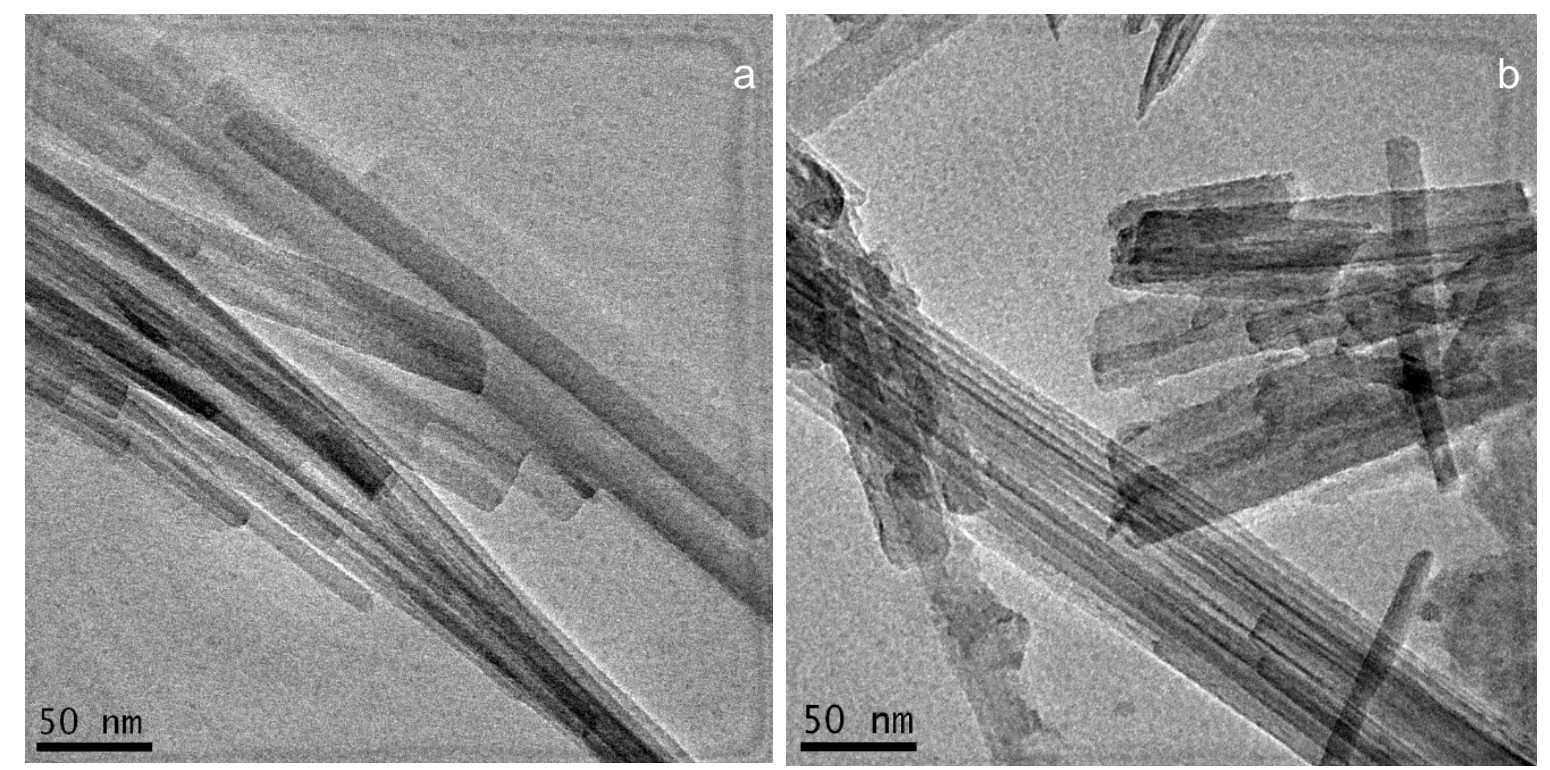

FIGURA 45 - Micrografias por Microscopia Eletrônica de Transmissão dos nanotubos naturais da paligorsquita a) purificada PP e b) ativada na condição P2.

As amostras obtidas na condição $P 2$ para os seguintes processos serão identificadas com o nome de paligorsquita ativada $(P A)$, como representado na TAB.26.

TABELA 26 - Condição otimizada de ativação superficial dos nanotubos naturais.

\begin{tabular}{|c|c|c|c|c|c|c|}
\hline CONDIÇÃO & Temperatura & Tempo & Concentração & $\% M g^{2+}$ & $M g L$ & ixiviado ${ }^{1}$ \\
\hline OTIMIZADA & $\left({ }^{\circ} \mathrm{C}\right)$ & (h) & $\operatorname{molar}\left(\mathrm{mol} \cdot \mathrm{L}^{-1}\right)$ & removido & $\left(\mathrm{mol} \cdot \mathrm{g}^{-1}\right)$ & (\%em massa) \\
\hline$P A$ & 60 & 4 & 3 & 33,3 & $6,30 \cdot 10^{-4}$ & 1,53 \\
\hline
\end{tabular}

${ }^{1}$ Calculado a partir dos cátions de $\mathrm{Mg}^{2+}$ removidos em referência ao total de $\mathrm{Mg}^{2+}$ presente na amostra purificada $(4,58 \%$ massa $)$ 


\subsection{Incorporação de radionuclídeos em nanotubos naturais ativados}

Conhecido e determinado o comportamento térmico do argilomineral e, fixada as condições de adequação superficial (PA), a etapa seguinte consiste na incorporação do radionuclídeos em nanotubos ativados.

Baseando-se nestes dados, os valores calculados previstos de inserção dos radionuclídeos na estrutura são os apresentados na TAB.27.

TABELA 27 - Concentrações de $\mathrm{Ni}^{2+}$ e $\mathrm{Sr}^{2+}$ previstas e calculadas para substituir o $\mathrm{Mg}^{2+}$ lixiviado, determinado na condição PA.

\begin{tabular}{ccccccc}
\hline CONDIÇÃO & \multicolumn{2}{c}{ Mg Lixiviado } & \multicolumn{2}{c}{$\mathbf{N i}^{2+}$} & \multicolumn{2}{c}{$\mathrm{Sr}^{2+}$} \\
OTIMIZADA & $\mathrm{mol} \cdot \mathrm{g}^{-1}$ & \%em massa & $\mathrm{mol} \cdot \mathrm{g}^{-1}$ & \%em massa & $\mathrm{mol} \cdot \mathrm{g}^{-1}$ & $\%$ em massa \\
\hline PA & $6,30 \cdot 10^{-4}$ & 1,53 & $6,30 \cdot 10^{-4}$ & 3,69 & $6,30 \cdot 10^{-4}$ & 5,52 \\
\hline
\end{tabular}

A incorporação destes cátions foi realizada de acordo com as condições descritas no item 4.3., adicionando-se $\mathrm{Ni}$ ou $\mathrm{Sr}$ em excesso para garantir que todos os sítios ativos fossem ocupados.

Após os ensaios de incorporação, o comportamento de sorção do níquel e do estrôncio são repostados nas FIG.46 e 47, respectivamente.

O comportamento de sorção de níquel pelos nanotubos, em função do tempo de ensaio ilustrado FIG.46, mostra a existência de várias regiões com diferentes cinéticas de sorção, o que pode estar associado à existência de diferentes mecanismos. Inicialmente $(0<\mathrm{t}<60 \mathrm{~min}$.), observa-se um comportamento de sorção de Ni a uma taxa relativamente alta até o valor de 32,89 $\pm 0,09 \mathrm{mg} / \mathrm{g}$ sorvida após a primeira hora do ensaio, correspondendo a uma velocidade de sorção de 0,548 $\mathrm{mg} \cdot \mathrm{g}^{-1} \cdot \mathrm{min}^{-1}$. Para tempos de ensaio maiores que 60 minutos, a curva de sorção muda de inclinação tendendo a um valor constante indicando uma possível mudança no mecanismo de sorção ou saturação da superfície. Para esta região de possível saturação o valor estimado de máxima capacidade de sorção $\mathrm{K}=36,89 \pm$ $0,09 \mathrm{mg} / \mathrm{g}$ para o tempo de 80 minutos foi análogo ao valor calculado em função da percentagem dos cátions de $\mathrm{Mg}$ removidos dos nanotubos naturais ativados (3,69\%massa), apresentado na TAB.27. Este resultado demonstra indubitavelmente a eficácia do processo de ativação de superfície, e o papel da 
remoção dos cátions de magnésio incorporando 100\% do valor calculado de níquel em tempos estimados de $80 \mathrm{~min}$. Ou seja, o processo de ativação ácida, torna os nanotubos de paligorsquita perfeitamente adequados para o processo de incorporação de radionuclídeos.

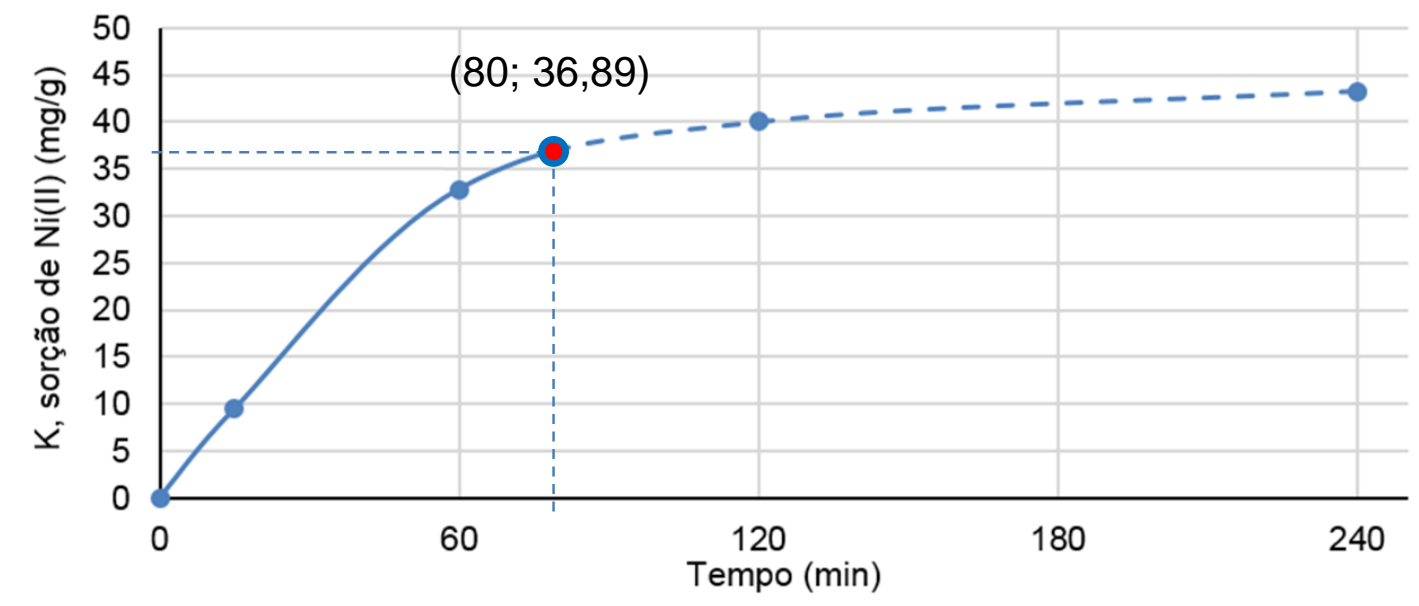

FIGURA 46 - Capacidade de sorção dos cátions de níquel na paligorsquita ativada em função do tempo (ICP).

Na FIG.47, o mesmo experimento foi realizado para os cátions de Sr, onde a máxima quantidade sorvida neste processo foi de $\mathrm{K}_{\mathrm{sr}}=3,33 \pm 0,02 \mathrm{mg} / \mathrm{g}$ $\left(0,375 \cdot 10^{-4} \mathrm{~mol} \cdot \mathrm{g}^{-1}\right)$ que equivale a $0,33 \%$ em massa após 24 horas de contato em suspensão. Este valor foi muito inferior ao valor calculado e esperado (5,52\%massa), apresentado na TAB.27. Deste modo, para o estrôncio, a sorção nas condições estudadas apresenta uma eficiência de apenas 5,97\%, ou seja, bem menor quando comparada com a do níquel (100\%).

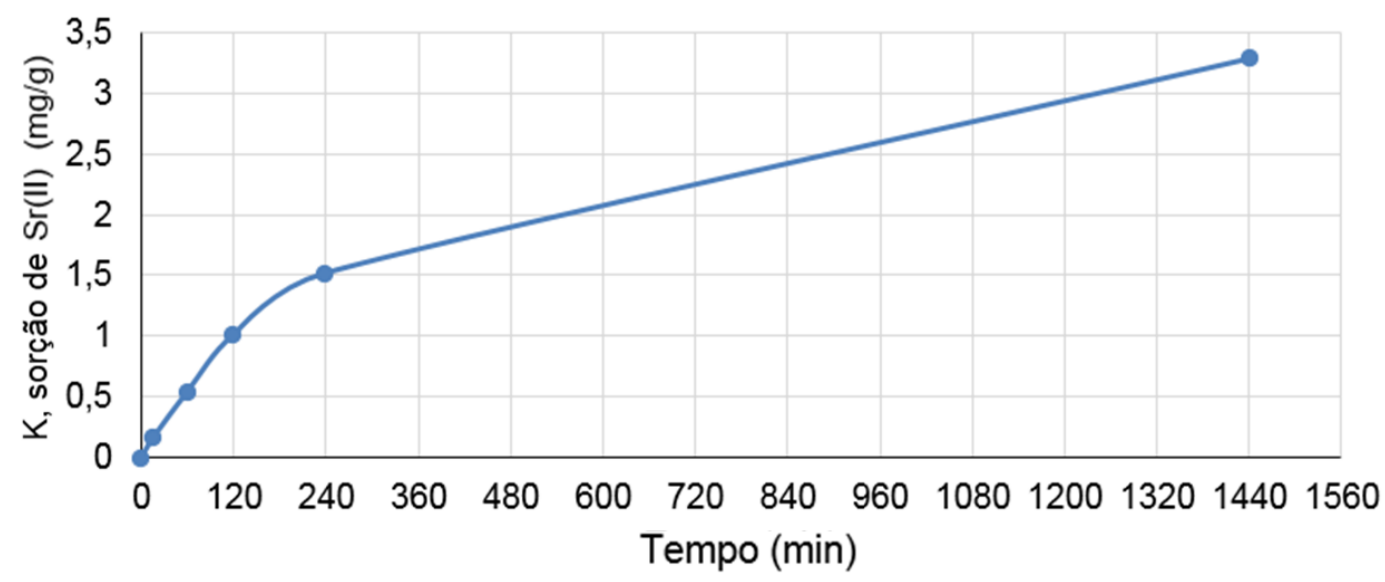

FIGURA 47 - Capacidade de sorção dos cátions de estrôncio na paligorsquita ativada em função do tempo (ICP). 
As amostras correspondentes aos nanotubos naturais ativados com $\mathrm{Ni}$ e $\mathrm{Sr}$ incorporados foram denominadas de PA-Ni e PA-Sr, respetivamente.

Para efeito apenas comparativo, o mesmo processo de incorporação de radionuclídeos foi realizado em condições similares para a paligorsquita sem ativar $(P P)$.

A TAB.28, apresenta os resultados obtidos por FRX-EDS, entre a paligorsquita sem ativar ( $P P-N i, P P-S r)$ e a ativada (PA-Ni, PA-Sr). A concentração em massa de níquel na amostra sem ativar ( $P P-N i)$, apresenta valores típicos correspondentes a sorção de níquel observados na literatura (FAN, SHAO, et al., 2009; CHEN, GAU e LU, 2011; SHEIKHHOSSEINI, SHIRVANI, et al., 2014).

Estes resultados demonstram que o Processo de Ativação Superficial dos nanotubos naturais aumenta significativamente a capacidade de sorção destes argilominerais por cátions tais como o níquel. Entretanto, no caso do estrôncio, comparando-se ambas as condições, PP e PA, se observou que a ativação ácida não promoveu um aumento na sorção deste elemento. Como o rendimento de sorção do estrôncio foi muito inferior ao esperado, as etapas posteriores deste estudo serão realizadas apenas para o níquel.

TABELA 28 - Fluorescência de Raios X por EDS em óxidos das amostras de paligorsquita ativada com metal (PA-Ni e PA-Sr) e das amostras sem ativar (PPNi e PP-Sr).

\begin{tabular}{cccccccc}
\hline & \multicolumn{7}{c}{ Composição (\% em massa) } \\
\hline AMOSTRA & $\mathrm{SiO}_{2}$ & $\mathrm{Al}_{2} \mathrm{O}_{3}$ & $\mathrm{MgO}$ & $\mathrm{Fe}_{2} \mathrm{O}_{3}$ & NiO & SrO & Outros \\
\hline PA-Ni & 63,8 & 14,8 & 6,3 & 7,0 & 5,8 & $N D$ & 2,7 \\
PP-Ni & 65,6 & 15,6 & 8,2 & 7,2 & 0,6 & $N D$ & 2,8 \\
PA-Sr & 70,6 & 14,3 & 7,1 & 5,4 & $N D$ & 0,1 & 2,5 \\
PP-Sr & 65,7 & 15,7 & 8,8 & 7,1 & $N D$ & 0,1 & 2,6
\end{tabular}

${ }^{\star}$ Percentagem em massa sem avaliar a Perda ao Fogo a $900^{\circ} \mathrm{C}$. $N D=$ Não detectado.

O colapso por tratamento térmico dos nanotubos pode contribuir para a imobilização dos radionuclídeos na estrutura dos nanotubos naturais com níquel. 0 colapso estrutural dos nanotubos foi estudado submetendo as amostras PA-Ninas condições de temperatura e tempo otimizadas $\left(550^{\circ} \mathrm{C} / 3\right.$ horas) ilustradas na TAB.20. Após os tratamentos térmicos as amostras foram caracterizadas por 
difração de raios $\mathrm{X}$, microscopia eletrônica de transmissão $(M E T)$ e microanálise (MET-EDS).

A FIG.48 apresenta os difratogramas resultantes das amostras de paligorsquita sob as várias condições de preparação onde não se observam alterações estruturais significativas devido a remoção dos cátions de magnésio e a posterior incorporação de níquel. Comparando-se os espectros entre a amostra $P P($ a) e a condição $P A-N i$ (b) e $P A-N i 550$ (c), é clara a ausência dos picos relativos ao níquel, indicando que possivelmente este tenha entrado na estrutura nanotubular da paligorsquita. Entretanto, analisando-se o espectro das amostras após o tratamento térmico a $550^{\circ} \mathrm{C} / 3 \mathrm{~h}$ (FIG.48.c), observa-se como esperado, que ocorre uma variação na estrutura atribuída principalmente ao processo de colapso estrutural $\left(P_{1}-P_{5}\right)$ como estudado e observado no item 5.3. Estes resultados são discutidos e analisados considerando os limites de detecção da técnica de análise.

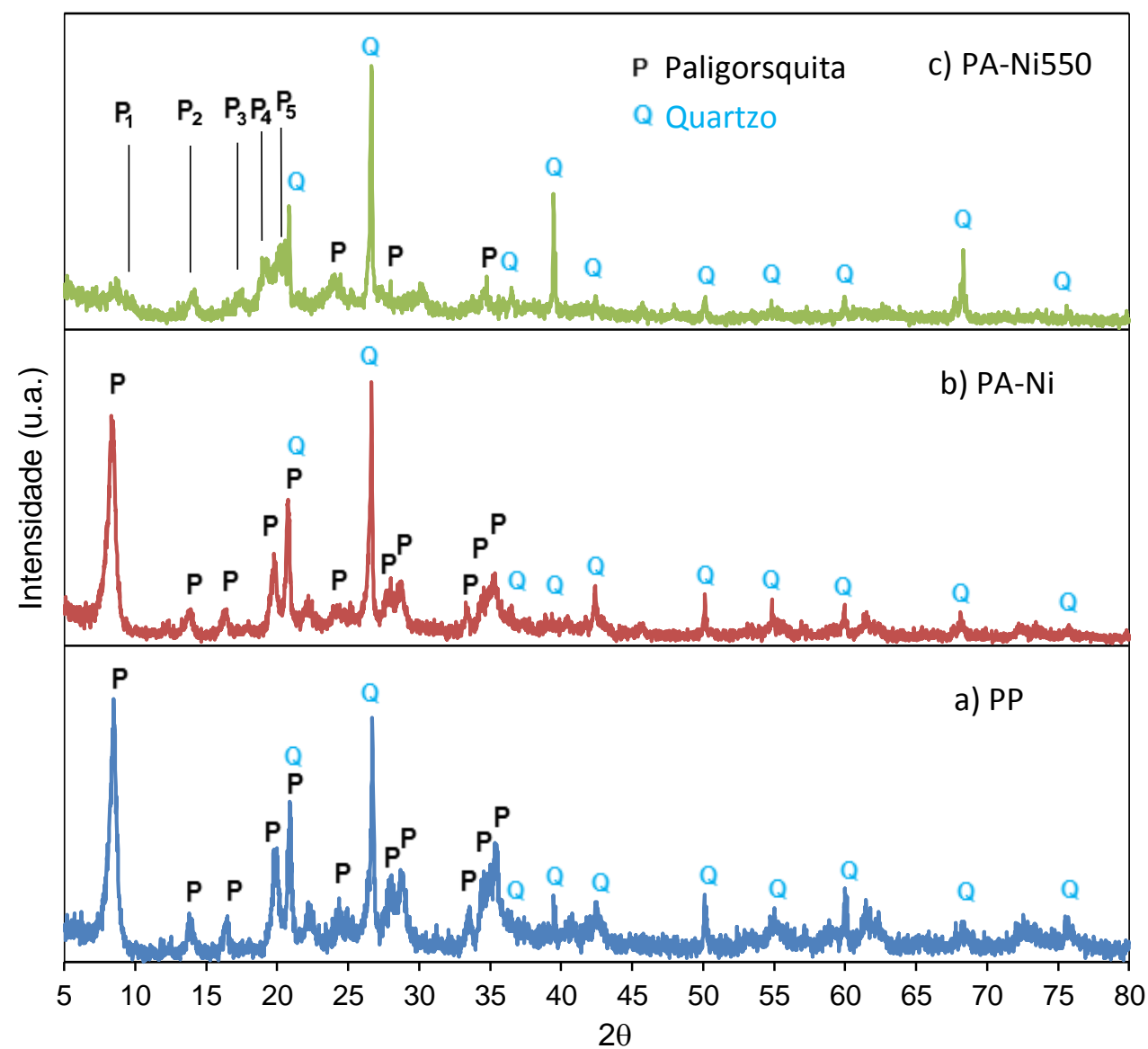

FIGURA 48 - Difratograma das amostras de paligorsquita a) purificada (PP), b) com níquel (PA-Ni) e c) com níquel tratada a 550드 (PNi-550) 
Na FIG.49, são apresentadas as micrografias e o microanálise, obtidas por MET-EDS a partir dos nanotubos PA-Ni. Na FIG.49.a, observa-se que a morfologia fibrilar dos nanotubos ativados não foi modificada após a incorporação de niquel. Nas micrografias apresentadas nas FIG.49.a,b, e c não se observaram apresença de níquel, nos vários campos e aumentos estudados. Entretanto, as análises de EDS realizadas no campo da FIG.49.c, identificam os picos caracterísiticos deste elemento, FIG.49.d. Estes resultados podem indicar que a incorporação do niquel foi no interior dos nanotubos naturais ativados.
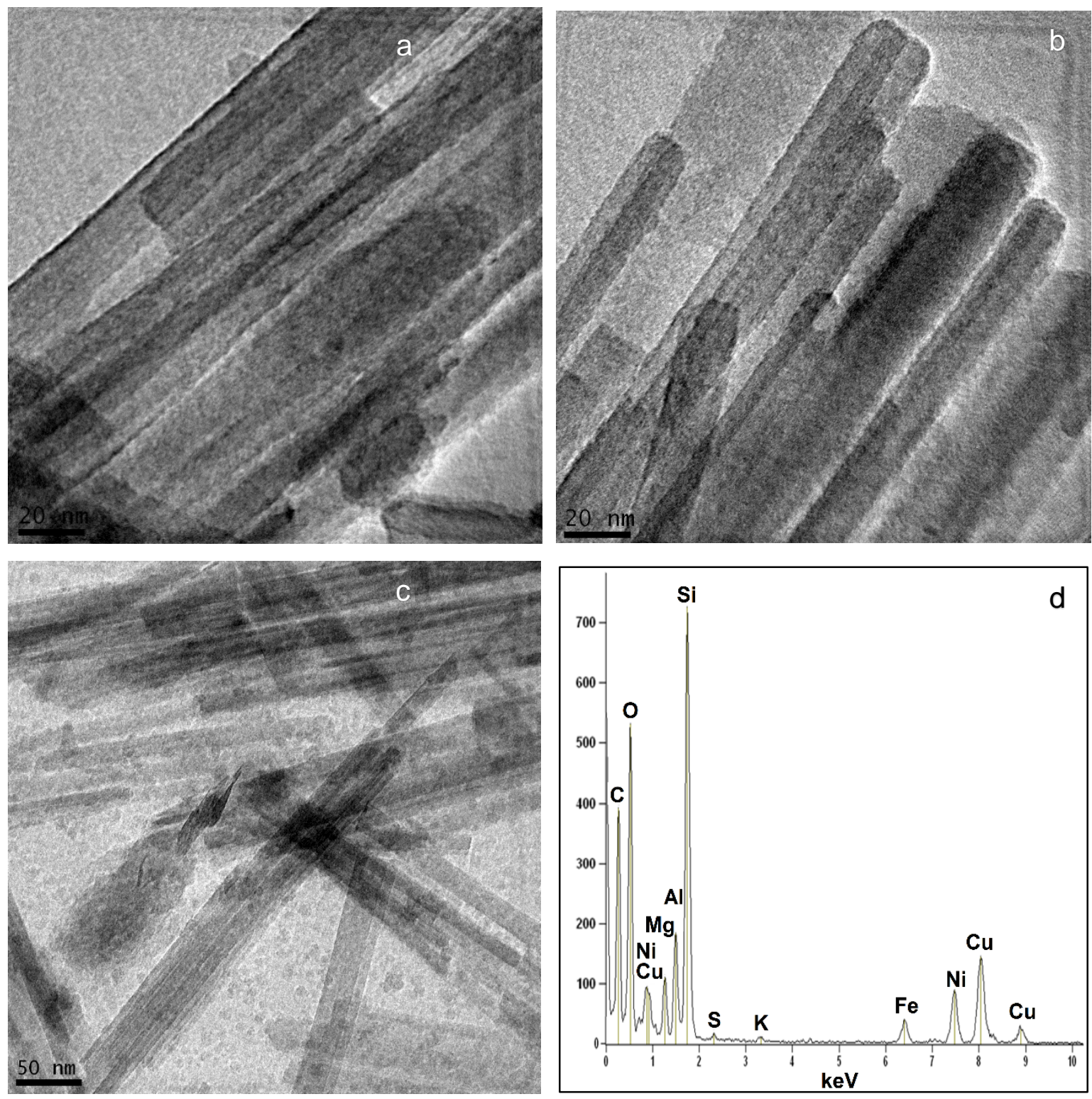

FIGURA 49 - MET com EDS da paligorsquita ativada com níquel (PNi) 
As amostras $P A-N i$, submetidas a tratamentos térmicos de colapso estrutural

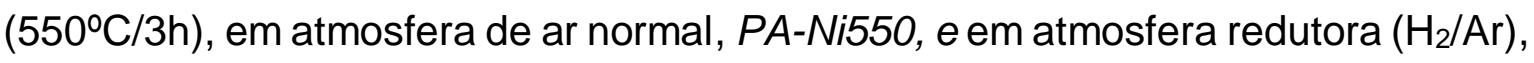
PA-Ni550r, foram analisadas por MET e as micrografias resultantes são apresentadas na FIG.50. O tratamento em atmosfera redutora foi realizado apenas para revelar a presença de $\mathrm{Ni}$ na estrutura. Na FIG.50.a, a micrografica correspondente a amostra PA-Ni550 que não apresenta nanopartículas de níquel precipitadas sobre a sua superficie e nem aglomerados nanométricos, no entanto quando o mesmo tratamento térmico foi realizado em atmosfera redutora, para a amostra PA-Ni550r, correspondente à micrografia da FIG.50.b, os nanotubos apresentaram nanoparticulas ou aglomerados nanometricos, que possivelmente correspondam ao niquel.
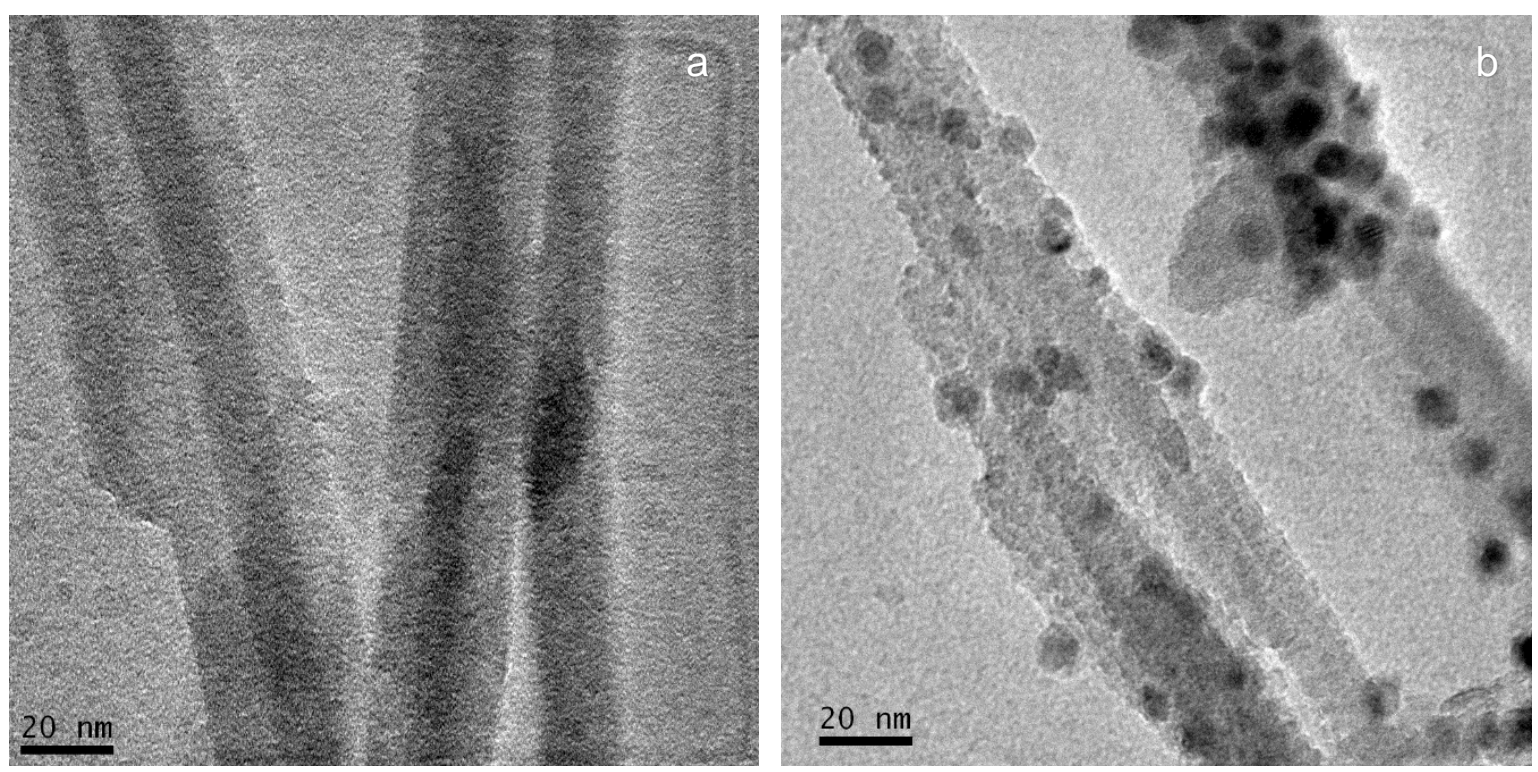

FIGURA 50 - Micrografias por MET da amostra PA-Ni tratada termicamente em

a) atmosfera ao Ar e b) atmosfera redutora, nas condições otimizadas

$\mathrm{Na}$ FIG.51, são apresentadas as micrografias e as microanálises (METEDS), obtidas a partir dos nanotubos PA-Ni550r. A análise qualitativa das nanopartículas ou aglomerados nanométricos de níquel foi realisada no campo apresentado pela FIG.51.a. Na FIG.51.b, ilustram-se as micronálises correspondentes aos pontos 1 e 2, localizados nas regiões dos nanotubos com e sem presença de nanopartícula, respectivamente. Estes resultados indicam que as nanopartículas ou algomerados nanométricos observados correspondem ao níquel 
incorporado, o qual foi reduzido após tratamento térmico em atmosfera $\left(\mathrm{H}_{2} / \mathrm{Ar}\right)$, como esperado.

As micrografias (MET) apresentadas nas FIG.51.ce $d$. mostram que o níquel possui uma distribuição homogênea ao longo dos nanotubos e baixa variação do tamanho médio das nanopartículas ou aglomerados nanométricos de $\mathrm{Ni}$.

Estas micrografias e microanálises obtidas por MET-EDS da amostra PA-Ni550r confirmam visual e qualitativamente a incorporação do niquel nos nanotubos natuarais ativados da paligorsquita.
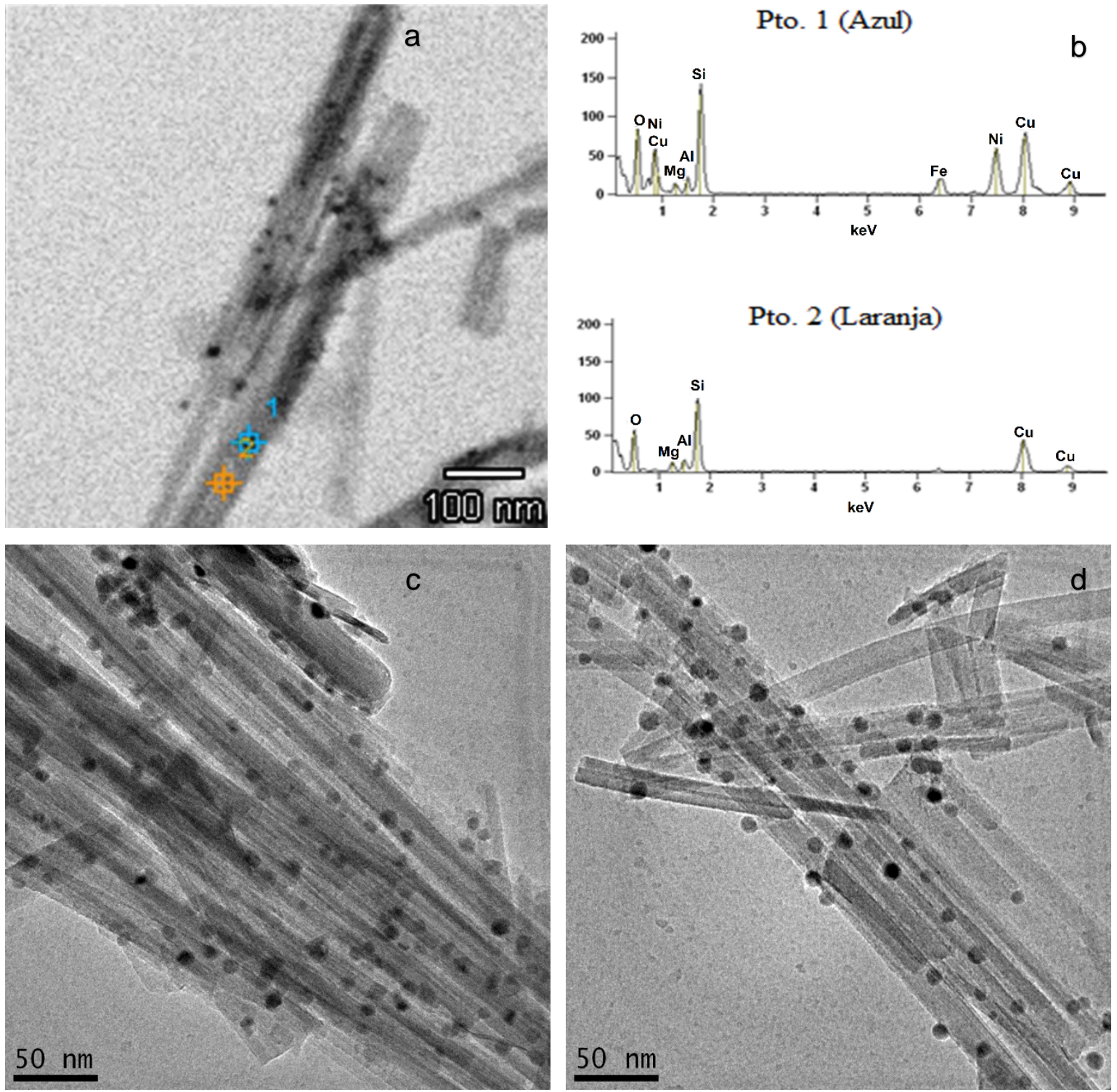

FIGURA 51 - Micrografias com MET e microanálise (EDS) dos nanotubos ativados com níquel incorporado tratada termicamente em atmosfera redutora $\left(\mathrm{H}_{2} / \mathrm{Ar}\right)$ (PA-Ni550r). 


\section{CONCLUSÕES}

Os nanotubos naturais de paligorsquita nacional foram desenvolvidos, modificados e adequados para incorporação eficiente de radionuclídeos no tratamento de efluentes nucleares.

O processo de ativação ácida se mostrou eficiente, removendo seletivamente $33 \%$ do total dos cátions de magnésio da estrutura dos nanotubos, que corresponde a 1,53\% em massa de $\mathrm{Mg}$ lixiviado da paligorsquita sem modificação estrutural e aumentando a área superficial específica em $42,8 \%$, em relação ao valor de referência.

Os nanotubos ativados com uma capacidade de sorção máxima estimada de $\mathrm{K}=36,89 \mathrm{mg} \cdot \mathrm{g}^{-1} \mathrm{em} 80 \mathrm{~min}$, incorporaram $3,69 \%$ de níquel, concentração equivalente à do magnésio removido da estrutura, confirmando a eficiência do processo de ativação superficial na sorção de espécies similares ao níquel. A condição PA, otimizada foi fundamental para aumentar a capacidade de sorção do níquel nos nanotubos ativados da paligorsquita.

O colapso estrutural dos nanotubos contendo níquel foi obtido na temperatura de $550^{\circ} \mathrm{C}$ por 3 horas em atmosfera normal. As análises de difração de raios $X$ das amostras tratadas e colapsadas confirmam a incorporação de níquel na estrutura dos nanotubos naturais de paligorsquita.

Os nanotubos naturais ativados da paligorsquita são um material adequado para remoção eficiente de radionuclídeos, aumento da concentração destes em fase sólida e posterior consolidação para a redução de volume dos efluentes nucleares. 
AGUIAR, M.; NOVAES, A.; GUARINO, A. Remoção de metais pesados de efluentes industriais por aluminosilicatos. Quimica Nova, 25, n. 6b, 2002. 1145-1154.

ALLARD, T.; BALAN, E.; CALAS, G. Radiation Effects on Clay Minerals. In: BERGAYA, F.; LEGACY, E. Handbook of Clay Science. Oxford: Elsavier, v. 5A, 2013. p. 127-138.

ALLEN, T. Particle Size Measurement. 5. ed. [S.I.]: Springer Netherlands, v. 7, 1997.

ALLEONI, L.; CAMARGO, O.; CASAGRANDE, J.; SOARES, M. Química dos solos altamente intemperizados.. In: MELO, V.; ALLEONI, L. Química e mineralogia do solo. Viçosa, MG: Sociedade Brasileira de Ciência do Solo, v. 2, 2009. p. 381-447.

ALMEIDA, S. L. M.; CHAVES, A. P. Usos Industriais da Atapulgita de Gaudalupe-PI. Universidade de São Paulo - Departamento de Engenharia de Minas. São Paulo, p. 16. 1995.

ALVAREZ-AYUSO, E.; GARCIA-SANCHEZ, A. Palygorskite as a feasible amendment to stabilize heavy metal polluted soils. Environmental Pollution, 2003. 337-344.

AMPHLETT, C. B.; WARREN, D. T. The temperature distribution in a heated clay block and its application to the problem of fission product disposal. Atomic Energy Research Establishment, 1956. 1-6.

ARSHADI, M.; AMIRI, M.; MOUSAVI, S. Kinetic, equilibrium and thermodynamic investigations of $\mathrm{Ni}(\mathrm{II}), \mathrm{Cd}(\mathrm{II}), \mathrm{Cu}(\mathrm{II})$ and $\mathrm{Co}(\mathrm{II})$ adsorption on barley straw ash. Water Resources and Industry, 6 , 2014. 1-17.

BAILEY, S. W. Structure of layer silicates. In: BAILEY, S. W. Crystal Structures of Clay Minerals and Their X-ray Identification. London: Mineralogical Society, 1980. p. 1-123.

BANERJEE, C; DUDWADKAR, N; TRIPATHI, S. C.; GANDHI, P. M.; GROVER, V.; KAUSHIK, C. P.; TYAG, A. K.. Nano-cerium vanadate: A novel inorganic ion exchanger for removal of americium and uranium from simulated aqueous nuclear waste. Journal of Hazardous Materials, 280, 2014. 63-70.

BASCETIN, E.; HAZNEDAROGLU, H.; ERKOL, Y. The adsorption behavior of cesium on silica gel.. Applied Radiation and Isotopes, 59, 2003. 67-76.

BERGAYA, F.; LAGALY, G. Purification of Natural Clays. In: BERGAYAA, F.; LAGALY, G. Handbook of Clay Science. Developments in Clay Science v. 2. ed [S.I.]: Elsavier Ltd, v. 1, 2013. p. 215.

BERGAYA, F.; LAGALY, G.; VAYER, M. Cation and Anion Exchange. In: BERGAYA, F.; LAGALY, G. Handbook of clay science. Developments in Clay Science. v. 2.. ed. [S.I.]: Elsevier Ltd, v. 1, 2013. p. 333-359. 
BeRGAYA, F.; THENG, B.; LAGALY, G. Handbook of Clay Science. Developments in Clay Science. [S.I.]: [s.n.], v. 1, 2006.

BOSTELMANN, E. Avaliação da concentração de metais em amostras de sedimento do reservatório Billings, braço Rio Grande, São Paulo, Brasil. Dissertação (Mestrado) - Instituto de Pesquisas Energéticas e Nucleares, Universidade de São Paulo. São Paulo. 2006.

BOUDRICHE, L.; CALVET, R.; HAMDI, B.; BALARD, H.. Surface properties evolution of attapulgite by IGC analysis as a function of thermal treatment. Colloids and Surfaces A: Physicochem. Eng. Aspects , 399, 2012. 1- 10.

BOUDRICHE, L.; CALVE, R.; CHAMAYOU, A, HAMDI, B.; BALARD, H.. Removal of lead(II) from aqueous solution using modified palygorskite, contribution of inverse gas chromatography. $\boldsymbol{J}$ Chromatography Acta, 1408, 2015. 207-216.

BRADLEY, W. I. Structure of attapulgite. American Mineralogy, 25, 1940. 405-410.

BRANDÃO, A. Paligorsquita como adsorvente para íons de metais de transição-estudos cinéticos e do equilíbrio. Tese de doutorado. Universidade Federal de Paraíba. [S.I.]. 2011.

BROOKHAVEN INSTRUMENTS CORPORATION. Instrunction Manual for BI-MAS-Multi angle Sizing Option on the ZetaPlus. [S.I.]: [s.n.], 1995.

BRUNAUER, S.; EMMETT, P.; TELLER, E. Adsorption of fases in multimolecular layers. Journal American Chemical Society, 90, 1938. 309-319.

CAI, Y.; XUE, J.; POLYA, D. A Fourier transform infrared spectroscopic study of Mg-rich, Mg-poor and acid leached palygorskites. Spectrochimica Acta , 66, 2007. 282-288.

CASES, J.; BEREND, I.; FRANÇOIS, M.; URIOT, J.; MICHOT, L.; THOMAS, F. Mechanism of adsorption and desorption of water vapor by homoionic montmorillonite; 3 , The Mg (super 2+), Ca (super 2+), and Ba (super 3+) exchange. Clay and Clay Minerals, 45, n. 1, 1997. 8-22.

CHEN, L; GAO, B.; LU, G. Sorption study of radionickel on attapulgite as a function of $\mathrm{Ph}$, ion strength and temperature. J Radioanal Nucl Chem, 288, 2011. 851-858.

CHEN, H.; ZHAO, Y.; WANG, A. Removal of $\mathrm{Cu}(\mathrm{II})$ from aqueous solution by adsorption onto acidactivated palygorskite. Journal of Hazardous Materials, 149, n. 2, 2007. 346-354.

CHENG, H.; YANG, J.; FROST, R.; WU., Z.. infrared transmission and emission spectroscopic study of selected Chinese palygorskites. Spectrochimica acta, 83, 2011. 518-524.

CHENG, H.; YANG, J.; FROST, R. Thermogravimetric analysis-massspectrometry (TG-MS) of selected Chinese palygorskites- implications for structural water. Thermochimica Acta, 512, 2011. 202-207.

CHISHOLM, J. E. Powder-difraction patterns and structural models for palygorskite. Canadian Mineralogist, 30, 1992. 61-73.

CHRIST, C.; HATHAWAY, J.; HOSTETLER, P.; SHEPARD, A.. Palygorskite new X-ray data. Americam Mineralogy, 54, 1969. 198-205.

CLIFFORD, D. A. Ion exchange and inorganic adsorption. In: ASSOCIATION, A. W. W. Water quality and treatment: a handbook of community water supplies. [S.I.]: McGraw-Hill, v. 1, 1999. Cap. 9, p. 1-91.

CNEN. Glosario de Segurança Nuclear. Comissão Nacional de Energia Nuclear - CNEN. 2015. 
CNEN. Gestãode rejeitos radioativos de baixo e médio nivel de radiação. CNEN-NN-8.01. [S.I.]. 2014.

CORMA, A.; MIFSUD, A.; SANZ, E. Influence of the chemical composition and textural characteristics of palygorskite on the acid leaching of octahedral cations. Clay Minerals, 22, 1987. 225-232.

CORMA, A.; PARIENTE, J.; SORIA, J. Physico- Chemical Characterization of Cu2+ Exchanged Sepiolite. Clay Minerals, 20, 1985. 467-475.

DELEGARD, C. H.; BARNEY, G. S. Fixation of radioactive waste by reactions with clays: Progress report. Washington: Atlantic Richfield Hanford Company Richland, 1975.

DELKASH, M.; BAKHSHAYESH, B. E.; KAZEMIAN, H. Using zeolitic adsorbents to cleanup special wastewater streams: A review. Microporous and Mesoporous Materials, 214, 2015. 224-241.

DIAS, I. et al. Microscopia electrónica de transmisión (TEM) y de barrido (MEV). In: FARALDOS, M.; GOBERNA, C. Tecnicas de análisis y caracterización de materiales. [S.I.]: Consejo Superior de Inverstigaciones Científicas (CSIC), 2002. p. 455-490.

DLOUHY, Z. Disposal of Radioactive Wastes. New York: Elsevier, 1982.

DRITS, V. A.; SOKOLOVA, G. V. Structure of palygorskite. Soviet Physics Crystallography, 16, 1971. 183-185.

DUCA, M.; GABORIAUDA, F.; THOMA, F. Sensitivity of the acid-base properties of clays to the methods of preparation and measurement: 1. Literature review. Journal of Colloid and Interface Science, v. 289, n. 1, p. 139-147, 2005.

EROGLU, H.; YAPICI, S.; NUHOGLU, C.; VAROGLU., E.. Bisorption of Ga-67 radionuclides from aqueous solutions into waste pomace of an olive oil factory. J Hazard Mater, 172, n. 2-3, 2009. 729738.

ESTEBAN-CUBILLO, A. Obtención de nanopartículas metálicas soportadas o embebidas en matrices oxídicas: alúmina - sepiolita. Tese. Universidad Autónoma de Madrid. [S.I.]. 2007.

ESTEBAN-CUBILLO, A.; PINA-ZAPARDIEL, R.; MOYA, J. S.; BARBA, M.; PECHARROMÁN, C.. The role of magnesium on the stability of crystalline sepiolite structure. Journal of the European Ceramic Society, 28, 2008. 1763-1768.

EWINGS, G. Métodos instrumentais de analise química. São Paulo: Edgard Blucher, v. 1, 1972.

FAN, Q.; SHAO, D.; LU, Y.; WU, W.; WANG, X.. Effect of pH, ionic strength, temperature and humic substances on the sorption of $\mathrm{Ni}(\mathrm{II})$ to Na-attapulgite. Chemical Engineering Journal, 150, 2009. 188-195.

FERNÁNDEZ, A.; TIMÓN, V.; CUBERO, J.; SÁNCHEZ-LEDESMA, D.; GUTIÉRREZ-NEBOT, L.; MARTÍNEZ, J.; ROMERO, C.; LABAJO, M.; MELÓN, A.; BARRIOS, I.. Comprehensive Characterization of Palygorskite from Torrejón el Rubio (Spain) Based on Experimental Techniques and Theoretical DFT Studies. CIEMAT. Madrid. 2013.

FERREIRA, V.; ALEIXO, B. L.; ULHOA, B. A.; CUCCIA, V. Rejeitos radioativos de baixo e médio nível: levantamento da variação de volume Armazenado e disposto. Revista Brasileira de Ciências Ambientais, Belo Horizonte, n. 24, p. 27- 36, 2012. 
FOIS, E.; GAMBA, A.; TILOCCA, A. On the unusual stability of Maya blue paint: molecular dynamics simulations. Microporous and Mesoporous Materials, 57, 2003. 263-272.

FRINI-SRASRA, N.; SRASRA, E. Acid treatment of south Tunisian palygorskite: Removal of Cd (II) from aqueous and phosphoric acid solutions. Desalination, 250, 2010. 26-34.

FROST, R.; MENDELOVICI, E. Modification of fibrous silicates surfaces with organic derivatives: An infrared spectroscopic study. Journal of Colloid and Interface Science, 294, n. 1, 2006. 47-52.

GALAN, E. Propierties and applications of palygorskite-sepiolite clays. Clay minerals, 31, 1996. 443-453.

GALAN, E.; APARICIO, P. The Identification and Nomenclature of Sepiolite and Palygorskite (A Historical Perspective). In: PASBAKHSH, P.; CHURCHMAN, G. J. Natural Mineral Nanotubes. Propierties and Applications. Canadá: Apple Academic Press, Inc, 2015. Cap. 3, p. 69-85.

GALAN, E.; SINGER, A. Developments in Palygorskite-Sepiolite Research: A new outlook on these Nanomaterials. Developments in Clay Science. [S.I.]: Elsevier, 2011.

GALUNIN, E.; ALBA, M. D.; SANTOS, M. J.; ABRÃO, T.; VIDAL, M.. Examination of competitive lanthanide sorption onto smectites and its significance in the management of radioactive waste. Journal of Hazardous Materials, 186, 2011. 1930-1941.

GANTENBEIN, D.; SCHOELKOPF, J.; MATTHEWS, P.; PATRICK, B.; A., GANE. Determining the size distribution-defined aspect ratio of rod-like particles. Applied Clay Science, 53, n. 4, 2011. 538543.

GASKOVA, O. L.; BUKATY, M. B. Sorption of different cations onto clay minerals: Modelling approach with ion exchange and surface complexation. Physics and Chemistry of the Earth, 33, 2008. 1050-1055.

GOMES, C. Argilas e o que são e para que servem. Fundação Calouste Gulbenkian. Lisboa. 1988.

GONZÁLEZ, F.; PESQUERA, C.; BENITO, I. A study by thermal analysis of the reversible folding in palygorskite unde vacuum thermal treatment. Thermochimica Acta, 223, 1993. 83-91.

GORE, D.; SNAPE, I. $50 \mathrm{kGy}$ of gamma irradiation does not affect the leachability of mineral soils and sediments. Powder Diffraction, 29, n. 51, 2014. 540-546.

GÜVEN, N. The coordination of aluminium ions in the palygorskite structure. Clay and Clay Mineral, 40, 1992. 457-461.

HE, M.; ZHU, Y.; YANG, Y; HAN, B.; ZHANG, Y.. Adsorption of cobalt(II) ions from aqueous solutions by palygorskite. Applied Clay Science, 54, 2011. 292-296.

HIROMOTO, G. et al. Introdução à gestãode rejeitos radioativos. São Paulo: Instituto de Pesquisas Energéticas e Nucleares, Departamento de Rejeitos, 1999.

HUO, C.; YANG, H. Attachment of nickel oxide nanoparticles on the surface of palygorskite nanofibers. Journal of Colloid and Interface Science, 384, 2012. 55-60.

HUSSIN, F.; AROUA, M. K.; DAUD, W. M. A. W. Textural characteristics, surface chemistry and activation of bleaching earth: A review. Chemical Engineering Journal, 170, 2011, 90-106.

IAEA. Handling and Processing of Radioactive Waste from Nuclear Applications. Vienna: [s.n.], v. TRS-402, 2001. 
IAEA. Applications of ion exchange processes for the treatment of radioactive waste and management of spent ion exchangers. Vienaa: [s.n.], v. TRS-408, 2002.

IAEA. Nuclear Technology Review 2013. Vienna: International Atomic Energy Agency, 2013.

IUPAC. Compendium of Chemical Terminology. Gold Book. 2.3.3. ed. [S.I.]: [s.n.], 2014.

JI, J. et al. Rapid identification of dolomite using a Fourier Transform Infrared Spectrophotometer (FTIR): A fast method for identifying Heinrich events in IODP Site U1308. Marine Geology, 258, 2009. 60-68.

JIANG, J. et al. Synthesis of zeolite A from palygorskite via acid activation. Applied Clay Science, 55, 2002. 108-113.

JONES, B. F.; GALAN, E. Sepiolite and palygorskite. In: AMERICA, M. S. O. Hydrous Phyllosilicates (Exclusive of Micas). Reviews in Mineralogy. Washington, DC: [s.n.], v. 19, 1988. p. 631-674.

JONSTON, C. T. Sorption of organic compounds on clay mineral: A surface functional group approach. The Clay Mineral Society: CMS Workshop Lectures. [S.I.]: [s.n.]. 1996. p. 2-44.

KOMARNENI, S.; ROY, D. M. EFFECT OF LAYER CHARGE AND HEAT TREATMENT ON Cs FIXATION BY LAYER SILICATE MINERALS. J. inorg, nucl. Chem., 40, 1978. 893-896.

KRUG, F.; NÓBREGA, J.; OlIVEIRA, P. Espectrometría de Absorção Atomica- Parte 1. Fundamentos e atomização com chama. São Paulo: [s.n.], 2004.

LAGER, G.; JORGENSEN, J.; ROTELLA, F. Crystal Structure and Thermal Expansion alfa- SiO, at Low Temperatures. In: FABOR, J. Neutron Scattering. [S.I.]: [s.n.], 1982. p. 75-77.

LAZAREVIĆ, S.; JANKOVIĆ-ČASTVAN, I.; JOVANOVIĆ, D.; , SLOBODAN, M.; JANAĆKOVIĆ, D.; PETROVIĆ, R. Adsorption of $\mathrm{Pb} 2+, \mathrm{Cd} 2+$ and $\mathrm{Sr} 2+$ ions onto natural and acid-activated sepiolites. Applied Clay Science, 37, 2007. 47-57.

LEE, K. Y. et al. Novel application of nanozeolite for radioactive cesium removal from high-salt wastewater. Water Research, 2016.

LIMA, E.; BOSH, P.; BULBULIAN, S. Immobilization of Cobalt in collapsed non-irradiated and girradiated X zeolites. Applied Radiation and Isótopes, 65, 2007. 259-265.

LIU, Y.; WANG, W.; WANG, A. Effect of dry grinding on the microstructure of palygorskite and adsorption efficiency for methylene blue. Powder Technology, 225, 2012. 124-129.

LOPEZ, A.; MARQUEZ, C. Espectroscopia Infrarroja (IR). In: FARALDOS, M.; GOBERNA, C. Tecnicas de analises y caracterizacion de materiales. Consejo Superior de Investigaciones Cientificas (CSIC). ed. Madrid: [s.n.], 2002. p. 153-188.

LOPEZ-GALINDO, A.; VISERAS, C.; CEREZO, P. Compositional, technical and safety specifications of clays to be used na pharmaceutical and cosmetic products. Applied Clay Science, 36, 2007. 5163.

LUZ, A.; ALMEIDA, S. Argila- Atapulgita e sepiolita. Rochas e Minerais Industriais. CETEM, n. 10, p. 223-238, 2008.

MANGONI, A. Materiais híbridos baseados em argilas catiônicas e espécies com potencial terapêuticos. Dissertação de mestrado. Universidade de São Paulo. [S.I.]. 2014. 
MC BRIDE, M. B. Environmental Chemistry of Soils. New York: Oxford University Press, 1994.

MENDELOVICI, E. Infrared study of attapulgite and $\mathrm{HCl}$ treated attapulgite. Clays and Clay Minerals, 21, 1973. 115-119.

MIDDEA, A.; FERNANDES, T.; NEUMANN, R; GOMES, O.; SPINELLI, L. Evaluation of Fe(III) adsorption onto palygorskite surfaces. Applied Surface Science, 282, 2013. 253-258.

MISER, D.; SWINNEA, J.; STEINFINK, H. TEM observations and X-ray cristal-structure refinement of a twinned dolomite with a modulated microstruture. Americam Mineral, v. 72, p. 139-169, 1987.

MOLLER, T.; BESTAOUI, N.; WIERZBICKI, M.; ADAMS, T.; CLEARFIELD, A. Separation of lanthanum, hafnium, barium and radiotracers yttrium- 88 and barium-133 using crystalline zirconium phosphate and phosphonate compounds as prospective materials for a Ra-223 radioisotope generator. Applied Radiation and Isotopes, 69, 2011. 947-954.

MOTT, B. Clay Minerals - An introduction. Catalysis Today, 2, 1988. 199-208.

MURRAY, H. Traditional and new applications for kaolin, smectite, and palygorskite: a general overview. Applied Clay Science, 17, n. 5-6, 2000. 207-221.

MYRIAM, M.; SUÁREZ-BARRIOS, M.; MARTIN-POZAS, J. M. Structural and textural modifications of palygorskite and sepiolite under acid treatment. Clays and Clay Minerals, 46, 1998. 225-231.

NAGY, N. M.; KÓNYA, J.; WAZELISCHEN-KUN, G. The adsorption and desorption of carrier-free radioactive isotopes on clay minerals and Hungarian soils. A: Physicochemical and Engineering Aspects, 152, 1999. 245-250.

NETO, J.; ALMEIDA, M.; CARVALHO, R. Atapulgita do Piauí para a Indústria Farmacêutica. CETEM - Tecnologia Mineral, v. 64, 1993.

NIKIFOROVA, A.; TASKAEVA, I.; KUKEWA, R.; SLAVCHEV., B. Determination of $63 \mathrm{Ni}$ in low-level liquid radioactive waste. Advances in Liquid Scintillation Spectrometry, 2005. 311-321.

NORDBERG, G.; FOWLER, B.; NORDBERG, M.; FRIBERG, L. Handbook on the toxicology of metals. 3. ed. Amsterdam: Elsavier, 2007.

OJOVAN, M.; LEE, W. An Introduction to Nuclear Waste Immobilisation. $2^{\circ}$. ed. [S.I.]: Elsevier, 2014.

OLIVEIRA, R. N; ACCHAR, W; SOARES, G. D.; BARRETO, L. S. The increase of surface area of a Brazilian palygorskite clay activated with sulfuric acid solutions using a factorial design. Material Research, 16, n. 4, 2013. 924-928.

PASBAKHSH, P.; CHURCHMAN, J. Natural Mineral Nanotubes: Propierties and Applications. Canada: Apple Academic Press, Inc, v. 1, 2015.

PAVEL, C. C.; POPA, K. Investigations on the ion exchange process of $\mathrm{Cs}+$ and $\mathrm{Sr} 2+$ cations by ETS materials. Chemical Engineering Journal, 245, 2014. 288-294.

PAVLIDOU, S.; PAPASPYRIDES, C. D. A review on polymer-layered silicate nanocomposites. Progress in Polymer Science, 33, n. 12, 2008. 1119-1198.

PETERSON, J.; MACDONELL, M.; HAROUN, L.; MONETTE, F. Radiological and Chemical Fact Sheets to Support Health Risk Analyses for Contaminated Areas. [S.I.]: Argonne National Laboratory Environmental Science Division, 2007. 
PINA-ZARPADIEL, R. Obtencion de Nanoparticulas oxídicas, metálicas y aleaciones en sistemas jerarquicos en base sepiolita para aplicaciones multifuncionales. Tese de doutorado - Universidad Autónoma de Madrid. Madrid. 2011.

POTGIETER, J.; POTGIETER-VERMAAK, S.; KALIBANTONGA, P. Heavy metals removal from solution by palygorskite clay. Minerals Engineering, 19, n. 5, 2006. 463-470.

PREISINGER, A. Sepiolite and related compounds: its stability and application. Clays and Clay Minerals, 10, 1963. 365-371.

PUSHKAREVA, R.; KALINICHENKO, E.; LYTOVCHENKO, A.; PUSHKAREV, A.; KADOCHNIKOV, V.; PLASTYNINA, M. Irradiation effect on physico-chemical properties of clay minerals. Applied Clay Science, 21, 2002. 117-123.

PYRZYNSKA, K.; BYSTRZEJEWSKI, M. Comparative study of heavy metal ions sorption onto activated carbon, carbon nanotubes, and carbon-encapsulated magnetic nanoparticles. Colloids and Surfaces A: Physicochemical and Engineering Aspects, 362, n. 1-3, 2010. 102-109.

QIU, Y.; YU, S.; SONG, Y.; WANG, Q.; ZHONGA, S.; TIAN, W. Investigation of solution chemistry effects on sorption behavior of $\operatorname{Sr}($ II) on sepiolite fibers. Journal of Molecular Liquids, 180, 2013. 244-251.

RAHMAN, R.; IBRAHIUM, H.; HUNG, Y. Liquid Radioactive Wastes Treatment: A Review. Water, 3 , n. 2, 2011. 551-565.

RASHID, F.; GHAFFAR, A. Sorption of radiocesium from liquid radioactive waste on clay and immobilization by baking the clay at elevated temperature. Radiochimica Acta, 99, n. 1, 2010. 3741

REED, J. Principies of Ceramics Processing. 2. ed. New York: John Wiley \& Sons, v. 1, 1995.

ROBINSON, A. Ion-Exchange Minerals and Disposal of Radioactive Wastes-A survey of literature. Geological survey water, 1962. 1-140.

RUIZ-HITZKY, E.; ARANDA, P.; SERRATOSA, J. M. Handbook of Layered Materials. New York: [s.n.], 2004.

SANCHEZ-DELRIO, M.; MARTINETTO, P.; REYES-VALERIO, C.; DOORYHEE, E.; SUAREZ, M. Synthesis and acid resistance of maya blue pigment. Archaeometry, 48, n. 1, 2006. 115-130.

SCHOONHEYDT, R. A.; JONSTON, C. T. Surface and interface chemistry of clay minerals. In: E, G.; J, S. Handbook of Clay Science. [S.I.]: [s.n.], v. 1, 2006. p. 87-113.

SERRATOSA, J. M. Surface properties of fibrous clay minerals (palygorskite and sepiolite). Developments in Sedimentology. International Clay Conference. Oxford: [s.n.]. 1979. p. 99-109.

SHAH, L.; SILVA-VALENZUELA, M.; EHSAN, M; VALENZUELA-DÍAZ, F.; KHATTAK, N. Characterization of Pakistani purified bentonite suitable for possible pharmaceutical application. Applied Clay Science, 83, 2013. 50-55.

SHEIKHHOSSEINI, A.; SHIRVANI, M.; SHARIATMADARI, H.; ZVOMUYA, F.; NAJAFIC, B. Kinetics and thermodynamics of nickel sorption to calcium-palygorskite and calcium-sepiolite: A batch study. Geoderma, 217-218, 2014. 111-117.

SILVA, A. C. Caracterização de atapulgita visando aplicação para reforço de materiais poliméricos. Dissertação de Mestrado. Universidade Federal do Rio Grande do Norte. Natal. 2011. 
SINHA, P.; KRISHNASAMY, V. Fixation of Caesium, Strontium and Thorium lons in Commercial Synthetic Zeolite Matrices by Thermal Treatment. Journal of Nuclear Science and Technology, 33, n. 4, 1996. 330-340.

SOUSA-REIS, A.; TEMBA, S.; KASTNER, F.; MONTEIRO, P. Radiochemical Separation of Nickel for $59 \mathrm{Ni}$ and $63 \mathrm{Ni}$ Activity Determination in Nuclear Waste Samples. In: CHANG, S. H. Nuclear Power Plants. [S.I.]: [s.n.], 2012.

SOUZA-SANTOS, P. Ciência e Tecnologia de Argilas. [S.I.]: Edgard Blücher, v. 1, 1989.

SPOSITO, G. The chemistry of soils. New York: Oxford University Press, 1989.

STAFIEJ, A.; PYRZYNSKA, K. Adsorption of heavy metal ions with carbon nanotubes. Separation and Purification Technology, 58, n. 1, 2007. 49-52.

STOYLOV, S.; PETKANCHIN, I. Transient electric light scattering III. Investigation of the stability of palygorksite colloid solutions. Journal Colloid Interface Science, 40, 1972. 159-163.

STRAWN, G.; BOHN, L.; O'CONNOR, A. Soil Chemistry. 4. ed. Oxford: [s.n.], 2015.

SUÁREZ-BARRIOS, M.; GARCÍA-ROMERO, E.; SÁNCHEZ-DELRIO, M.; MATINETTO, P.; DOORYHÉE, E. The effect of the octahedral cations on the dimensions of the palygorskite cell. Clay Minerals, 42, 2007. 287-297.

SUÁREZ-BARRIOS, M.; GONZÁLES, L.; , VICENTE-RODRÍGUEZ, M.; MARTÍN-POZAS, J. Acid activation of a palygorskite with $\mathrm{HCl}$ : development of physico-chemical, textural and surface properties. Applied Clay Science, 10, 1995. 247-258.

SUÁREZ-BARRIOS, M.; GARCÍA-ROMERO, E. Variability of the surface properties of sepiolite. Applied Clay Science, 67-68, 2012. 72-82.

SUÁREZ-BARROS, M.; GARCÍA-ROMERO, E. FTIR spectroscopic study of palygorskite: Influence of the composition of the octahedral sheet. Applied Clay Science, 31, 2006. 154-163.

SYLVESTER, P.; CLEARFIELD, A.; DIAZ, R. J. Pillared montmorillonites: cesium-selective ionexchange materials. Sep. Sci. Technol., 34, 1999. 2293-2305.

THOMPSON, A.; GOYNE, K. Introduction to the sorption of chemical constituents in soils. [S.I.]: Nature Education Knowledge, 2012.

UTRACKI, L. A. Clay-Containing Polymeric Nanocomposites. [S.I.]: RAPRA Technology, 2004.

VIEIRA-COELHO, A. C.; SOUZA-SANTOS, P.; SANTOS, H. S. Special clays: chemically modified clays - a review. Quımica Nova, 30, n. 5, 2007. 1282-1294.

VILLA-ALFAGEME, M. et al. Uranium immobilization by FEBEX bentonite and steel barriers in hydrothermal conditions. Chemical Engineering Journal, 269, 2015. 279-287.

WANG, J.; WAN, Z. Treatment and disposal of spent radioactive ion-exchange resins produced in the nuclear industry. Progress in Nuclear Energy, 78, 2015. 47-55.

WANG, W.; CHEN, H.; WANG, A. Adsorption characteristics of Cd(II) from aqueous solution onto activated palygorskite. Separation and Purification Technology, 55, n. 2, 2007. 157-164.

WEBB, P. A.; ORR, C. Surface Area and Pore Structure by Gas Adsorption. In: WEBB, P. A.; ORR, C. Analytical Methods in Fine Particle Technology. [S.I.]: [s.n.], 1997. p. 53-91. 
XAVIER, K.; SILVA-FILHO, E. DA; SANTOS, M.; SANTOS, M. R.; LUZ, A. Caracterização mineralógica, morfológica e de superfície da atapulgita de Guadalupe-PI. Holos, v. 5, n. 28, p. 6070, 2012.

XAVIER, K; SANTOS, M. FERREIRA-DOS; M, R. CHAVES-SANTOSI; OLIVEIRA, R.; M, CARVALHO, J. OSAJIMA, E. DA SILVA-FILHO. Effects of acid treatment on the clay palygorskite: XRD, surface area, morphological and chemical composition. Material research, 17, n. 1, 2014. 38.

YAN, W.; LIU, D.; TAN, D.; PENG, Y.; CHEN, M.. FTIR spectroscopy study of the structure changes of palygorskite under heating. Spectrochimica Acta Part A: Molecular and Biomolecular Spectroscopy, 97, 2012. 1052-1057.

ZHANG, J.; WANG, Q.; CHEN, H.; WANG, A. XRF and nitrogen adsorption studies of acid-activated palygorskite. Clay Minerals, 45, n. 145, 2010. 145-156.

ZHAO, G.; LI, J.; X, REN; CHEN, C.; WANG, X. Few-layered graphene oxide nanosheets as superior sorbents for heavy metal ion pollution management. Environ Sci Technol., 45, 2011. 10454-10462.

ZHOU, C. H.; KEELING, J. Fundamental and applied research on clay minerals: From climate and environment to nanotechnology. Applied Clay Science, 74, 2013. 3-9. 